Universidade de SÃo PaUlo

Faculdade de Filosofia, Letras e Ciências Humanas

Departamento de Letras Clássicas e Vernáculas

Luciana NaVArRo de Assunção

UM ESTUDO DAS VOZES NO GÊNERO 'DECISÕES JudiCIAIS' EM DOCUMENTOS DO SÉCULO XIX 
Universidade de SÃo PaUlo

Faculdade de Filosofia, letras e Ciências Humanas

Departamento de Letras Clássicas e Vernáculas

LuCiana NaVArro de AssunÇão

\title{
UM ESTUDO DAS VOZES NO GÊNERO 'DECISÕES JudiCIAIS' EM DOCUMENTOS DO SÉCULO XIX
}

\begin{abstract}
Dissertação de Mestrado apresentada ao Departamento de Letras Clássicas e Vernáculas da Faculdade de Filosofia, Letras e Ciências Humanas da Universidade de São Paulo, como requisito parcial para a obtenção do título de Mestre, na área de Filologia e Língua Portuguesa.
\end{abstract}

Orientador: Prof. Dr. Gabriel Antunes de Araújo 
Dedico este trabalho aos meus companheiros de caminhada: meus amados pais, encorajando-me na luta diária; minhas irmãs, fortalecendo-me com suas semelhantes experiências; meu marido, amigo de longas datas e leal escudeiro; minhas anjinhas, inspirações do meu viver, dádivas concedidas dos céus. 


\section{Sumário}

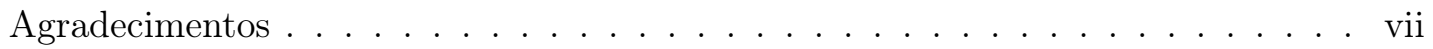

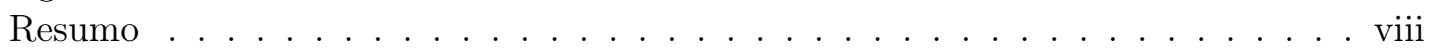

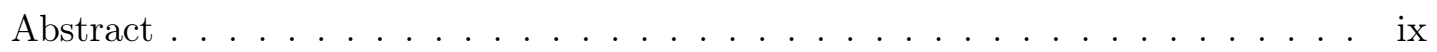

Lista de Abreviaturas . . . . . . . . . . . . . . . . . x

1 Introdução 1

2 Espaço Jurídico $\quad 6$

2.1 Introdução . . . . . . . . . . . . . . . . . . . . . . . 6

2.2 Reconstituindo o momento histórico: o Poder Judiciário Brasileiro no século

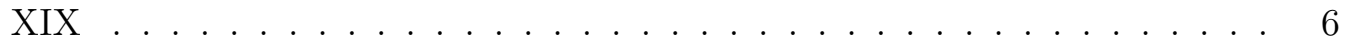

2.3 Aspectos da luta pela liberdade: a escravidão brasileira . . . . . . . . . . . 13

2.4 O pensamento jurídico-filosófico do século XIX . . . . . . . . . . . . 21

2.5 O processo judicial e seus atores . . . . . . . . . . . . . . . . . . 29

2.6 As decisões: definindo o gênero jurídico e sua estrutura . . . . . . . . . . . . 31

3 Fundamentação teórico-metodológica $\quad 40$

3.1 Introdução . . . . . . . . . . . . . . . . . . . . . . . . 4 40

3.2 A ciência filológica . . . . . . . . . . . . . . . . . . . . . . 40

3.3 Análise/Teoria Dialógica do Discurso . . . . . . . . . . . . . . . . . . . . 45

4 Apresentando a materialidade: reprodução fac-similar e leitura semi$\begin{array}{ll}\text { diplomática } & \mathbf{6 0}\end{array}$

4.1 Normas de transcrição . . . . . . . . . . . . . . . . . . . . . . . . . 60

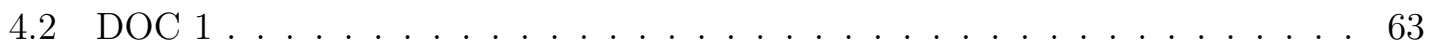

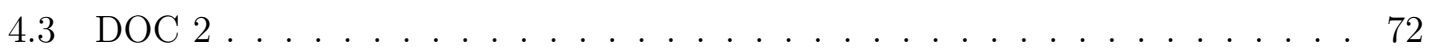

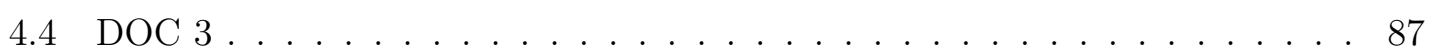

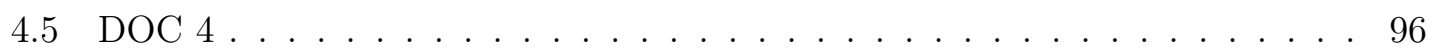

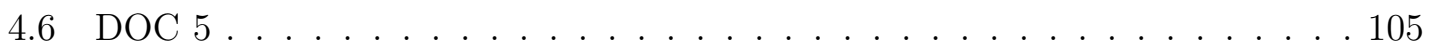

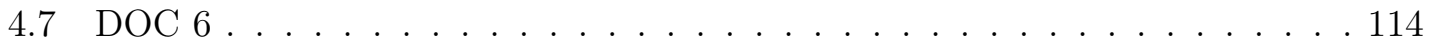

4.8 DOC $7 \ldots \ldots \ldots \ldots \ldots$

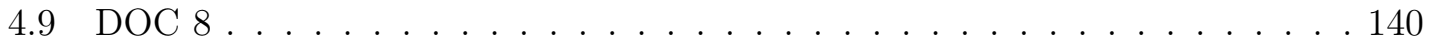

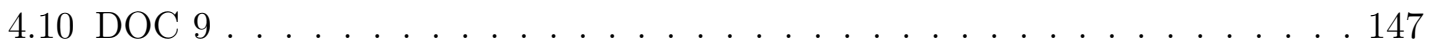

4.11 DOC $10 \ldots \ldots \ldots \ldots \ldots \ldots$

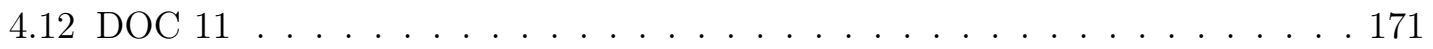

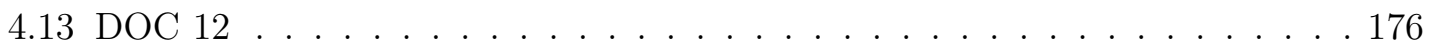

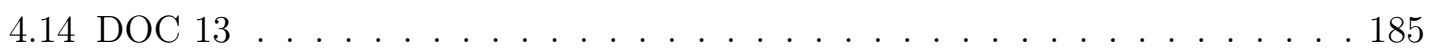

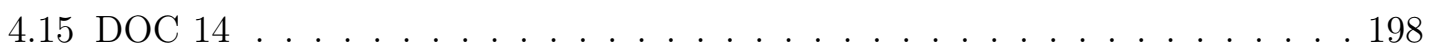

5 As vozes no discurso decisório $\quad 209$

5.1 Introdução . . . . . . . . . . . . . . . . . . . . . . . . . . 209

5.2 Análise e interpretação das decisões . . . . . . . . . . . . . . . . . . . . . 211 
$5.2 .1 \quad$ As outras presenças . . . . . . . . . . . . . . . . . 211

5.2.2 Em busca do sentido: as sentenças . . . . . . . . . . . . . . . . . 222

5.2 .2 .1 Sentenças D3S e D5S . . . . . . . . . . . . . . 224

5.2.2.2 Sentenças D1S, D7S, D9S, D11S e D13S . . . . . . . 232

5.2 .3 Em busca do sentido: os acórdãos . . . . . . . . . . . . . . . 248

5.2.3.1 Acórdãos D10A e D12A . . . . . . . . . . . . 258

5.2 .3 .2 Acórdão D14A . . . . . . . . . . . . . . . . 260

6 Considerações finais $\quad 262$

$\begin{array}{lll}7 & \text { Referências bibliográficas } & \mathbf{2 7 0}\end{array}$ 
"Há um tempo em que é preciso abandonar as roupas usadas, que já tem a forma do nosso corpo, e esquecer os nossos caminhos, que nos levam sempre aos mesmos lugares. É o tempo da travessia: e, se não ousarmos fazê-la, teremos ficado, para sempre, à margem de nós mesmos."

Fernando Pessoa 


\section{Agradecimentos}

Ao meu Condutor invisível e seus auxiliares, imprescindíveis para a existência nestas paragens.

Ao Professor Dr. Gabriel Antunes de Araújo, pela confiança depositada e pela orientação segura, que tornou possível a realização deste trabalho. Obrigada pela oportunidade concedida.

Um agradecimento especial às professsoras Rosineide de Melo e Ariani Bueno Sudatti. Rosi, que me apresentou "Bakhtin": apoio incondicional, amiga, fiel interlocutora e tutora de meus "devaneios"de pesquisa. Mais uma vez, muito obrigada! Professora Ariani, pela recepção carinhosa e interesse demonstrado em relação a minha pesquisa, direcionando-me e motivando-me a continuar a caminhada, concedendo-me de forma gratuita seus preciosos conhecimentos. Renovados agradecimentos a estas queridas professoras, que a confirmar todo o apoio e auxílio durante a execução do trabalho, reafirmaram esta tutela com a esclarecedora e contributiva participação nas Bancas de Qualificação e Defesa. 


\section{Resumo}

Neste trabalho, concentramo-nos em uma grande questão norteadora: a produção do discurso decisório, pelos representantes do Estado (juízes e desembargadores), no processo de subsunção da norma abstrata ao caso concreto, resulta em discursos imparciais, pautados exclusivamente na lei, ou estes discursos podem refletir decisões totalmente influenciadas e permeadas por outros discursos, representando as outras vozes que comporão conjuntamente estes discursos dialógicos? Para responder a esta questão, realizamos uma análise de sete sentenças judiciais e sete acórdãos, versantes sobre a situação jurídica de negros escravos. Como são decisões proferidas no século XIX, anos de 1873, 1874(3), 1875(3), 1876(4), 1877(3) e 1878, período de pré-vigência da Lei Áurea, encontram-se manuscritas. Por isso, utilizamos, para compreensão linguística dos manuscritos, da ciência filológica e de uma de suas formas de transcrição, a edição semidiplomática. Após a edição destas decisões, levantamos todos os aspectos do campo de produção deste gênero e do processo enunciativo, para então, posteriormente, detectarmos os recursos linguísticos e discursivos utilizados pelos magistrados em suas decisões, que revelaram como este juiz-autor de seu discurso- maneja as diversas vozes que os perpassam, as vozes dos personagens (autor, réu do processo, testemunhas), as vozes de outros julgamentos, outros tribunais ou a própria voz interior deste sujeito-autor-juiz, como uma singularidade. Com isto, objetivamos, debater o estatuto discursivo destas decisões judiciais e de suas constituição como gênero e como práxis discursiva dialógica, discussão esta amparada pelo arcabouço da teoria dialógica do discurso.

Palavras-chave: Manuscritos; Decisões Judiciais; Filologia; Teoria Dialógica do Discurso. 


\begin{abstract}
In this work, we concentrate on one major leading question: the decisive speech production by the representatives of the State (judges and high level court judges), the process of subsumption of the abstract norm to the concrete case, results on impartial speeches, guided only by the law or these speeches may reflect decisions totally permeated and influenced by other discourses, representing the other voices that compose together these dialogical discourses? To answer this question, we analyzed seven judicial judgment sentences and seven high level court judgments, about the legal status of slaves. As the decisions were made in the nineteenth century, years of 1873, 1874 (3), 1875 (3), 1876 (4), 1877 (3) and 1878, period of the Golden Law pre-term, they are handwritten. Therefore, we used, for linguistic understanding of the manuscripts, philological science and one of its forms of copying, the semidiplomatic edition. After editing these decisions, we raised all aspects of the production field of this gender and the enunciation process, and then, subsequently, detect the linguistic and discursive resources used by judges in their decisions, which showed how this Judge-author of their speech manages the several voices that permeate them, the characters' voices (author, accused of the case, witnesses), the voices of other judgments, other courts or their own interior voice within this subject-author-judge, as a singularity. With this, we intend to discuss the discursive policy (statute) of these decisions and their constitution as a genre and as a dialogical discursive praxis, such discussion supported by the theoretical framework of the dialogical theory of discourse.
\end{abstract}

Keywords: Manuscripts; Judgments; Philology; Dialogical Theory of Discourse. 


\section{Lista de Abreviaturas}
D1S Documento 1 Sentença
D2A Documento 2 Acórdão
D3S Documento 3 Sentença
D4A Documento 4 Acórdão
D5S Documento 5 Sentença
D6A Documento 6 Acórdão
D7S Documento 7 Sentença
D8A Documento 8 Acórdão
D9S Documento 9 Sentença
D10A Documento 10 Acórdão
D11S Documento 11 Sentença
D12A Documento 12 Acórdão
D13S Documento 13 Sentença
D14A Documento 14 Acórdão
STF Supremo Tribunal Federal
STJ Superior Tribunal de Justiça
TST Tribunal Superior do Trabalho
TSE Tribunal Superior Eleitoral 


\section{Capítulo 1}

\section{Introdução}

Neste trabalho, concentrar-nos-emos na seguinte questão: na produção do discurso decisório, os representantes do Estado (juízes e desembargadores), no processo de interpretação da norma abstrata, para solução do caso concreto, produzem discursos imparciais, pautados exclusivamente na lei, refletindo um processo mecânico de mera aplicação da lei ou estes discursos, mesmo constituindo decisões imparciais, poderão refletir discursos influenciados e permeados por outros, discursos estes representativos das outras vozes que comporão conjuntamente estes discursos dialógicos, denunciando assim o comprometimento ideológico do enunciador? Para responder a esta questão, realizaremos uma análise de sete sentenças judiciais e sete acórdãos, versantes sobre a situação jurídica de negros escravos, proferidas no século XIX, nos anos de 1873 (1 peça), 1874 (4 peças), 1875 (2 peças), 1876 (3 peças), 1877 (3 peças) e 1878 (1 peça), período de pré-vigência da Lei Áurea. Os documentos manuscritos foram coletados no Arquivo Público do Estado de São Paulo, que, por intermédio de um acordo com o Tribunal de Justiça do Estado de São Paulo, é o responsável pela preservação e armazenamento dos processos tramitados nos séculos XIX e XX.

Utilizaremos da via filológica como meio, em sua função transcendente, para leitura e edição dos documentos, e da teoria/análise dialógica do discurso, a fim de realizarmos um 
estudo da linguagem jurídica e de sua manifestação nas decisões judiciais analisadas, contextualizando historicamente os discursos abordados, revelando características do Direito daquela época e da situação do escravo na sociedade. Serão apresentadas edições semidiplomáticas, a fim de se conservar a linguagem dos documentos. Após a leitura destas decisões, levantaremos os aspectos do campo de produção do gênero 'decisão judicial' e do processo enunciativo, para, posteriormente, detectar os recursos linguísticos e discursivos utilizados pelos magistrados em suas decisões e revelar como os autores manejavam as diversas vozes que as perpassam, as vozes dos personagens (autor, réu do processo, testemunhas), as vozes de outros julgamentos, outros tribunais ou a própria voz deste sujeito-autor-juiz, como uma singularidade. Com isto, nosso objetivo é debater, no Brasil Imperial dos anos que antecederam a libertação dos escravos, o estatuto discursivo da sentença judicial e de sua constituição como gênero e como práxis discursiva dialógica, discussão esta amparada pelo arcabouço da teoria dialógica do discurso.

As decisões judiciais constituem o ponto ápice de um processo judicial. Representa o dever fazer/ser, que será determinado por pessoa (juiz) revestida da vontade do Estado. Além do que, as decisões exteriorizam o dizer da lei, as tornam efetivas e práticas. Portanto, as decisões judiciais são o cume da expressão da linguagem jurídica. A decisão é o documento mais importante elaborado pelo magistrado, porque traz uma definição para o conflito e pode mudar substancialmente a vida daqueles personagens envolvidos. Por isso, sua linguagem tem grande relevância e expressa cabalmente o poder deste autor-juiz, que por consequência, como representante do Estado, deve fazer valer a lei diante de um caso concreto. Importante esclarecer que o referido gênero (decisão judicial) foi escolhido considerando seu importante status dentre todos os outros gêneros que circulam na esfera jurídica. Outra questão muito relevante para a escolha deste corpus foi a nossa vivência na 
advocacia. Como representante de uma das partes envolvidas nestes litígios, sempre estivemos muito perto destes discursos decisórios, sendo, muitas vezes, surpreendidos por sua linguagem e conteúdo. Não raro quando nos deparávamos com decisões inesperadas, indissociadas daquelas proferidas pela maioria dos juízes daquele tribunal, ou seja, contrária à posição majoritária e despreendida de justificativa coerente, demonstrando, sensivelmente, a ocorrência de outras razões motivadoras, a embasar aqueles discursos. Este fato incitounos a procurar explicações extrajurídicas para estes julgados divergentes, quando deveriam ser iguais, ao passo que reclamavam a aplicação da mesma lei.

Assim chegamos à questão que norteia estes estudos, já anunciada inicialmente. Ressalta-se que o termo 'ideologia' aqui será entendido como a proposta de Bakhtin e o Círculo, tanto como a ideologia oficial relativamente estável, como pela ideologia do cotidiano, como acontecimento instável e determinado pela praxis; ambas formando um contexto ideológico completo e único, determinando a linguagem, sem perder de vista o processo global de produção e reprodução social (MIOTELLO, 2008).

Salta à vista, então, a dupla importância desta pesquisa para a comunidade: como importância primeira a conservação, difusão e transmissão de documentos jurídicos do século XIX, possibilitando outros estudos; como segunda, a resposta a inquietações, vivenciadas como profissional da advocacia, compartilhadas por qualquer profissional atuante da advocacia, que se vê órfão de explicações jurídicas para decisões em processos que atuam.

O percurso metodológico, como já explicitado, partirá da leitura e transcrição dos documentos para a análise do discurso, transportado, neste momento, para o interior de alguns conceitos propostos por Bakhtin e o Círculo. Sendo fiel à própria metodologia bakhtiniana, esta análise passará pelo levantamento de toda a práxis, do processo de enunciação, dos contextos histórico, jurídico e social. Segundo Freitas (2008), o Direito só pode ser imaginado em função do homem em sociedade, também sendo impossível pensá-lo sem 
sua linguagem. Por isso, é imprescindível investigar as relações entre Linguagem, práxis social e Direito para melhor compreensão dos múltiplos fatores históricos que determinam como se dá o acesso à Lei em nossa sociedade e quais os fundamentos das decisões judiciais nos casos concretos em que, os cidadãos comuns, sobretudo das classes marginalizadas, buscam a prestação jurisdicional. Ao nos voltarmos às decisões do nosso corpus, notamos que são discursos do século XIX, construídos sob a égide da visão positivista do direito. Na sociedade moderna, neste sentido, após a Revolução Francesa, a codificação do Direito representou o desenvolvimento extremo do racionalismo iluminista: a existência de normas descobertas pela razão fez surgir também a exigência de organizá-las mediante um sistema lógico, escrito e emanado do Estado. Assim, com o surgimento do Estado moderno, o Poder Judiciário afirmou-se como a esfera estatal competente para a resolução dos conflitos sociais decorrentes da violação das normas jurídicas. Para tanto, os juízes togados, fazendo valer as normas positivadas, produzem decisões, exteriorizadas por meio de uma linguagem escrita, altamente formalizadas e com características próprias (carreada por palavras técnicas, latinismos e expressões conhecidas apenas pelo grupo de usuários que compõe a comunidade semiótica que opera o Direito). Essa decisão se dá a conhecer publicamente através de um texto denominado sentença judicial, em primeiro grau, e acórdão, quando advém de juízes desembargadores que compõem o Tribunal Superior (os Tribunais da Relação na época). São alguns dentre os tantos outros gêneros discursivos que circulam na esfera jurídica. Desta forma, é como discurso, ou seja, como manifestação verbal situada no solo concreto da vida social, impregnada de valores de uma determinada realidade histórica, que se encaminha este estudo das decisões judiciais.

O trabalho está dividido da seguinte forma: no capítulo 1, temos essa introdução, com a descrição dos caminhos da pesquisa, sua justificativa e percursos teóricos. No capítulo 2, teremos a formação do espaço jurídico no século XIX, com a reconstituição do momento 
histórico, filosófico e apresentação das especificidades jurídicas do gênero a ser analisado. As teorias que norteiam o estudo vêm explicitadas no capítulo 3, com um levantamento bibliográfico acerca dos principais temas incidentes no estudo do corpus. Antes da análise, no capítulo 4, apresentamos os documentos, em reproduções fac-similares e a respectiva edição semidiplomática, para que, no capítulo seguinte, de número 5 , possamos realizar a união da teoria com a prática, ou seja, a partir dos estudos teóricos, apresentar a análise dos documentos e uma interpretação dos resultados. E, finalmente, a conclusão da pesquisa, com as considerações finais no capítulo 6 , momento em que fazemos conexão de todos os capítulos e dispomos o resultado da pesquisa. 


\section{Capítulo 2}

\section{Espaço Jurídico}

\subsection{Introdução}

Nesse capítulo, pretendemos contextualizar a produção dos discursos, formando o panorama do espaço jurídico no século XIX. Para tanto, na seção 2.2, reconstituiremos o momento histórico, na seção 2.3, traremos as nuances da escravidão brasileira; a seção 2.4 mostrará o restabelecimento do paradigma filosófico que norteou a produção das decisões judicias foco deste trabalho, para, então, nas seções 2.5 e 2.6, fecharmos esta contextualização com elementos jurídicos, apresentando as especificidades do gênero a ser analisado.

\subsection{Reconstituindo o momento histórico: o Poder Judiciário Brasileiro no século XIX}

As decisões judiciais aqui analisadas, advindas do Tribunal de Justiça de São Paulo, em primeiro e segundo grau de jurisdição, versam sobre um tema único: a liberdade. Desta forma, o objeto destas ações são pedidos de liberdade, tendo como autores escravos, representados pelos curadores ${ }^{1}$ e como réus os senhores ou possuidores destes escravos. Estes

\footnotetext{
${ }^{1}$ Os escravos não eram considerados pessoas capazes, com autonomia de atuarem por si em juízo.
} Por isso, nomeavam curadores, tal como para as pessoas menores de idade. 
autores-escravos encontravam-se, na maioria dos casos, fugidos, porque entendiam não poderem mais continuar na condição de escravo, em virtude de terem sido doados como livres a seus donatários, ou por terem nascidos de ventre livre, ou ainda por terem sido "importados"para o Brasil depois da promulgação da lei de proibição do tráfico negreiro.

Quando ainda colônia recém-descoberta, o Brasil contava com uma organização judiciária e arcobouço de leis totalmente trasladadas de Portugal. Segundo Lopes (2002), ao mesmo tempo que envia para o Brasil dezenas de degregados para aqui viverem livremente, Portugal também transplanta o arcabouço institucional que vigorava em Lisboa. Assim, tínhamos a seguinte estrutura: na base estavam os juízes municipais ou ordinários, no topo o rei, como poder supremo, representado pelo seu tribunal superior, e entre eles uma espécie de justiça dos donatários e governadores e a justiça dos capitães, exercida pelos ouvidores (LOPES, 2002). Uma estrutura que inicia com um juiz de vintena², para localidades com poucos habitantes (até vinte), cuja responsabilidade se restringia a ordenar prisões, ao passo que os julgamentos eram de responsabilidade dos juízes ordinários. Nas causas cíveis ${ }^{3}$, poderiam solucionar controvérsias que não ultrapassassem 100 réis em povoações com menos de 50 moradores, e o máximo de 400 réis em povoados com mais de 200 habitantes. Tinham uma jurisdição limitada, cabendo aos juízes ordinários o julgamento das causas que fugiam à sua alçada.

Com o estabelecimento das capitanias hereditárias, cria-se também a figura do ouvidor da capitania, que seria responsável pelo julgamento das apelações (recursos) e em confirmar ou não a lista de juízes ordinários, eleitos pelo povo4. Com o fracasso das capitanias, o rei

\footnotetext{
${ }^{2}$ Juiz de vintena - No Direito português, era aquele eleito pelas câmaras municipais na proporção de um para cada vinte vizinhos, com competência para julgar questões de pequeno valor (SANTOS, 2001:135).

${ }^{3}$ Cível - (Lat. civilis.) Adj. 2g. Relativo ao cidadão e às relações dos cidadãos entre si, reguladas por normas do Direito Civil (SANTOS, 2001:50).

${ }^{4}$ Também chamados de Juízes da Terra, eram "eleitos pela comunidade, não sendo letrados, e apreciavam as causas em que se aplicavam os forais, isto é, o direito
} 
D. João III, com a edição do regimento de 25 de setembro de 1548, implanta o Governo

Geral, nomeando Tomé de Souza como primeiro Governador- geral e estabelecendo como sede a capitania da Bahia. Ele seria o principal representante do rei no Brasil, e o seu poder superava o dos donatários das capitanias. Esta limitação ao poder dos donatários continua com a indicação, pelo governador-geral, de um ouvidor geral ${ }^{5}$, Pero Borges, que até então era desembargador da Casa de Suplicação (órgão supremo de Portugal). Este ouvidorgeral era um 'chefe' dos ouvidores das comarcas, ficando responsável pelo julgamento das apelações, ou seja, em rever as decisões dos juízes das localidades. Assim:

(...) o ouvidor recebia recursos vindos de ouvidores de comarca, mas conhecia por ação nova, como jurisdição originária, conflitos que se dessem a uma distância de dez léguas de sua sede ou estada. Como podiam (e deviam) viajar para exercer seu poder inspetivo, sua jurisdição conflitava muitas vezes com a jurisdição ordinária das câmaras. De suas decisões podiam recorrer à Casa de Suplicação em Lisboa. Ao lado do ouvidor vinha o séquito de oficiais menores: escrivão para lavratura dos atos (autos) do processo, tabelião (para redação de documentos como notário), meirinhos (oficiais de diligências), eventualmente os inquiridores (cuja função era tomar depoimentos das testemunhas e inquiri-las), etc. (LOPES, 2002:264).

local, e cuja jurisdição era simbolizada pelo bastão vermelho que empunhavam (2 por cidade)". (CEZÁRIO, 2010. Disponível em Disponível em http://www.ambitojuridico.com.br/site/index.php?n_link=revista_artigos_leitura\&artigo_id $=7088 . \quad$ Acesso em $03 / 05 / 2012$.

${ }^{5}$ A expedição de Martim Afonso de Souza dá as bases para o estabelecimento das capitanias hereditárias. Com elas, a colônia amplia o sistema jurídico, agregando a figura do ouvidor da capitania. Junto com o Governador-Geral veio o Desembargador Pero Borges, que desempenhou a função de administrador da Justiça, no cargo de Ouvidor-Geral. Cada capitania tinha um Ouvidor da Comarca, que solucionava as pendengas jurídicas nas vilas. Caso alguém se sentisse prejudicado com alguma decisão do Ouvidor da Comarca, poderia recorrer ao OuvidorGeral, que ficava na Bahia (CEZÁRIO, 2010. Disponível em Disponível em http://www.ambitojuridico.com.br/site/index.php?n_link=revista_artigos_leitura\&artigo_id $=7088 . \quad$ Acesso em $03 / 05 / 2012$. 
A administração da Justiça, nesta segunda fase do período colonial, a dos Governadores-gerais, atendeu a necessidade de centralização do poder na colônia, aumentando o controle da Coroa por intermédio de seus representantes, que possuíam um poder que superava o dos donatários das capitanias. Continuava Portugal servindo-se de seu arcabouço legislativo, as Ordenações, para aqui imperar. Segundo Lopes (2002), as Ordenações Filipinas (editadas por Portugal em 1603 em substituição as Ordenações Afonsinas) vigeram por todo o período colonial brasileiro, de modo que a "primeira instância"da Justiça ${ }^{6}$ era formada por ouvidores-gerais, corregedores, ouvidores de comarca, provedores, juízes de fora, juízes ordinários, juízes de vintena (correspondentes ao juiz de paz), juízes de órfãos, almotacés, alcaides e vereadores. O juiz de fora ${ }^{7}$ era nomeado para residir em determinados lugares durante certo tempo (com a chegada do juiz de fora cessava a jurisdição do juiz ordinário), bem como se exigia que fosse letrado e entendido. De acordo com Ferreira (1952), na vila que houvesse mais de quatrocentos vizinhos (famílias) deveria existir o juiz de órfãos. Ele deveria ter mais de trinta anos, agir com grande diligência e cuidado, saber quantos órfãos havia em cada cidade, vila ou lugar em que fosse juiz, e fazê-los todos escrever em um livro ao escrivão desse ofício, declarando o nome e de cujo filho é, idade, onde vive, com quem e quem é o tutor. O juiz das vintenas, por sua vez, atuava nas cidades afastadas e poderia ser escolhido pelo juiz da jurisdição mais próxima, substituindo o juiz ordinário e realizando as atribuições de juiz de paz. O amotacés tinha a seu cargo a administração dos mercados, a distribuição dos gêneros

\footnotetext{
${ }^{6}$ Configuração da hierarquia do Poder Judiciário atual: a primeira instância, onde, em geral, começam as ações, é composta pelo juízo de direito de cada comarca, pelo juízo federal, eleitoral e do trabalho. A segunda instância, onde são julgados recursos, é formada pelos tribunais de Justiça e de Alçada, e pelos tribunais regionais federais, eleitorais e do trabalho. A terceira instância são os tribunais superiores (STF, STJ, TST, TSE) que julgam recursos contra decisões dos tribunais de segunda instância. Disponível em Glossário Jurídico on line em $<$ http://www.stf.jus.br/portal/glossario/verVerbete.asp?letra=I\&id=161> Acesso em 03 de maio de 2012 .

${ }^{7}$ Juiz de fora - Antigo magistrado brasileiro do tempo do Brasil-Colônia, nomeado pelo poder central; opunha-se ao juiz eleito (SANTOS, 2001:50).
} 
alimentícios à população urbana, a vigilância policial sobre as vias de comunicação. Era a polícia responsável pelo controle do comércio interno do município. Os corregedores eram nomeados pelo rei, com funções primordialmente investigatória e recursal, inspecionando, em visitas às cidades e vilas que integravam sua comarca, como se dava a administração da Justiça, julgando as causas em que os próprios juízes estivessem implicados. O alcaide ou meirinho era o Oficial de Justiça que citava, intimava, penhorava, prendia e cumpria ordens provindas de juízes, corregedores, ouvidores, provedores e demais autoridades judiciárias.

Como nos relata Lopes \& Rios (2009), em dois anos de atuação do ouvidor-geral Pero Borges, transbordam as reclamações de abuso de poder dos ouvidores, que mais que respeitar os Códigos, eram levados pela vontade dos senhores. Diversas denúncias de desvio de dinheiro, excesso ou falta de cumprimento à lei (dependendo de quem fosse o acusado), estrutura precária com falta de materiais básicos para atuação efetiva nas localidades. Pero Borges, por meio de inúmeras reinvidicações ao rei, relatando os "maus tratos"dados à justiça brasileira, solicitava pessoas de formação, capacitadas para atuarem e resolverem os inúmeros problemas por ele detectados nas capitanias. Ainda assim, somente em 1609 que se implanta a primeira Relação no Brasil (um tribunal para julgamento coletivo), na Bahia, sendo composta inicialmente por apenas dez desembargadores. Possuía a seguinte estrutura:

A Relação é concebida para ser composta por dez desembargadores, entre eles o chanceler, que serviria também como juiz da chancelaria, três desembargadores de agravos, um ouvidor-geral, um juiz dos Feitos da Coroa, Fazenda e Fisco, um procurador dos Feitos da Coroa, Fazenda e Fisco, e promotor da Justiça, um provedor dos Defuntos e Resíduos [remanescentes do bens legados], e dois 'desembargadores extravagantes', explica Skidmore. Tal estrutura permanece 
inalterada até 1626, quando se dá a invasão holandesa (SKIDMORE, 1998 apud

LOPES \& RIOS, 2009: 23).

A segunda Relação do Brasil foi implantada em 1751, no Rio de Janeiro, atendendo treze comarcas, dentre elas São Paulo, Ouro Preto, Cuiabá, Goiás, Espírito Santo e Ilha de Santa Catarina. Ela funcionaria até a chegada da corte Portuguesa ao Brasil, momento em que fora transformada em Casa da Suplicação, primeiro Tribunal de última instância do país. A criação da Casa da Suplicação faz parte de um conjunto de inovações na organização judiciária trazido pela vinda da corte real ao Brasil. Naquele momento histórico, o Brasil possuía um sistema judiciário em formação, ainda dependente da Metrópole para decisões em última instância. A criação de um órgão de cúpula no país representou um grande passo para autonomia jurídica do Brasil e o marco inicial de um longo caminho de consolidação da justiça brasileira. A partir daí outras Relações foram instituídas (segundo grau de jurisdição, os atuais Tribunais de Justiça), representativas de outros Estados, como a Relação do Maranhão, Relação de Pernambuco e Relação de São Paulo e, em 1891, estes Tribunais da Relação são substituídos pelos de Apelação e Revista (LOPES \& RIOS, 2009).

Para caracterização completa da organização judiciária da época, trazemos quadro explicativo, proposto também por Lopes \& Rios (2009), do Ordenamento Jurídico no Século XVII (ver Figura 2.1), que se perdurou, com pequenos acréscimos por surgimento de mais alguns órgãos, por quase todo o século XVIII e XIX.

Os documentos analisados neste trabalho foram produzidos por juízes em primeira instância, que na época eram denominados juízes ordinários, sendo estas decisões revistas, em grau de recurso, pelos juízes desembargadores dos Tribunais da Relação ${ }^{8}$, que produziam

\footnotetext{
${ }^{8}$ Representando a Segunda Instância ou Segundo Grau de Jurisdição. Na Justiça atual são chamados de Tribunais de Justiça, entretanto, em Portugal, a denominação Tribunais da Relação ou simplesmente Relação ainda persiste. E o juízes que atuam nesta Segunda Instância, na época eram chamados de juízes da Relação, hierarquicamente classificados como desembargadores.
} 


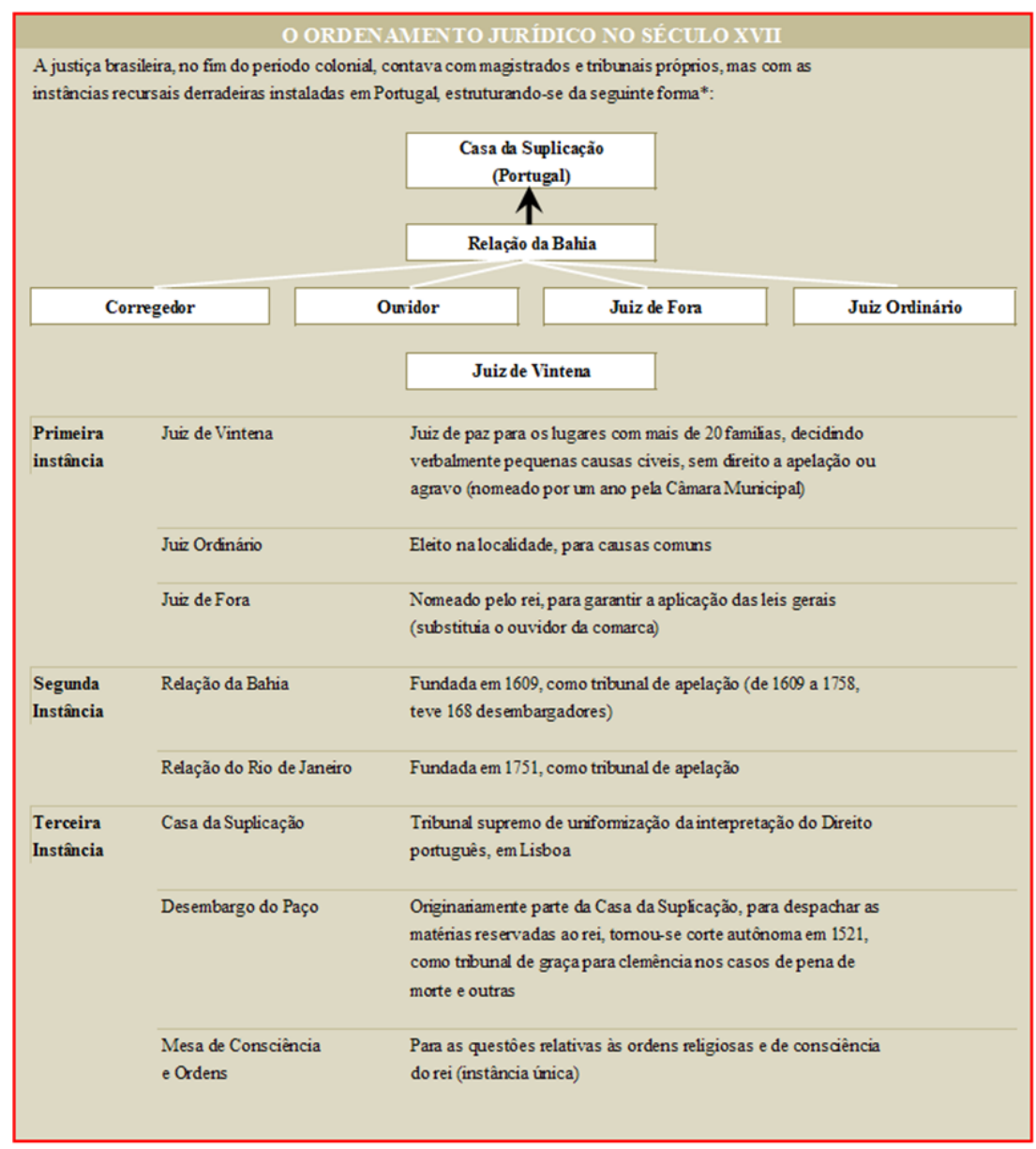

Figura 2.1: O Ordenamento Jurídico no século XVII. Fonte: LOPES \& RIOS, 2009:31

os acórdãos ${ }^{9}$. Os juízes ordinários eram escolhidos pelo povo, dentre aqueles que eram mais bem vistos na região em que moravam, em votação, e cujos mandatos eram anuais. Por isso, muitas vezes, eram pessoas pouco letradas, apenas com bons relacionamentos políticos. Deveriam agir como mandavam as leis, ser diligentes e trabalhar para que naquela cidade, vila ou lugar em que jurisdicionassem não se fizessem malefícios ou malfeitorias, sendo fiscalizados, como já dito, pelos ouvidores (FERREIRA, 1952).

\footnotetext{
${ }^{9}$ Acórdão - S.m. De acordam, ou seja, concordam (3.a p.p. presente do indicativo de acordar); decisão proferida em grau de recurso por tribunal coletivo e superior (CPC, arts. 163 a 165, 556, 563,564 e 619) (SANTOS, 2001:30).
} 
Estava o Direito entregue a homens simples, ignorantes, sob a constante pressão dos poderosos que os rodeavam. Os desembargadores, juízes que compunham as Relações, ainda que fossem homens letrados, mantinham relações de favorecimento para com a elite imperial (eram nomeados pelo Imperador), situação que se repetia nos segmentos inferiores do Judiciário:

A instância máxima da Justiça exerce o papel de hierarquizar as demais instâncias. Mesmo com um controle verticalizado, o que predomina é a vontade dos presidentes das províncias, que detêm mando sobre juízes nomeados e eleitos. A visão que se tem de cidadania na época ainda é a visão do absolutismo, e a prática ainda é a do favorecimento (LOPES \& RIOS, 2009: 39).

\subsection{Aspectos da luta pela liberdade: a escravidão brasileira}

Como país colonizado, vimos que o sistema judiciário foi totalmente importado da metrópole, Portugal. E "a expansão do ordenamento jurídico de Portugal por meio de seu Império de além mar carregou consigo as relações costumeiras de poder, entre as quais inseria-se o escravismo" (CAMPOS, 2004: 17). Ainda Campos (2004), citando Joaquim Nabuco (1999a: 173), trouxe aspectos da escravidão brasileira, nos seguintes termos:

Esse ente [o escravo], assim equiparado, quanto à proteção social, a qualquer outra coisa de domínio particular, é, no dia seguinte à sua alforria, um cidadão como outro qualquer, com todos os direitos políticos, e o mesmo grau de elegibilidade (CAMPOS, 2004:17).

Como todo o sistema judiciário, o legislativo, ou seja, as leis foram igualmente transportadas para a Colônia, sendo necessário, entretanto, no que diz respeito à escravidão, a criação de novas categorias, em virtude da situação que aqui se encontrava: 
A criação de "categorias jurídicas apropriadas para a assimilação de elementos "estranhos", como os africanos e os índigenas. Legitimando as desigualdades e as hierarquias sociais, corpos legislativos variados definiam a função e o lugar desses "estrangeiros" na colônia, incorporando-os, dessa forma, ao Império lusitano. A categoria "parda", para ficarmos num único caso, ligava a pessoa não somente à sua ascendência africana, mas também ao seu passado de cativeiro. Mesmo após a passagem de algumas gerações, reforçava-se assim, na memória dessas pessoas, as restrições civis advindas de sua posição na hierarquia social (CAMPOS, 2004:17-18).

Os documentos aqui analisados são a confirmação, quando fazem parte de processos judiciais que têm como autores negros requerendo a revisão de suas situações como escravos, deste estado de coisas. Mas a escravidão não transcorreu mansa e pacificamente, até a promulgação da Lei Áurea. Ao contrário, os escravos resistiam, lutavam, fugiam, negociavam e até buscavam o sistema judiciário para reverter suas condições. Foi uma resistência e luta permanente, até a conquista da abolição:

A luta dos escravos pela reconquista da liberdade tem início desde os primórdios do cativeiro. Não resistisse cada escravo, individualmente, a sua captura, e não seria necessário pô-lo a ferros, separar os elementos de cada tribo ou etnia de modo a evitar a resistência conjunta através da redução ao estado de incomunicabilidade (dado que falavam diferentes línguas). A redução à imobilidade e a redução ao silêncio, ao lado da ameaça à integridade física com castigos devidamente planejados e hierarquizados, tinham como finalidade evitar, controlar a reação ao aprisionamento e a fuga, individual ou coletiva, do negro prisioneiro. (...) A intenção de apresentar aqui estes antecedentes foi apenas 
deixar claro que o desejo de liberdade dos negros fez parte do seu quotidiano desde o momento do seu aprisionamento (MENEZES, 2009:2).

A partir da segunda metade do século XIX, aumentavam progressivamente as pressões externas e internas para colocar um fim, mesmo que gradativo, à escravidão no país. Segundo Abrahão (1962), o governo estava se voltando ao estudo de condições legais para a efetivação desta abolição, mesmo que lenta e gradual. Como consequência, diversas leis foram editadas, visando a uma maior proteção dos escravos. Em 1831 é aprovada a Lei Evaristo de Morais, que declarou livres todos os negros ingressados no território nacional, mas frequentemente burlada, sendo causa para ingresso de ações de liberdade pelos escravos.

Segundo Lopes (2002), em meio a sucessivas leis de restrição, o tráfico de escravos aumentou consideravelmente em comparação a outros séculos. Se fez necessária então em 1850 a aprovação da Lei Eusébio de Queiroz, para o combate efetivo ao tráfico clandestino, sendo promulgada com o intuito de regulamentar a Lei Evaristo de Morais. A Lei Evaristo de Morais, que já tinha proibido o tráfico, não vinha sendo cumprida, sob a justificativa de que faltaria um decreto para regulamentá-la. As medidas de repressão posteriores ao tráfico instaladas até 1860 são de caráter econômico, criando-se taxas sobre os escravos, sobre sua transmissão e sua consignação.

A Lei 2040, a Lei do Ventre Livre, promulgada em 1871, representou a primeira forma definitivamente legal de se libertar os cativos. Ela declarou a condição de livre aos filhos de mulher escrava que nascessem desde a data da lei, aos que provassem terem entrado no país após 1831 (escravos da Nação), além também de permitir que o próprio escravo comprasse sua liberdade através de um pecúlio. Como continuidade e traduzindo uma evolução da Lei 2040, em 1885 o governo aprova a Lei 3270, conhecida como Lei dos Sexagenários, regulando a extinção gradual do elemento servil. Com somente cinco artigos 
e conhecida também como Lei Saraiva-Cotegipe, ela promoveu uma nova matrícula de escravos, intensificando o controle do governo sobre estas propriedades, como também fixou um teto de indenização para os senhores que alforriassem seus escravos pelo Fundo de Emancipação (fundo criado com os valores recolhidos de impostos sobre a propriedade e negociação de escravos, e estes valores serviriam de pagamento aos senhores que tivessem seus escravos alforriados neste processo instituído pela Lei Rio Branco ou Lei do Ventre Livre). Em 1888, finalmente a aprovação da Lei 3353, Lei da Abolição ou Lei Áurea, que declarou extinta a escravidão no Brasil. Estas leis representaram, na verdade, o reconhecimento público de uma situação a quo. As lutas pela emancipação emergiam de todos os lados e de todas as formas. Fraga Filho (2006) faz um estudo de registros cartoriais em cruzamento com fontes documentais sobre os engenhos, que o possibilitou reconstituir trajetórias individuais e familiares de ex-escravos e seus descentes do Recôncavo Baiano. E, dessas trajetórias individuais, conseguiu traçar um panorama com as marcas das lutas pela emancipação da escravidão. Por exemplo, uma das marcas que ele levanta é a questão dos laços de solidariedade entre escravos de um mesmo engenho e redes familiares e até mesmo a relação com antigos senhores, que eram preservados no tempo da escravidão e ampliados no pós-abolição. Assim, era muito comum, nos próprios engenhos, escravos e libertos cultivarem gêneros de subsistência, que poderiam ser consumidos internamente ou vendido em feiras locais. Como também ele constatou, pela análise de alguns inventários, que os escravos puderam constituir família e manter relações estáveis de uma geração para outra. Levantou em relatos de administradores de engenhos, que pagamentos em dinheiro e alimentos eram feitos a alguns escravos da propriedade que prestavam serviços extras aos domingos. Em outros relatos observou também que alguns escravos eram pequenos lavradores fornecedores de cana aos engenhos. Muitos escravos obtinham recursos com criação de animais, com a pesca, caça, para consumo próprio e para a venda. A criação 
e o cultivo eram feitos em pequenas parcelas de terra cedidas, em dias facultados pelos senhores, geralmente domingo ou dia santo, nos espaços chamados de roça. Estas atividades independentes poderiam abrir possibilidades de alcançar alforria, mas por outro lado, como ressaltou também Fraga Filho (2006), estas atividades independentes eram vantajosas para os senhores pois diminuíam gastos com subsistência e mantinham os cativos ligados à propriedade. Com o passar do tempo, estes espaços de subsistência passaram a gerar conflitos, a medida que estes escravos criaram um senso de 'direitos' sobre as parcelas de terra que cultivavam. Continuando, Fraga diz que frequentar as feiras locais dava aos escravos o acesso aos bens e dinheiros, estabeleciam relações com escravos e libertos de engenhos vizinhos, fortalecendo redes de amizade e comércio com gente da cidade e marinheiros dos portos. Essas relações poderiam ser acionadas no momento em que decidissem fugir do domínio dos senhores, para questionar a legitimidade da escravidão.

Ainda segundo Fraga Filho (2006), a Lei do Ventre Livre foi a lei de maior impacto nas relações escravistas, porque, além de libertar os "ingênuos", instituiu o fundo de emancipação e a matrícula obrigatória dos cativos. Aquele que não fosse matriculado, era considerado livre. Mas, para ele, a grande inovação foi a permissão ao escravo para acionar a Justiça por meio de ações de liberdade em caso de recusa dos senhores em conceder liberdade após apresentação do pecúlio.

Outro aspecto importante que denota o impacto desta lei para Fraga, é a posição dos senhores de engenho frente a mesma: acusavam o governo imperial de pretender violar o direito de propriedade, "devassar a vida íntima das famílias, estabelecer um sistema de delação entre escravos e desorganizar o trabalho"(FRAGA FILHO, 2006: 49). Fraga prossegue dizendo que a Lei do Ventre Livre possibilitou o alcance da alforria no âmbito da legalidade, como também colocou senhores contra senhores, levados pelo interesse de 
manter algum controle sobre a vida dos libertos, ampliou a possibilidade de libertos livres disputarem a liberdade de parentes e amigos escravos. E esta abertura do judiciário ocasionou a tomada de posição de autoridades judiciais, que começavam a emitir decisões a favor da liberdade. Além das autoridades judiciais, as policiais também acabaram se envolvendo a favor dos escravos. Diante da incidência de denúncias de maus-tratos, afinal de contas, agora os escravos sabiam que podiam contar com a interferência das autoridades policiais e judiciais, os escravos fugiam e pediam proteção da polícia, deixando evidente que os senhores já não tinham ou não deveriam ter domínio inconteste sobre suas vidas.

Paralelamente a estas mudanças de posturas de autoridades e conscientização de escravos, o movimento abolicionista crescia. Ainda de acordo com Fraga, os próprios abolicionistas prestavam assistência jurídica, negociavam com os senhores as condições de liberdade, ofereciam proteção aos cativos que aguardavam o desfecho de seus pleitos na justiça, redigiam petições como advogados, promoviam eventos para divulgação do abolicionismo. Além desta proteção por parte dos abolicionistas, aquela rede de amizades e parentesco cultivada pelos escravos favoreciam e ocultavam as fugas. Alguns escravos buscavam refúgio em outras propriedades, perante outros senhores, que, em virtude da escassez de mão-de-obra, acabavam por acobertar a fuga destes escravos. Para concluir, ainda com Fraga Filho (2006: 56), que elenca em resumo as molas propulsoras da libertação dos escravos, ou os temperos da abolição:

O acirramento da disputa, entre senhores de engenho, pela mão-de-obra dos que se libertavam ou que pretendiam libertar-se, as leis emancipacionistas que ampliaram as possibilidades de alforria, a perda da legitimidade da escravidão e a crescente influência do abolicionismo combinaram-se e interagiam de variadas e imprevisíveis maneiras com as iniciativas dos escravos. Foi nesse contexto que os cativos fizeram suas escolhas e criaram projetos próprios de liberdade. 
Marquese (2006: 6), por outro lado, nos traz a ideologia que movimentou as relações escravistas no Brasil. Em um estudo sobre a Dinâmica da escravidão no Brasil, anota, surpreendentemente, a estreita relação entre o volume do tráfico negreiro e o número de alforrias. No fim do século XVIII e início do XIX, a América portuguesa guardava as seguintes proporções: $28 \%$ brancos, $27,8 \%$ negros e mulatos livres, $38,5 \%$ de negros e mulatos escravos e 5,7\% de índios. Essa grande proporção de negros livres se deu pela:

dinâmica do tráfico transatlântico de escravos acoplada à dinâmica da alforria.(...) A associação de negros libertos e livres com o sistema escravista: o grande anseio econômico e social desses grupos era exatamente a aquisição de escravos, ou seja, tornar-se senhor.(...) Diversos trabalhos recentes documentam a prática bastante comum de negros e mulatos livres, libertos e mesmo escravos de serem donos de escravos.

O alto número de escravos importados barateava o custo desta mão-de-obra, sendo o escravo uma mercadoria barata, o que reafirmava a lógica da escravidão brasileira. Favorecia a visão surgida em 1822, nos debates da Corte de Lisboa sobre a Independência, de que escravos libertos eram aliados, criando-se, nesta oportunidade, um artigo constitucional de garantia de direitos a libertos nascidos no Brasil. Ao passo também que esta inclusão constitucional acabou virando, segundo Marquese (2006) peça de propaganda de defesa do tráfico negreiro, no contexto de acirramento das pressões antiescravistas inglesas. Fora uma resposta ideológica decorrente da própria lógica de funcionamento da escravidão já descrita inicialmente, mas desconhecida pela maioria dos dirigentes metropolitanos, que entendiam que o setor de homens negros livres representava mais risco do que segurança à ordem colonial. 
Em contrapartida, aqueles negros que continuavam na situação de escravos não eram considerados cidadãos, e não possuíam os direitos correspondentes. O Código Comercial da época incluía os escravos entre os bens semoventes, acabando por validar o seu comércio, o que na prática era de fato feito, por intermédio de procurações para compra-venda. Com isto, o Estado recolhia impostos sobre as transações, e cobrava normalmente pela emissão de certidões que comprovavam sua posse, bem como de outros documentos como as matrículas que comprovavam a situação de escravo, esta obrigatória. Na realidade, o objetivo deste registro era viabilizar a arrecadação e não averiguar a existência destas pessoas, mesmo porque, nestes documentos de matrícula, constavam apenas o nome de batismo do escravo e de sua mãe, o que dificultava a comprovação da origem deste negro.

Com a crise do setor açucareiro e o progressivo crescimento da produção de café, tal como em outras regiões do País, em 1880, a produção de café na Província de São Paulo correspondia a $40 \%$ da produção nacional. Portanto, neste período pré-libertação, momento em que se intensificavam os movimentos abolicionistas, influenciados principalmente pelo santista José Bonifácio ${ }^{10}$, a mão-de-obra escrava foi supervalorizada, tornando-se objeto raro e cobiçado nos patrimônios dos senhores. Consequentemente, os que ainda eram escravos tinham trabalho redobrado, chegando a jornadas de dezesseis horas por dia, sem folgas, situação a provocar as fugas constantes, inclusive para outras fazendas, denúncias por maus-tratos e exigência excessiva, fatores coloboradores, dentre outros, para o grito final de liberdade.

\footnotetext{
${ }^{10}$ Desde que retornara da Europa o ilustre santista José Bonifácio se chocara e escandalizara com a sociedade de senhores e escravos que encontrara em sua terra: "inumana, injusta, imoral, corrompida e corruptora", que se degradava e degradava o Brasil. Convencido da necessidade urgente de acabar com a chaga social da escravatura, no início de 1820 ele liberta os escravos da Chácara do Outeirinhos, de sua propriedade, onde pretende provar que se pode trabalhar a terra e lucrar sem escravos e senzalas. Nos dois anos seguintes toda a sua energia se voltou para a luta pela Independência, mas quando esta se concretizou, ele voltou para seus ideais abolicionistas (Biblioteca Virtual do Governo do Estado de São Paulo. Disponível em http://www.bv.sp.gov.br. Acesso em 04 de maio de 2012).
} 


\subsection{O pensamento jurídico-filosófico do século XIX}

Oportuno iniciar este capítulo, que intenciona refletir sobre a filosofia, sobre o pensar filosófico, nos apropriando da alusão feita à coruja como símbolo da sabedoria, citada em Bittar \& Almeida (2011). A coruja tudo vê, tudo observa, silenciosamente e nas trevas, em atitude de vigília, se mantendo desperta enquanto tudo ao seu redor descansa. Assim deve ser a busca da sabedoria, por intermédio de um olhar atento para a compreensão do mundo. Um olhar de fora, uma visão excedente ${ }^{11}$ dos fatos, da vida, ou seja, o saber prescinde a experiência (práxis) e a capacidade de absorção reflexiva desta práxis, voltandose para o processo de convívio com o espanto diante do mundo. O alcance da visão da coruja possibilita o distanciamento - "se distancia para enxergar mais e então atacar a sua presa(...) A observação segue a função de apreensão e compreensão."(BITTAR \& ALMEIDA, 2011: 2) Este trabalho, então, fala deste lugar filosófico, já que de outra forma não poderia ser: a teoria orientadora deste estudo foi proposta por um filósofo e o seu Círculo.

Conceituando, continuamos nos apropriando dos dizeres de Bittar \& Almeida (2011: 19), que estabelece a filosofia:

como atividade do pensamento, a especulação distingue-se da mera observação passiva, da mera contemplação admirativa, uma vez que postula, procura as causas primeiras, explica, critica..., favorecendo a liberdade humana de pensar;

a filosofia aparece como uma forma de busca racional para as questões que

\footnotetext{
${ }^{11}$ Bakhtin foi um filósofo da linguagem, portanto, o conceito de excedente de visão do autorcriador, diante da obra, corresponde, diretamente, com a posição da coruja diante da vida, com o agir filosófico diante da praxis: "O autor não só enxerga e conhece tudo o que cada personagem em particular e todas as personagens juntas enxergam e conhecem, como enxerga e conhece mais que elas, e ademais enxerga e conhece algo que por princípio é inacessível a elas, e nesse excedente de visão e conhecimento do autor, sempre determinado e estável em relação a cada personagem, é que se encontram todos os elementos do acabamento do todo, quer das personagens quer do acontecimento conjunto de suas vidas, isto é, do todo da obra."(BAKHTIN, 2010: 11).
} 
a própria ciência se julga impotente para responder. Para além dos estreitos limites da causalidade empírica, pode a filosofia racionalmente avançar, sem recair necessariamente nos domínios da crença e da fé religiosa. Sem compromissos imediatos, sem preocupação com produtos racionais, sem limites tão claramente delineados, sem vínculo de apresentar respostas, com a filosofia a racionalidade humana galga a condição da liberdade intelectual. Seus objetos são amplos, universais e infinitos. Pode, sem dúvida nenhuma, representar grande instrumento de esclarecimento e questionamento sobre meios e fins, sobre os princípios e as causas, sobre os destinos e as metas, sobre o de onde e por onde.

Assim, podemos dizer que a filosofia abarca o estudo dos saberes gerais, o ser e o conhecimento, a reflexão que permite questionamentos, abrindo espaço para outros horizontes, introduzindo novas possibilidades, rediscutindo premissas e princípios, fundando um sentido explicativo para as coisas, reavaliando o que parece sólido e consensual, abrindo abordagens diferenciadas para questões antigas de todas as outras ciências particulares, tendo como objeto principal a busca do ideal de todo ramo do conhecimento.

Como nossos objetos de estudo são discursos proferidos dentro da práxis jurídica, importante se faz o estudo dos princípios fundamentais que orientava estes autores de discursos (juízes e desembargadores) no momento da aplicação das normas ao caso concreto, como igualmente importante entender o caminho desta atividade jurisdicional, constituindo fundamental aspecto o contexto destas enunciações, a ser estudado para buscarmos as teias discursivas, as outras vozes que orientavam, de fato, estes enunciados dialógicos.

O Direito, como uma ciência particular (especializada), também necessita da filosofia do direito, para trazer explicações gerais sobre os ideais da prática jurídica, ou seja, vem para constituir o pensamento jurídico que deve orientar a praxis. A filosofia do direito, 
com a devida autonomia, constitui um conjunto de saberes acumulados sobre o direito que é o seu objeto específico, sem abandonar o fato de que a filosofia do direito é um saber que advém das práticas gerais da filosofia.

Ainda segundo Bittar \& Almeida (2011), a Filosofia do Direito é um saber crítico, é o pensar reflexivo e o agir sobre as construções jurídicas postas pela Ciência do Direito e pela própria práxis do Direito, buscando os seus fundamentos, cientificando-se de sua natureza e criticando as bases e as fissuras sobre as quais se fundam as estruturas do raciocínio jurídico. Desta forma, conhecedores das razões e do objeto do pensar filosófico, nada mais coerente do que agirmos filosoficamente sobre do direito do século XIX, trazendo à tona as nuances dos pensamentos deste período no qual nosssas decisões foram proferidas.

Ressalta Bittar \& Almeida (2011) que a disciplina Filosofia do Direito, autônoma como vista hoje, não tinha o mesmo status no período pré-Moderno, sendo abarcada e reconhecida como Direito Natural, Teoria Racional, Teoria do Direito Natural. Seu surgimento se dá em tempos Modernos, mesmo que ainda com identidade obscura, sendo reconhecida e conquistando maior respeitabilidade ao longo da Modernidade ${ }^{12}$.

Nesta esteira, importante trazermos as correntes jurídico - filosóficas predominantes na Modernidade, a fim de entendermos os paradigmas que nortearam a produção das decisões aqui analisadas. Segundo Lopes (2002), a modernidade se rompe com eventos de grande repercursão, como a reforma protestante e a chegada dos europeus à América, colocando para os juristas novas questões sobre o direito de conquista e descoberta, o direito de posse, invenção, tesouro, liberdade dos mares, e principalmente a alteridade, liberdade natural dos índios. Continua Lopes (2002: 179):

\footnotetext{
${ }^{12}(\ldots)$ O marco desta autonomia, neste processo, será, propriamente, a obra de Hegel, nesta passagem entre o período do jusnaturalismo e do positivismo, especialmente a partir do espectral título Fundamentos da filosofia do direito (Grundliniender Philosophie des Recht) (BITTAR \& ALMEIDA, 2011: 45.
} 
Portanto, a nova teoria do direito, que será elaborada nos séculos XVII e XVIII sob o nome de direito natural deita suas raízes nestes processos e eventos históricos: desenvolvimento capitalista do mercado, fim da cristandade, conquista da América, afirmação do Estado nacional. A nova teoria política e jurídica deve entreter-se com os assuntos da soberania e do pacto de dominação (sujeição) entre soberanos e súditos.

Assevera Lopes (2002) que, diferentemente da tradição clássica, a Modernidade reafirma o sujeito e suas razões individuais. O jusnaturalismo cresce permeado pela racionalidade, estrategismo e razão prática. O paradigma precursor do positivismo jurídico (que contextualiza nossas decisões), foi ancorado nas práticas matematizantes, no dogma do valor segurança, na certeza da funcionalidade do Direito e na ideologia liberal individualista. É a perspectiva de ir do ser ao dever-ser, sendo a justiça assumida como valor máximo, que conduz à verdade ${ }^{13}$. Esta corrente se desenvolve a partir do século XVI, com o objetivo de aproximar a lei da razão, em busca de um Direito mais justo, mais perfeito, protegendo o homem contra quaisquer arbítrio dos governantes. Por ser considerado abstrato e anticientífico, o jusnaturalismo cedeu espaço para o surgimento do positivismo jurídico.

Com a ascensão do positivismo jurídico, o Direito fora equiparado à legislação e completamente afastado da filosofia. Tratava-se de um movimento que reconhecia tão somente a "letra fria da lei". Direito seria o que estaria positivado em texto legal, deixando à margem a ética, moral e princípios.

\footnotetext{
${ }^{13}$ Nesse sentido, Lídia Reis de Almeida Prado (2010: 15-6): "Assim como ocorreu com os outros ramos do conhecimento, a história do pensamento jurídico ocidental está embuida de formalismo, que se evidencia pelo próprio conceito de Direito, entendido como um sistema de normas. Levado às últimas consequências, o formalismo conduziu o Direito ao positivismo legalista da Escola da Exegese e permaneceu no normativismo da Escola de Viena e no pensamento neopositivista. A consequência desse modo de conceber o Direito foi o seu distanciamento da realidade (através da separação exagerada entre o mundo dos conceitos e o mundo dos fatos) de acordo com o princípio que via na sistematização dedutiva o ideal de toda a ciência).
} 
O Código de Napoleão ou $1^{\text {o }}$ Código Francês foi um marco para o positivismo jurídico. Editado em 1804, surge em virtude da corrente-jusnaturalista (razão literal), mas simultaneamente a aniquila, dando início à Escola Positivista, que teve o seu mais alto ponto na Escola Exegética, do silogismo subjuntivo (legalista ou racionalista- dogmática jurídica), pelas quais a aplicação da lei tratava-se de ato mecânico, sendo a lei absoluta e negando qualquer possibilidade de interpretação. Ao juiz somente cabia aplicar a lei ao caso concreto, sem de modo algum interpretá-lo, pois a lei era clara o suficiente (BORGES, 2005).

O Código Napoleônico fora projetado com a pretensão de ser absoluto, sem lacunas, ou seja, qualquer parcela da vida civil teria previsão legal previamente estabelecida, como se fosse pleno e as normas nele contidas como se fossem pedaços de vida objetivada. O pintor francês Jean Baptiste Mauzaisse, com a obra Napoleon Crowned by Time retratou este paradigma ao pintar Napoleão e seu Código (marco do positivismo), no espaço celeste, sobre a espada e sendo coroado pelo deus Tempo (Cronos), como se o projeto de código estivesse fora do tempo e devesse ser interpretado fora da história, em nome da extrema segurança jurídica e absoluta neutralidade que deveria guiar a sua aplicação, excluindo qualquer tipo de interpretação. Da mesma forma, a intenção também era que Napoleão fosse lembrado pelo seu Código e não pelas batalhas.

Com relação à dogmática vigente, agora como foco o ato em si de "aplicação"da norma ao caso concreto, encontramos neste período, como já salientado, a orientação da Escola Exegética, que, em comunhão com o paradigma positivista, tem como base o uso da letra da lei como forma de aplicação do direito. Também chamada de escola legalista e racionalista, afirma que todo o direito está contido na lei e apenas nesta. Qualquer ato ocorrido no meio social estaria previsto em uma lei, logo o direito seria completo e poderia ser aplicado a qualquer caso. Como absoluta, caberia ao juiz, simplesmente, extrair do texto da lei o 
seu significado e aplicá-lo ao caso concreto. Representava o grande apego à norma, sendo colocada diante do fato e cuja consequência lógica seria a decisão. Por consequência, o direito, para os legalistas, seria o conjunto de normas emanadas e positivadas pelo Estado, ou seja, qualquer outra norma de uso social ou costume deveria ser ignorada. O magistrado deveria exercer apenas a função de aplicador da lei, sempre em conformidade com a vontade do legislador, em detrimento dos conceitos pessoais e valorativos. Interpretar significa desigualar ${ }^{14}$.

No Brasil, o paradigma positivista encontrou solo fértil. Foi durante o Segundo Império, isto é, por volta de 1850, que as ideias positivistas chegaram ao Brasil, trazidas por brasileiros que foram completar seus estudos na França. E estas ideias foram aqui muito bem aceitas em virtude da situação de insatisfação geral de políticos e intelectuais face à politica centralizadora e controladora que imperava. Segundo Silva (1982), o Imperador conseguia sempre neutralizar a oposição, pois a luta política realizava-se entre dois partidos, o Conservador e o Liberal, que se revezavam no poder, sendo os membros do Parlamento Imperial representantes da classe ruralista e eleitos por ela, ou seja, representantes da única aristocracia que o Brasil conheceu.

A questão política da época era a escravatura, defendida pelos conservadores, mas combatida pelos positivistas. A cultura intelectual era mais literária do que científica e as classes dirigentes procuravam em geral as profissões jurídicas, constituindo, então, segundo Silva (1982) uma sociedade que não possuía uma filosofia definida que aspirasse por ideias que lhes desse uma nova concepção de valores e orientasse os seus atos. Enfim, a ausência

\footnotetext{
${ }^{14}$ Nesta esteira, assevera Tomaszewski (2005: 3) que "decorrente deste pensamento, surge a concepção mecânica da função jurisdicional, de sorte que a sentença era considerada um ato meramente mecânico; um simples exercício de lógica dedutiva, destituída de qualquer elemento valorativo e alheia à realidade dos fatos.(...) a decisão proferida ou prolatada pelo julgador, seria então assemelhada à construção de um mero silogismo, em que a lei seria a premissa maior; a premissa menor, o caso concreto apresentado à apreciação; e, a conclusão, o decisum".
} 
de cultura e conhecimento teórico, aliada a uma filosofia que apresentasse critérios racionais e seguros, faz florescer o positivismo no Brasil, que constituirá uma válvula de escape e preencherá esta lacuna ideológica. Desta forma, os documentos analisados foram elaborados sob a vigência da visão positivista. A relação entre juiz-sentença era concebida como um exercício lógico, formal, de decodificação da lei, crendo-se na neutralidade ideológica do magistrado. Uma lógica tradicional, sem qualquer tipo de carácter valorativo, o raciocínio jurídico reduzido a uma simples aplicação dedutiva da lei ao fato. Entretanto, como restará demonstrado em nossas análises, "é impossível a perfeita regulação normativa para a complexa vida social, razão pela qual inexiste uma regra jurídica adequada para cada circunstância concreta."(PRADO, 2010: 17). A sociedade está em constante transformaçãoe o Direito não tem como acompanhar este ritmo. Por conseguinte, assistimos mais tarde, a uma alteração deste cenário, sobretudo com o chamado Grupo de Bruxelas, que reagiu contra a pretensão reducionista do raciocínio jurídico. "(...)Luís Recaséns Siches, Theodor Viehweg, Michel Villey, Chaim Perelman, além de outros, preconizavam um alargamento do campo da lógica jurídica para abranger outros processos de conhecimento que correspondem à vida real do Direito."(PRADO, 2010: 16)15. Nesse sentido, há um novo olhar: o juiz como ativo participante desta prestação jurisdional, trazendo sua intuição, seus valores, sua formação, ou seja, sua personalidade ${ }^{16}$ a balizar a sua decisão, perfazendo a lógica do humano, lógica do razoável: o razoável é o justo, aquilo que se coaduna com a realidade concreta, com a práxis.

\footnotetext{
${ }^{15}$ Ainda Prado (2010: 16), citando Chaim Perelman, complementa que a teoria do Direito prevalente no século XX conduz ao reconhecimemento do papel do juiz na elaboração do Direito e à prevalência da eficácia da lei sobre a sua validade.

${ }^{16}$ Nesse diapasão, Prado (2010: 21) traz os pensamentos de Jerome Frank, pertencente à escola do Realismo Americano, que surgiu na primeira metade do século XX: 'O aspecto importante na sentença, embora não o único - continua o autor - é a personalidade do juiz, sobre a qual influem educação geral, a educação jurídica, os valores, os vínculos familiares e pessoais, a posição econômica e social, a experiência política e jurídica, a filiação e opinião política, os traços intelectuais e temperamentais (...)'
} 
Dentre os pensadores do grupo de Bruxelas, que entendiam a função jurisdicional como criadora, temos Luis Recaséns Siches, que defendeu a Lógica do Razoável, como uma razão impregnada com pontos de vista estimativos, critérios de valorização, de pautas axiológicas, trazendo ensinamentos de sua própria experiência e a do próximo, através da história. (TOMASZEWSKI, 2005: 4) Neste novo paradigma, as decisões devem ser razoáveis, vinculadas à dimensão humana. O juiz com uma função criadora, se valendo de um complexo de valorações particulares sobre o caso concreto, na busca do justo, do razoável. Segundo Luis Recaséns Siches, apud Prado (2010: 18):

A lógica tradicional não serve ao jurista para compreender e interpretar de modo justo os conteúdos das disposições jurídicas; não lhe serve para criar a norma individualizada da sentença judicial ou decisão administrativa[...] Realmente o juiz decide por intuição e não por uma inferência ou silogismo dos que se estudam na lógica; decide por uma certeza que se forma de modo direto e não em virtude de umm raciocínio[...]

Continua Prado (2010) dizendo que o papel do sentimento do juiz fica evidenciado até mesmo na etimologia da palavra sentença, que vem de sentire, ou seja, expressar uma emoção, uma intuição emocional, buscando o juiz as intuições direcionadas na concretização da solução justa do litígio. Este entendimento da função jurisdicional como atividade criadora, se coaduna perfeitamente com a teoria balizadora deste estudo: a teoria dialógica do discurso ${ }^{17}$; o juiz, ao produzir seu discurso, estará totalmente atrelado à realidade que

${ }^{17}$ A expressão foi cunhada pela primeira vez por BRAIT (2010), como estará detalhado no capítulo da fundamentação teórico - metodológica. 
o envolve, realidade esta entendida como o ser, o homem, com princípios e valores constituídos, com uma carga axiológica permeada por "outros", pelo social, que direcionará sua intuição e a sua busca do justo, do razoável ${ }^{18}$.

\subsection{O processo judicial e seus atores}

O Estado, para exercer as funções que lhe cabe, dentre elas a jurisdicional, cria órgãos que se responsabilizam pelas demandas, direitos e deveres, estabelecidos, principalmente, na Constituição Federal. À frente da função jurisdicional, há órgãos especializados, encarregados da jurisdição, e que não podem atuar senão pautados em leis e princípios e, segundo Theodoro Junior (2009), pautados também por um sistema de atuação ou método, que vem a ser o processo, dada a própria natureza da atividade que lhes competem. Entre o pedido da parte e a tutela jurisdicional se impõe a prática de atos prescritos por lei, que constituem o procedimento judicial - a forma de agir em juízo - que se materializam no processo.

Ao vetar a seus súditos fazer justiça pelas próprias mãos e ao assumir a jurisdição, o Estado não só se encarregou da tutela jurídica dos direitos subjetivos privados, como se obrigou a prestá-la sempre que regularmente invocada, establecendo, de tal arte, em favor do interessado, a faculdade de requerer sua intervenção sempre que julgue lesado em seus direitos. (HUGO ALSINA, apud THEODORO JUNIOR, 2009: 55).

\footnotetext{
${ }^{18}$ Prado (2010), citando Karl Llewellyn: "(...) a mente do juiz primeiro antecipa a decisão que considera justa (dentro da ordem jurídico-positiva) e depois procura a norma que pode servir de fundamento a essa solução, atribuindo aos fatos a qualificação apropriada. Percebe-se, (...), a admissão da existência, no processo decisório - sem excluir o prisma legal e o valorativo -, de aspectos extralógicos, relacionados com conteúdos subjetivos do juiz."(PRADO, 2010: 17).
} 
Assim, quando provocado, o Estado agirá por intermédio deste procedimento, que se materializará no processo judicial. Entretanto, segundo Theodoro Junior (2009), tão importante quanto este procedimento, é o estabelecimento de uma relação jurídica de direito público, geradora de direitos e obrigações entre o juiz e as partes, com objetivo de obter a atuação da vontade concreta da lei (tutela jurisdicional), vinculando todos os sujeitos desta relação processual e o juiz, formando uma relação trilateral, todos à procura de uma solução para o conflito estabelecido em torno da pretensão de direito material de um litigante e da resistência do outro. Os atores desta relação, deste processo, são os sujeitos processuais, incluindo o juiz, o autor e o réu, ou seja, todos aqueles que figuram nessa relação jurídica processual. O juiz como sujeito imparcial, e as partes (autor e réu) como partes propriamente ditas. O autor do processo é aquele que invoca a prestação jurisdicional e toma a posição ativa de instaurar a relação processual. Aquele que fica na posição passiva e sujeita à relação instaurada chama-se réu ou demandado. "As pessoas físicas, maiores e capazes, que têm capacidade de exercício no direito civil, terão, em regra, capacidade processual integra, e assim, podem, por si, estar em juízo."(ALVIM, 2005: 27, grifos do autor).

Segundo Alvim (2005), no que tange à pessoa do juiz, num sentido lato da expressão, ele deve ser considerado funcionário público, com peculiaridades respeitantes à sua posição e funções, que o acabam diferenciado em muito de um funcionário público comum. Situamse, na relação processual, acima das partes e desinteressadamente, de forma imparcial, como legítimo representande da função jurisdicional e do Estado. O juiz, tal como o órgão que representa - Poder Judiciário - exerce suas funções de forma independente, ou seja, tem autonomia política e jurídica. Não tem qualquer subordinação hierárquica no desempenho de suas funções, se submetendo somente à lei e à sua própria consciência. Segundo Freitas (2008), ele é a vox legis, o intérprete da lei, intérprete "neutro"(veremos 
com as análises que a neutralidade não existe) e imparcial. Além disso, sua autonomia política se manifesta nas garantias constitucionais de vitaliciedade (não pode perder o cargo a não ser por sentença), inamovibilidade (não pode ser removido de um lugar para o outro, a não ser com seu assentimento ou promoção) e irredutibilidade de vencimento.

\subsection{As decisões: definindo o gênero jurídico e sua estrutura}

Quando nos remontamos ao século XIX, verificamos que o processo civil, que deveria conduzir o processo judicial de causas civis, lhe ditando normas e requisitos formais, assim não o fazia. Em uma análise mais apurada dos institutos legais processuais daquele século, verificamos a ausência de requisitos formais prescritos pela lei brasileira para a existência e validade destes gêneros. Durante todo o período colonial, as Ordenações Filipinas, promulgadas em 1603, eram vigentes no Brasil, no que tange ao processo civil. Mesmo após a Independência política, o país ainda herdou de Portugal normas processuais contidas nas Ordenações (Livro III- disciplinava o processo civil) - situação que foi assegurada pelo decreto de 20 de outubro de 1823, que prescrevia que as Ordenações teriam vigência em tudo que não contrariasse a soberania e o regime brasileiro ${ }^{19}$ :

Título LXVI - Das sentenças diffinitivas (4) - Todo Julgador, quando o feito fôr concluso sobre a diffinitiva, vera e examinará com boa diligencia todo o processo, assim o libello, como a contestação, artigos, depoimentos, a elles feitos, inquirições, e as razões allegadas de huma e outra parte: e assi dê a sentença difinitiva, segundo o que achar allegado de huma parte e da outra, ainda que lhe a consciencia dicle outra cousa (1), e elle saiba a verdade ser em contrario

\footnotetext{
${ }^{19}$ BRASIL. Ordenações Filipinas. Disponível em http://www1.ci.uc.pt/ihti/proj/filipinas/13p667.htm.
} Acesso em 13 de Novembro de 2011. 
que no feito fôr provado; porque sómente ao Priucipe, que não reconhece Superior (2), he outorgado per Direito, que julge segundo sua consciencía (3), não curando de allegações, ou provas em contrario, feitas pelas partes, por quanto he sobre a Lei, e o Direito não presume, que se haja de corromper por affeição $(\ldots)$

Quando promulgado o Código de Processo Penal de 1832, algumas normas foram instituídas para o processo civil. Ele continha um capítulo com uma disposição provisória acerca da administração da justiça civil (com apenas 27 artigos). Entretanto, somente o artigo 16 trata do contéudo da sentença, sem se ater muito à forma ${ }^{20}$ :

Art. 16. As sentenças que se extrahirem do processo não conterão mais do que o pedido, e contestação ou articulado das partes, e a sentença com os documentos a que elle se refere. Ocorre que estas disposições foram posteriormente canceladas. Em 1840, a Lei 261, alterou substancialmente o Código de Processo Penal, retirando a validade das disposições provisórias civis, representando um verdadeiro retrocesso político e legislativo.

Em 1850, foi editado o primeiro Código Comercial (Regulamento 737) que determinava a ordem do juízo no processo comercial- $1^{\circ}$ Código Processual editado no Brasil. Foi o primeiro instituto que trouxe regulamentações processuais, mas se restringia às causas comerciais. Até o momento, as causas cíveis ainda continuavam a ser regidas pelas Ordenações e suas alterações, por isso, após sofrerem inúmeras alterações, em 1876 elaborou-se uma Consolidação das Leis Processuais (Resolução Imperial de 28 dezembro de 1876). Em seu artigo 479, encontramos disposição sobre as decisões judiciais:

${ }^{20}$ BRASIL. Código de Processo Penal de $1832 . \quad$ Disponível em dhttp://www.planalto.gov.br/ccivil_03/Leis/LIM/LIM-29-11-1832.htm. Acesso em 13.11.2011. 
DA SENTENÇA - Artigo 479. Achando o Juiz que a causa está em termos de ser decidida, examinará atentamente todo o processo, e dará a sua sentença definitiva, segundo o que achar alegado e provado de uma e da outra parte, ainda que a consciência lhe dite outra. (RIBAS, 1915:265)

Após o advento do Código Comercial (1850), em 1890, editou-se o regulamento 763, que estendia a aplicação das normas do Regulamento 737 para as causas civis, mandamento este constante já em seu artigo $1^{\underline{O}}$ :

Art. $1^{\mathrm{O}}$ São applicaveis ao processo, julgamento e execução das causas civeis em geral as disposições do regulamento n. 737 de 25 de novembro de 1850, excepto as que se conteem no titulo $1^{\mathrm{o}}$, no capitulo $1^{\mathrm{O}}$ do titulo $2^{\mathrm{O}}$, nos capitulos $4^{\mathrm{O}} \mathrm{e}$ $5^{\mathrm{O}}$ do titulo $4^{\mathrm{O}}$, nos capitulos $2^{\mathrm{O}}, 3^{\mathrm{O}}$ e $4^{\mathrm{O}}$ e secções $1^{\mathrm{a}}$ e $2^{\mathrm{a}}$ do capitulo $5^{\mathrm{O}}$ do titulo $7^{\mathrm{O}}$, e no titulo $8^{\mathrm{O}}$ da primeira parte..$^{21}$

Destarte, ao retomarmos o Decreto 737 (Código Comercial), encontramos, em seu artigo 232, algumas condições para elaboração das decisões ${ }^{22}$ :

Art. 232. A sentença deve ser clara, summariando o Juiz o pedido e a contestação com os fundamentos respectivos, motivando com precisão o seu julgado, e declarando sob sua responsabilidade a Lei, uso ou estilo em que se funda.

Salienta-se que até o momento o Brasil ainda não possuía um Código de Processo Civil. Somente em 1939 foi aprovado um Código de Processo Civil, que já em 1973, foi alterado, sendo o nosso Código de Processo Civil de hoje, com alterações (que somam 31

\footnotetext{
${ }^{21}$ BRASIL. Decreto $\mathrm{n}^{\mathrm{o}} \quad 763$ de 19 de setembro de 1890 . Disponível em http://www.jusbrasil.com.br/legislacao/116752/decreto-763-90. Acesso em 01.06.2012)

${ }^{22}$ BRASIL. Decreto $\mathrm{n}^{\mathrm{o}} 737$ de 25 de novembro de 1850 . Disponível em http://www6.senado.gov.br/legislacao/ListaPublicacoes.action?id=80659. Acesso em 13 de novembro de 2011.
} 
leis, alterando partes do Código). Já neste instituto processual encontramos disposições que prescrevem os requisitos de validade quanto à forma e conteúdo do gênero sentença e acórdão, e que, surpreendentemente, de forma tácita, já norteavam a produção das decisões do século XIX. Por isso, torna-se oportuno analisarmos o funcionamento do sistema jurídico atual, no que concerne às decisões. Podemos constatar que as suas prescrições coincidem, em todos os aspectos, com a estrutura das decisões e o trâmite do processo judicial dos processos do século XIX, deixando a impressão de que a lei somente veio referendar uma práxis jurídica consolidada.

Até mesmo nos aspectos ritualísticos principais, a justiça seguia da mesma forma que nos dias atuais, ou seja, o processo deveria seguir procedimentos, possuir carimbos, selos, falas padrões e a linguagem forense que perduram até hoje. Podemos dizer que a diferença principal está na técnica de registrar a escrita - a pena, até o princípio do século XX, quando passou a ser datilografado e nos dias atuais por computador.

Quando analisamos o sistema jurídico atual, verificamos a existência de duas modalidades de sentença: 1) as que decidem o mérito, podendo ser procedente/improcedente; 2) sem julgamento de mérito - juiz finaliza esta etapa do processo sem apreciação do objeto da causa. Estas sentenças são impugnáveis pelo recurso de apelação para os Tribunais, que, após decidirem, proferirão peças chamadas acórdãos. Quando não recorrida ou quando esgotados todos os recursos e instâncias, atinge a sentença a situação de transitada em julgado, a partir deste momento será efetivamente definitiva. Da mesma forma ocorre com o acórdão. Depois de proferido pelo Tribunal, as partes ainda poderão recorrer para o Supremo Tribunal, quando estas decisões versarem sobre o rol de questões explícitas na lei. No caso do não cabimento de recurso ou de as partes não terem recorrido, assume então esta decisão também a condição de definitiva. 
Nas leis processais vigentes, no artigo 458, encontramos os requisitos ou formas consideradas válidas para a construção do gênero sentença. Ele diz que são partes fundamentais deste gênero:

1. O relatório, que conterá os nomes das partes, a suma do pedido e da resposta do réu, bem como o registro das principais ocorrências havidas no andamento do processo;

2. Os fundamentos, em que o juiz analisará as questões de fato e de direito;

3. O dispositivo, em que o juiz resolverá as questões, que as partes lhe submeterem.

Como o próprio nome já infere, é pelo RELATÓRIO que o magistrado narra resumidamente os fatos e a sequência dos atos, desde o início do processo até a decisão, identificando as reinvindicações de cada parte, suas argumentações e o "ponto controvertido". Aqui, em tese, ${ }^{23}$ não há qualquer emissão de juízo de valor por parte do juiz. Também pelo relatório o juiz avalia o aspecto formal do processo, se o procedimento foi adequado ao ordenamento jurídico.

Na parte subsequente, a FUNDAMENTAÇÃO, ocorrerá a exposição dos fundamentos do magistrado, que poderão ser de fatos e direitos. É a fundamentação da razão da decisão. Aqui poderemos detectar, como veremos nas análises, a escolha de recursos linguísticos denotando a ideologia que perpassa este discurso. Isto porque será neste momento a escolha pelo magistrado dos componentes jurídicos, sociais, políticos e econômicos que relacionará com a norma abstrata que rege a discussão, posicionando-se em relação ao mérito.

\footnotetext{
${ }^{23}$ É esperado, para esta parte do gênero, que não haja qualquer posicionamento do juiz, devendo tão somente expor os principais eventos ocorridos no processo. Mas entendemos que, do ponto de vista linguístico-discursivo, isto é impossível, porque a linguagem não é neutra. Nos apropriando dos pensamentos de Hanna Arendt, o homem nasce duas vezes: o nascimento biológico e o discursivo. É o que veremos com as análises das decisões. Esta citação de Arendt, da obra "A condição Humana"(1999), foi feita pela professora Dra. Rosineide de Melo, em banca de qualificação, na versão impressa deste trabalho.
} 
E, por fim, a DECISÃO. Trata-se do capítulo final, momento em que o juiz concluirá seu raciocínio, revelando sua identidade e sua posição como autoridade estatal. Dará sentido às suas palavras ao falar de sua posição como Estado-juiz, mas suas palavras terão relação, sem dúvida, mesmo que inconscientemente, com determinada hierarquia de valores, que impõem, de modo decisório, o seu juízo de valor sobre aquela relação jurídica.

A sentença será proferida por um órgão monocrático, ou seja, somente um juiz será o responsável pela decisão, diferentemente do acórdão, que advém de um órgão colegiado do Tribunal, sendo proferido, em conjunto, por três juízes desembargadores. Com estrutura muito semelhante a das sentenças, os acórdãos também seguem o prescrito em lei, no aspecto formal, para sua constituição. O acórdão será lavrado em harmonia com a orientação que tenha prevalecido nesta junta de três desembargadores, devendo o vencido, quanto à decisão ou quanto aos simples fundamentos, assinar em último lugar, com a sucinta menção das razões de discordância. Tal como a sentença, o acórdão principia pelo RELATÓRIO, em que se enunciam sucintamente as questões a decidir no recurso, expondo em seguida os fundamentos que guiarão a decisão, sendo concluindo, então, pela decisão. Trata-se, portanto, o acórdão, de uma representação, resumida, da conclusão a que se chegou, não abrangendo toda a extensão e discussão em que se pautou o julgado, mas tão-somente os principais pontos da discussão ${ }^{24}$. Se o relator ficar vencido relativamente à decisão ou a todos os seus fundamentos, o acórdão é lavrado pelo primeiro adjunto vencedor, o qual assegura ainda os termos que se seguirem, para integração, aclaração ou reforma do acórdão. Se o relator ficar apenas vencido quanto a algum dos fundamentos ou relativamente a qualquer questão acessória, o acórdão é lavrado pelo juiz que o presidente designar. Quando o Tribunal de Segunda Instância confirmar inteiramente, não existindo o

\footnotetext{
${ }^{24} \mathrm{O}$ artigo 631 do Código de Processo Civil nos traz os elementos de formação do acórdão, devendose observar também, na parte aplicável, o preceituado nos artigos 562 a 568 (aspectos formais relativos às sentenças, relacionados anteriormente).
} 
voto vencido para o julgado em primeira instância (sentença), quer quanto à decisão, quer quanto aos respectivos fundamentos, pode o acórdão limitar-se a negar provimento ao recurso, remetendo para os fundamentos invocados na decisão impugnada. Quando a decisão de fato não tenha sido impugnada nem haja lugar a qualquer alteração da matéria de fato, o acórdão limita-se a remeter para os termos da decisão da primeira instância proferida sobre aquela matéria, como ocorreu em muitos de nossos julgamentos analisados ${ }^{25}$.

Como as demais decisões judiciais, o acórdão deve apresentar o nome de seu relator, dos membros componentes do órgão julgador (câmara, turma, seção, órgão especial, plenário, etc.) e o resultado da votação. Como já explicitado, caso a votação não seja unânime, o voto vencido, ou seja, o entendimento divergente, mesmo que de um membro apenas do órgão julgador, deverá ser exposto no acórdão, como já explicitado. Este registro é especialmente importante pois as decisões não-unânimes comportam outros recursos da parte vencida.

Assim que distribuído no Tribunal, o processo será encaminhado ao desembargador sorteado, designado para o papel de relator do recurso (o juiz relator é o responsável pelo andamento deste processo no Tribunal, da confecção do relatório até a decisão), sendo definidos também os juízes adjuntos, que decidirão em conjunto com o juiz relator. Cada um desses juízes terá um prazo para examinar o processo, sendo que o juiz relator deve preparar um projeto de acórdão. Este projeto de acórdão será conhecido pelos juízes adjuntos uma sessão antes da data marcada para julgamento. Neste dia, o juiz relator faz sucinta apresentação do projeto de acórdão, e os juízes adjuntos dão o seu voto, sendo a

\footnotetext{
${ }^{25}$ Prescreve o artigo 165 do Código de Processo Civil brasileiro atual que os acórdãos devem ser proferidos em observância ao disposto no art. 458 (mesmo artigo que orienta formalmente a sentença), ou seja, devem conter, obrigatoriamente, o relatório, a fundamentação e a parte dispositiva - na qual se encontra a decisão propriamente dita -, e ainda uma ementa, que conforme o art. 563 do Código Processo Civil, significa o resumo que se faz dos princípios expostos em uma sentença ou em um acórdão, ou o resumo do que se contém uma norma, levado à assinatura da autoridade a quem compete referendá-la ou decretá-la.
} 
decisão tomada por maioria e a discussão dirigida pelo Presidente do Tribunal. O acórdão definitivo é lavrado em harmonia com a orientação que tiver prevalecido, devendo o juiz vencido, quanto à decisão ou quanto aos fundamentos, assinar em último lugar, com a breve menção das razões de discordância.

O juiz como enunciador, e as partes, como coenunciadores, nessa interação, cada um assume sua identidade a partir e no interior desse sistema de lugares sociais. E, neste processo de subsunção da norma ao caso concreto, o magistrado desenvolve interpretações de todos os outros discursos que envolvem este processo judicial (todos os outros atos); assim é uma prática de linguagem que incorpora outras práticas - são discursos jurídicos que sustentam o discurso sentencial. E, na teia destas interpretações, a pessoa do juiz, ser humano como nós, da mesma forma sofrem influências de várias ordens, psicológicas, morais, espirituais e intelectuais, o que, em nossa concepção influencia diretamente na construção dos discursos produzidos, o que demonstraremos com as análises dos documentos.

Segundo Bittar (2001), o discurso decisório torna realidade ativa e individualizada aquilo que se encontra apenas em hipótese de dever-ser na norma. Discurso normativo baseia-se em situações hipotéticas, de forma generalizante e objetiva; a aplicação desse discurso a um caso concreto, real, será conferida pelo discurso decisório-que terá o poder de individualização do sentido abstrato dos textos normativos.

Diante disto, podemos dizer que as decisões judiciais são discursos de síntese, formulado a partir da proposta textual legislativa e de um universo de particularidades (fatos, outros discursos) que se encontram dentro do procedimento e que suportam este discurso síntese. Nestes momentos decisórios, os juízes, na qualidade de representantes do Estado, com base nos fatos, na lei e no direito, entrega a prestação jurisdicional requerida pelas partes.

Na construção do discurso decisório, o juiz, ao fazer mão do recurso de citação, o faz de maneira denunciadamente tendenciosa (CUNHA, 2005: 112): "[...] essa operação é a 
de um enxerto entre dois tecidos. A inserção de uma citação supõe o trabalho do sujeito que cita, que o fragmento de discurso selecionado não é neutro para o receptor."

Toda a descrição da constituição e das partes do gêneros sentenças e acórdãos, bem como a sua consideração como gêneros do discurso, estão embasadas na teoria de gêneros proposta por Bakhtin e o Círculo de pensadores. Isto porque Bakhtin (1992-2010) afirma que o conceito de gênero discursivo refere-se a formas típicas de enunciados que se realizam em condições e com finalidades específicas nas distintas situações de interação social. Sentenças e acórdãos são modalidades do gênero jurídico (dentre outros-petição inicial, contestação, recurso, etc.) e uma espécie de ato processual. Constitui ato exclusivo do juiz, com a finalidade de colocar fim a um conflito entre duas partes (de forma relativa, tendo em vista a possibilidade recursal).

Tendo por base a concepção bakhtiniana de que gêneros são textos materializados que apresentam características sociocomunicativas definidas pelos conteúdos e propriedades funcionais, pelo estilo e composição propriamente dito, podemos deduzir então que as decisões, como gênero jurídico, também possuem características próprias, definidas pela praxis jurídica ou pela lei. ${ }^{26}$

Importante se faz, portanto, o conhecimento em detalhes da estrutura dos nossos documentos (sentenças e acórdãos), para que a análise se dê de forma integral e possibilite, assim, detectarmos o caminho de construção destes discursos dialógicos.

${ }^{26}$ A concepção teórica acerca do gênero do discurso será trabalhada em detalhes no capítulo 3. 


\section{Capítulo 3}

\section{Fundamentação teórico-metodológica}

\subsection{Introdução}

Como suporte fundamental deste trabalho, traremos, neste capítulo, as teorias que norteiam a pesquisa, por intermédio de um levantamento bibliográfico acerca dos principais temas incidentes no estudo do corpus, a começar, na seção 3.2, com noções acerca da ciência que baliza a leitura e decodificação das decisões manuscritas, enquanto que na seção 3.3, destacamos, principalmente, alguns conceitos propostos por Bakhtin e o Círculo dentre outros necessários para a compreensão do percurso realizado pelos produtores das decisões judiciais, objeto dessa dissertação.

\subsection{A ciência filológica}

Castro (1992) apud Megale \& Cambraia (1999: 1) define filologia como "a ciência que estuda a gênese e a escrita dos textos, a sua difusão e a transformação dos textos no decurso de sua transmissão, as características materiais e o modo de conservação dos suportes textuais, o modo de editar os textos com respeito ao máximo pela intenção manifesta do autor". A filologia se debruçará sobre o texto manuscrito e impresso e, por meio dele, se dedicará então ao estudo da língua em todos os seus aspectos, linguístico, literário, crítico-textual, sócio-histórico, no tempo e no espaço. Estes textos serão literários ou não, 
perfazendo assim o sentido mais amplo do termo. Em um sentido mais restrito, se concentrará nos textos literários, antigos e modernos, manuscritos e impressos, segundo Almeida (2009), "para estabelecê-lo, fixá-lo ou restituí-lo à sua genuinidade e prepará-lo para ser publicado.". Neste sentido serão estudados os aspectos do texto como um objeto físico, como uma materialidade, levantando as técnicas e materiais utilizados para sua produção, condições históricas que cercaram e influenciaram sua produção, sua conservação, número de cópias, bem como o estudo do processo de edição destes textos. Todas estas ações constituem as funções substantiva e adjetiva da filologia.

A filologia tem ainda uma terceira função, a transcendente, que nos toca diretamente. Trata-se de uma função mais ampla, com objetivos mais abrangentes de reconstituição da mentalidade da época através do estudo dos aspectos gráficos, gramaticais, lexicais e discursivos do texto. Os documentos manuscritos a serem estudados, neste trabalho, ao serem transcritos e editados, a fim de viabilizar a análise, valer-se-ão, então, da ciência filológica, em sua função transcendente, para sua leitura e transcrição, deixando assim de ser um fim em si mesmo para serem "instrumento que permite ao filólogo reconstituir a vida espiritual de um povo ou de uma comunidade em determinada época" (ALMEIDA, 2009: 225).

Poderíamos destacar que a "filologia é uma ciência aplicada, dado que seu escopo, a sua finalidade específica é fixar, interpretar e comentar os textos. De modo que o conhecimento científico da língua funciona como meio, como instrumento para que a ciência atinja seu fim próprio". (MELO, G. 1981: 7) Assim, para o exercício de todas as suas funções, além da história e da literatura, outras ciências afins auxiliarão o trabalho filológico: a codicologia, que estuda os manuscritos ou códices em seu aspecto material, a paleografia, que tem como fim o estudo da escrita antiga (MELO, G. 1981: 7):

(...) De posse de um manuscrito, o filólogo tem de saber de que época é a 
letra, deve interpretar e desfazer as abreviaturas, deve conhecer o estado da língua nos primeiros séculos, para, lendo o manuscrito, saber se se trata de um original, de uma cópia contemporânea ou de cópia posterior, se o copista foi fiel ou se inseriu modernismos no texto; deve conhecer a história, os usos e costumes, a cultura da época do manuscrito, para interpretar o texto, entender as alusões, as imagens etc., etc.

A depender da finalidade, intenção do editor e número de testemunhos existentes (cópias, edições, reproduções do documento), variará as formas de reprodução destes textos. Segundo Almeida (2009: 225), "basicamente são cinco os tipos de edição ou reprodução, diferenciando-se pelo grau de interferência do editor: I. Fac-similar; II. Diplomática; III. Semidiplomática; IV. Modernizada; V. Crítica". Estes tipos de edições, baseados na forma de estabelecimento do texto, fazem parte do grande grupo de edições monotestemunhais, transcrições baseadas em apenas um testemunho do texto, o original.

A fac-similar, também chamada de mecânica, fac-similada ou fac-símile, é a digitalização, fotografia, xerografia, do texto original, por isso permite estudos de diversas naturezas. A edição diplomática é a transcrição tipográfica em que se conservam todas as características estruturais, gráficas, linguísticas, com indicação, inclusive, de interferências de terceiros, sinais públicos e deteriorações, sendo a leitura e decodificação o nível de interferência do editor, possibilitando assim estudo histórico e linguístico em todos os níveis. Nesta, porém, diferentemente da mecânica, há um baixo grau de mediação do editor, que fará transcrição rigorosa do documento, com todos os seus elementos. Com um maior grau de mediação por parte do editor, está a semidiplomática, conhecida também como paleográfica, paradiplomática ou diplomático-interpretativa. Neste tipo haverá uma maior intervenção do editor: 
pois, no processo de reprodução do modelo, realizam-se modificações para o tornar mais apreensível por um público que não seria capaz de decodificar certas característica originais, tais como os sinais abreviativos.(...) o editor atua de forma mais interventiva, através de operações como do desenvolvimento de sinais abreviativos, inserção ou supressão de elementos por conjectura, dentre outras (embora qualquer uma dessas operações fique explicitamente assinalada na reprodução): os principais objetivos de todas essas operações são (1) o de facilitar ainda mais a leitura do texto e torná-lo acessível a um público menos especializado e, portanto, mais amplo que o da diplomática; e (2) o de tentar retificar falhas óbvias no processo de cópia do texto, tais como supressão ou repetição de letras etc. (CAMBRAIA, 2005: 95).

Na edição crítica, haverá uma completa uniformização, com um grau máximo de mediação do editor. Há alguns autores que sugerem outras denominações para este nível de edição, como, por exemplo, as chamadas modernizada e interpretativa. Ficamos neste momento com a classificação posta por Almeida (2009), que considera a existência de cinco tipo de edições, sendo a última denominada de crítica. E, para este estudo, como dissemos, nos utilizaremos da edição semidiplomática, com disposição justalinear da reprodução fac-similar.

Se faz necessário também, para a realização de qualquer uma das edições citadas acima, uma série de procedimentos que guiarão o editor neste processo. São as chamadas normas ou critérios de edição. Segundo Cambraia (2005), como cada edição atenderá a uma finalidade, alguns princípios devem nortear o editor quando da criação destas normas: serem elas apropriadas ao tipo de edição; elas devem possibilitar a satisfação de finalidade da edição; devem apresentar coerência interna; devem ser explícitas e devem ser aplicadas rigorosamente. 
Conhecer um pouco sobre a ciência filológica e suas nuances são esclarecimentos fundamentais para a consecução do fim almejado neste trabalho: a edição semidiplomática de sentenças judiciais proferidas no século XIX, como meio para análise dialógica destes discursos proferidos dentro da esfera jurídica. No capítulo 4 serão apresentadas a reprodução fac-similar e a leitura semidiplomática de cada fólio (cada folha de um manuscrito denominação dada pela filologia). Todos os documentos, compostos por fólios e suas particularidades, como número de páginas, nome das partes, nome e resumo da causa, virão seguidos da cópia fac-similada e sua respectiva edição justaposta. Os documentos serão numerados conforme ordem cronológica dos números dos processos do qual fazem parte. Assim, numeraremos em ordem crescente, acrescentando, a estes números as abreviaturas, S - para as sentenças e A - para os acórdãos, ficando, por exemplo, a sentença do primeiro processo $(234 / 1867)$, como D1 (documento 1) S (sentença)= D1S. As edições foram feitas conformes normas e justificativas norteadoras, que virão expressas antes das respectivas reprodução e transcrição destes documentos. 


\subsection{Análise/Teoria Dialógica do Discurso}

De antemão, imprescindível esclarecer o título desta seção. Podemos dizer que trataremos aqui de "teoria"dialógica do discurso, denominação esta proposta por Brait (2010), já anunciando que os conceitos propostos por Bakhtin e o Círculo são a nossa referência, ou seja, a análise do discurso "russa". Como salientado por Brait (2010), ainda que não tenham tido por objetivo a formação de uma teoria, com um conjunto de preceitos sistematicamente organizados, funcionando como uma perspectiva teórica fechada, com categorias prontas a priori, aplicáveis de forma mecânica, é perfeitamente lícito arriscar que o conjunto das obras do Círculo motivaram o nascimento de uma teoria/análise dialógica do discurso, representando a "indissolúvel relação existente entre língua, linguagens, história e sujeitos que instaura os estudos da linguagem como lugares de produção de conhecimento de forma comprometida (...)"(BRAIT 2010:10).

Partimos do pressuposto de que o homem é um ser social em constante relação, e, para que a convivência aconteça, é imprescindível a linguagem, que o compromete e interliga. Ou melhor dizendo, esta linguagem só existe quando estamos diante de sujeitos "sociais", sendo a mesma fruto desta constante relação, desta língua em uso.

A linguagem, necessária para este relacionamento social, não é algo divino, tampouco um presente da natureza, é um produto desta atividade humana coletiva, deste viver em sociedade, em todos os seus aspectos, desde sua origem, organização econômica e sociopolítica. Segundo Voloshinov (1993), não se admite pensar o homem em sociedade e primordialmente os direitos e obrigações que regem esta organização, sem a linguagem:

(...) Aparecen las fórmulas jurídicas, todavia estrechamente ligadas a las fórmulas religiosas. En um cierto sentido, la palabra sacraliza, con su antigua 
autoridad mágica, las leyes ventajosas para uma minoría dirigente, que favorecen la servidumbre de la mayoría sometida. El complejo sistema jurídico que encontramos ya entre los pueblos más antiguos, como los sumerios y los egipcios, sería obviamente impensable sin el lenguaje. No sólo las leyes jurídicas escritas, sino también las leyes morales no escritas, se crean, se explican, y se convierten em uma fuerza coercitiva sólo com la aparición del lenguaje humanoํ. (VOLOSHINOV apud SILVESTRI \& BLANCK, 1993: 230).

Entretanto, o estudo da língua aqui não se fará por si só, isolado, como procedimento submetido a teorias e metolologias. Partimos, como Bakhtin, de outro lugar, de uma nova disciplina, a metalinguística. Na obra Problemas da poética de Dostoiévski, Bakhtin afirma, logo no início do capítulo $O$ discurso em Dostoiévski, que intitula o capítulo como discurso porque:

temos em vista o discurso ou seja, a língua em sua integridade concreta e viva e não a língua como objeto específico da linguística, obtido por meio de uma abstração absolutamente legítima e necessária de alguns aspectos da vida concreta do discurso. Mas são justamente esses aspectos, abstraídos pela linguística, os que têm importância primordial para os nossos fins. Por este motivo as nossas análises subsequentes não são linguísticas no sentido rigoroso do termo. Podem ser situadas na metalinguística, subentendendo-a como um estudo - ainda não-constituído em disciplinas particulares definidas - de modo absolutamente

\footnotetext{
1"Aparecem as fórmulas jurídicas, entretanto estreitamente ligadas às fórmulas religiosas. Em um sentido, a palavra santifica, com sua antiga autoridade mágica, as leis favoráveis ao líder da minoria, favorecendo a servidão da maioria. O complexo sistema jurídico que encontramos entre os povos mais antigos, como os sumérios e os egípcios, obviamente seria impensável sem a linguagem. Não só as leis jurídicas escritas, mas também as leis não escritas morais, são criadas, são explicadas, e tornam-se força coercitiva apenas com o surgimento da linguagem humana."(tradução nossa)
} 
legítimo - os limites da linguística. As pesquisas metalinguísticas, evidentemente, não podem ignorar a linguística e devem aplicar os seus resultados (....). Devem completar-se mutuamente e não fundir-se (...) (Bakhtin, 2002: 181).

Por isso, as análises aqui irão além dos limites da frase. Empresto o objeto da metalinguística, as relações dialógicas, que são extralinguísticas: a língua como fenômeno integral e suas relações, que se situam no campo do discurso. Esta comunicação dialógica que constitui o verdadeiro campo da vida da linguagem ${ }^{2}$.

Na esteira da teoria dialógica do discurso, trata-se de um princípio básico do pensamento bakhtiniano a consideração de que o discurso do eu não é puro ao trazer a voz do outro em sua constituição, o eu se constitue pela presença do outro em mim:

O objeto do discurso do falante, seja esse objeto qual for, não se torna, pela primeira vez objeto do discurso em um dado enunciado, e um dado falante não é o primeiro a falar sobre ele. (...) O falante não é um Adão, e por isso o próprio objeto do seu discurso se torna inevitavelmente um palco de encontro com opiniões de interlocutores imediatos (...) ou com pontos de vista, visões do mundo, correntes, teorias, etc. (BAKHTIN, 2010: 300).

Todo discurso é, para o autor, constitutivamente dialógico, definindo-se pelo diálogo entre os interlocutores e pelo diálogo com outros textos. Bakhtin (1975/1998: 139-40) tem clareza a respeito das vozes que perpassam os discursos, da mais simples esfera da comunicação verbal às mais complexas:

\footnotetext{
${ }^{2}$ Nesse sentido, Beth Brait (2010: 12-3) afirma que: "(...) Esse traço fundante diz respeito ao fato de que a abordagem do discurso não pode se dar somente a partir de um ponto de vista interno ou, ao contrário, de uma perspectiva exclusivamente externa. Excluir um dos pólos é destruir o ponto de vista dialógico, proposto e explicitado pela teoria e pela análise, e dado como constitutivo da linguagem. É a bivocalidade de "diálogo"situado no objeto e na maneira de enfrentá-lo, que caracteriza a novidade da Metalinguística e de suas consequências para os estudos da linguagem".
} 
Qualquer conversa é repleta de transmissões e interpretações das palavras dos outros. A todo instante se encontra nas conversas "uma citação"ou "uma referência"àquilo que disse uma determinada pessoa, ao que "se diz"ou àquilo que "todos dizem", às palavras de um interlocutor, às nossas próprias palavras anteriormente ditas, a um jornal, a um decreto, a um documento, a um livro, etc.

Sudatti (2007: 119) acrescenta:

Toda palavra, do seu nascimento à sua morte, é inevitavelmente no mínimo dupla. Desta forma, o dizer do sujeito traz consigo sempre a voz do outro. A morte ou o não ser é o estado de não ser ouvido, de não ser reconhecido ou lembrado, pois ser significa comunicar, ser para um outro e pelo outro para si mesmo.

E esta apropriação da palavra, do discurso do outro, não é somente feita de forma literal como nas citações, mas muitas vezes por força do contexto, do material extralinguístico:

por maior que seja a precisão com que é transmitido, o discurso de outrem incluído no contexto sempre está submetido a notáveis transformações de significado. O contexto que avoluma a palavra de outrem origina um fundo dialógico cuja influência pode ser muito grande. (...) A palavra alheia introduzida no contexto do discurso estabelece com o discurso que a enquadra, mas uma amálgama química (no plano do sentido e da expressão): o grau de influência mútua do diálogo pode ser imenso. (...) Por isso, ao se estudar as diversas formas de transmissão do discurso do outrem, não se pode separar os procedimentos de elaboração deste discurso dos procedimentos de seu enquadramento contextual 
(dialógico): um se relaciona indissoluvelmente ao outro. Assim como a formação, também o enquadramento do discurso de outrem (o contexto pode de maneira muito remota começar a preparação para a introdução deste discurso) exprimem um ato único da relação dialógica com este discurso, o qual determine todo o caráter da transmissão e todas as transformações de acento e de sentido que ocorrem nele no decorrer desta transmissão (BAKHTIN, 1975/1998: 141).

Para Bakhtin, existem vários tipos de dialogismo, ou dialogismo em diversos níveis, ou seja, existem várias formas de transmissão do discurso do outro e sobre isso Brait (1994: 24-5) comenta:

Chama a atenção, ainda, o fato de que há dialogismo de diferentes graus e que devem ser considerados em sua especificidade (...). Nesse ponto, a dimensão das vozes, que segundo Bakhtin só podem ser registradas por um enfoque translingüístico, assume o caráter de visões do mundo ou percepções realizadas através do discurso: as vozes são sociais, são pontos de vista que estabelecem relações entre línguas, dialetos territoriais e sociais, discursos profissionais e científicos, linguagem familiar etc.

Todos os textos serão dialógicos, porque o dialogismo é constitutivo da linguagem. E este dialogismo, ou estas vozes, textos, que se farão ver ou entrever nestes discursos assim se farão por intermédio de recursos linguísticos. Por isto, quando da análise das decisões, nos fixaremos em uma das formas de expressão deste dialogismo constitutivo: o discurso citado ou discurso relatado - a presença do "discurso do outro"em discursos. "O discurso citado é o discurso no discurso, a enunciação na enunciação, mas, é ao mesmo tempo, um discurso sobre o discurso, uma enunciação sobre a enunciação". (BAKHTIN/VOLOSHINOV, 1929/2010: 150). 
Segundo Melo (2001), as marcas do dialogismo citado ${ }^{3}$ aparecem de três formas, como diretamente abordado na obra Marxismo e Filosofia da Linguagem, sob a ótica literária - o Discurso Direto, Indireto e o Indireto Livre. Não colacionamos a explicação sobre o Indireto Livre porque nosso corpus não traz este tipo de recurso:

1. Discurso Direto (DD): é um tipo de discurso que pode ser preparado (utilização de itálico, inserção de comentários entre parênteses, utilização de ponto de exclamação, interrogação etc.) e esvaziado (apreciação e valor emocional transmitem-se às palavras do herói; o peso semântico diminui, mas se reforça a significação). No DD, os temas são antecipados pelo contexto e coloridos pelas entoações do autor, as quais são quase sempre acompanhadas por um enfraquecimento da objetividade do contexto narrativo; as fronteiras da enunciação são enfraquecidas. Quanto à forma, há um condicionamento ao verbo introdutor, assim, o autor joga sobre o herói a responsabilidade daquilo que é dito. Com o entrecruzamento de contextos e discursos, há simultânea participação de dois discursos diferentemente orientados em sua expressão.

2. Discurso Indireto (DI): é um discurso que requer uma elaboração e uma completude em sua construção. Pode ser analisador do conteúdo (o que disse o falante) e analisador da expressão (que caracteriza não só o objeto do discurso, mas o próprio falante). Assim como no DD, o autor joga sobre o herói a responsabilidade daquilo que é dito, mas agora sob outra forma: introduzindo o discurso citado pela conjunção 'que' seguida de verbo (disse, pensou etc.).

\footnotetext{
${ }^{3}$ No caso da citação, Bakhtin analisa não a estrutura gramatical de formas como o discurso direto, indireto e indireto livre, mas particularmente a dinamica que se estabelece entre contexto narrativo e discurso citado. (MARINHO, 2008: 235)
} 
O fio condutor do nosso estudo é a teoria dialógica do discurso, como explicitado anteriormente. Entretanto, considerando a recorrência de aparecimento em nosso corpus, importante trazermos também, neste momento, a enriquecer nossa análise, uma quarta classificação do discurso relatado, feita por Authier Revuz. Ela, retomando Bakhtin e o dialogismo, amplia esta classificação, trazendo outra forma de empregar o discurso do outro, por intermédio da "modalização do discurso em discurso segundo (cf. 2.1. - segundo fulano; para retomar as palavras de fulano)". (AUTHIER - REVUZ, 1998:135). Para conceituar esta nova classificação (que se apresenta em dois tipos) de Authier Revuz (1998), pedimos licença para continuar nos emprestando da objetiva sintetização feita por Melo (2001):

1. Modalização em Discurso Segundo (MDS): é um discurso que trata de uma afirmação sobre um mesmo acontecimento. Essa afirmação é modalizada por remeter a um outro discurso, caracterizando-se como "segunda", dependente desse primeiro discurso. As formas "segundo fulano"integram um grupo de elementos modalizadores diversos (parece-me, é certo, talvez, obviamente etc.) com a finalidade de modalizar pela referência a um outro discurso. A modalização pode ser sobre o conteúdo da afirmação: segundo x, de acordo com x, é x quem o diz ou sobre o emprego de uma palavra (modalização autonímica em discurso segundo).

2. Modalização Autonímica em Discurso Segundo (MA): é o tipo de discurso em que a modalização se dá sobre o emprego de uma palavra, tida como emprestada de um exterior: como diria x, para falar de modo, para retomar uma expressão, segundo as palavras de $\mathrm{x}$ etc. (MELO, 2001: 15).

O objetivo das classificações é metodológico, ou seja, a busca do real sentido do dizer 
prescinde a análise linguística destes enunciados; as marcas das vozes dos outros encontramse no discurso, e é este discurso que nos dará as "categorias"orientadoras das análises. E esta busca das outras vozes, dos outros discursos não deve ser dissociada daquele discurso que lhe cedeu lugar, ou seja, discurso narrativo. "O objeto verdadeiro da pesquisa deve ser justamente a interação dinâmica dessas duas dimensões, o discurso a transmitir e aquele que serve a transmiti-lo"(BAKHTIN, 2010: 154) .

Ao percorrermos todas as obras de Bakhtin e o Círculo, percebemos que os conceitos são trabalhados de forma integrada, e em uma aparente evolução. Assim, tratá-los separadamente, traçando suas construções e definições, não é tarefa fácil. Porque, por exemplo, as vozes que se articulam nos discursos, se entrelaçam aos elementos e características do gênero. No que tange diretamente ao nosso corpus, vemos que as decisões judiciais têm como traço característico marcar as vozes de forma direta, com citações de jurisprudências e doutrinas, por meio do discurso indireto, sendo o juiz o enunciador das vozes de autor e réu, ou ainda por intermédio de um discurso em modalização segunda, no qual as vozes de autor, réu, testemunhas, leis, se entrelaçam e dão corpo a voz do juiz, como autor e grande comandante do seu discurso; ou seja, o estilo do gênero aqui se mistura aos conceitos de formas de apresentação do discurso de outrem ${ }^{5}$.

Cabe prosseguir com a apresentação dos conceitos de enunciado e enunciação. Na obra

\footnotetext{
${ }^{4}$ Nesse sentido, Bakhtin (2010: 161) continua explicitando a existência e a dinâmica que se estabelece entre o discurso narrativo e o citado: "Estabelecemos as tendências fundamentais da dinâmica da orientação recíproca do discurso citado e do discurso narrativo. Essa dinâmica encontra sua expressão linguística concreta nos esquemas de transmissão do discurso de outrem e nas variantes dos esquemas de base, que constituem, de alguma forma, os indicadores da relação de força que se estabelece entre o contexto narrativo e o discurso citado num determinado momento do desenvolvimento da língua."(BAKHTIN, 2010: 161).

5 "Quando estamos diante de textos verbais, o trabalho metodológico analítico e interpretativo, de longa tradição na nossa área, se dá, sempre, esmiuçando campos semânticos, micro e macro organizações sintáticas, marcas e articulações enunciativas que caracterizam o(s) discurso (s) em foco e indicam sua heterogeneidade, o gênero a que pertencem e os gêneros que nele se articulam, a tradição das atividades em que se inserem, o inusitado de sua forma de ser discursivamente, sua participação nas esferas de produção, circulação e recepção."(BRAIT, 2008: 96)
} 
bakhtiniana não encontraremos estas concepções prontas e acabadas, com sentidos diferenciados. Por vezes são empregadas como sinônimas e suas particularidades construídas ao passar das obras. Não nos cabe aqui ampliar a discussão, mas deixemos claro que no conjunto da obra estes conceitos encontram-se implicados. Por exemplo, em Estética da Criação Verbal (1992/2010) estas noções de enunciado/enunciado concreto e enunciação são trazidas no desenvolvimento do conceito de gêneros do discurso, afirmando-se que o emprego da língua efetua-se em forma de enunciados, como uma unidade de comunicação discursiva, podendo ser orais, escritos, concretos e únicos, proferidos pelos integrantes dos diferentes campos da atividade humana, porque todos os campos estão relacionados ao uso da linguagem. Temos então enunciação como o ato em si de produzir estes enunciados já descritos. E estes enunciados refletem as condições específicas e finalidades de cada campo $^{6}$.

A vida é quem faz com que a língua em uso entre em ação. Ninguém fala no vazio, é indispensável a existência de interlocutores, a interação verbal entre estes interlocutores, ou seja, entre indivíduos socialmente organizados, que trocam enunciados. Para entender estes enunciados, se faz necessária a recuperação do espaço, tempo, conteúdo destas enunciações, a fim de se chegar ao verdadeiro sentido daquilo dito.

Assim, as relações do homem em sociedade que determinarão a linguagem. Podemos dizer então que o homem sempre falará de um lugar social. A escrita organiza o pensamento social, organiza o trabalho, tendo assim, uma função social. A enunciação, desta forma, não é individual, mas singular. Segundo Freitas (2008), toda palavra dirigida a um interlocutor terá duas faces: procede de alguém e se dirige a alguém, constituindo um produto de

${ }^{6}(\ldots)$ "O enunciado, nessa perspectiva, é concebido como unidade de comunicação, necessariamente contextualizado. Uma mesma frase realiza-se em um número infinito de enunciados, uma vez que são únicos, dentro de situações e contextos específicos, o que significa que "frase"ganhará sentido diferente nessas diferentes realizações 'enunciativas' "(BRAIT \& MELO 2008: 63). 
interação, não se restringindo apenas ao diálogo em si, visto que a enunciação carrega sempre a fala do outro; é por causa da presença deste que o outro toma a palavra. Conclui, assim, Freitas (2008) que o princípio dialógico da linguagem se constitui na língua como um fenômeno social, como interação verbal, sendo o homem um ser de linguagem, que se realiza ao relacionar-se a outro, por meio dos gêneros do discurso.

Todos os diversos campos da atividade humana estão ligados ao uso da linguagem. Compreende-se perfeitamente que o caráter e as formas desse uso sejam tão multiformes quanto os campos da atividade humana, o que, é claro, não contradiz a unidade nacional de uma língua. O emprego da língua efetua-se em forma de enunciados (orais e escritos) concretos e únicos, proferidos pelos integrantes desse ou daquele campo da atividade humana. (...) Evidentemente, cada enunciado particular é individual, mas cada campo de utilização da língua elabora seus tipos relativamente estáveis de enunciados, os quais denominamos gêneros do discurso (BAKHTIN, 1992/2010: 261).

Ao analisarmos cada enunciado, devemos retomar o processo de interação e suas especificidades. Os interlocutores, ao enunciarem, o fazem de um lugar, estão inseridos em um contexto, que dará sentido a esta interação. Portanto, estes enunciadores agem a partir de determinadas esferas de atividades, seja do ambiente doméstico, religioso, político, da escola ou do tralbalho. De algum lugar eles falam, e este lugar estará implicado no dizer, orientando a forma deste falar.

Conforme os conceitos de esfera e campo desenvolvidos pelo Círculo Bakhtiniano, podemos afirmar que a esfera jurídica, como um campo da atividade humana, propagará tipos de textos compatíveis com a área do conhecimento e com a prática profissional e jurídica. As sentenças serão avaliadas como um gênero do discurso jurídico, devendo, o autor-juiz, 
para sua confeç̧ão, compreensão e validade, atender aos requisitos estabelecidos para estas formas de enunciados.

Cada campo terá 'regras' que determinarão a forma desses enunciados naquele determinado campo, sendo essas regras determinantes deste gênero. Cada esfera determinará as condições de existência do gênero, como o seu conteúdo, seu estilo e sua construção composicional, ou seja, o campo determinará questões individuais de seleção e opção vocabular, estrutura frasais e preferências gramaticais, em correspondência ao estilo do gênero. Cada campo elaborará, assim, seus tipos relativamente estáveis de enunciados, os seus gêneros do discurso. Conforme Bakhtin (1992/2010: 262):

A riqueza e a diversidade dos gêneros do discurso são infinitas porque inesgotáveis as possibilidades da multiforme atividade humana e porque em cada campo é integral o repertório de gêneros, que cresce e se diferencia à medida que se complexifica um determinado campo.

Ater-nos-emos tratar da noção de estilo, porque toca diretamente as análises das decisões. Todo estilo está obrigatoriamente ligado aos gêneros do discurso, que o determina, implicando, segundo Brait (2008) coerções linguísticas, enunciativas e discursivas próprias da atividade em que se insere. Mas, estes enunciados podem refletir também a individualidade de quem fala ou escreve, em maior ou menor grau, a medida do tipo de gênero que se trate. Bakhtin reconhece que os gêneros mais favoráveis ao estilo individual são os da literatura de ficção, ao passo que as condições menos propícias para o reflexo da individualidade da linguagem estão presentes naqueles que requerem uma forma padronizada, por exemplo, os pertencentes à esfera jurídica. Estabeleçemos, neste momento, o estilo como visão de mundo, e a escolha por eles como a refletir a visão de mundo do autor naquela determinada obra; o locutor determinando as escolhas dos recursos lexicais, fraseológicos 
e gramaticais da língua, interligando, de forma dialógica, os gêneros, os enunciados e os destinatários, perfazendo assim o estilo do gênero, que se consolida com a tradição ${ }^{7}$.

Partindo deste posicionamento, poderemos dizer, a priori, que as nossas decisões, mesmo tratando-se daqueles gêneros menos propícios aos estilos individuais, ainda assim revelarão as individualidades destes juízes, autores de suas decisões, que construirão seus discursos baseados na escolha propositada dos recursos linguísticos que melhor lhes atendem.

Surge então a noção da autoria, visto que os conceitos de estilo, autor, ouvinte não estão dissociados, como todos os outros conceitos dentro da obra de Bakhtin e o Círculo. O estilo, que tem natureza social, está dialogicamente relacionado com o autor do discurso e o ouvinte, que determinarão a forma e o conteúdo da obra ${ }^{8}$ :

A voz do herói sobre si mesmo e o mundo é tão plena como a palavra comum do autor; não está subordinada à imagem objetificada do herói como uma de suas características, mas tampouco serve de intérprete da voz do autor. Ela possui independência excepcional na estrutura da obra, é como se soasse ao lado da palavra do autor coadunando-se de modo especial com ela e com as vozes plenivalentes de outros heróis (BAKHTIN, 1981: 3).

Além disso, Bakhtin (1997: 184) afirma também que "todo enunciado tem uma espécie de autor, que no próprio enunciado escutamos como seu criador". Como já explicitado, mesmo sendo o gênero jurídico pouco propício a estilo individuais, por requererem forma

7"O estilo é o homem", dizem; mas poderíamos dizer: o estilo é pelo menos duas pessoas ou, mais precisamente, uma pessoa mais o seu grupo social, na forma de seu representante autorizado, o ouvinte - o participante constante na fala interior e exterior de uma pessoa. (BAKHTIN/VOLOCHINOV, 1926: 16)

${ }^{8}$ Chamamos estilo a unidade de procedimentos de enformação e acabamento da personagem e do seu mundo e dos procedimentos, por estes determinados, de elaboração e adaptação (superação imanente) do material. (BAKHTIN, 2010: 186) 
rígida padronizada, ainda assim, quando da análise, poderemos constatar que, mesmo que superficialmente, aspectos da individualidade da pessoa do juiz influenciarão nas escolhas dos discursos retomados e na forma como serão retomados. E admitimos aqui o juiz enunciador como autor-criador, que possui um excedente de visão, que se completa no outro, que tem a sua palavra "inexoravelmente contaminada do olhar de fora, do outro que lhe dá sentido e acabamento" (TEZZA, 2008: 210)․ . O autor-criador é o centro controlador, que com o excedente de visão, se posiciona axiologicamente e comanda os diversos dizeres sociais, as vozes, que percebe e valora, a seu modo e conveniência. O magistrado, como um autor-criador, quando transmite, pelas decisões, o modo como o Estado se posiciona diante daquele conflito, não anula suas conviç̧ões pessoais, ou seja, ao construir o seu discurso, este autor é fatalmente orientado por vozes sociais e também por suas vozes internas, pelo seu eu interior:

Ainda que o magistrado não faça uma opção consciente por uma determinada hierarquia de valores, ao exercer o poder, estará optando e impondo de modo decisório o seu juízo de valor sobre determinada relação jurídica. O modo como fará uso de seus poderes na condução do processo e na interpretação das leis, dependerá de sua opção por uma ou várias correntes de interpretação, oriundas das múltiplas escolas hermenêuticas conhecidas. Portanto, a neutralidade axiológica nada mais é do que um mito a ser definitivamente extirpado do plano jurídico e especificamente do espaço de atuação do poder jurisdicional,

\footnotetext{
${ }^{9}$ Para Bakhtin, o autor-criador é a consciênca de uma consciência, uma consciência que engloba e acaba a consciência do herói e do seu mundo; o autor-criador sabe mais do que seu herói. Temos ai um excedente de saber e um primeiro pressupusto da visão de mundo bakhtiniana, um princípio básico: a exotopia, que podemos simplificar definindo-a como o fato de que só um outro pode nos dar acabamento assim como só nós podemos dar acabamento a um outro. Cada um de nós, daqui onde está, tem sempre apenas um horizonte; estamos na fronteira do mundo em que vivemos - e só o outro pode nos dar um ambiente, completar o que desgraçadamente falta ao nosso próprio olhar.
} 
porquanto ao sentenciar, seja acolhendo ou rejeitando o pedido, o juiz estará

valorando fatos à luz de princípios e normas do ordenamento jurídico vigente.

(GOMES, 1995: 24)

Por último, convém trazer algumas palavras concernentes à estratégia discursiva que traz a "voz da autoridade", nos momentos em que o juiz cita uma lei ou uma decisão para balizar sua fundamentação, fato recorrente em nossas decisões. Bakhtin, a esse respeito ${ }^{10}$, nos traz o que ele denomina de duas dimensões constitutivas do discurso ou duas categorias de palavras: uma dimensão de autoridade e outra de persuasão, que, apesar de diferentes, atuam concomitantemente no momento da enunciação. O discurso de autoridade demanda que o reconheçamos, sem questionamentos, enquanto que o discurso internamente persuasivo, afirma-se pela apropriação do discurso do outro, de forma que possa transformá-lo e povoá-lo com nossas próprias palavras.

A palavra autoritária religiosa, política, jurídica, moral, a palavra do pai, dos adultos, dos professores, dos juízes, entre outros não necessita de persuasão interior para a consciência, pois já a encontramos unida à autoridade; ela deve ser reconhecida e aceita, sua força argumentativa está na sua tradição, no seu reconhecimento público, na notoriedade. Já a palavra persuasiva não tem este status de autoridade, de notoriedade, por isso, ela é, comumente, metade nossa, metade de outrem.

De acordo com Bakhtin (2010: 294):

Em cada época, em cada círculo social, em cada micromundo familiar, de amigos e conhecidos, de colegas, em que o homem cresce e vive sempre existem

10 "O objetivo da assimilação da palavra de outrem adquire um sentido ainda mais profundo e mais importante no processo de formação ideológica do homem, no sentido exato do termo. Aqui, a palavra de outrem se apresenta não mais na qualidade de informações, indicações, regras, modelos, etc., - ela procura definir as próprias bases de nossa atitude ideológica em relação ao mundo e de nosso comportamento, ela surge aqui como a palavra autoritária [de autoridade] e como a palavra interiormente persuasiva"(Bakhtin, 1975/1998:142). 
enunciados investidos de autoridade que dão o tom, como as obras de arte, ciência, jornalismo político, nas quais as pessoas se baseiam, as quais elas citam, imitam, seguem. Em cada época e em todos os campos da vida e da atividade, existem determinadas tradições, expressas e conservadas em vestes verbalizadas: em obras, enunciados, sentenças, etc. Sempre existem essas ou aquelas idéias determinantes dos "senhores do pensamento" de uma época verbalmente expressas, algumas tarefas fundamentais, lemas, etc.

Assim, considerando as decisões como discurso, dialogicamente constituído e organizado harmoniosamente por um autor-criador, que rigorosamente conduz e organiza as vozes que perpassam o seu discurso, poderemos e devemos recuperar estes outros - social, discurso interno, valores, vozes dos personagens (autor e réu do processo), a fim de encontramos o sentido de um discurso que, dentro de um tempo e espaço específico, configuram e representam a luta do ser livre dentro de um país escravocrata. 


\section{Capítulo 4}

\section{Apresentando a materialidade: reprodução fac-similar e leitura semidiplomática}

\subsection{Normas de transcrição}

Neste capítulo, serão apresentadas a reprodução fac-similar e a leitura semidiplomática de cada fólio (cada folha de um manuscrito - denominação dada pela filologia). Todos os documentos, compostos por fólios e suas particularidades, como número de páginas, nome das partes, nome e resumo da causa, virão seguidos da cópia fac-similada e sua respectiva edição justaposta. Os documentos serão numerados conforme ordem cronológica dos números dos processos do qual fazem parte. Assim, continuaremos com os números já estabelecidos, acrescentando, neste momento a estes números as abreviaturas, S - para as sentenças e A - para os acórdãos, ficando, por exemplo, a sentença do primeiro processo (234/1867), como D1 (documento 1) S (sentença) = D1S.

As edições obedeceram a normas e justificativas norteadoras, que virão abaixo, seguidas, então, das respectivas reprodução e transcrição destes documentos.

1. Cotejar a edição semidiplomática com a reprodução fac-similar. 
2. Preservar as características linguísticas e grafemáticas do original, mantendo eventuais erros de ortografia e grafias divergentes.

3. Desenvolver as abreviaturas.

4. Palavras ilegíveis serão marcadas por parênteses, acrescentadas da palavra 'ilegível', como em (ilegível).

5. A leitura por conjectura (quando há um problema na grafia da palavra que torna parte ou todo ilegível, embora se possa recuperar a palavra, por conjectura), sem possibilidade de falha, será assinalada com o uso de colchetes simples, como em ci[vil]'. No caso de leitura duvidosa, empregar-se-á parênteses no trecho em que possa haver outras interpretações ou nos quais, embora legíveis, haja dúvidas em relação à interpretação, como em test(emunha) — que também pode ser test(amento).

6. Numerar as linhas — de 5 em 5 - ao lado do texto editado. Não serão contadas como linhas do documento, as anotações feitas por terceiros, nem serão contadas as linhas impressas (papel timbrado).

7. Incluir cabeçalho na primeira página de cada sequência de manuscrito editado, que será composto por uma sinopse com dados relevantes do documento: tipo do documento, remetente e destinatário, data e resumo. Depois da sinopse, na próxima linha, será apresentada a indicação do fólio, numerado conforme a numeração original constante dos autos do processo.

8. O número de fólios será indicado mencionando-se também se trata-se do fólio recto ou verso, conforme numerado dentro do processo.

9. Os números que se referirem às datas, páginas de documentos, leis, decretos, Jurisprudências, etc. (por exemplo: $1^{\mathrm{O}}$ de Junho de 1860, folhas 5, Lei 10 ), sejam 
eles cardinais ou ordinais, serão transcritos como se apresentarem nos manuscritos originais. Com exceção quando se tratar de abreviações para nomes de meses (por exemplo, 9bro > Novembro).

10. As transcrições que não couberem em uma única folha terão o tamanho de sua fonte reduzida.

11. As transcrições que excedam o limite da linha terão o tamanho de sua fonte reduzida.

12. No cabeçalho, os nomes relevantes no documento serão transcritos conforme aparecem no manuscrito, respeitando sua grafia.

13. As assinaturas simples e/ou as rubricas do punho de quem assina serão sublinhadas e negritadas.

14. Os preâmbulos não serão editados. Muitos fólios trazem as descrições de atos processuais anteriores às sentenças ou acordãos, que dizem respeito somente ao trâmite processual e não diretamente ao conteúdo dos documentos aqui analisados. Por isso, não serão editados.

15. Alguns documentos trazem anotações ao lado direito, na transversal do documento. Quando se tratarem de anotações de terceiros, não serão editadas, fazendo-se referência em nota no início do fólio. Quando forem anotações do próprio punho do documento editado, serão transcritas ao final do documento, em negrito. 


\subsection{DOC 1}

Documento: Sentença

Remetente: juiz ordinário representando a Justiça Estadual de São Paulo - $1^{\mathbf{O}}$ grau

Local: Pindamonhangaba/Taubaté

Processo: $234 / 1867$

Destinatários:

Autor: Benedicto (escravo) por seu curador

Réu: Antonio Galvão de França Costa

Data: 23 de maio de 1876

Juiz: Antonio Joaquim Rodrigues

Descrição: 4 fólios- páginas 68 verso, 69 recto e verso, 70 recto, anotados por apenas um punho, o próprio juiz de direito proferidor da decisão. Trata-se de uma ação de liberdade intentada por um escravo, que fora batizado como livre, entretanto, encontrava-se na condição de escravo. Sentença que julga o autor carecedor da ação, em virtude de sentença anterior nulificando a certidão de batismo. 
DOC 1

64

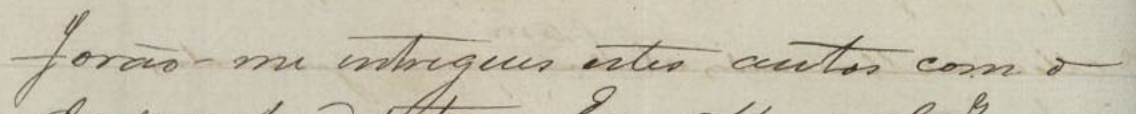

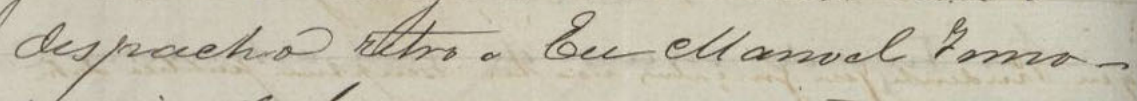

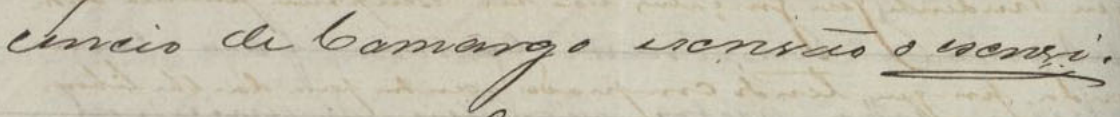

of bonclessas

-Ir dia dezoito de dlocis de mil outoento

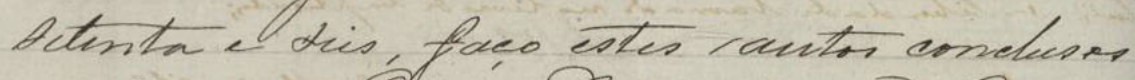
co quir de Quits Da Oonarea Foutr

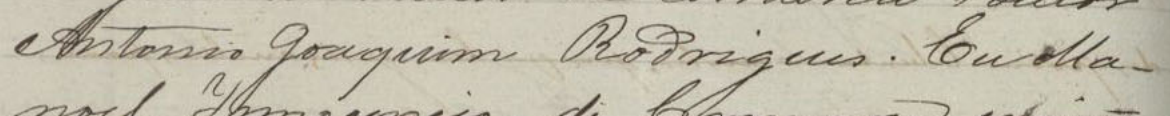

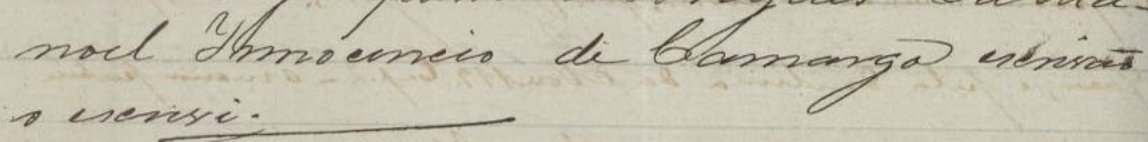

$\longrightarrow$ toncluesos

Vistas stes auts. COllega oescrars Bendicto fam in

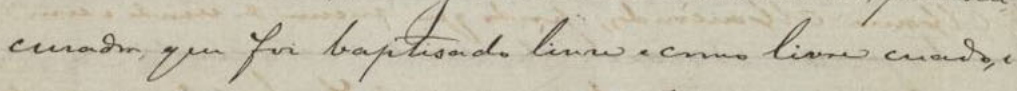

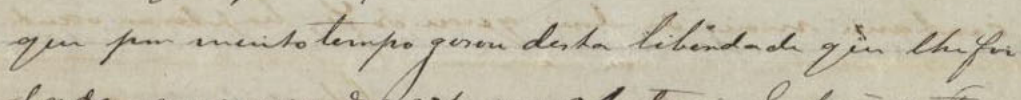

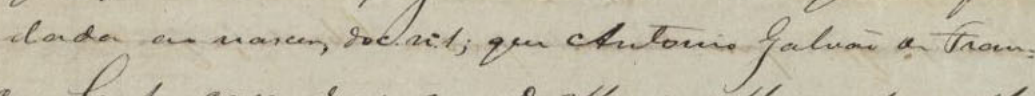

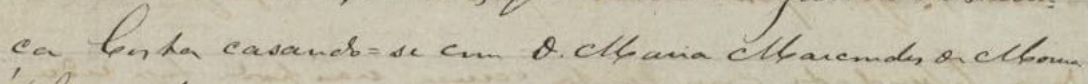

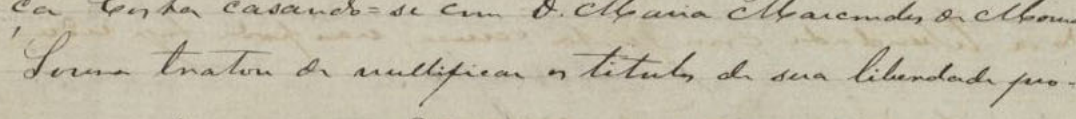

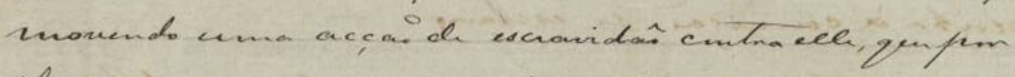

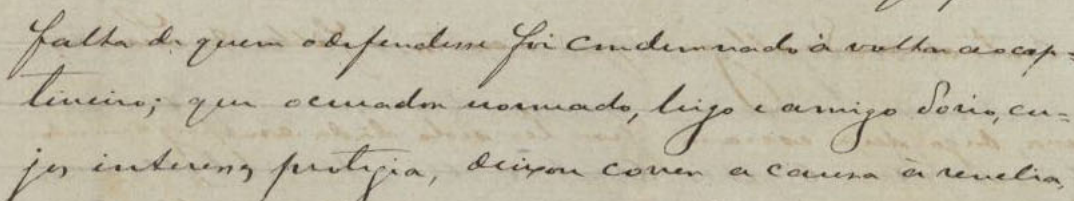

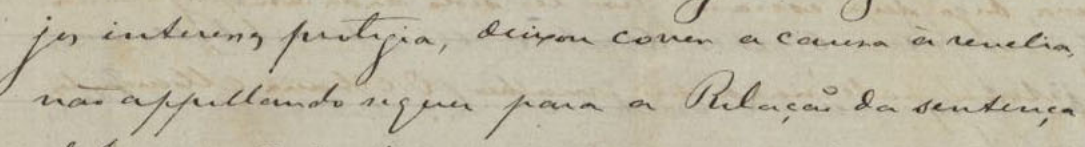

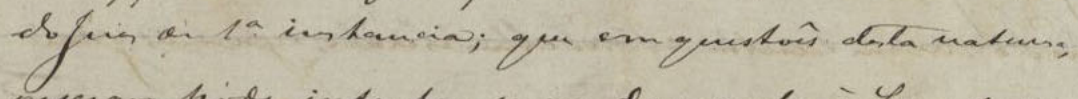

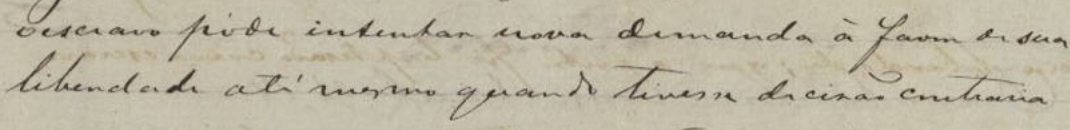

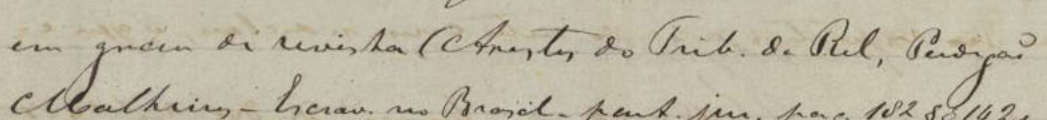

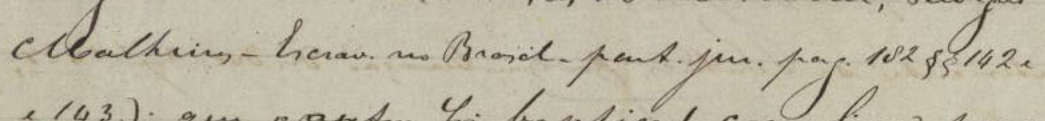

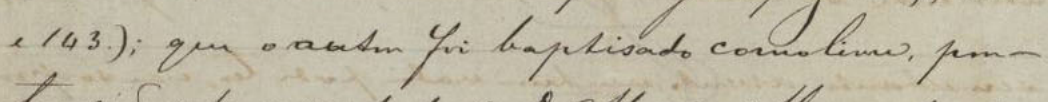

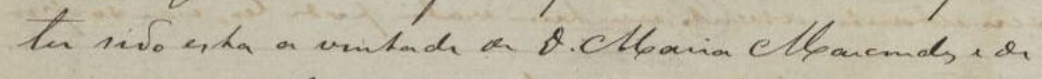

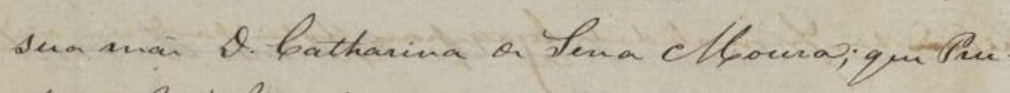

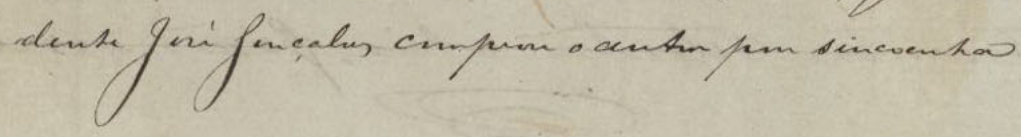




\section{Fólio $68 \mathrm{~V}^{1}$}

Vistos estes autos. Allega o escravo Benedicto, por seu curador, que foi baptisado livre e como livre criado, e que por muito tempo gosou desta liberdade que lhe foi dada ao nascer, documento numero 1; que Antonio Galvaõ de Fran=

5 ça Costa casando = se com Dona Maria Marcondes de Moura

Sousa tratou de nullificar os titulos de sua liberdade promovendo uma acçaõ de escravidaõ contra elle, que por falta de quem o defendesse foi condenado à voltar ao captiveiro; que o curador nomeado, leigo e amigo Socio, cujos interesses protegia, deixou correr a causa à revelia, naõ appellando se quer para a Relaçaõ da sentença do Juiz de $1^{\mathrm{a}}$ instancia; que em questoẽs desta natureza, o escravo pode intentar nova demanda à favor de sua liberdade até mesmo quando tivesse decisaõ contraria em grau de revista (Arestos do Tribunal da Relação, Perdigaõ Malheiros - Escravidão no Brasil - parte Jurídica pagina $182 \S \S 142 \mathrm{e}$ e 143); que o autor foi baptisado como livre, por ter sido esta a vontade de Dona Maria Marcondes e de sua mãe Dona Catharina de Lima Moura; que Prudente José Gonçalves comprou o autor por sincoenta

\footnotetext{
${ }^{1}$ Este fólio possui, em sua primeira metade, anotações de terceiro, que não foram editadas.
} 
miler para. firm or likentationa fia baptismal, equr W. Clbaria clbarcments unden so fum sen jesto valm;

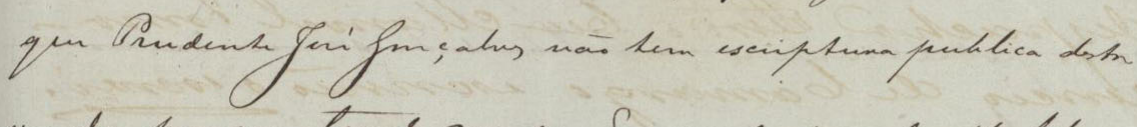

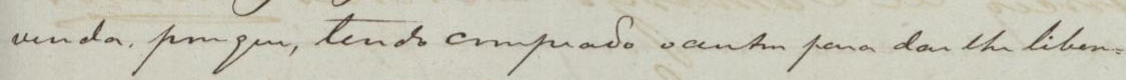

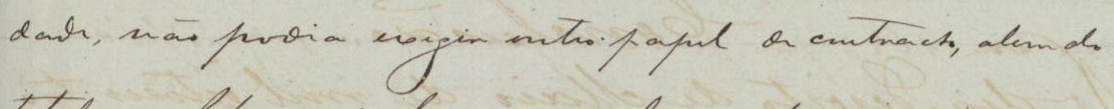

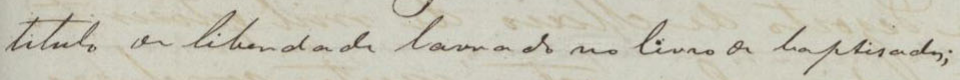

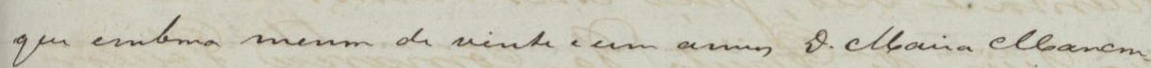

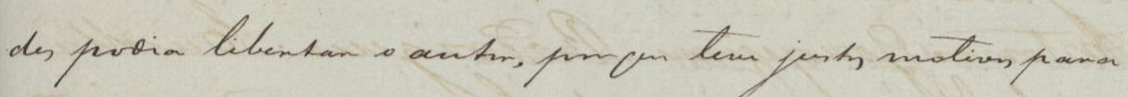

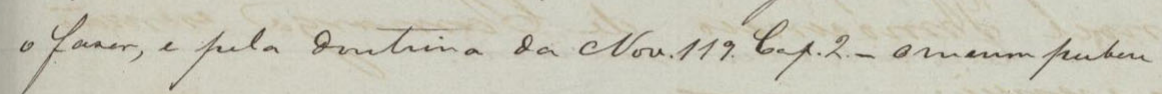

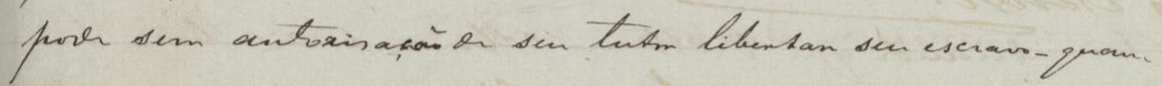
of fara iss haya camsa justa,

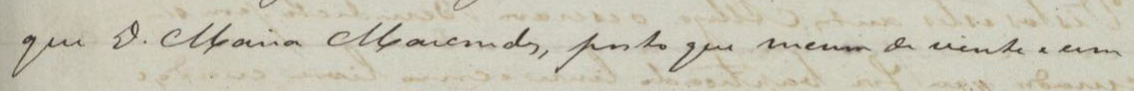

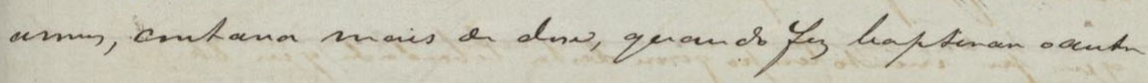

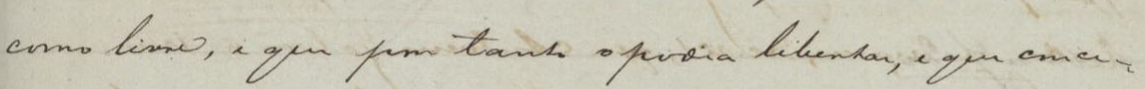

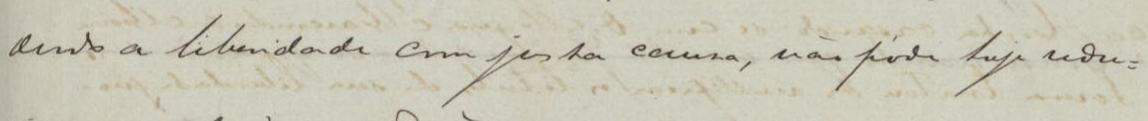

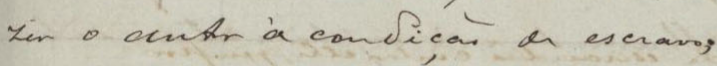

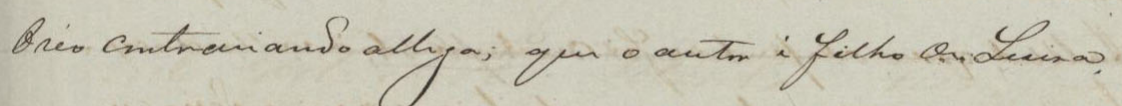
escrana, digo sua escrana from tex sido dada em fay aments ar hyitura faterna à sua mather O. Clbouin Cllouands,

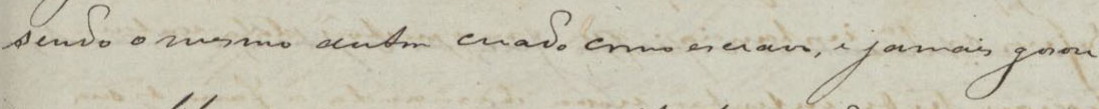
de suar libendade, quen o antm Li haptisado corno escravs,

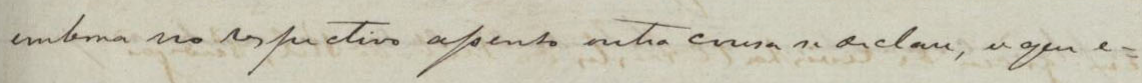

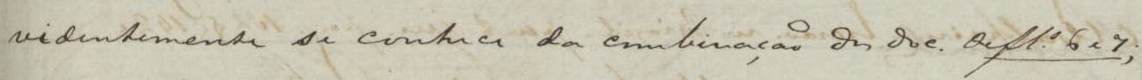

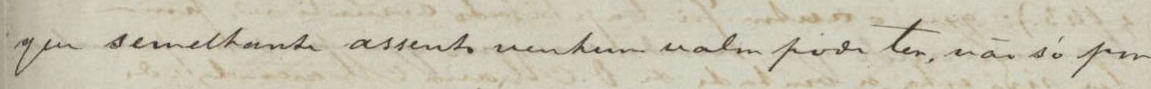

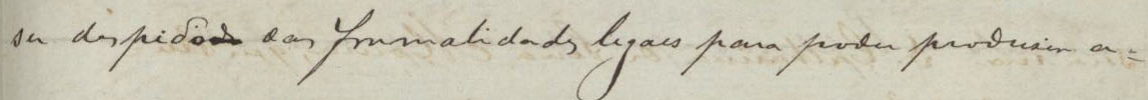


Fólio 69R

miles para o fim de libertal $=$ o na pia baptismal, e que

Dona Maria Marcondes vendeu=o por seu justo valor;

que Prudente José Gonçalves naõ tem escriptura publica desta venda porque, tendo comprado o autor para dar lhe liber $=$

5 dade, não podia exigir outro papel de contracto, alem do titulo de liberdade lavrado no livro de baptisados; que embora menor de vinte e um annos, Dona Maria Marcon= des podia libertar o autor, porque tem justos motivos para o fazer, e pela doutrina da (Novvembro) 119 Capítulo 2- o menor puberi 10 pode sem autorisaçaõ de seu tutor libertar seu escravo - quan= do para isso haja causa justa; que Dona Maria Marcondes, posto que menor de vinte e um annos, contava mais de dose, quando fez baptizar o autor como livre, e que por tanto o podia libertar, e que conce= dendo a liberdade com justa causa, naõ pode Juiz redu= zir o autor à condição de ecravo;

O réo contrariando allega; que o autor é filho de Luisa escrava, digo sua escrava por ter sido dada em pagamento de legitima paterna à sua mulher Dona Maria Marcondes, 20 sendo o mesmo autor criado como escravo, e jamais gosou de sua liberdade; que o autor foi baptisado como escravo, embora no respectivo assento outra cousa se declarou, e que e $=$ videntemente se conhece da combinação dos documentos de folhas 6 e 7; que semelhante assento nenhum valor pode ter, não só poe 25 ser despido(s) das formalidades legais para poder produzir $\mathrm{a}=$ 


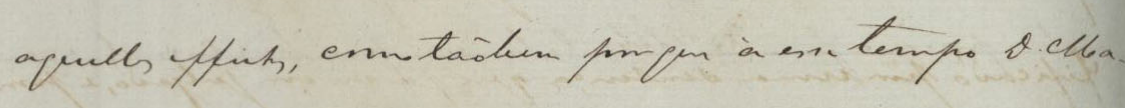

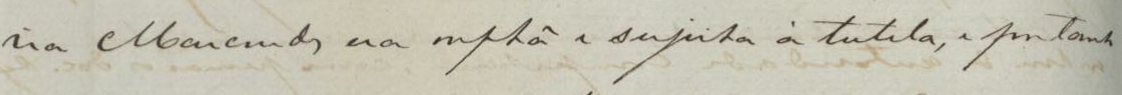
nà fuvira cmentien nesia libendar or sem cenisiencia os oen tutm icmentimento or foies or Ophain;

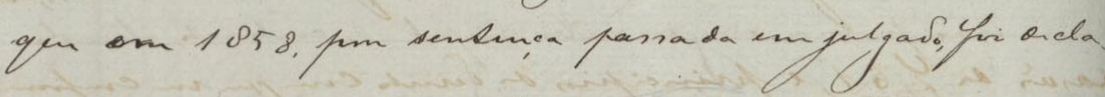

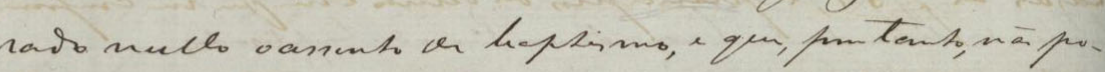

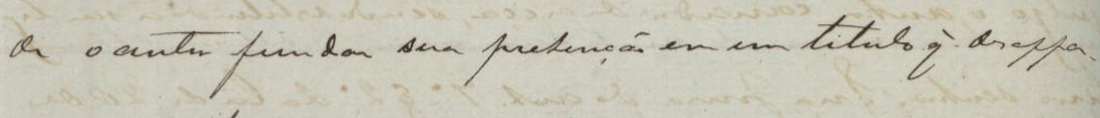
neso for Youca onguele senkenca.

Opur tuso visto i hem examinas:

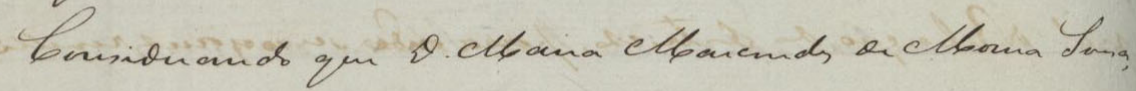

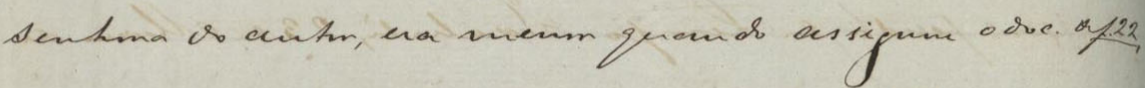

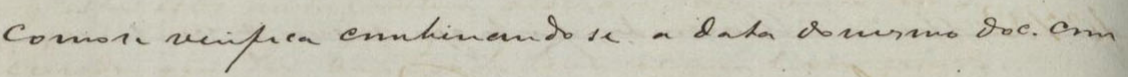

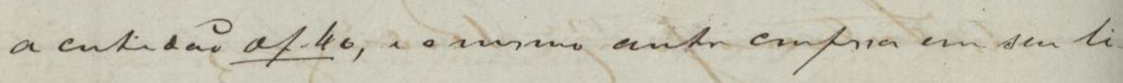
hall if $2 \cdot 2$;

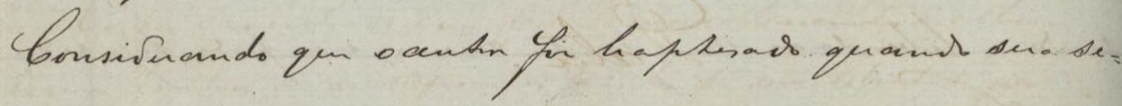

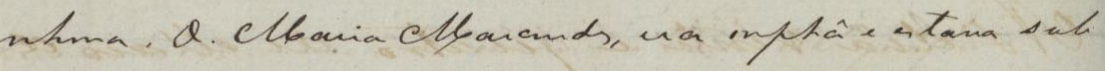
tutela, crmos si da cutidai a fer 34;

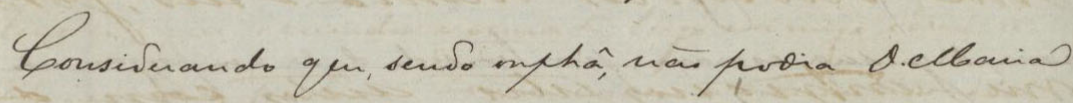

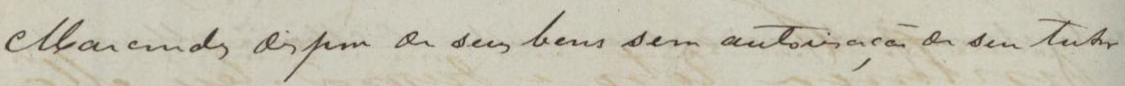

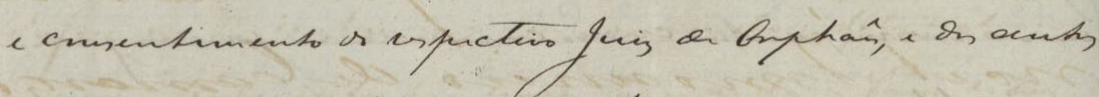

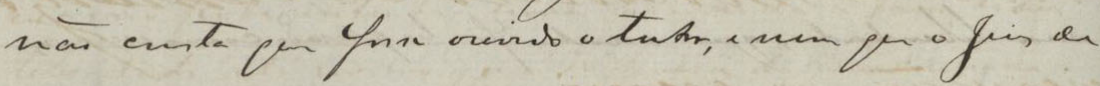

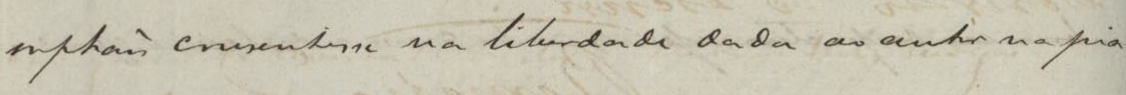
haptimal;

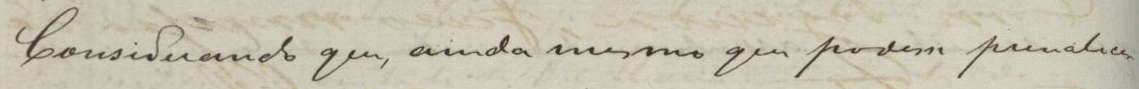

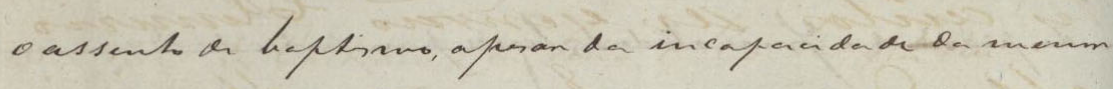


Fólio 69V

aquelles effeitos, como taõbem porque à esse tempo Dona $\mathrm{Ma}=$ ria Marcondes era orphã e sujeita à tutela, e portanto não podia consentir nessa liberdade sem audiencia de seu tutor e consentimento do Juiz de Orphaôs;

5 que em 1858, por sentença passada em julgado, foi decla= rado nullo o assento de baptismo, e que, por tanto, não po= de o autor fundar sua pretencaõ em um titulo que(ilegível) vicio por força daquella sentença O que tudo visto e bem examinado:

10 Considerando que Dona Maria Marcondes de Moura Sousa, senhora do autor, era menor quando assignou o documento de folha 22 , como se verifica combinando se a data do mesmo documento com a certidaõ defolha40, e o mesmo autor confessa em seu libello à folha 20;

15 Considerando que o autor foi baptisado quando sua senhora, Dona Maria Marcondes, era orphâ e estava sob tutela, como se vê da certidão afolhas 34 ; Considerando que, sendo orphâ, não podia Dona Maria Marcondes dispor de seus bens sem autorisação de seu tutor 20 e consentimento do respectivo Juiz de Orphaôs, e dos autos naõ consta que fosse ouvido o tutor, e nem que o Juiz de orphaõs consentisse na liberdade dada ao autor na pia baptismal;

Considerando que, ainda mesmo que pudesse prevalecer o assento de baptismo, apesar da incapacidade da mesma 
DOC 1

70

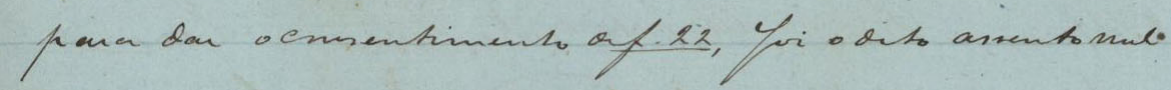

Yo

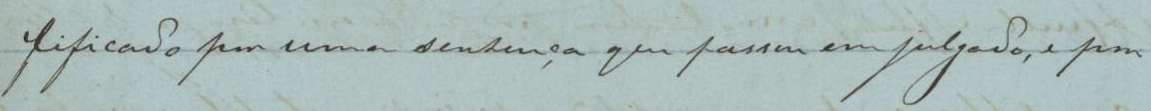

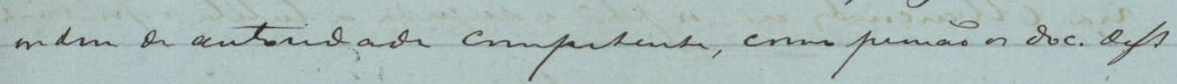

$35 \div 37=40$,

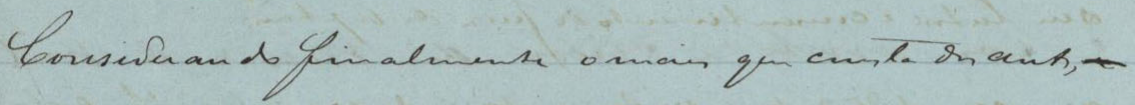

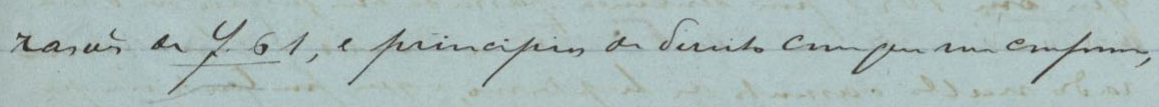

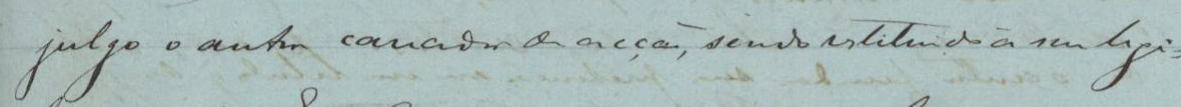

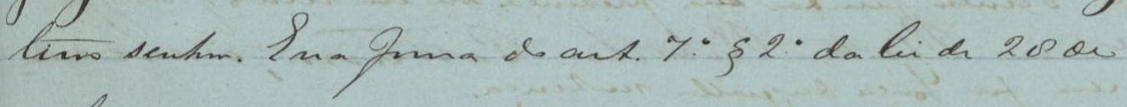

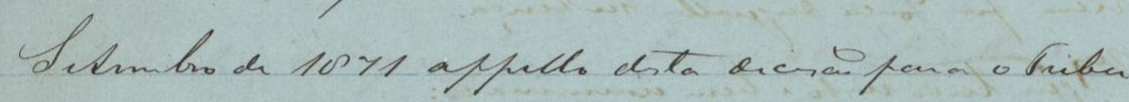

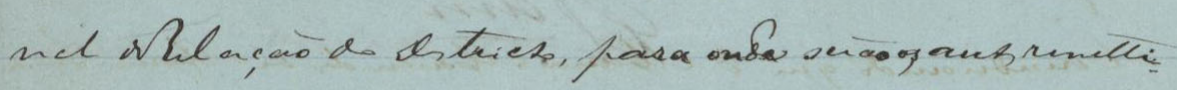

on perm ferda er temfo. Couhati; 23 ar Cllais or pry?

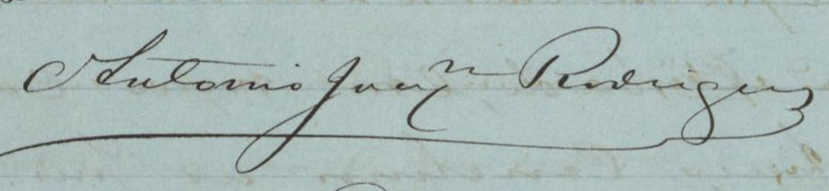

Dala.

Ofo dia vinte quatro de ellais de.

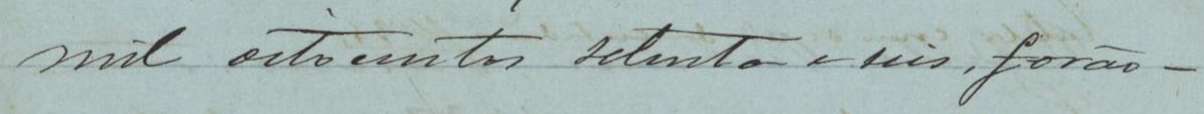

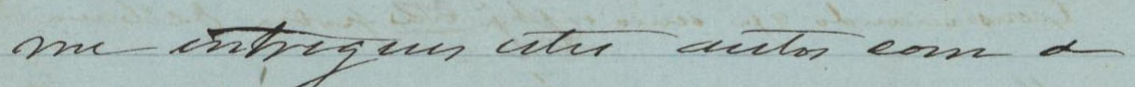

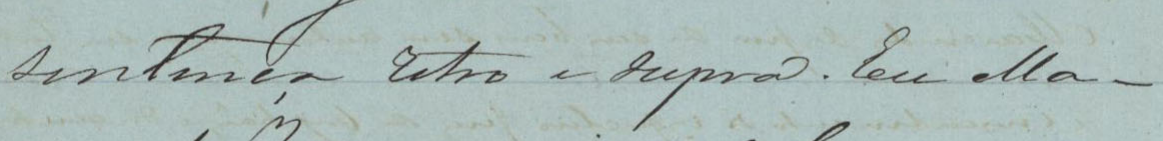

nout Imonerio de bannongr

vienstato eseni.

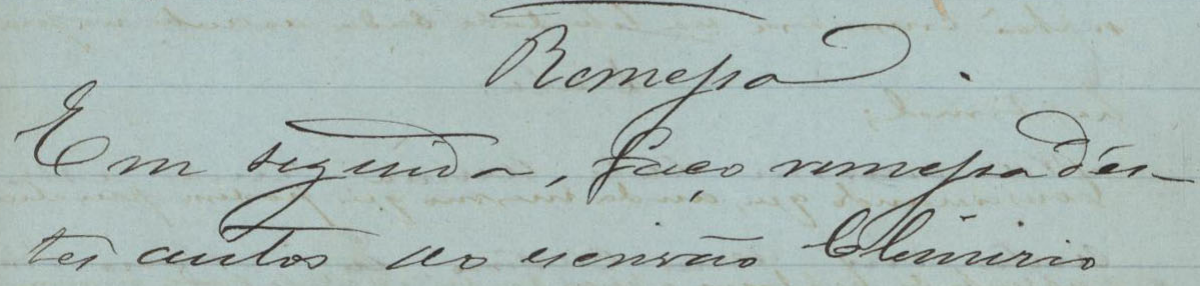

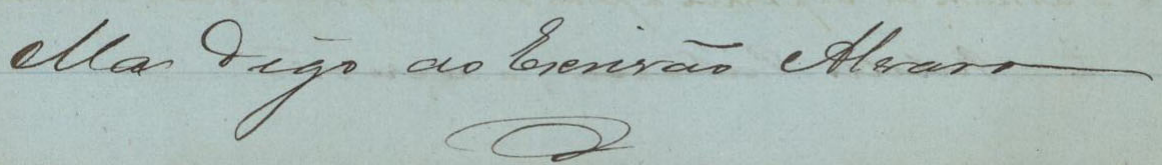


Fólio 70R

para dar o consentimento de folhas 22, foi o dito assento nul lificado por uma sentença que passou em julgado, e por ordem de autoridade competente, como primaõ os documentos de folhas 35 à 37 e 40;

5 Considerando finalmente o mais que consta dos autos, rasoẽs de folha 61, e principios de direito com (ilegível) enfim, julgo o autor carecedor da acçaõ, sendo restituido à seu legi= timo senhor. E na forma do artigo $7^{\underline{0}} \S 2^{\underline{O}}$ da lei de 28 de Setembro de 1871 appello desta decisão para o Tribu10 nal da Relação do Districto, para onde serão os autos remetti= dos sem perda de tempo. Taubaté, 23 de Maio de 1876.

\section{Antonio Joaquim Rodrigues ${ }^{2}$}

2 Este fólio possui, em sua metade final, anotações de terceiro, que não foram editadas. 


\section{$4.3 \quad$ DOC 2}

Documento: Acórdão (Relatório e Decisão)

Remetentes: juízes desembargadores representando a Justiça Estadual de São Paulo Tribunal da Relação $-2^{\underline{O}}$ grau

Local: São Paulo

Processo: 234/1867

Destinatários:

Apelante: o Juízo de Direito ex-ofício representando Benedicto (escravo)

Apelado: Antonio Galvão de França Costa

Data: 13 de abril de 1877 ( $1^{\mathrm{O}}$ acórdão) e 20 de julho de 1877 ( $2^{\mathrm{O}}$ acórdão)

Desembargador Relator: Luis Barbosa Accioli de Brito (responsável pelos dois Relatórios) Descrição: 7 fólios- páginas 76 verso, 77 recto e verso, 78 recto, 90 recto e verso, 91 recto, sendo o relatório de um só punho, os votos pelos punhos dos respectivos desembargadores responsáveis, e a decisão pelo punho do desembargador Luis Barbosa Accioli de Brito. Trata-se de uma ação de liberdade intentada por um escravo, que fora batizado como livre, entretanto, encontrava-se na condição de escravo. Sentença que julga o autor carecedor da ação, em virtude de sentença anterior nulificando a certidão de batismo. O juízo, ex ofício, recorre da decisão, que num primeiro acórdão determina a manifestação do curador, e em segundo julgamento, o novo acordão reforma a sentença para restituir a liberdade ao apelado. 


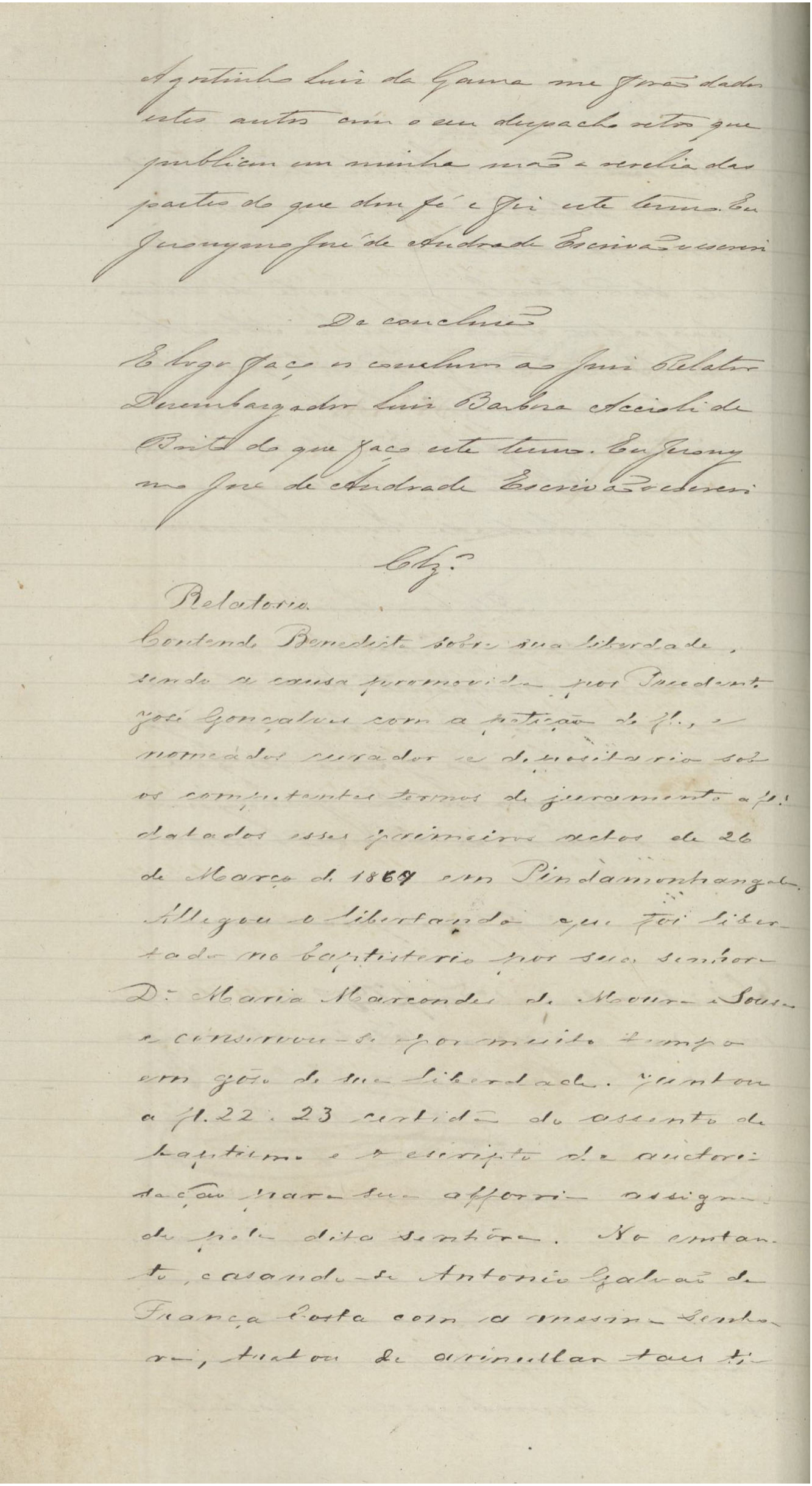




\section{Fólio $76 \mathrm{~V}^{3}$}

\section{Relatorio}

Contende Benedicto sobre sua liberdade, sendo a causa promovida por Prudente José Gonçalves com a petiçaõ de folhas, e

5 nomeados curador e depositario sob os competentes termos de juramento a folhas datados esses primeiros actos de 26 de Março de 1869 em Pindamonhangaba. Allegou o libertando que foi liber10 tado no baptisterio por sua senhora Dona Maria Marcondes de Moura e Sousa e conservou-se por muito tempo em góso de sua liberdade. Juntou a folhas 22 e 23 certidaõ do assento de baptismo e o escripto de auctorisaçaõ para sua alforria- assignado pela dita senhóra. No entanto, casando-se Antonio Galvaõ de França Costa com a mesma Senho20 ra, tratou de annullar tais ti-

${ }^{3}$ Este fólio possui, em sua primeira metade, anotações de terceiro, que não foram editadas. 


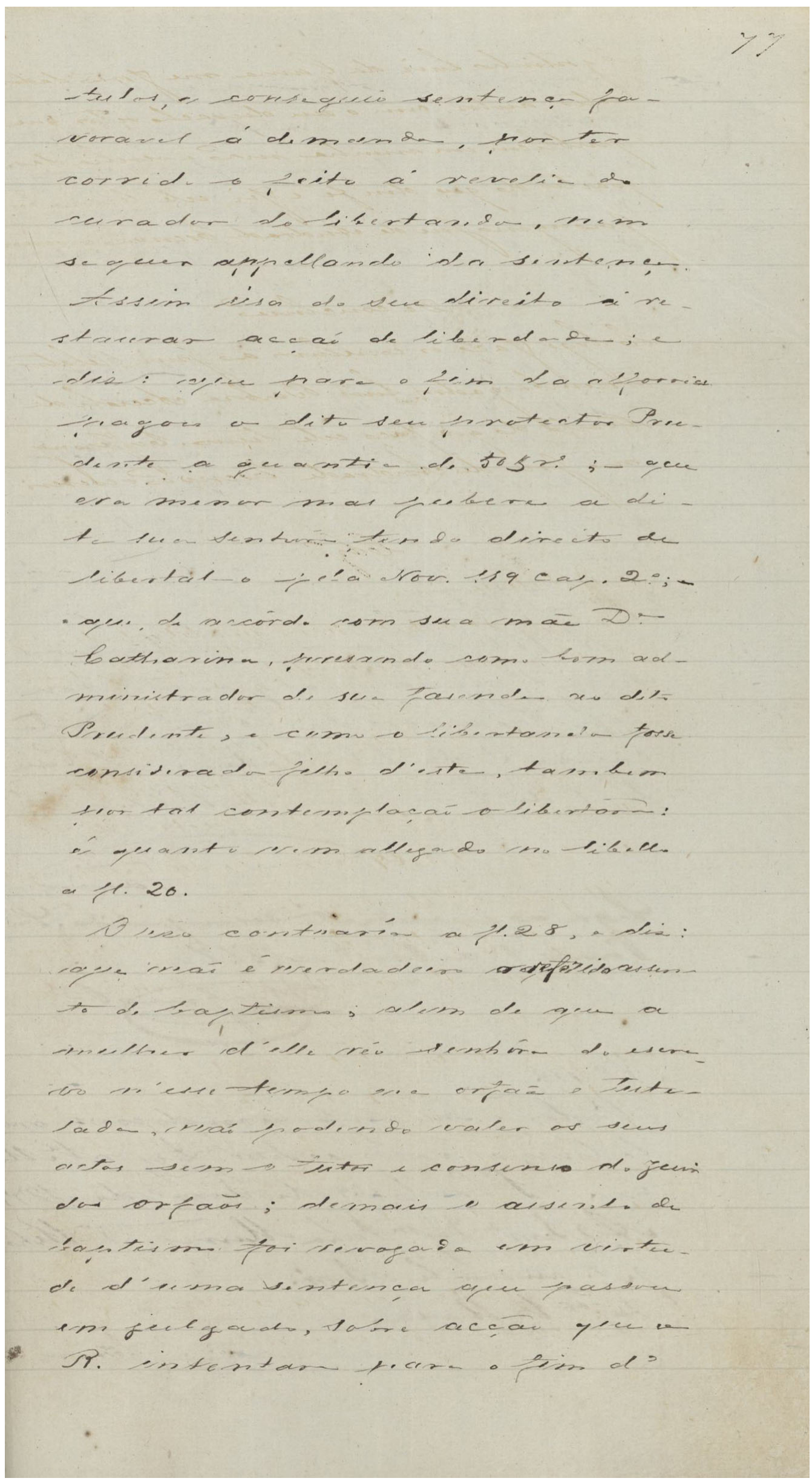


Fólio 77R

tulos, e conseguiu sentença favoravel á demanda, por ter corrido o feito á revelia do curador do libertando, e nem 5 se quer appellando da sentença. Assim visa do seu direito á restaurar acçaõ de liberdade; e dis: que para o fim da alforria pagou o dito seu protector Prudente a quantia de (505.000); - que era menor mas pubere a dita sua senhora tendo direito de libertal-o pela (Nov) 119 capítulo 2º;que de accôrdo com sua maẽ Dona 15 Catharina, pesando como bom administrador de sua fasenda ao dito Prudente, e como o libertando fosse considerado filho d'este, tambem por tal contemplaçaõ o libertando:

20 á quanto vem allegado no libello a folhas 20 .

O reo contraría a folhas 28 , e dis: que naõ é verdadeiro o referido assento de baptismo; alem de que a 25 mulher d'elle réo senhóra do escravo nesse tempo era orfaõ e tutelada, naõ podendo valer os seus actos sem o tutor e consenso do juiz dos orfaõs; demais o assento de baptismo foi revogado em virtude de uma sentença que passou em julgado, sobre acçã̃ que o Réu intentou para o fim d'- 
DOC 2

77

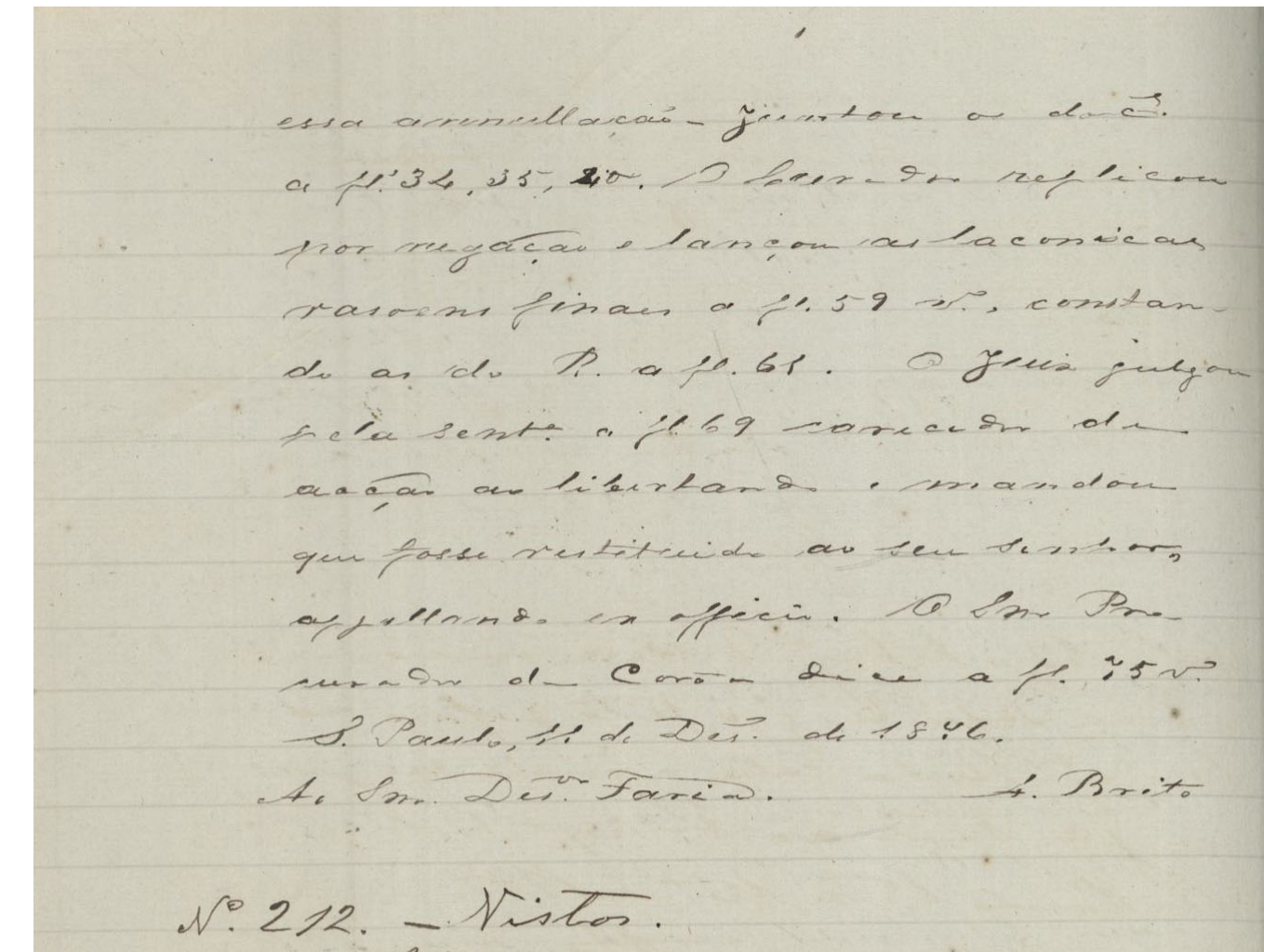

A Mrega, fraron providenciar vobre ti ravior, for geranto an Loje Pracuradr da Corôa, a erta

lo, de ferveris: de 18\%y.
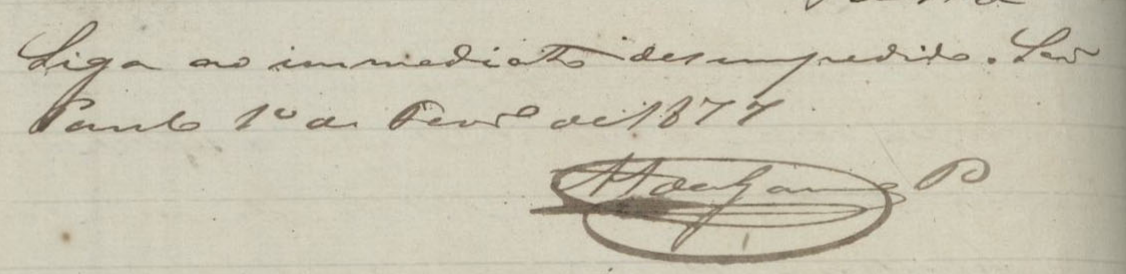

So 118

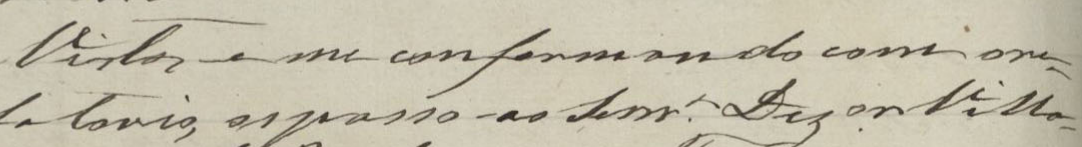

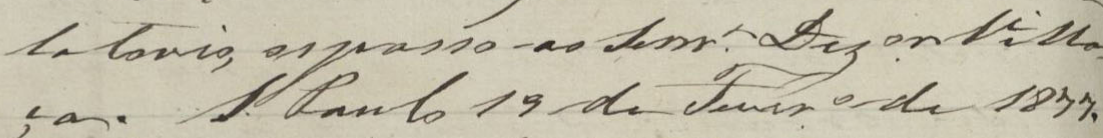

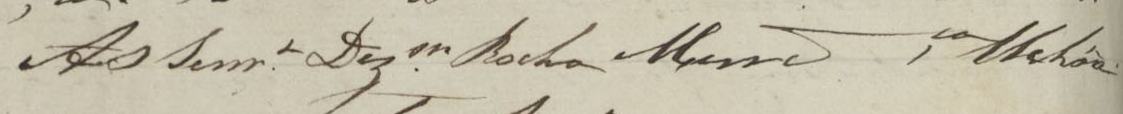
in 3 ase ex ho Somí

Sugen is llaya. 
Fólio $77 \mathrm{~V}$

essa annullaçaõ - Juntou os documentos

a folhas 34, 35, 40. O Curador replicou

por negaçaõ e lançou as laconicas

rasoens finaes a folhas 59 verso, constan-

5 do as do Réu a folhas 61 . O Juiz julgou

pela sentença a folhas 69 carecedor de

acçaõ o libertando e mandou

que fosse restituido ao seu senhor,

appellando ex officio. O Excelentíssimo Pro-

10 curador da Corôa disse a folhas 75 verso.

Saõ Paulo, 11 de Dezembro de 1876

Ao Senhor Desembargador Faria Luis Barbosa Accioli de Brito ${ }^{4}$

${ }^{4}$ Este fólio possui, a seguir, anotações de terceiro, que não foram editadas. 
DOC 2

79

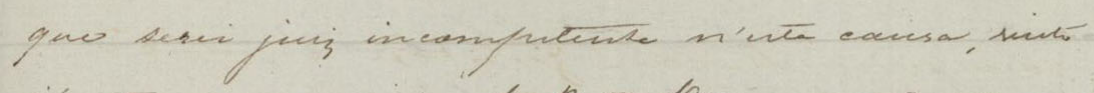

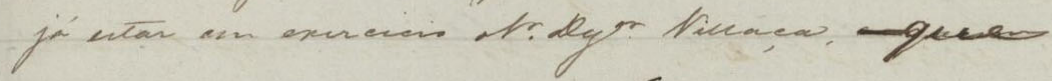

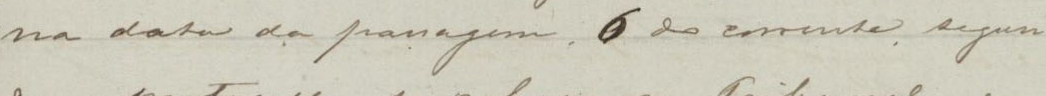

to " protreack, te acherr m fribunal, i

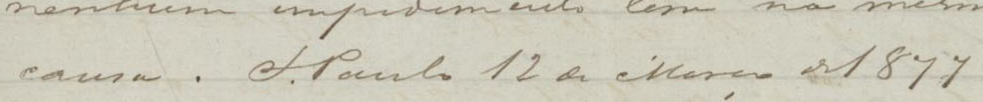

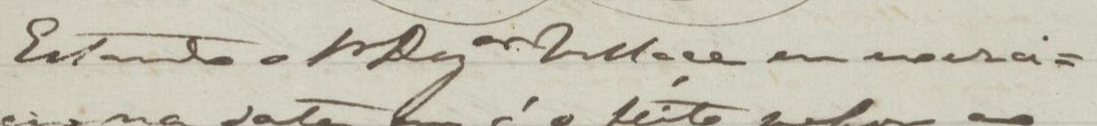

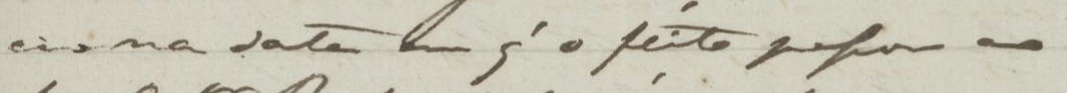

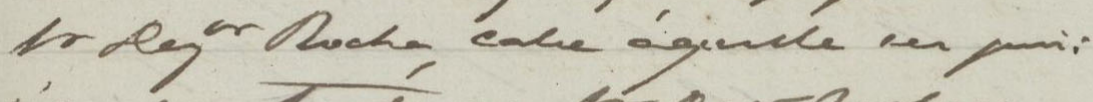

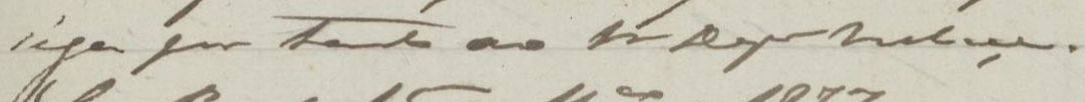

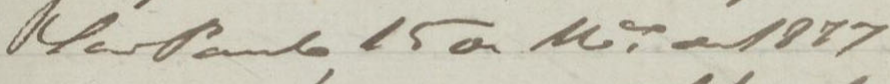

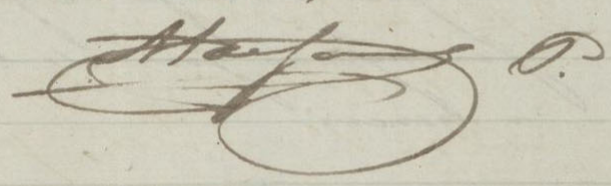

1.9596-

Listos: Bon farmo me con o Th tabio. Sou bo 12 denthilch 1812

SPelelace

Alitbua

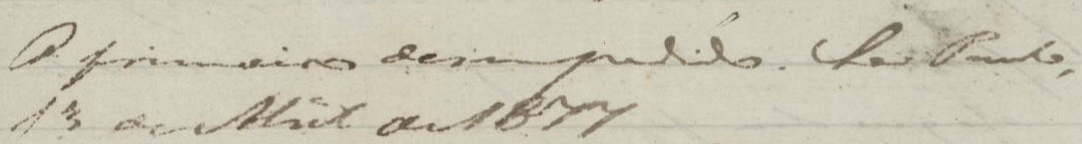

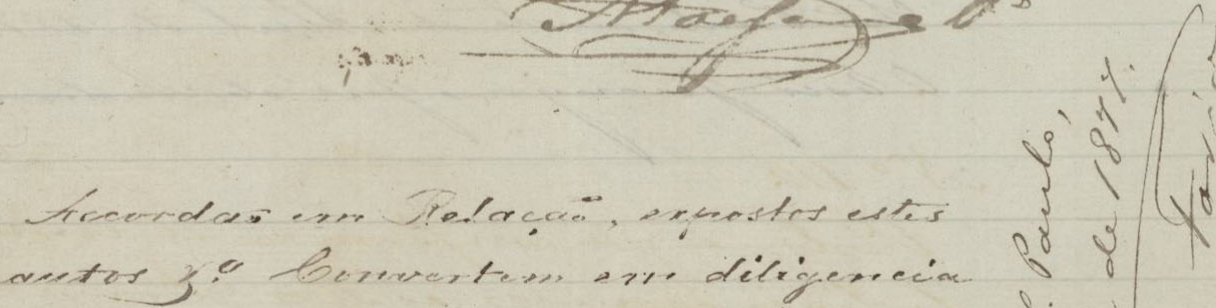

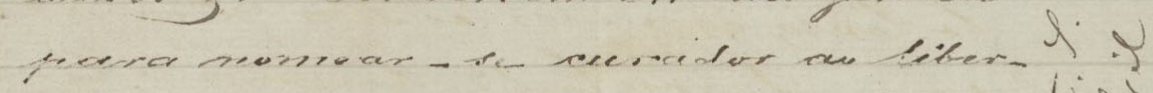

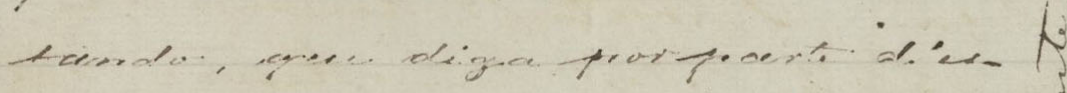

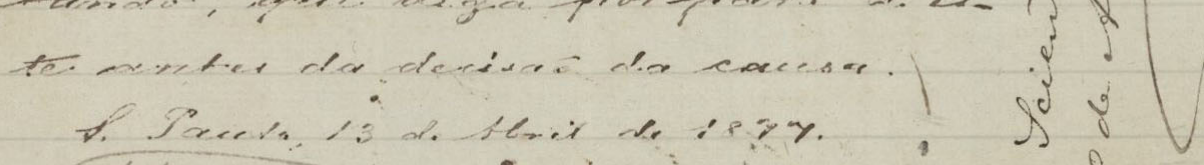

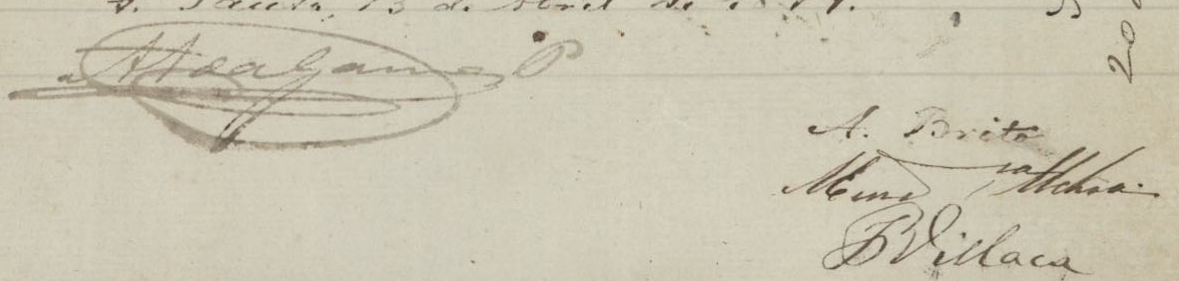


Fólio 78R

Número 576

Vistos: Conformo-me com o Re-

latorio. Saõ Paulo 12 de Abril de

1877 À Mesa

5 Joaquim Pedro Villaça ${ }^{5}$

Accordaõ em Relaçaõ, expostos estes

autos; Convertem em diligencia

para nomear-se curador ao liber-

10 tando, que diga por parte d'es-

te antes da decisaõ da causa.

Saõ Paulo, 13 de abril de 1877.

Agostinho Luiz da Gama

A. Brito

15

Mendonça Uchôa

Joaquim Pedro Villaça

Sciente. Saõ Paulo,

20 de Abril de 1877.

Joaquim Francisco de Faria

${ }^{5}$ Este fólio possui, a seguir, anotações de terceiro, que não foram editadas 


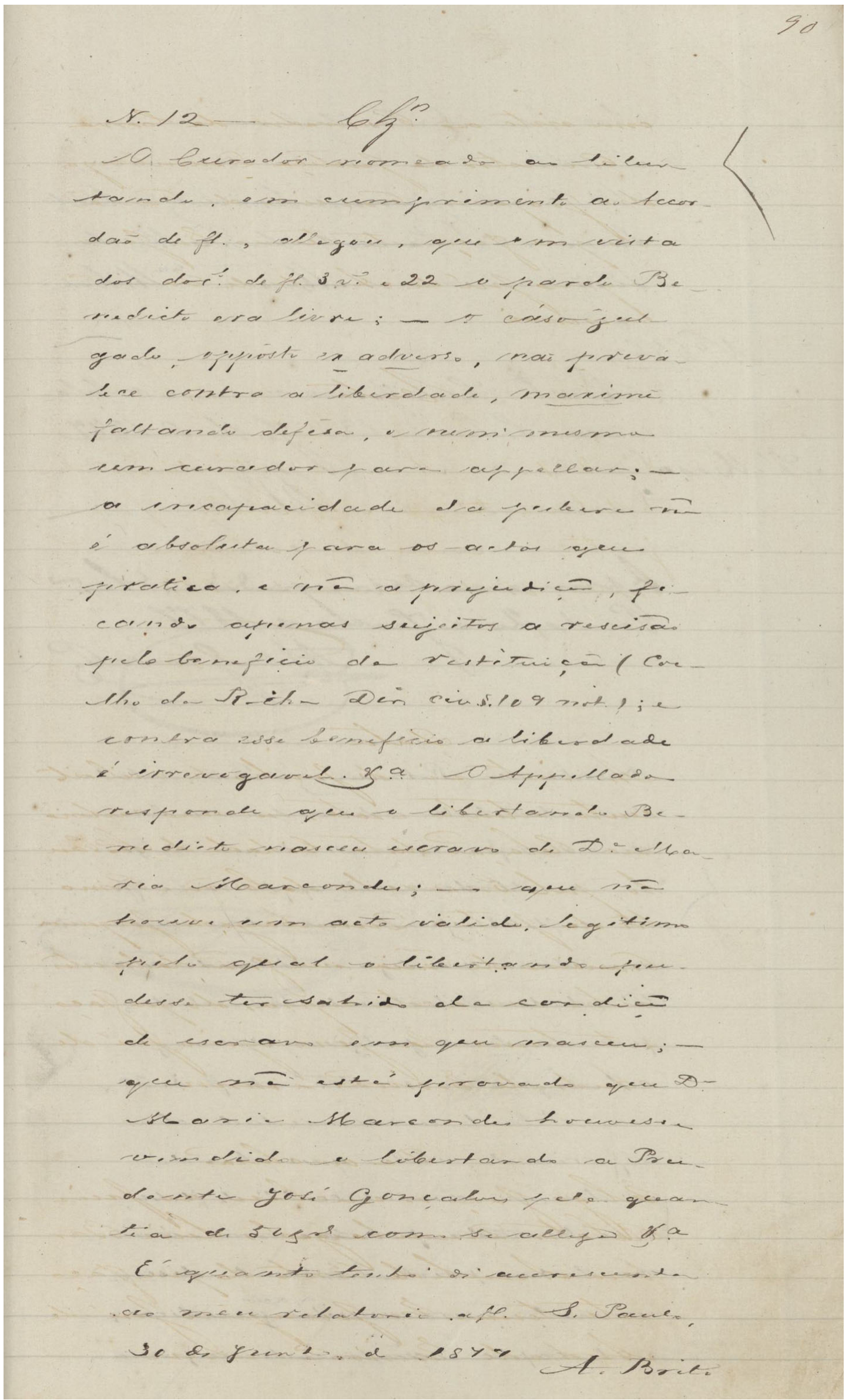


Fólio 90R

\section{Número 12 Concluzos}

O Curador nomeado do libertando, em cumprimento ao Accor-

daõ de folhas, allegou, que em vista

dos documentos de folhas 3 verso e 22 o pardo Be-

5 nedicto era livre: - o caso jul-

gado, opposto ex adversso, naõ preva-

lece contra a liberdade, maxime

faltando defesa, e nem mesmo

um curador para appellar; -

10 a incapacidade da pubere naõ

é absoluta para os actos que

practica, e naõ a prejudicaõ, fi-

cando apenas sujeitos a rescisaõ

pelo beneficio da restituiçaõ ( Coe-

15 lho da Rocha Direito Civil 109 (not); e

contra esse beneficio a liberdade

é irrevogavel. Vossa Senhoria O Appellado

responde que o libertando Be-

nedicto nasceu escravo de Dona Ma-

20 ria Marcondes; - que naõ

houve um acto valido, legitimo

pela qual o libertando pu-

desse ter sabido da condiçaõ

de escravo essa que nasceu; -

25 que naõ esta provado que Dona

Maria Marcondes houvesse

vendido o libertando a Pru-

dente José Gonçalves pela quan-

tia de 505.000 como se allega Vossa Senhoria.

É quanto tenho a acrescentar

ao meu relatorio afolhas. Saõ Paulo,

30 de junho de 1877.

\section{Luis Barbosa Accioli de Brito}




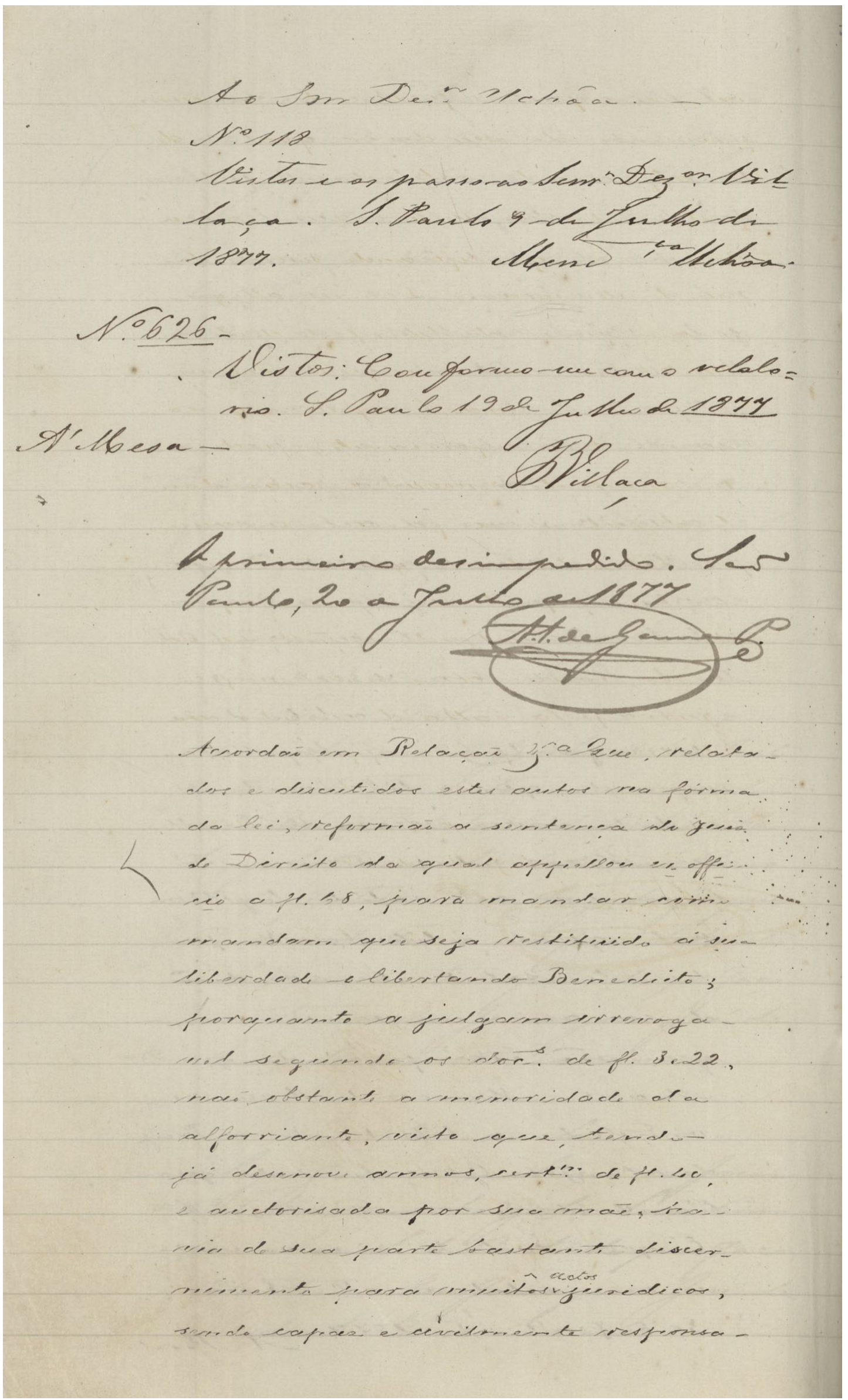


Fólio 90V

Ao Senhor Desembargador Rocha Mendonça Uchôa

Número 118

Vistos e os passo- ao Senhor Dezembargador Vil-

laça. Saõ Paulo 9 de julho de

51877.

\section{Rocha Mendonça Uchôa}

Número 626

Vistos. Conformo-me com o relato-

rio. Saõ Paulo 19 de julho de 1877.

10 Á Mesa

\section{Villaça ${ }^{6}$}

Accordaõ em Relaçaõ (ilegível), relatados e discutidos estes autos na forma

da lei, reformaõ a sentença do juiz

de Direito da qual appellou ex offi-

cioa folhas 68 , para mandar como

mandam que seja restituido à sua

liberdade o libertando Benedicto;

20 porquanto a julgam irrevoga-

vel segundo os documentos de folhas 3 e 22 ,

naõ obstante a menoridade da

alforriante, visto que, tendo

já desenove annos, certidaõ de folhas 40,

e auctorisada por sua maẽ, tra-

zia de sua parte bastante discer-

nimento para muitôs actos juridicos,

sendo capaz e civilmente responsa-

${ }^{6}$ Este fólio possui, a seguir, anotações de terceiro, que não foram editadas. 


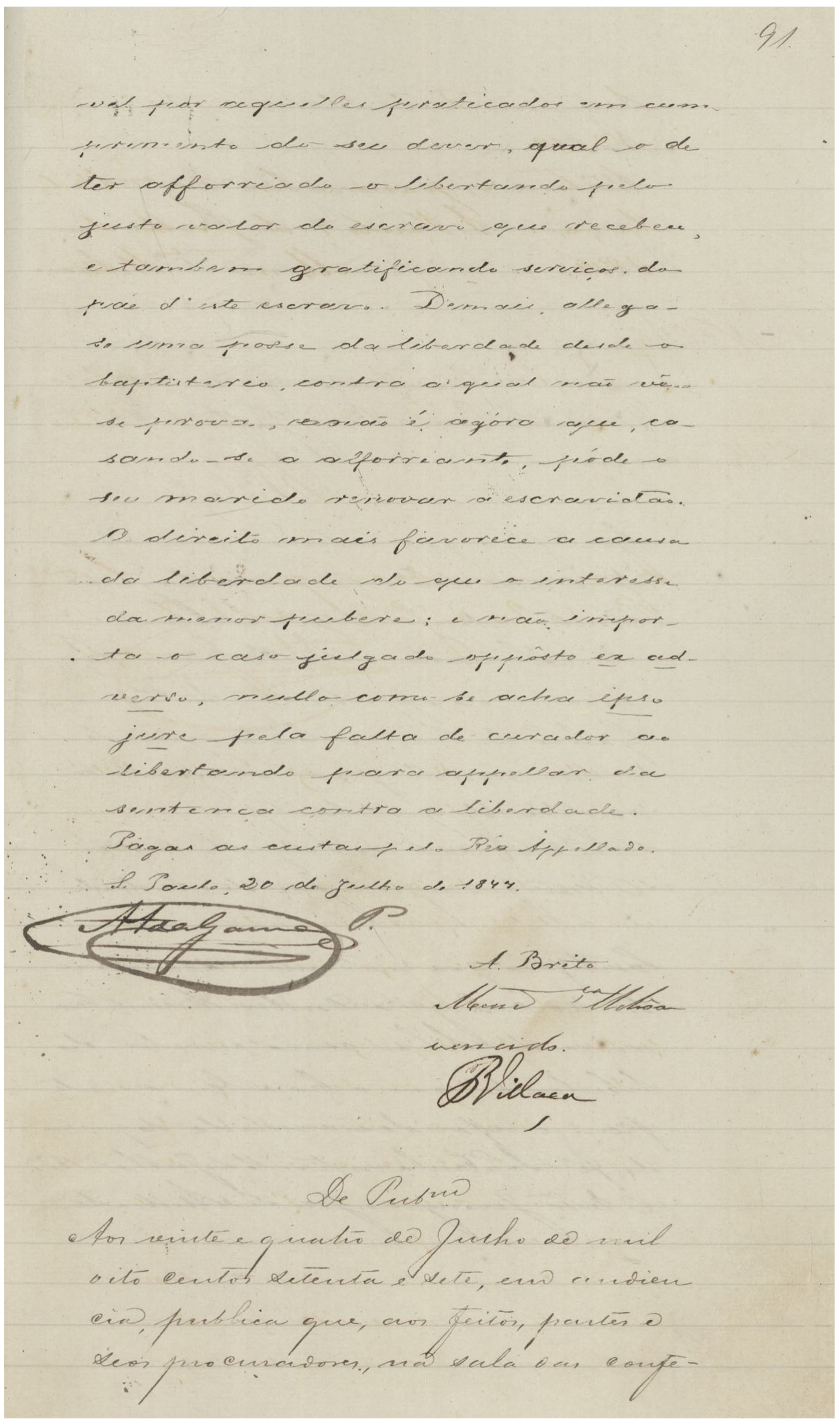


Fólio 91R

vel por aquelles praticados em cumprimento de seu dever, qual o de ter afforriado o libertando pelo justo valor de escravo que recebeu,

5 e tambem gratificando serviços da maẽ d'este escravo. Demais allegase uma posse da liberdade desde o baptisterio, contra o qual naõ vêm se provar, e naõ é agora que, ca-

10 sando-se a alforriante, póde o seu marido renovar a escravidaõ. O direito mais favorece a causa da liberdade do que o interesse da menor pubere: e naõ impor15 ta o caso julgado oppôsto ex ad$\underline{\text { verso, }}$ nullo como se acha ipso jure pela falta de curador do libertando para appellar da sentença contra a liberdade.

20 Pagas as custas pelo Réo Appellado. Saõ Paulo, 20 de julho de 1877.

Agostinho Luis da Gama

\section{A Brito}

\section{José de Mendonça Uchôa}

25 vencido

\section{Villaça ${ }^{7}$.}

\footnotetext{
${ }^{7}$ Este fólio possui, a seguir, anotações de terceiro, que não foram editadas
} 


\section{$4.4 \quad$ DOC 3}

Documento: Sentença

Remetente: juiz ordinário representando a Justiça Estadual de São Paulo - $1^{0}$ grau

Local: São Paulo

Processo: 03/1873

Data: 29 de Janeiro de 1874

Destinatários:

Autora: Emiliana Parda

Réu: Antonio Teixeira de Carvalho

Juiz: Antonio Candido da Rocha

Descrição: 4 fólios- páginas 32 recto e verso, 33 recto e verso, anotados por apenas um punho, o próprio juiz de direito proferidor da decisão. Trata-se de uma ação de liberdade intentada por uma escrava, que nascera de ventre-livre, porém encontrava-se na condição de escrava. Sentença que julga procedente o pedido da autora, confirmando sua situação de livre, em virtude do nascimento de mãe ex-escrava. 


\section{Q). Chm}

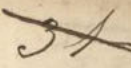

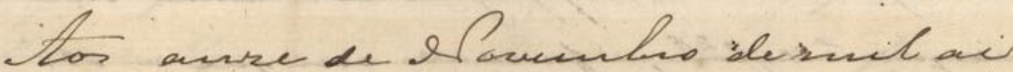

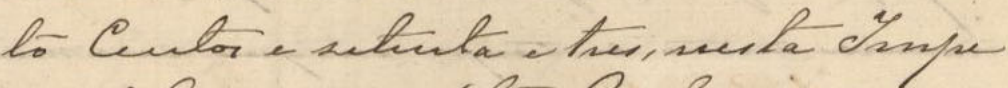

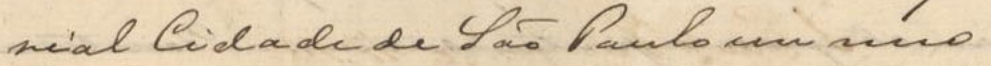

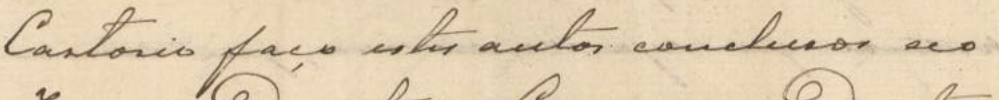

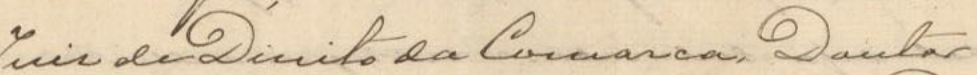

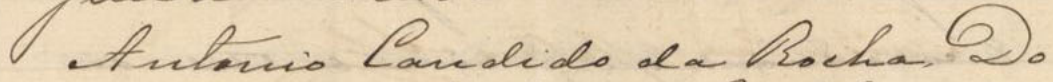

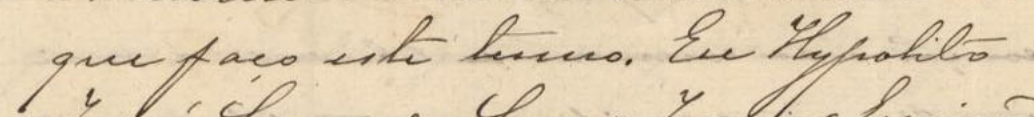

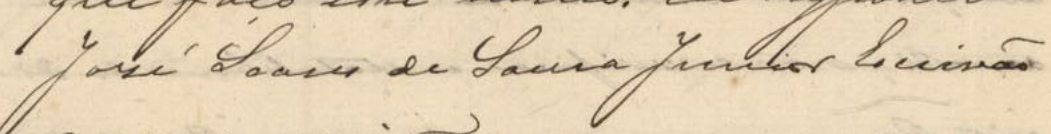

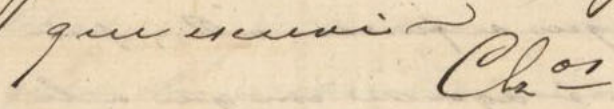

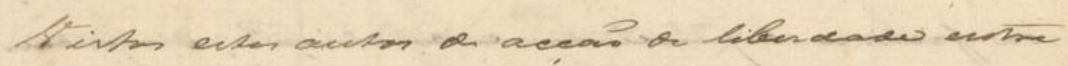

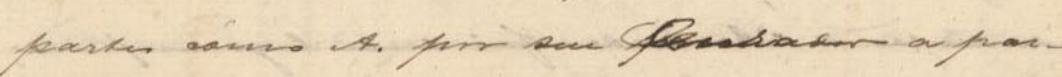

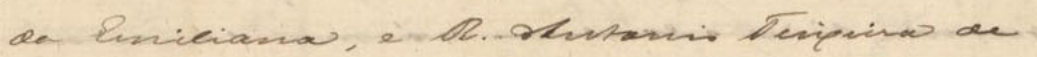
Cownach

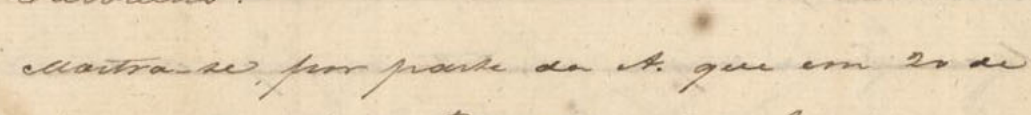

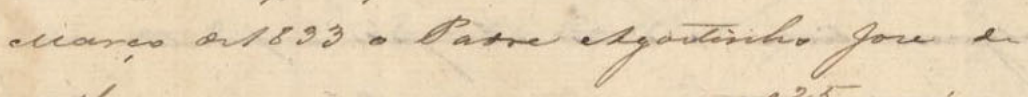

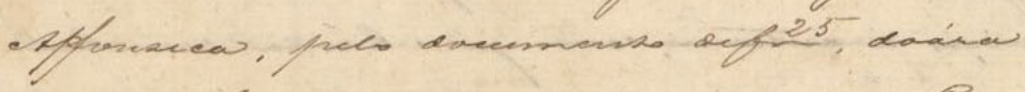

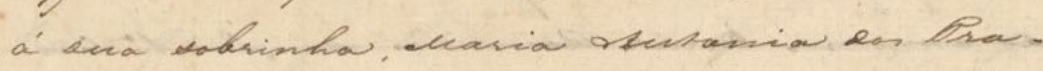

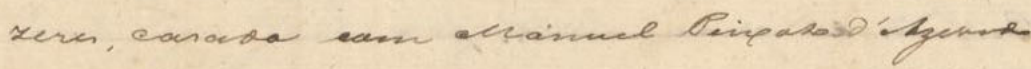

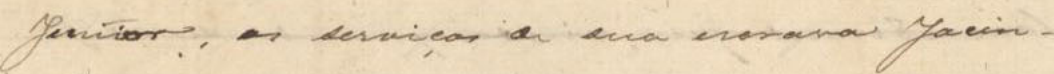
sha fur cypar a 23

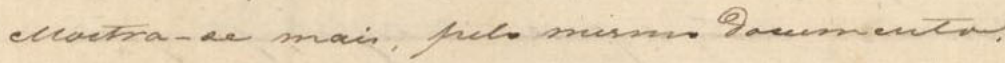

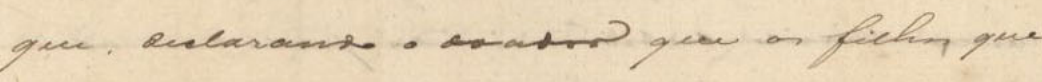

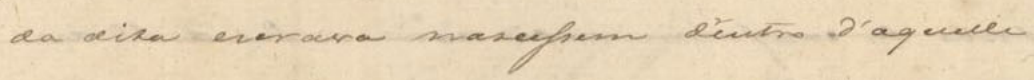

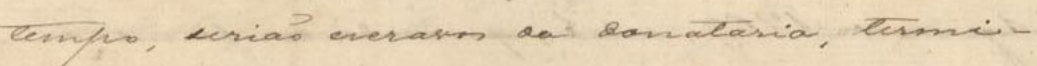

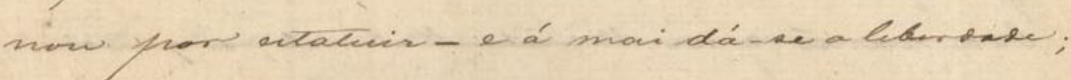

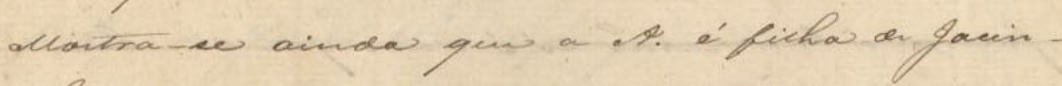

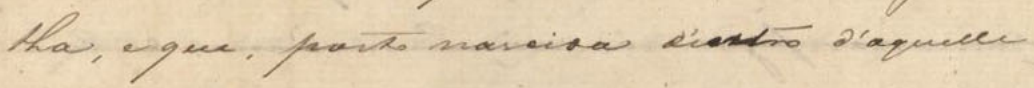

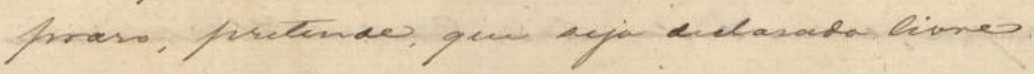

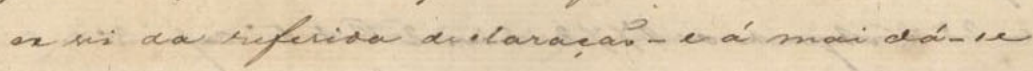
a Eiberdaxes. 
Fólio $32 \mathrm{R}^{8}$.

Vistos estes autos de acçaõ de liberdade entre partes como Autora por seu Curador a parda Emiliana, e Réu Antonio Teixeira de Carvalho:

5 mostra-se por parte da Autora que em 20 de março de1833 o Padre Agostinho Jose de Aphonseca, pelo documento defolhas 25, doara á sua sobrinha, Maria Antonia dos Prazeres, casada com Manuel Peixoto d'Azevedo

10 Junior, os serviços de sua escrava Jacintha por espaço de 23 annos; Mostra-se mais, pelo mesmo documento que declarando o doador que os filhos que da dita escrava nascessem dentro d'aquelle tempo, seriaõ escravos da donataria, terminou por estatuir - e á mai dá-se a liberdade; Mostra-se ainda que a Autora é filha de Jacintha, e que, pornaõ nascida dentro d'aquelle prazo, pretende que seja declarada livre 20 ex sic da referida declaraçaõ - e á mai dá-se a liberdade.

\footnotetext{
${ }^{8}$ Este fólio possui, em sua primeira parte, anotações de terceiro, que não foram editadas
} 


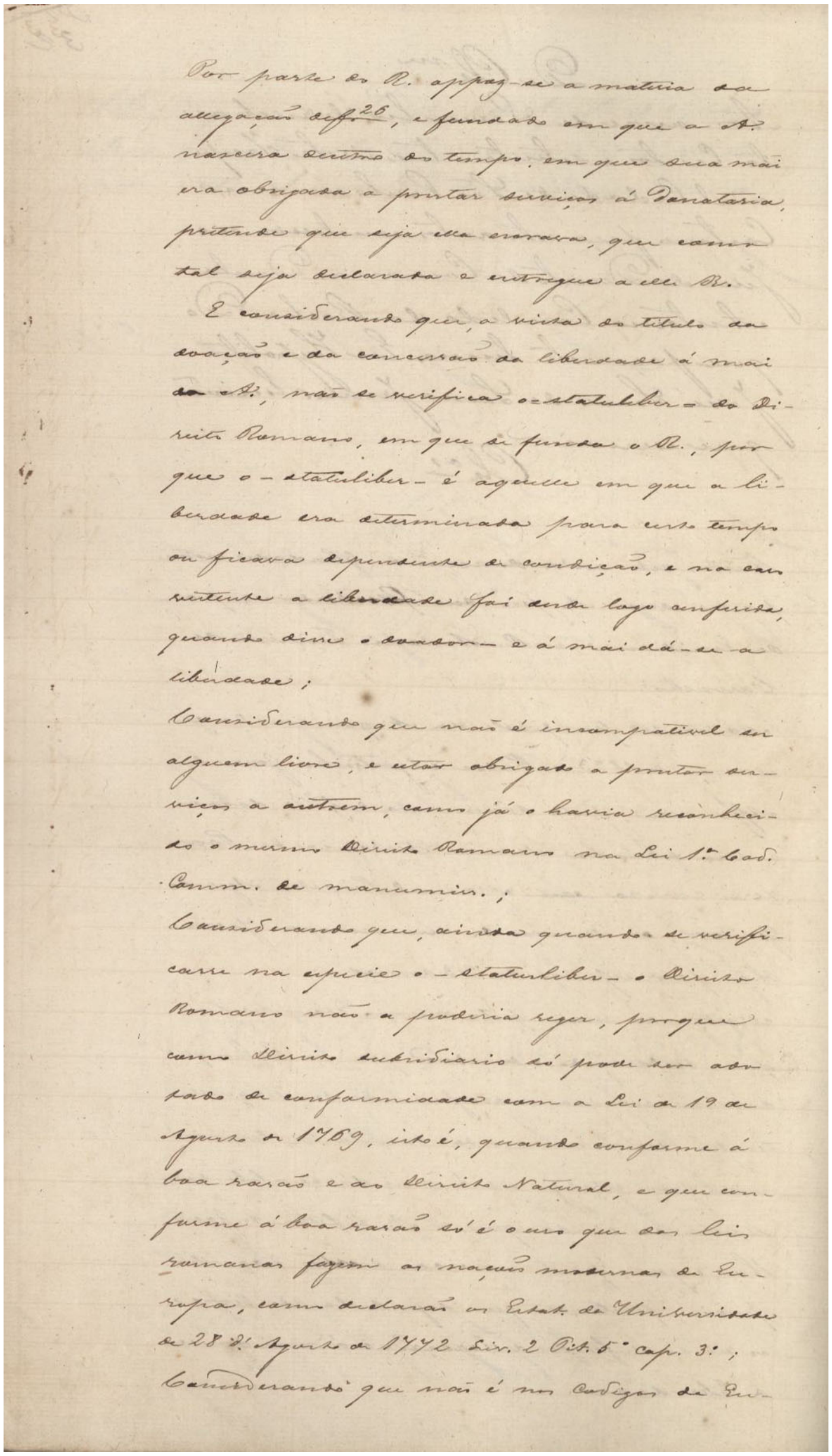


Fólio 32V

Por parte do Reu appraz-se a materia da allegaçaõ defolhas26, e fundado em que a Autora nascera dentro do tempo em que sua mai era obrigada a prestar serviços á Donataria, 5 pretende que seja ella escrava, que como tal seja declarada e entregue a elle Réu. E considerando que, a vista do titulo da doaçaõ e da concessaõ da liberdade á mai da Autora, não se verifica o $=$ statuliber $=$ do Direito Romano, em que se funda o Réu, por que o -statuliber- é aquelle em que a liberdade era determinada para certo tempo ou ficava dependente de condiçaõ, e no caso vertente a liberdade foi desde logo conferida, quando disse o doador - e à mai dá-se a liberdade;

Considerando que naõ é incompativel ser alguem livre, e estar obrigado a prestar serviços a outrem, como já o havia reconhecido o mesmo Direito Romano na Lei $1^{\mathrm{O}}$ Codigo Commercial de manumissão; Considerando que, ainda quando se verificasse na especie o - staturliber - o Direito Romano não a poderia reger, porque como Direito subsidiario só pode ser alegado de conformidade com a Lei de 19 de Agosto de 1769, isto é, quando conforme á boa rasaõ e ao Direito Natural, e que conforme á boa rasaõ só é o uso que das leis romanas fazem as naçoẽs modernas da Europa, como declaraõ os Estatutos da Universidade de 28 d'Agosto de 1772 Livro 2 Titulo $5^{\mathrm{O}}$ Capitulo $3^{\mathrm{O}}$; Considerando que naõ é nos Codigos da Eu- 


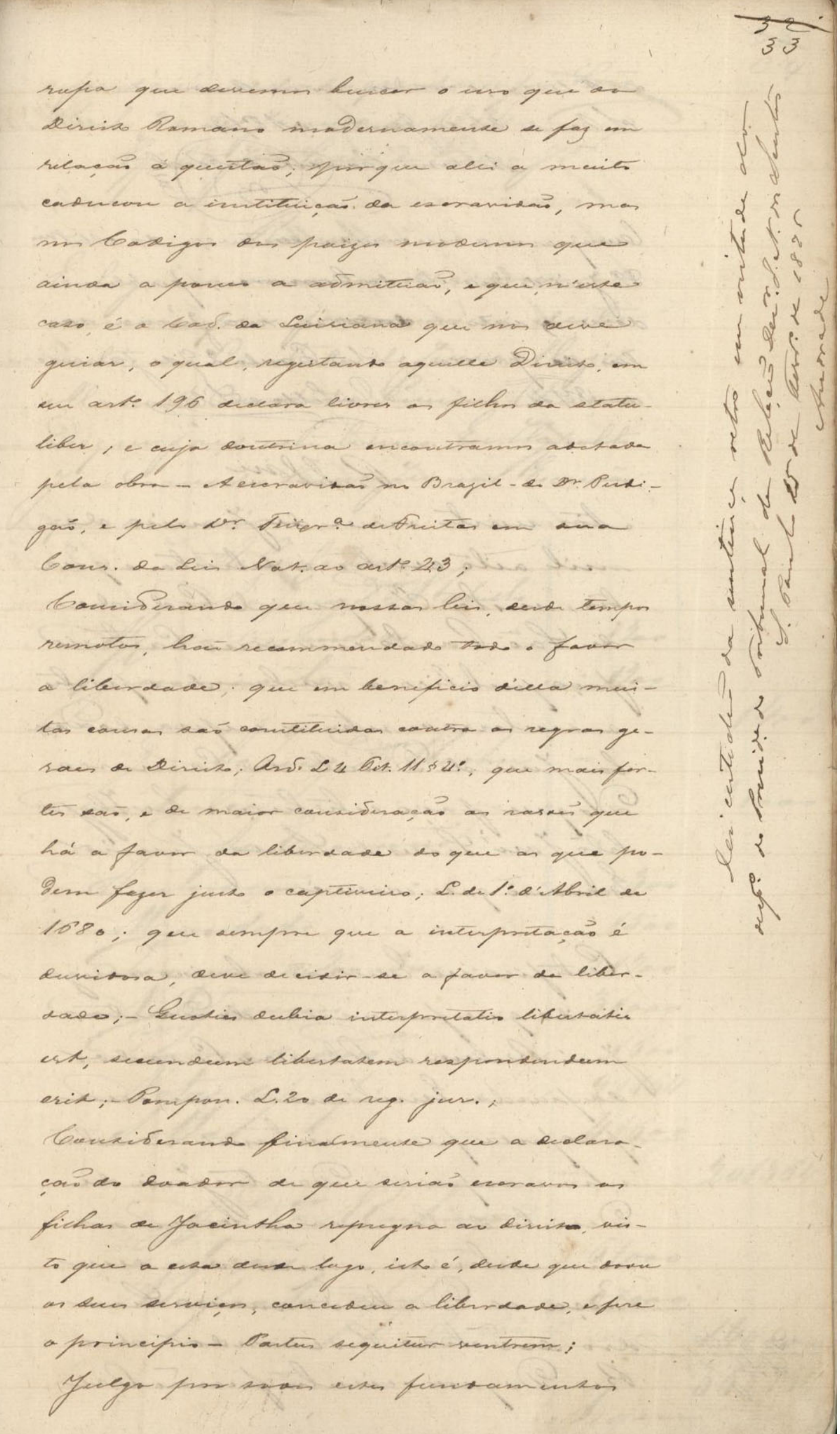


Fólio 33R ${ }^{9}$

ropa que devemos buscar o uso que do Direito Romano modernamente se faz em relaçaõ a questaõ; porque alei á muito caducou a instituiçaõ da escravidaõ, mas 5 nos Codigos dos paizes modernos que ainda a pouco a admitiaõ, e que n'esse caso é o Codigo da Luisiana que nos deve guiar, o qual, registando aquelle Direito, em seu artigo 196 declara livres os filhos da statuliber, e cuja doutrina encontramos adotada pela obra - A escravidaõ no Brazil - do Doutor Perdigaõ, e pelo Doutor (Teixeira) de Freitas em sua Consolidação da Leis (Nat) ao artigo 23; Considerando que nossas leis, desde tempos remotos, haõ recommendado todo o favor a liberdade; que em beneficio d'ella muitas causas saõ constituidas contra as regras geraes de Direito; Arestos Lei 4 Titulo $11 \S 4^{0}$, que mais fortes saõ, e de maior consideraçaõ as rasoẽs que há a favor da liberdade do que as que podem fazer justo o captiveiro; Lei de $1^{\underline{0}}$ d'Abril de 1680; que sempre que a interpretaçaõ é duvidosa, deve decidir-se a favor da liberdade; - Ladies dubia interpretatio libertaes est, secundum libertatem respondendum eris; - (ilegível) Lei 20 de regimento juridico; Considerando finalmente que a declaracaõ do doador de que seriaõ escravas as filhas de Jacintha repugna ao direito, visto que a essa dever logo, isto é, desde que doou os seus serviços, concedeu a liberdade, e fere o principio - Partus sequitur suntrem; Julgo por bons estes fundamentos

\footnotetext{
${ }^{9}$ Este fólio possui uma observação na lateral na transversal, anotada por terceiro, que não foi editada.
} 
a Iliase, e candenino ar A. nus eutas.

E. Bonc 26 der fanis. or $80 / 4$

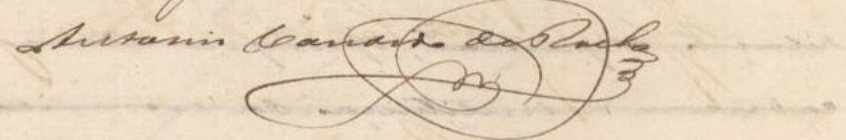

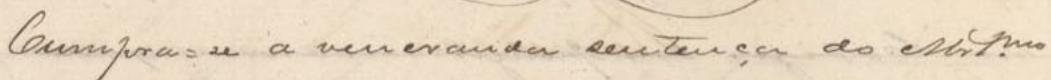
D. Juis de Diguto da bomaren, pu blecur-

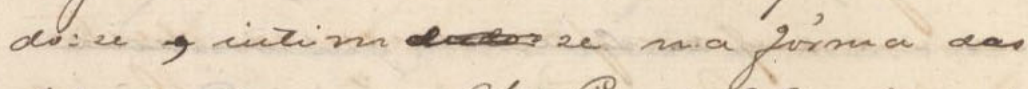

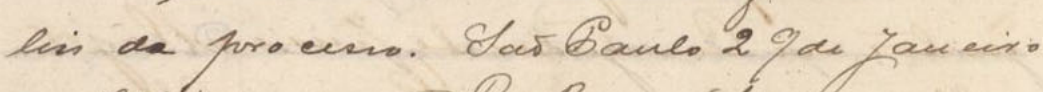

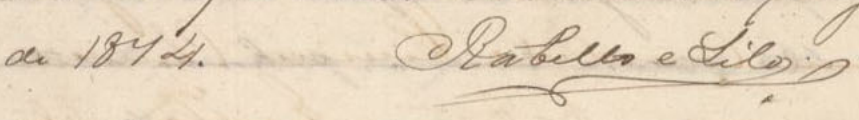

$$
\text { Selupere }
$$

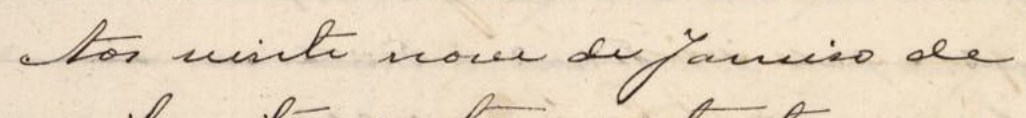
wil acto euvbs e whula e gua

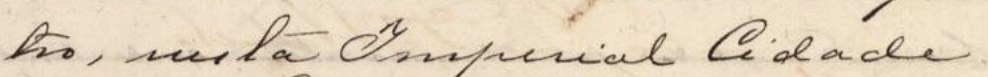

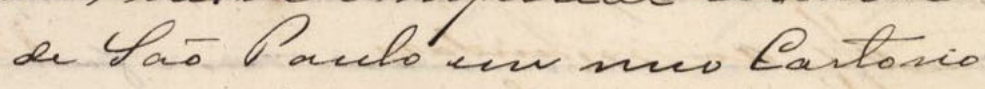

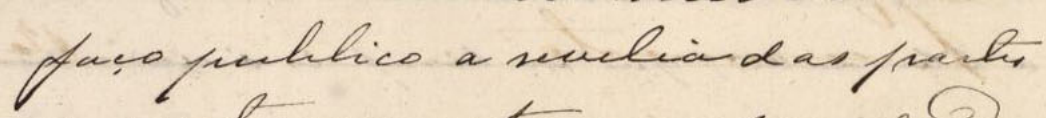

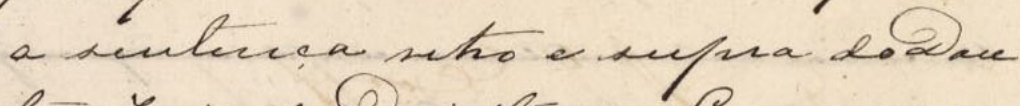
low Yuir sle 2uilo da Corrusca

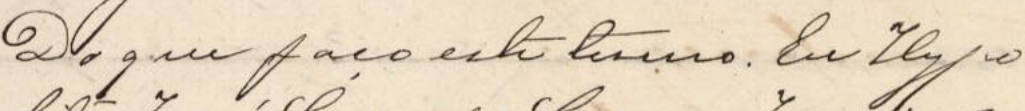

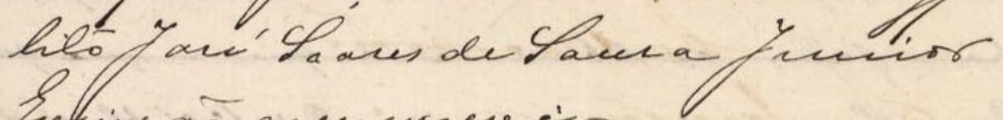

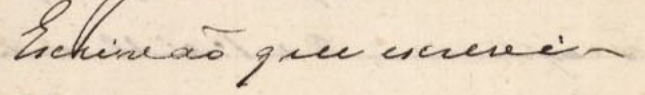

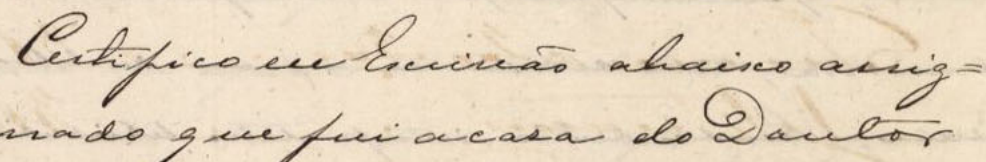

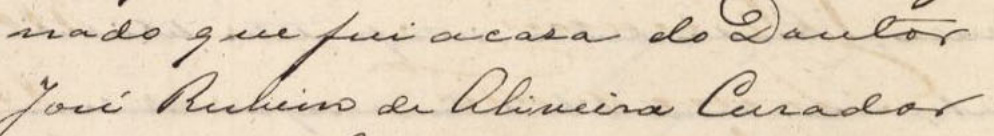

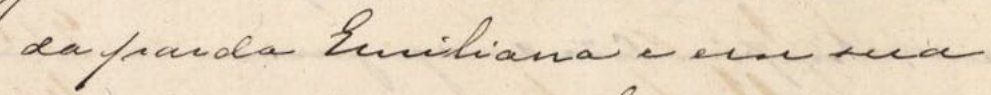

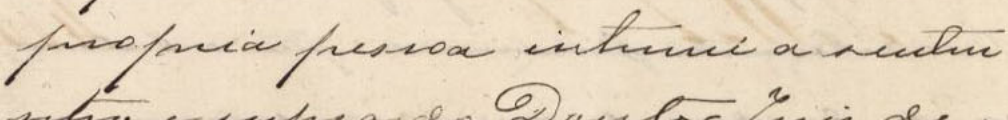
who expera do Waculor zuci de

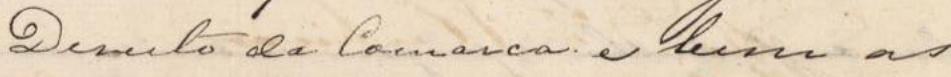

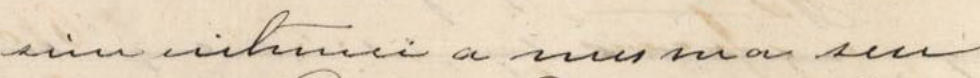

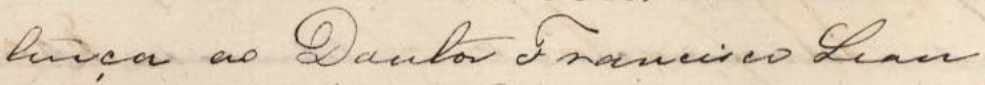

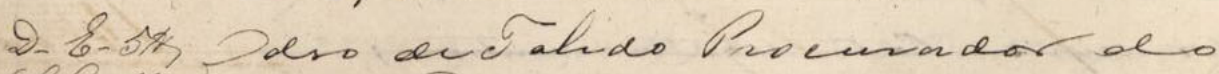

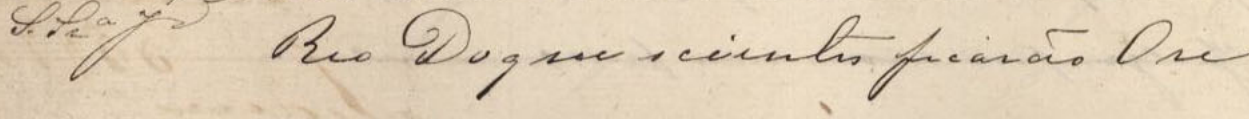


Fólio 33V

a Autora livre, e condenno ao Réu nas custas.

São Paulo 29 de janeiro de 1874

Antonio Candido da Rocha ${ }^{10}$.

${ }^{10}$ Este fólio possui a seguir anotações de terceiro, que não foram editadas 


\subsection{DOC 4}

Documento: Acórdão (Relatório e Decisão)

Remetentes: juízes desembargadores representando a Justiça Estadual de São Paulo Tribunal da Relação - $2^{\mathrm{O}}$ grau

Local: São Paulo

Processo: 03/1873

Data: 17 de março de 1874

Desembargador Relator: Olegário Herculano de Aquino e Castro (responsável pelo Relatório)

Destinatários:

Apelante: Antonio Teixeira de Carvalho

Apelada: Emiliana Parda

Descrição: 4 fólios- páginas 50 verso, 51 recto e verso, 52 recto, sendo o relatório de um só punho, os votos pelos punhos dos respectivos desembargadores responsáveis, e a decisão pelo punho do desembargador presidente, Dr Alencar Araripe. Trata-se de uma ação de liberdade intentada por uma escrava, que nascera de ventre-livre, porém encontrava-se na condição de escrava. Fundamenta seu pedido em documento de doação feito pela ex-senhora. Sentença que julga procedente o pedido da autora, confirmando sua situação de livre, em virtude do nascimento de mãe ex-escrava. O réu apela da decisão, que é confirmada pelo Tribunal da Relação, conforme segue no Relatório e Decisão. 
1.234. Qutatiris

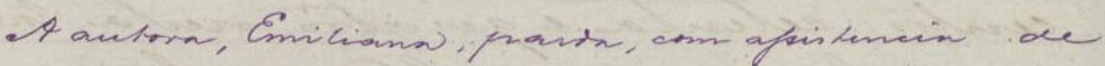

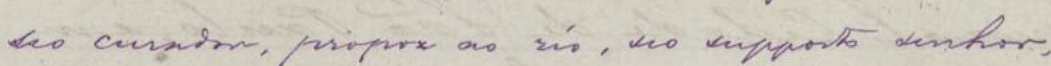

a precente acen mominifunin, no intento be

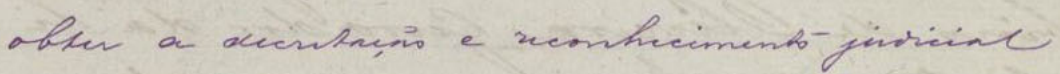

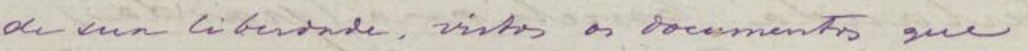
eptibe e as considenacies que spende en keng petricos defle 25.

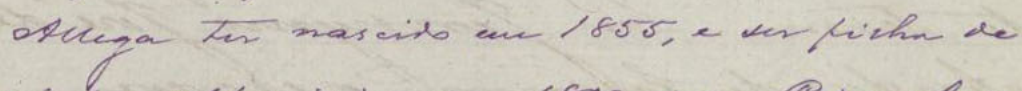

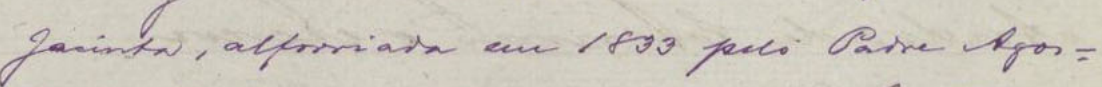

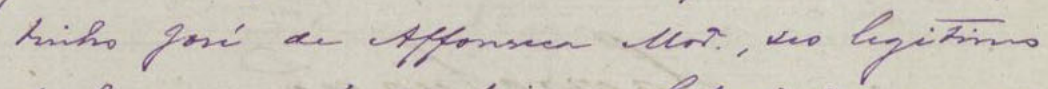

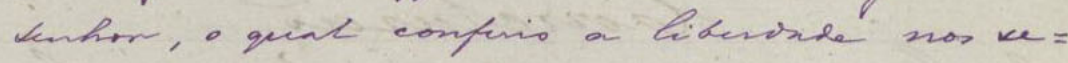
quintes terms, constantes do documento originat a' P26:

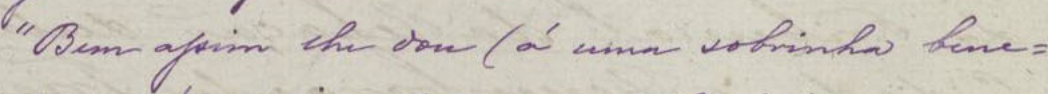

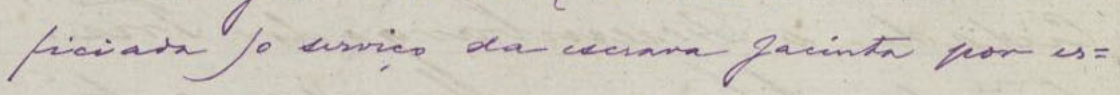
frace de 23 amms; e me mb timpo tives elguns

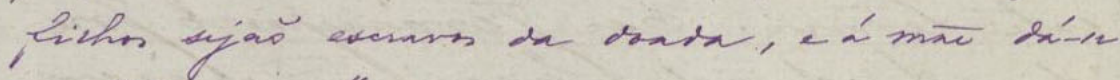
a kibesade."

Emais fandur.

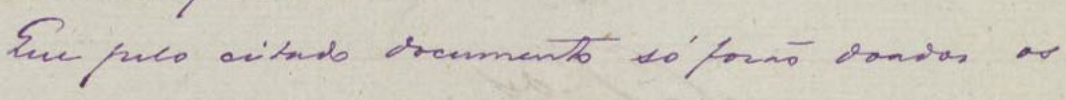
devices de faciurs, e mat a prear desta.

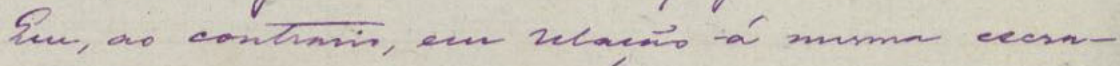

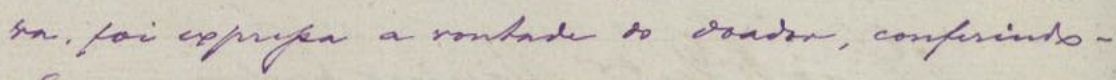
the inmediata - isteina libesdade, nas ga =

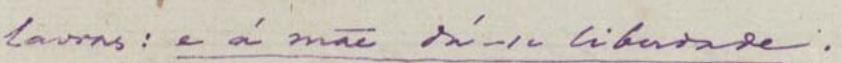

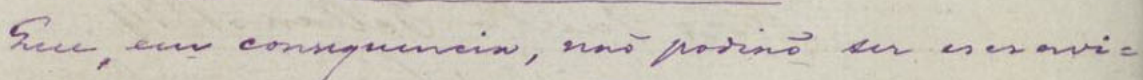

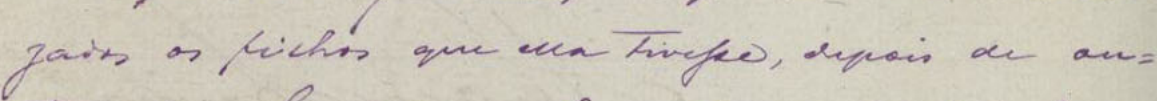

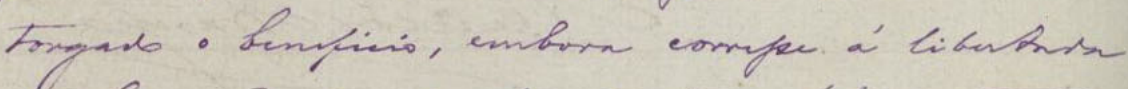

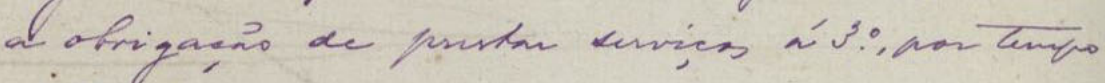
ditesminaro. 
Fólio 50V

\section{Número 234 Relatorio}

A autora, Emiliana, parda, com assistencia de seo curador, propoe ao réo, seo supposto senhor, a presente acção mannumissoria, no intento de

5 obter a decretaçaõ e reconhecimento judicial de sua liberdade, vistos os documentos que exhibe e as consideraçoẽs que expende em suas petiçoẽs de folhas 3 e 25 .

Allega ter nascido em 1855, e ser filha de Jacinta, alforriada em 1833 pelo Padre Agostinho José de Affonseca Moreira, seo legitimo senhor, o qual conferio a liberdade nos se $=$ guintes termos, constantes do documento em original á folhas 26 :

"Bem assim lhe dou (á uma sobrinha bene= ficiada) o serviço da escrava Jacinta por es= paço de 23 annos; e se neste tempo tiver alguns filhos sejaõ escravos da doada, e á maẽ dá-se a liberdade." E mais pondera:

Que pelo citado documento só foraõ doados os serviços de Jacinta, e não a pessoa desta.

Em, ao contrario, em relaçaõ á mesma escrava, foi expressa a vontade do doador, conferindolhe immediata a inteira liberdade, nas pa= lavras: e á maẽ dá-se liberdade. Que, em consequencia, naõ podião ser escravi= zados os filhos que ella tivesse, depois de ou= torgado o beneficio, embora coubesse à libertada a obrigaçaõ de prestar serviços à terceiro, por tempo determinado. 


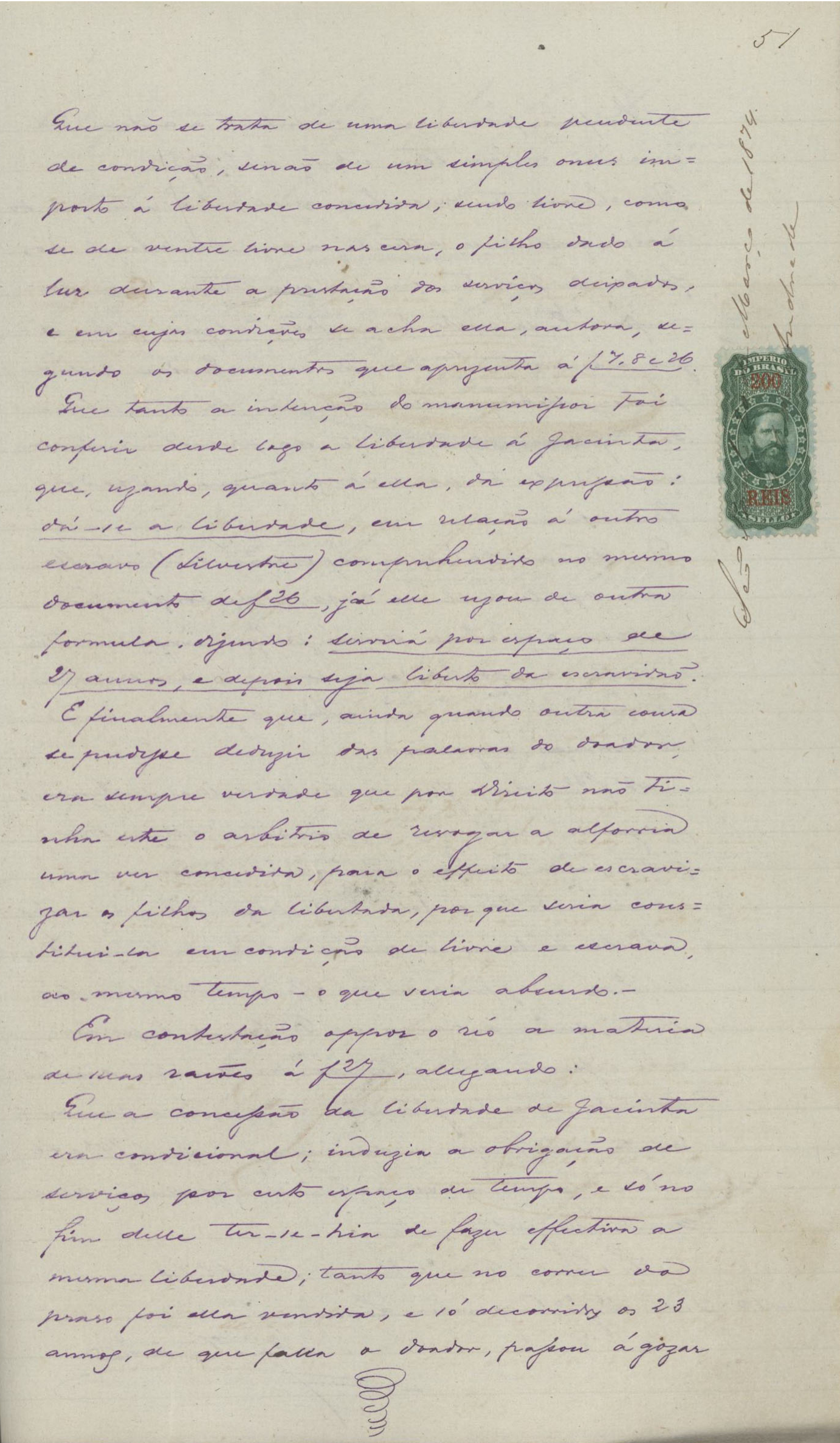


Fólio 51R ${ }^{11}$

Que naõ se trata de uma liberdade pendente de condiçaõ, senaõ de um simples onus im= posto à liberdade concebida, sendo livre, como se de ventre livre nascera, o filho dado à

5 luz durante a prestaçaõ dos serviços deixados, e em cujas condiçoẽs se acha ella, autora, se $=$ gundo os documentos que aprezenta à folhas7, 8 e 26.

Que tanto a intençaõ do manumissor foi conferir desde logo a liberdade á Jacinta, que, uzando, quanto a ella, da extinssaõ:

dá-se a liberdade, em relaçaõ á outro escravo (Silvestre) comprehendido no mesmo documento defolhas26, já elle uzou de outra formula, dizendo: servirá por espaço de 27 annos, e depois seja liberto da escravidaõ. E finalmente que, ainda quando outra cousa se pudesse deduzir das palavras do doador, era sempre verdade que por Direito naõ ti $=$ nha este o arbitrio de revogar a alforria uma ves concedida, para o effeito de escravi= zar os filhos da libertada, porque seria cons= titui-la em condiçaõ de livre e escrava, ao mesmo tempo - o que seria absurdo -

Em contestaçaõ appos o réo a materia 25 de suas rasoẽs á folhas 27 , allegando:

Que a concessaõ da liberdade de Jacinta era condicional; induzia a obrigaçaõ de serviços por certo espaço de tempo, e só no fim dele ter-se-hia de fazer effectiva a 30 mesma liberdade; tanto que no correr do praso foi ella vendida, e só decorridos os 23 annos, de que falla o doador, passou á gozar

${ }^{11}$ Este fólio possui um selo e uma observação na lateral na transversal, anotada por terceiro. 
do binficio, furmaniecends no entants a autora na eseravisis en que lem estarb ale' injo.

Eve claramente se conhuce qual fai a intencios do donsor, quands se attende a'que, en nlavio as fichs de javinta, dir ece we tims bem sp = prifoor: "E ve muthe hempo tiver alguns fichs ce =

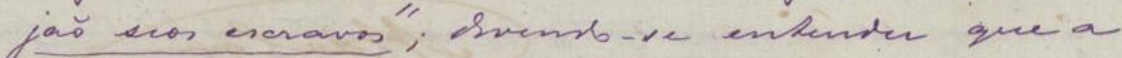
whince mberquente: "L $a$ mat da'-re a biberdade" ficana dependente do preenchimento da condicas de tempe e vesice a'que davor far seferencin.

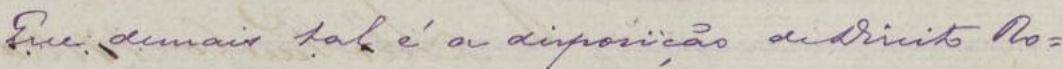
man applicavel a caso, e deveruformida =

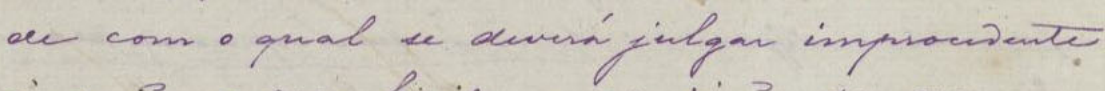

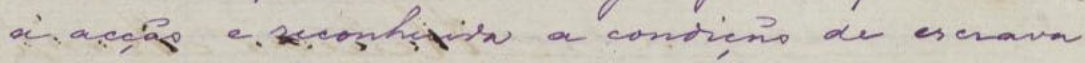
enque alié agon ten estases a actorn. ven contisticino alguna. ot'f32 deo: Guir de rivits a ven sententer,

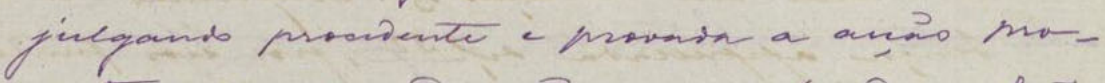

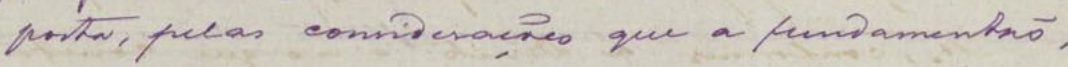
e declasands a autora himo, pagas peco zio a cuntry.

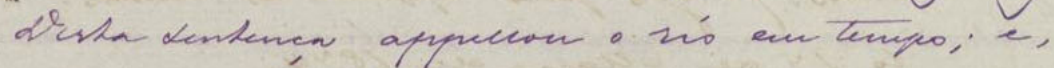

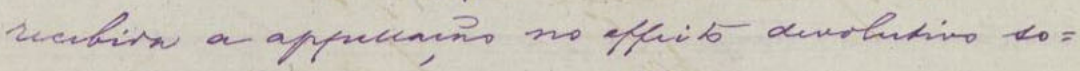

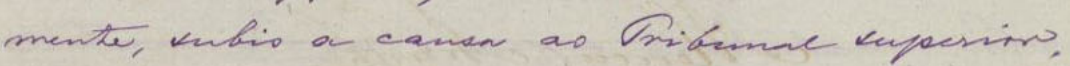
ond rifens as fraster de vo divit, deensolvenss mas layganicith ous zacalo e fumin-

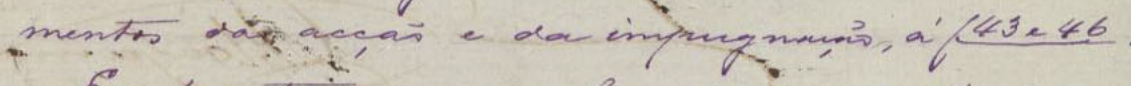

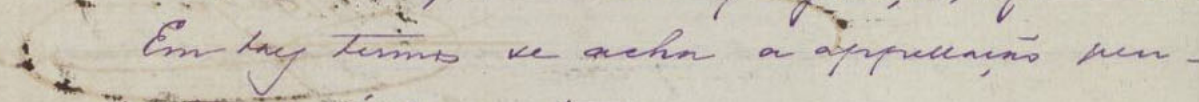
äcilkze de fingaments.

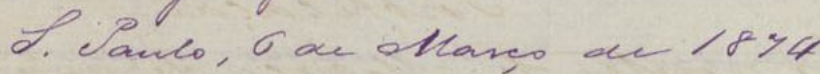

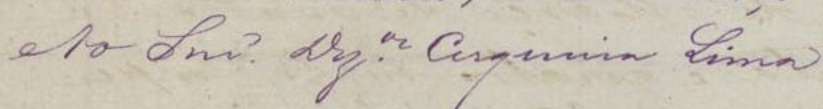

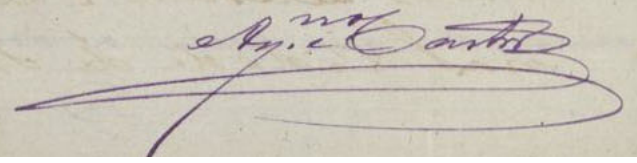


Fólio 51V

do beneficio, permanecendo no entanto a autora na escravidaõ em que tem estado até hoje.

Que claramente se conhece qual foi a intençaõ do doador, quando se attende á que, em relaçaõ aos

5 filhos de Jacinta, dis elle em termos bem ex= pressos: "E se neste tempo tiver alguns filhos se= jaõ seos escravos"; devendo-se entender que a phrase subsequente: "e á maẽ dá-se a liberdade" ficava dependente do preenchimento da condiçaõ de tempo e serviço á que o doador fas referencia.

Que demais tal é a disposiçaõ de Direito Ro= mano applicavel ao caso, e de conformida= de com o qual se deverá julgar improcedente a acçaõ e reconhecida a condiçaõ de escrava em que até agora tem estado a autora, sem contestaçaõ alguma.

Á folhas 32 deo o Juiz de direito a sua sentença, julgando procedente e provada a acçaõ proposta, pelas consideraçoẽs que a fundamentaõ, e declarando a autora livre, pagas pelo réo as custas. Desta sentença appellou o réo em tempo; e, recebida a appellaçaõ no effeito devolutivo so= mente, subio a causa ao Tribunal Superior, onde disseraõ as partes de seo direito, desenvolvendo mais largamente as rasoẽs e funda $=$ mentos da acçaõ e da impugnaçaõ, á folhas 43 e 46.

Em taes termos se acha a appellaçaõ pendente de julgamento.

30 São Paulo, 6 de Março de 1874

Ao Senhor Dezembargador Cerqueira Lima

Aquino e Castro. 


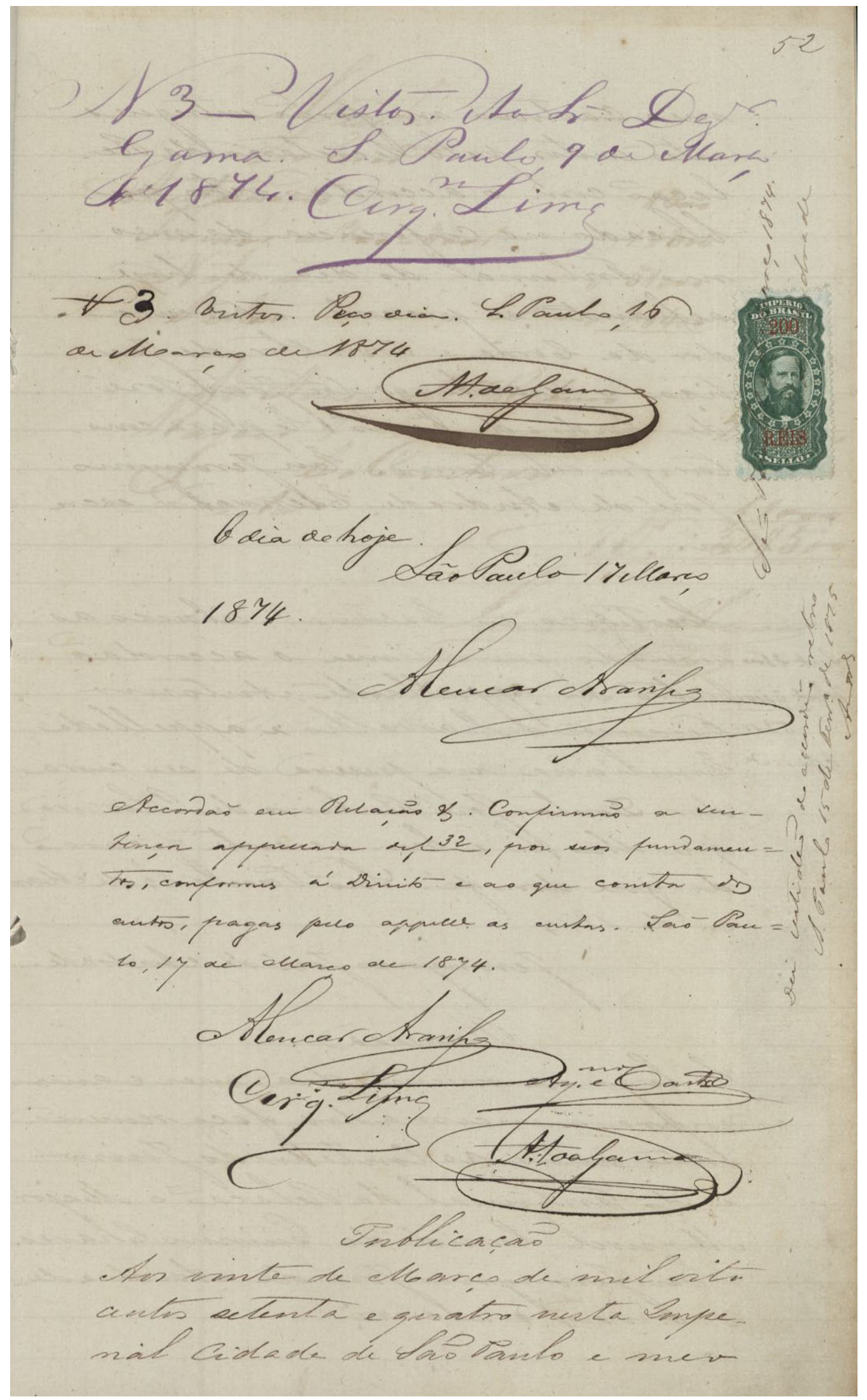


Fólio $52 \mathrm{R}^{12}$

Número 3 - Vistos. Ao Senhor Dezembargador

Gama. Saõ Paulo, 9 de Março

de 1874. Cerqueira Lima ${ }^{13}$

5 Accordaõ em Relaçaõ. Confirmaõ a sen-

tença appellada defolhas 32 , por seos fundamen=

tos, conformes á Direito e ao que consta dos

autos, pagas pelo appellante as custas. Saõ $\mathrm{Pau}=$

lo, 17 de Março de 1874.

10 Alencar Araripe

Aquino e Castro

Cerqueira Lima

Agostinho Luiz da Gama ${ }^{14}$

12 Este fólio possui na lateral transversal anotações de terceiro, que não foram editadas

13 Este fólio possui, a seguir, anotações de terceiro, que não foram editadas

14 Este fólio possui, a seguir, anotações de terceiro, que não foram editadas 


\subsection{DOC 5}

Documento: Sentença

Remetente: juiz ordinário a representando Justiça Estadual de São Paulo - $1^{\mathrm{O}}$ grau

Local: Bragança

Processo: 52/1873

Juiz: Joaquim Roberto de Carvalho Pinto

Destinatários:

Autor: José

Réu: Luis Antonio Lopes da Silva

Data da sentença: 18 de Novembro de 1873

Descrição: 4 fólios- páginas 41 recto e verso, 42 recto e verso, anotados por apenas um punho, o próprio juiz de direito proferidor da decisão. Trata-se de uma ação de liberdade intentada por um escravo, fundamentando seu pedido na lei de proibição do tráfico de escravos. Sentença que julga improcedente o pedido do autor, considerando ausência de provas que comprovassem ser ele vítima de tráfico ilegal de escravos. 


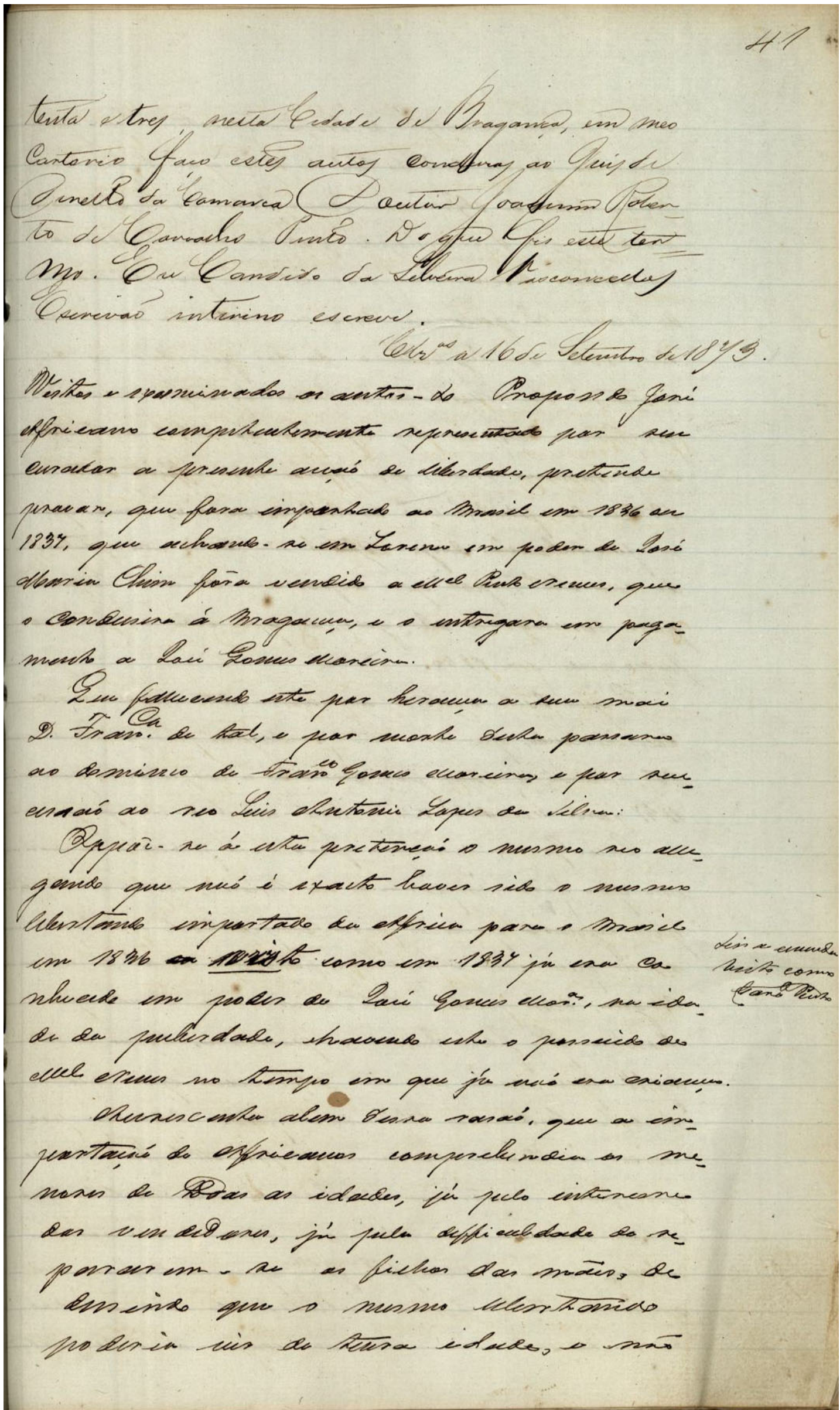


Fólio 41R

Vistos e examinados os autos - (ilegível) Propondo José

Africano competentemente representado por seu curador a presente acçaõ de liberdade, pretende provar, que fora importado ao Brasil em $1836 \mathrm{ou}$

5 1837, que achando-se em Lorena em poder de José Maria (Oliveira) fôra vendido ao Coronel Pinto Nunes, que o conduzira á Bragança, e o entregara em pagamento a Raú Gomes Moreira.

Que favorecendo este por herança a sua mai

Dona Francisca de tal, e por morte d'esta passara ao dominio de Francisco Gomes Moreira, e por successaõ ao reo Luis Antonio Lopes da Silva: Oppoẽ-se á esta pretençaõ o mesmo reo allegando que naõ é exacto haver sido o mesmo libertando importado da Africa para o Brasil em 1836 [visto] como em 1837 já era co- ${ }^{15}$ nhecido em poder de Raú Gomes Moreira, na idade da puberdade, havendo este o possuido de Coronel Nunes no tempo em que já naõ era criança. Acrescenta alem dessa rasaõ, que a importacaõ do africanos comprehendia os menores de (todas) as idades, já pelo interresse dos vendedores, já pela dificuldade de repassarem-se os filhos das maẽs, de25 (ilegível) que o mesmo libertando poderia vir de (tenra) idade, e não

${ }^{15}$ Ao lado: Leia a emenda visto como assinatura do Juiz. 


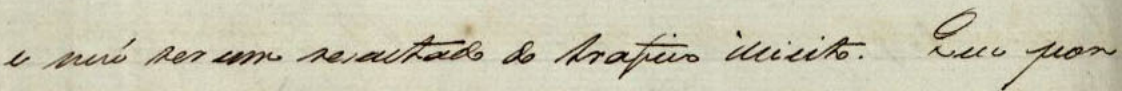

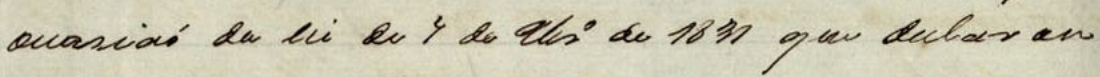

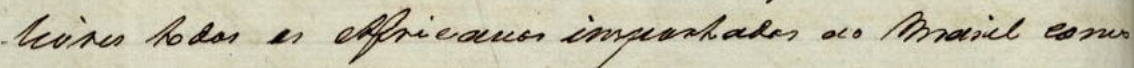

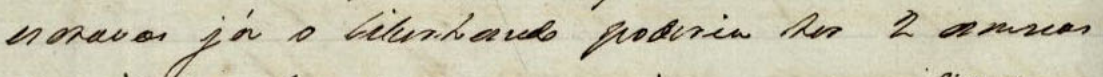

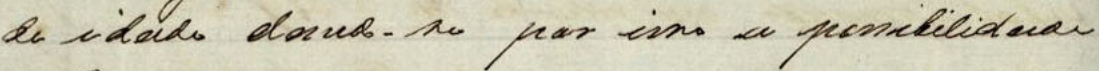

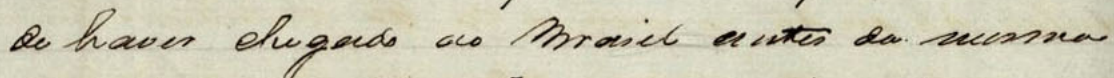

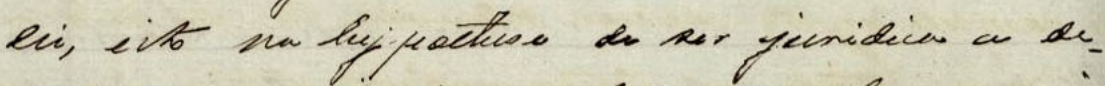

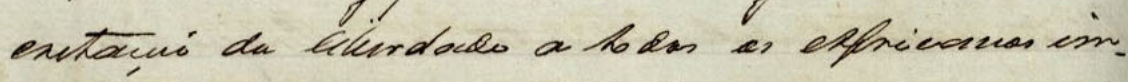

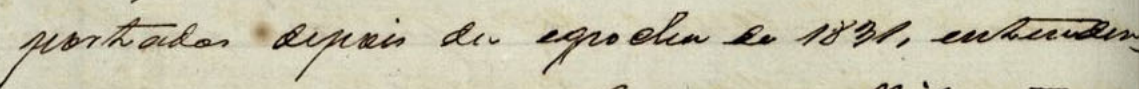

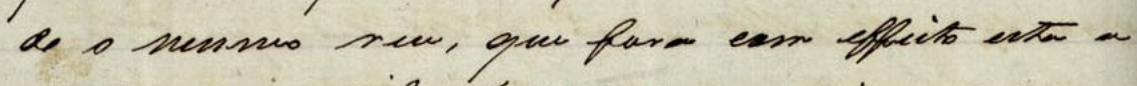

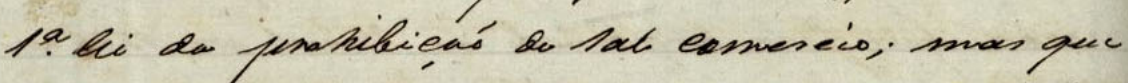

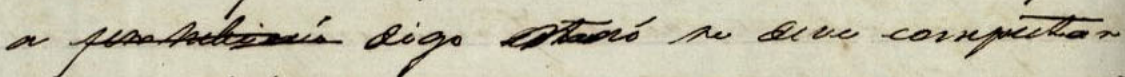

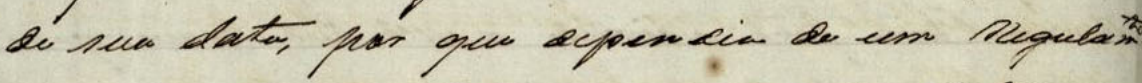

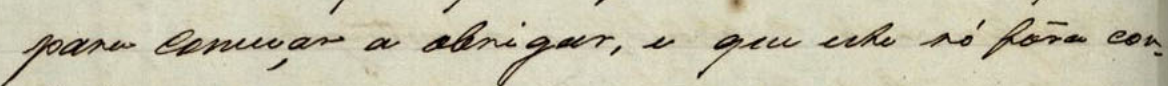
Acissuced un p8iso.

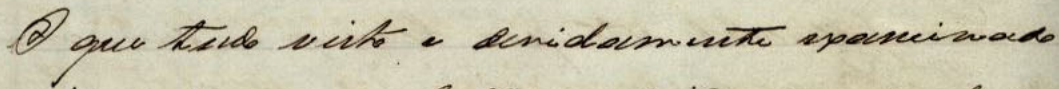

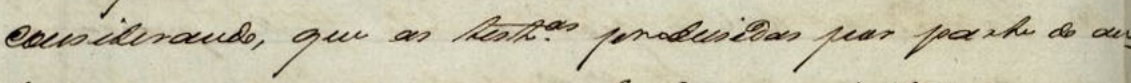

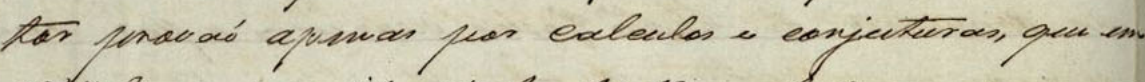

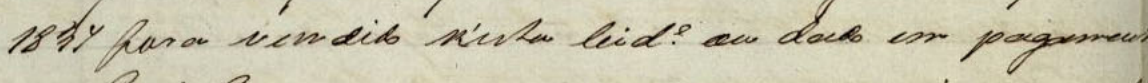

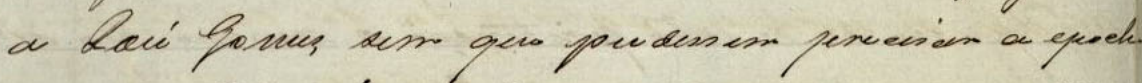

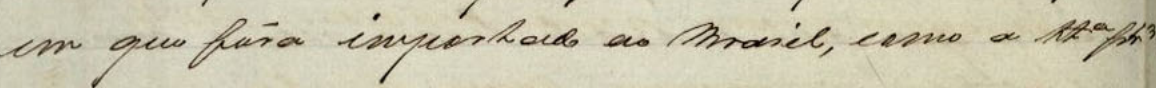

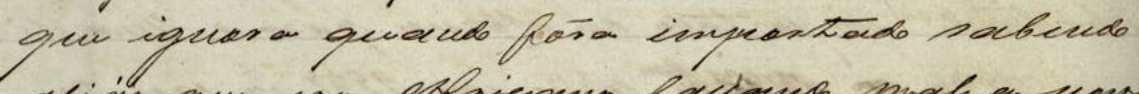

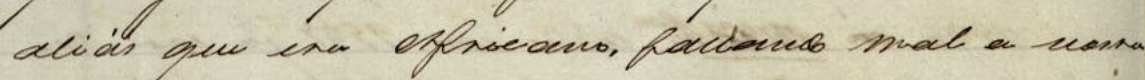

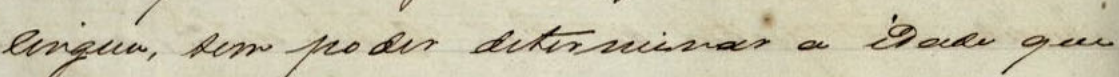

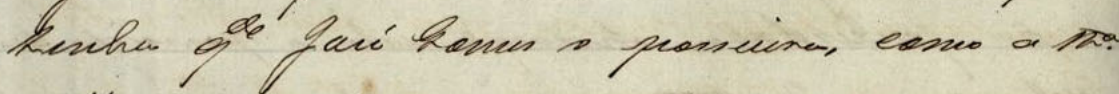

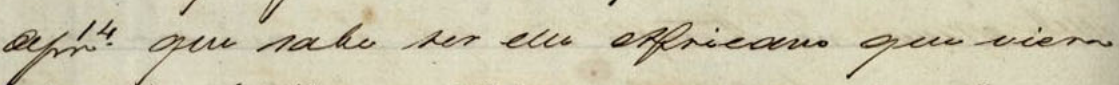

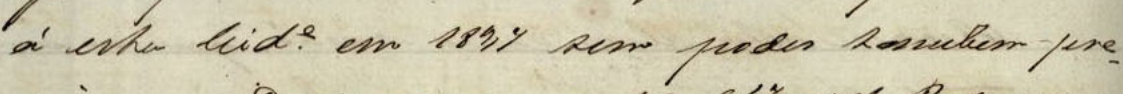

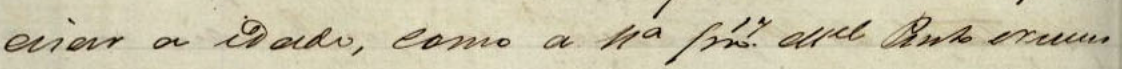

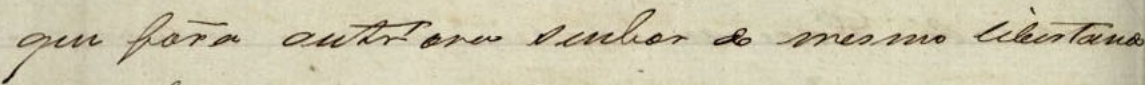

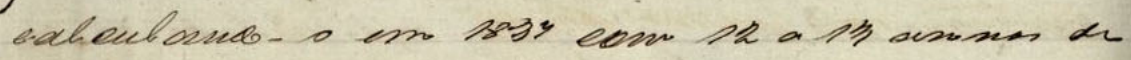

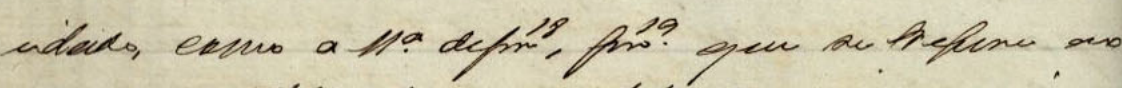

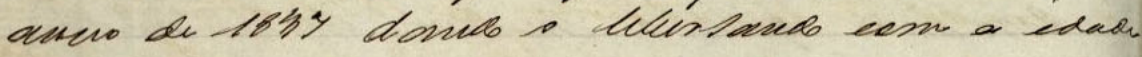

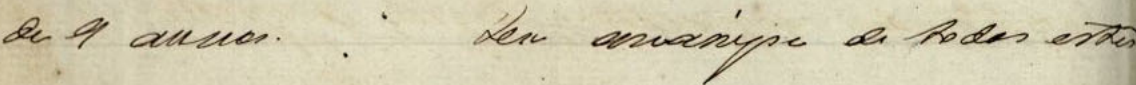


Fólio 41V

e naõ ser um resultado de tráfico illicito. Que por ocasiaõ da lei de 7 de Novembro de 1831 que declarou livres todos os Africanos importados ao Brasil como escravos já o libertando poderia ter 2 annos

5 de idade dando-se por isso a possibilidade de haver chegado ao Brasil antes da mesma lei, isto na hiypohtese de ser juridica a decretação da liberdade a todos os Africanos importados depois da epocha de 1831, entendendo o mesmo reu, que fora com effeito esta a $1^{\text {a }}$ lei da prohibiçaõ de tal comercio; mas que a (rasurado) digo (rasurado) se deve computar de sua data, por que dependia de um regulamento para começar a obrigar, e que este só fõra confecionado em 1850.

$\mathrm{O}$ que tudo visto e devidamente examinado considerando, que as testemunhas produzidas por parte do autor provaõ apenas por calculos e conjecturas, que em 1837 fora vendido n'esta Cidade ou dado em pagamento de Raú Gomes sem que pudessem precisar a epocha em que fóra importado ao Brasil, como a testemunha folhas 34 que ignora quando fóra importado sabendo aliás que era Africano, falando mal a nossa lingua, sem poder determinar a idade que tinha quando Raú Gomes o possuira, como a testemunha defolhas 14 que sabe ser elle Africano que viera á esta Cidade em 1837 sem poder tambem precisar a idade, como a testemunha folhas 17 Coronel Pinto Nunes que fõra outróra senhor do mesmo libertando calculando-o em 1837 com 12 a 13 annos de idade, como a testemunha defolhas 18 , folhas 19 que se refere ao anno de 1837 dando o libertando com a idade de 9 annos. Por (análise) de todos estes 


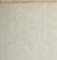

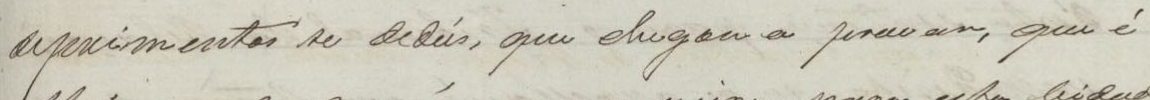

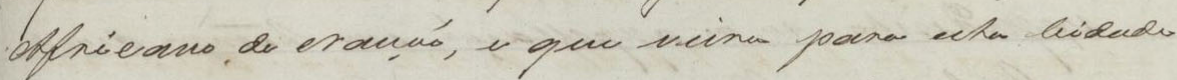

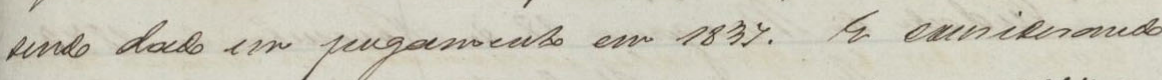

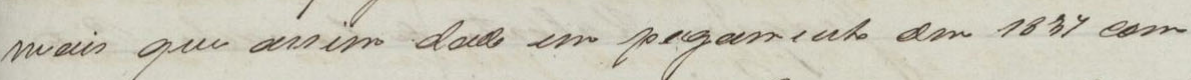

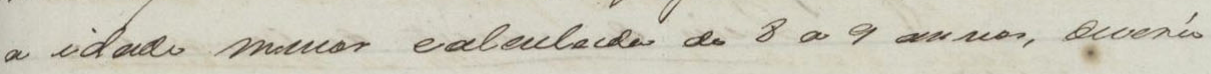

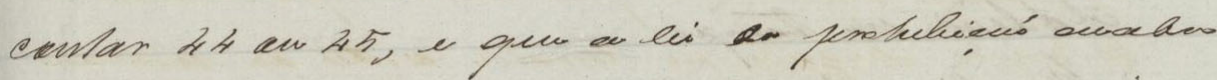

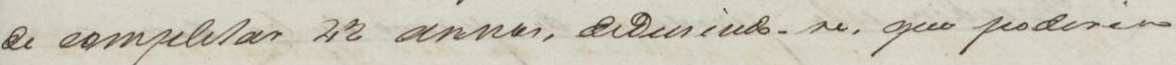

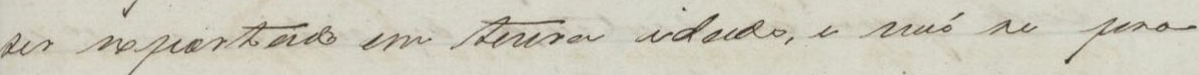

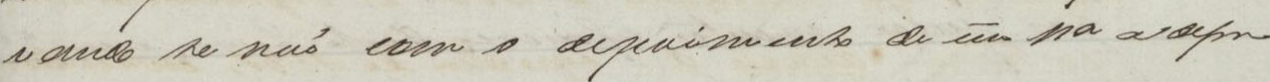

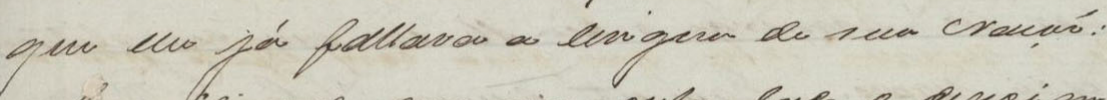

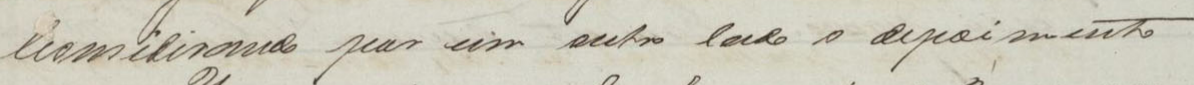

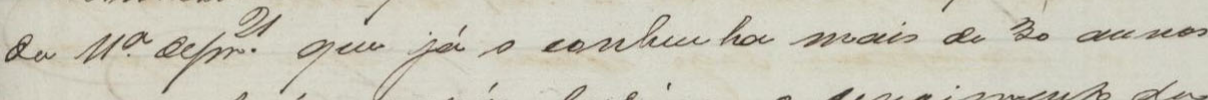
sunde unhaí - rapós lockins, o depecismento der

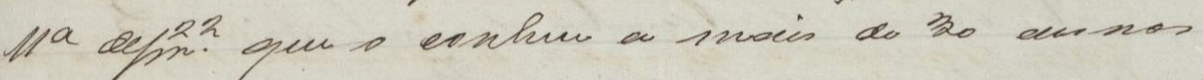

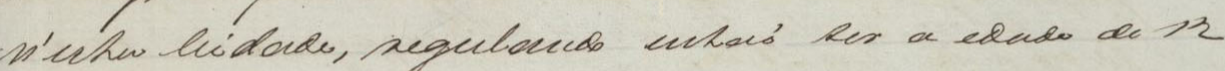

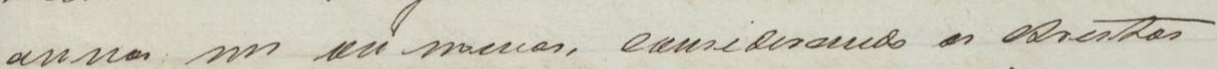

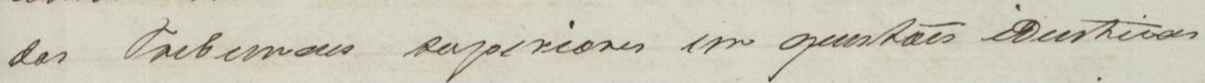
in as operaes ne texn spigide peraod en plieitas,

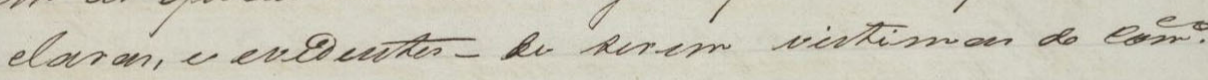

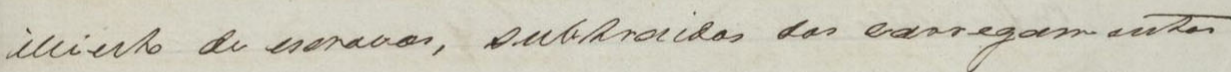

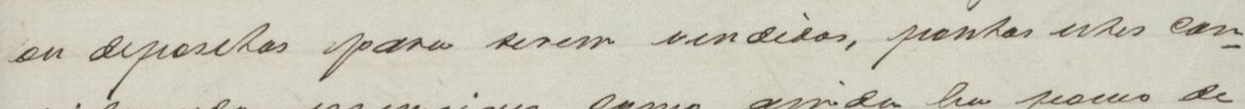

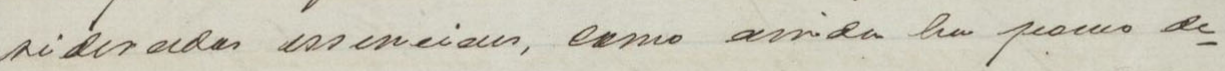

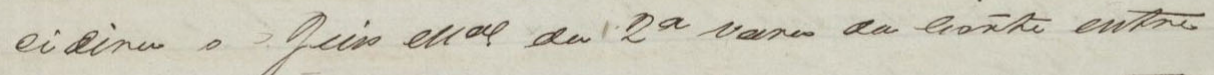

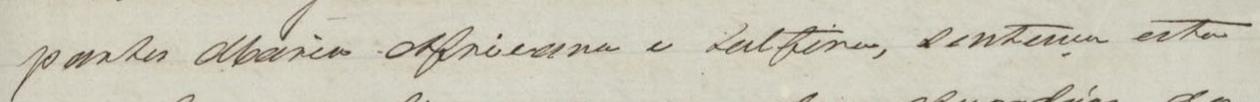

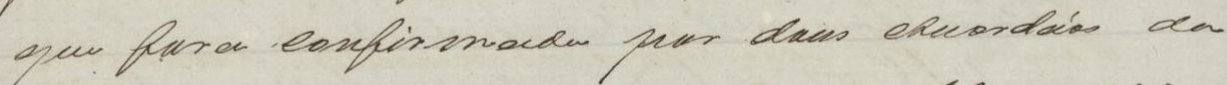

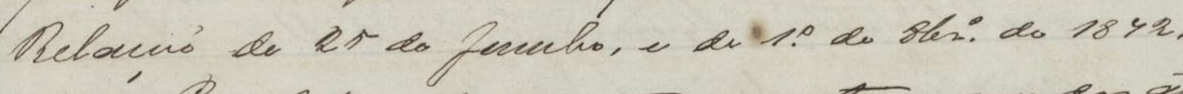

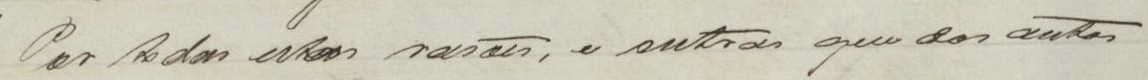

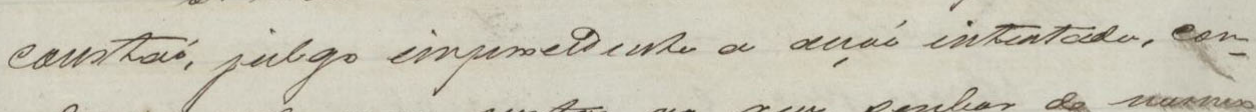

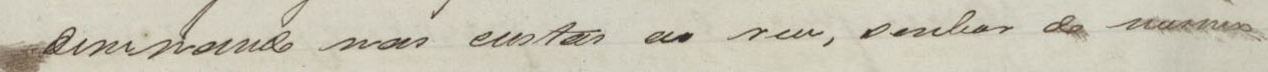
nuthory nw formen des livi.

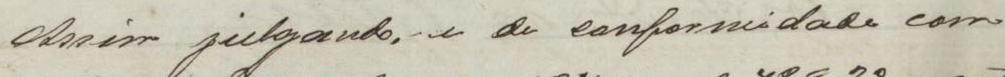

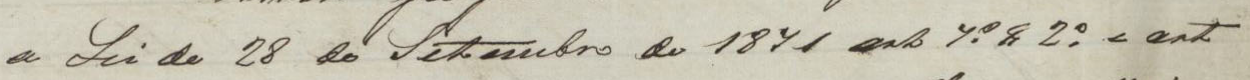

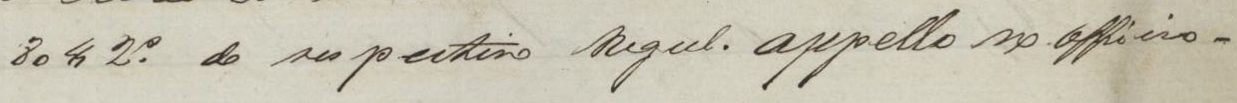


Fólio 42R

depoimentos se dedús, que chegou a provar, que é Africano de Naçaõ, e que viera para esta Cidade sendo dado em pagamento em 1837. E considerando mais que assim dado em pagamento em $1837 \mathrm{com}$

5 a idade menor calculada de 8 a 9 annos, deverá contar 44 ou 45, e que a lei da prohibiçaõ acaba de completar 42 annos, deduzindo-se, que poderia ser exportado em tenra idade, e não se provando se naõ com o depoimento de uma testemuha defolhas que elle já fallava a lingua de sua Naçaõ.

Conciliando por um outro lado o depoimento da testemunha defolhas 21 que já o conheceu ha mais de 30 annos sendo entaõ - rapás ladino, o depoimento da testemunha defolhas 22 que o conheceu a mais de 30 annos n'esta Cidade, regulando entaõ ter a idade de 13 annos mais ou menos. Considerando os Arestos dos Tribunais Superiores em questoẽs identicas em as quais se tem exigido provas explicitas, claras, e evidentes - de serem vitimas de comercio illicito de escravos, subtraidos dos carregamentos ou depositos para serem vendidos, provas estas consideradas essenciais, como ainda ha pouco decidira o Juiz Marechal da $2^{\text {a }}$ Vara da Corte entre partes Maria Africana e Lulfina, sentença esta que fora confirmada por dous Accordaõs da Relaçaõ de 25 de Junho, e de $1^{\mathrm{O}}$ de Dezembro de 1872. Por todas estas rasoẽs, e outras que dos autos constaõ, julgo improcedente a acçaõ intentada, condenando nas custas o reu, senhor do mesmo autor, na forma da lei.

Assim, julgando, e de conformidade com a Lei de 28 de Setembro de 1871 artigo $7^{\mathrm{O}} \S 2^{\mathrm{O}}$ e artigo $80 \S 2^{\mathrm{O}}$ do respectivo Regulamento. Appello no officio- 
DOC 5

112

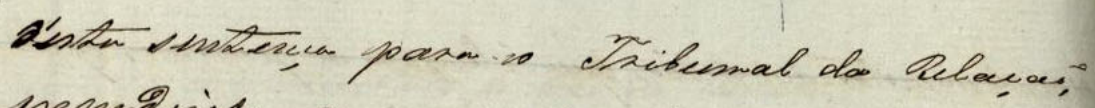

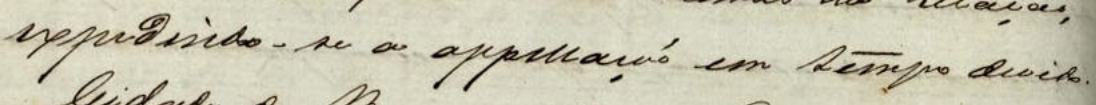
leidade de Mrocganen 18 a Cloveunba de 184\%.

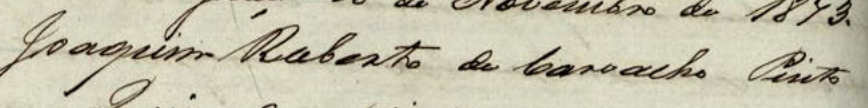
- Quis de acinitit den cemanea.

did deide un thempio

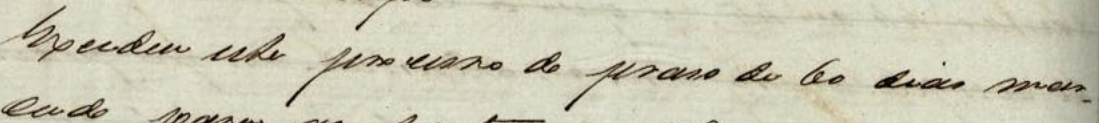

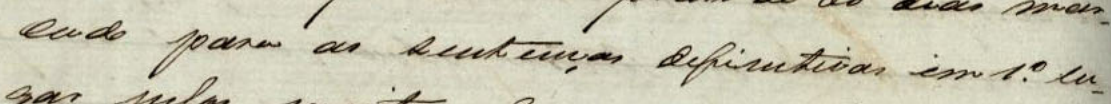

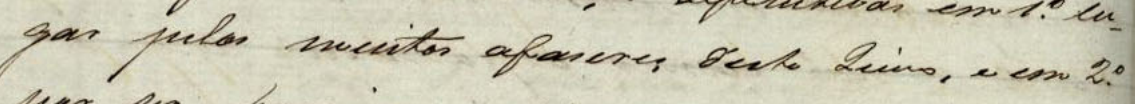

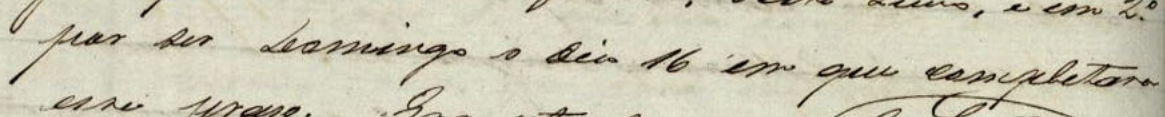

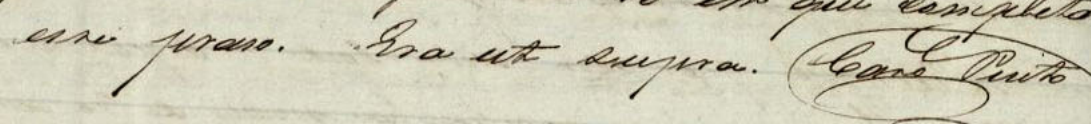

The Cara.

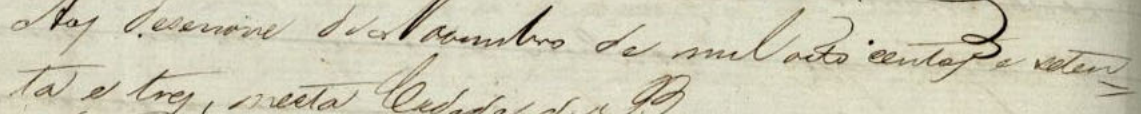

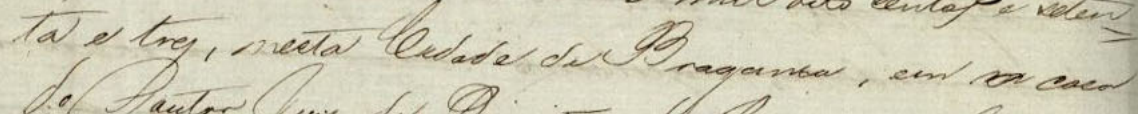

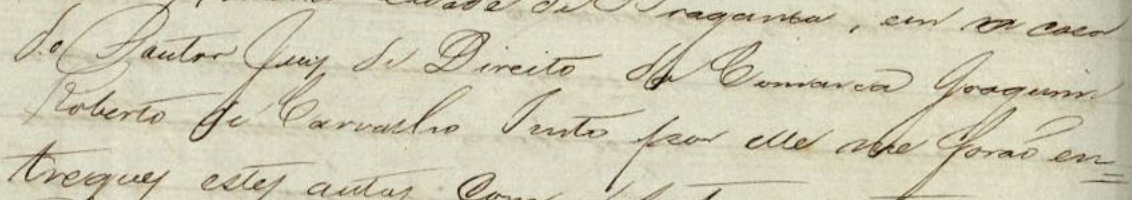

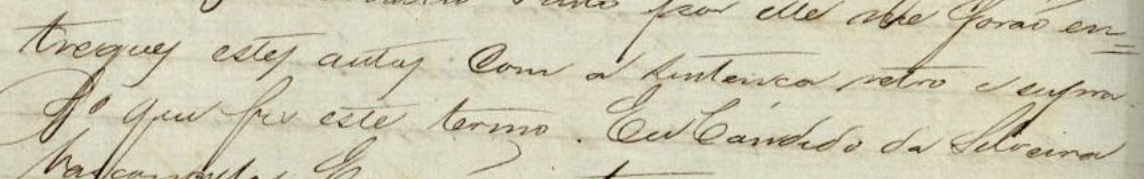

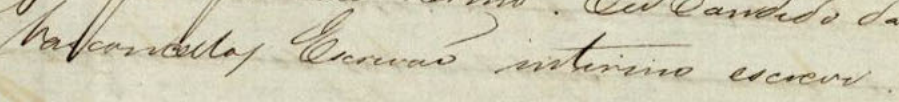

Tha

$$
\text { Candunas. }
$$

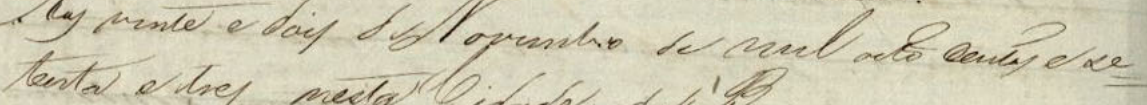

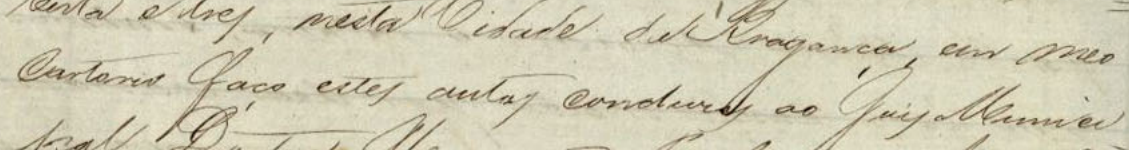

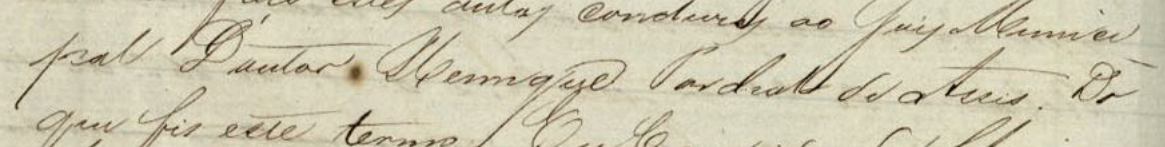

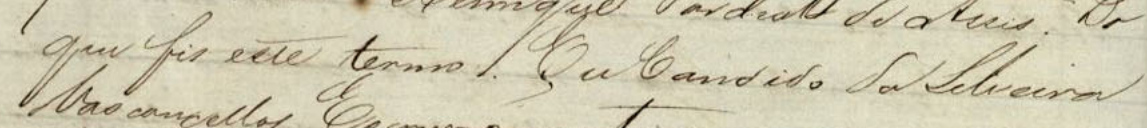

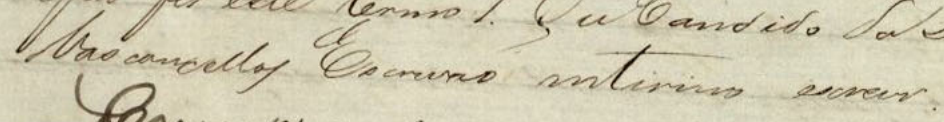

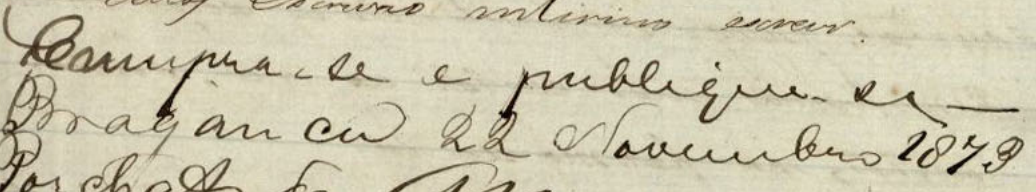
- Porchad de Curs

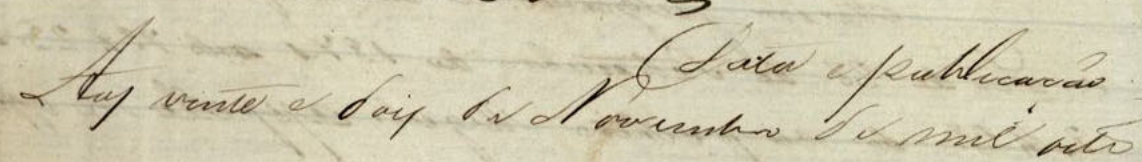


Fólio 42V

d'esta sentença para o Tribunal da Relacaõ, expedindo-se a appellaçaõ em tempo devido.

Cidade de Bragança 18 de Novembro de 1873

Joaquim Roberto de Carvalho Pinto

5 Juiz de Direito da Comarca

Addendo em tempo

Excedeu este processo de praso de 60 dias mar-

cado para as sentenças definitivas em $1^{0} \mathrm{lu}-$

gar pelos muitos afaseres deste Juiso, e em $2^{\mathrm{O}}$

10

por ser domingo o dia 16 em que completara

esse praso.Era ut supra. Joaquim Roberto de Carvalho Pinto ${ }^{16}$

${ }^{16}$ Este fólio possui, a seguir, anotações de terceiro, que não foram editadas 


\section{$4.7 \quad$ DOC 6}

Documento: Acórdão (relatório e decisão)

Remetentes: juízes desembargadores representando a Justiça Estadual de São Paulo Tribunal da Relação - $2^{\mathrm{O}}$ grau

Local: São Paulo

Processo: 52/1873

Destinatários:

Apelante: José (juiz ex-officio)

Apelado: Luis Antonio Lopes da Silva

Data do acórdão: 26 de Novembro de 1874

Desembargador Relator: Ovído Fernando Trigo de Loureiro (responsável pelo Relatório)

Descrição: 8 fólios- páginas 64 recto e verso, 65 recto e verso, 66 recto e verso, 67 recto e 68 recto, sendo o relatório de um só punho, os votos pelos punhos dos respectivos desembargadores responsáveis, e a decisão pelo punho do desembargador Dr Frederico Augusto Xavier de Brito. Trata-se de uma ação de liberdade intentada por um escravo, fundamentando seu pedido na lei de proibição do tráfico de escravos. Sentença que julga improcedente o pedido do autor, considerando ausência de provas que comprovassem ser ele vítima de tráfico ilegal de escravos. O juiz, ex-officio, representando o autor-apelante, recorre da decisão, interpondo recurso de apelação que confirma a sentença, negando novamente a liberdade ao autor-apelante. 
hordede de Sai baulo e meo Rartinis

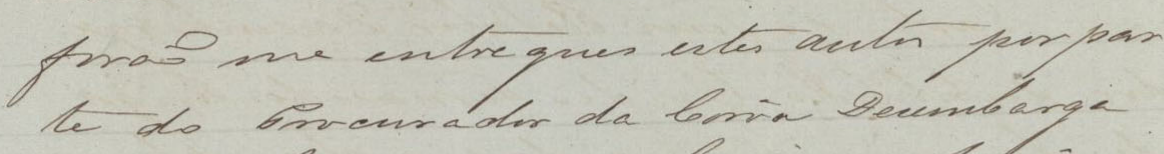

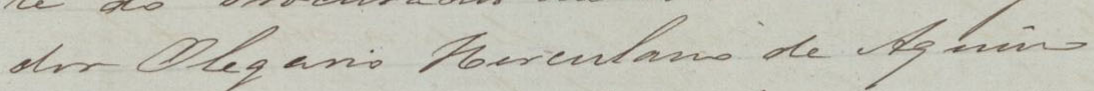
- bactio cun e cole netso, do gurptac

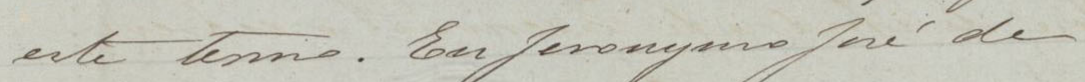

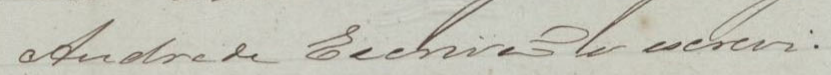

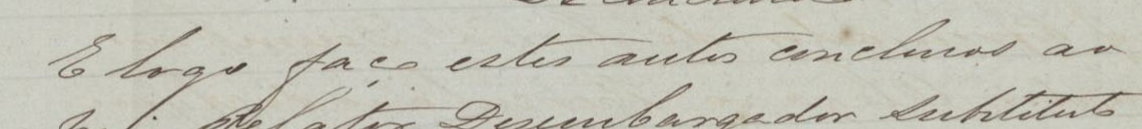

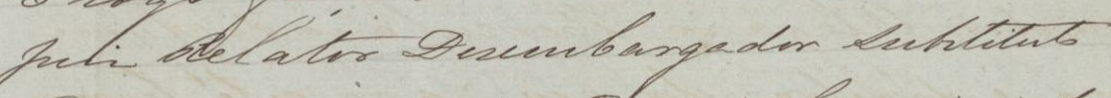

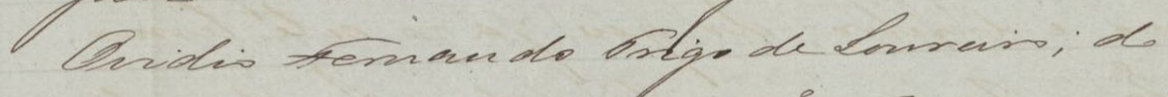

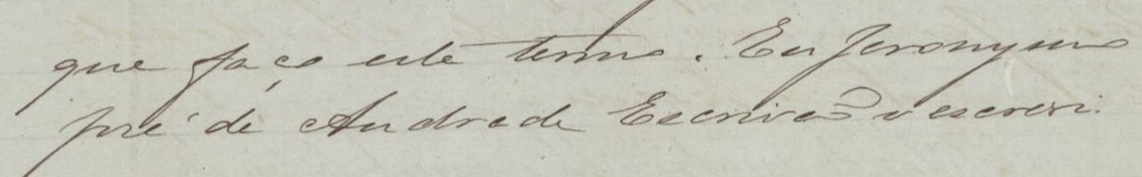<smiles>C=C1C=CC=CC1C</smiles>

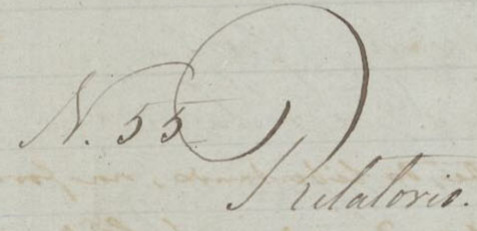

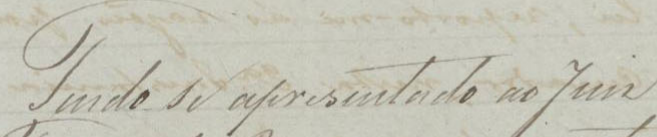

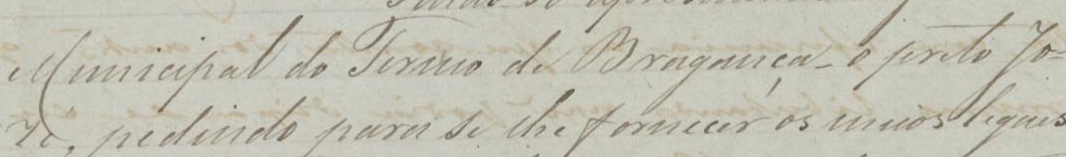

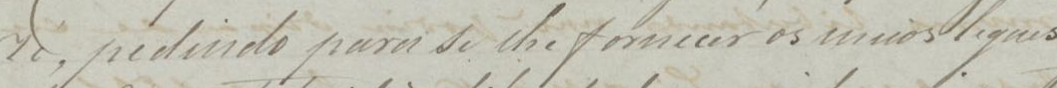

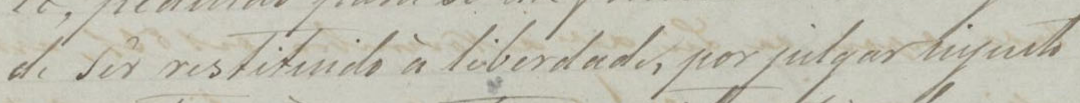

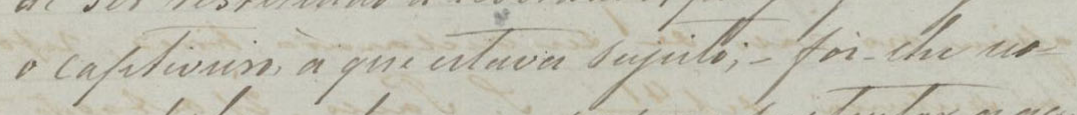

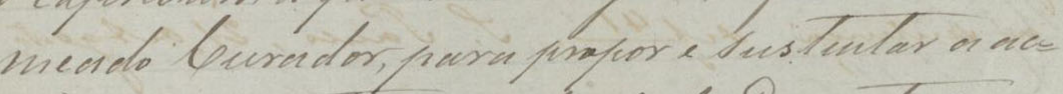

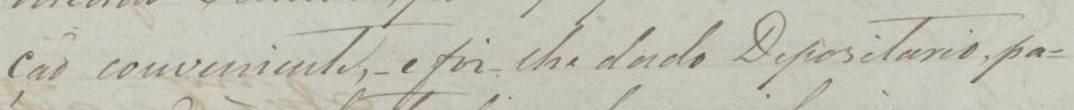

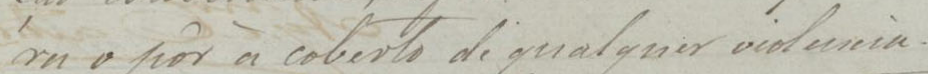

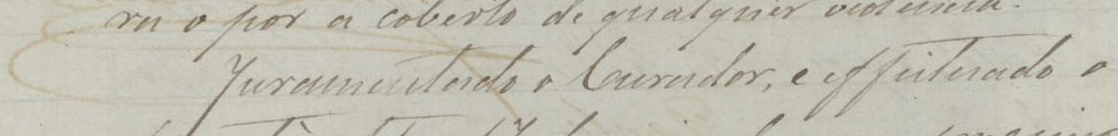

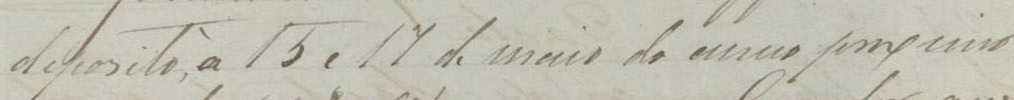

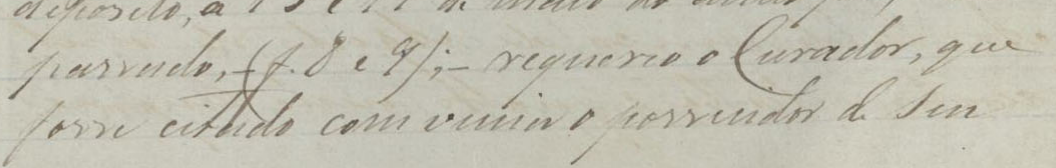


Fólio 64R

Numero $55^{17}$

\section{Relatorio}

Tendo se apresentado ao Juiz

5 Municipal do Termo de Bragança - o pardo Jozé, pedindo para se lhe fornecer os meios legais de ser restituido à liberdade, por julgar injusto o captiveiro à que estava sujeito; - foi-lhe nomeado Curador, para propor e sustentar a acçaõ conveniente, - e foi-lhe dado Depositario para o pôr à coberto de qualquer violencia.

Juramentado o Curador, e effetivado o deposito, à 15 e 17 de maio do anno [Imperio] passando, -(folhas 8 e 9), - requerer o Curador, que fosse citado com (ilegível) o possuidor de seo

17 Este fólio possui, na primeira parte, anotações de terceiro, que não foram editadas 


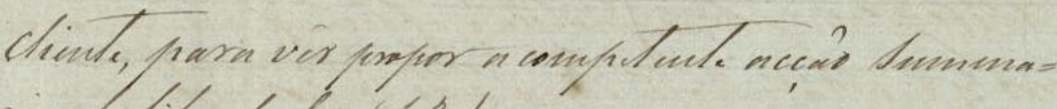
rien de liberdude:-(7.3).

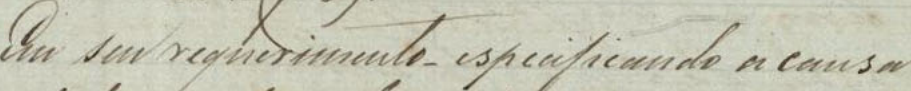

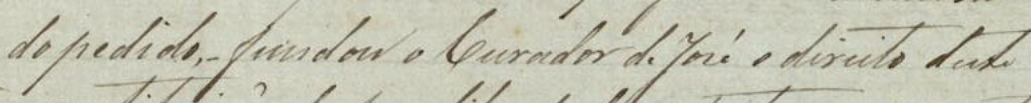

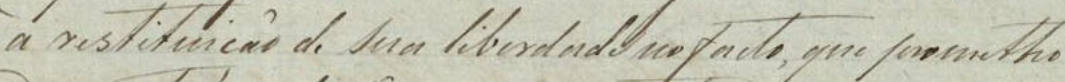

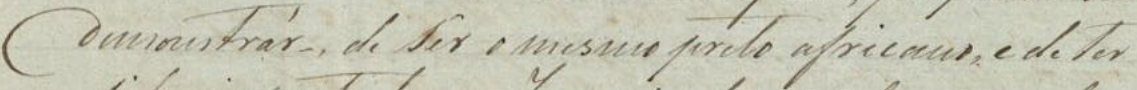

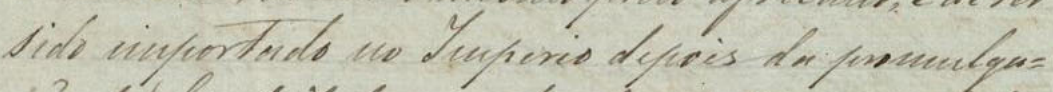

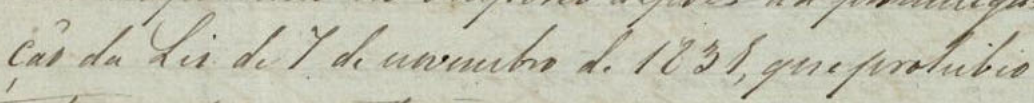
- trafied esemeratum: $-(2.3)$

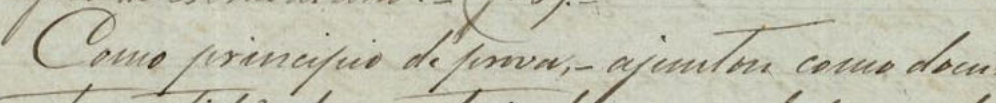

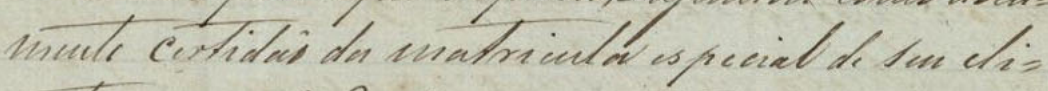

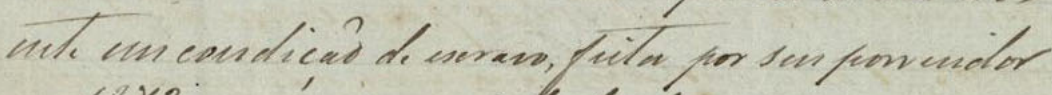

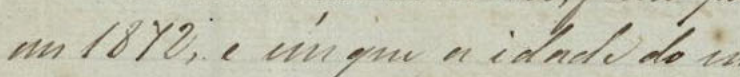

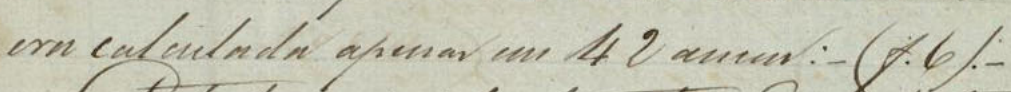

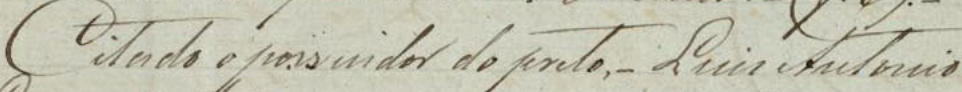

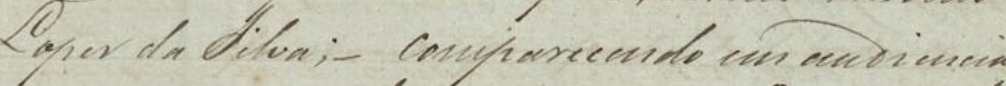

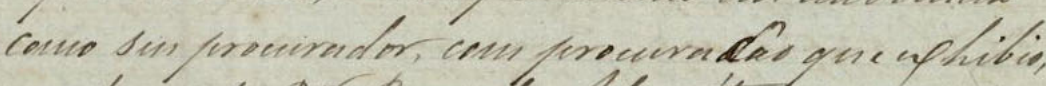

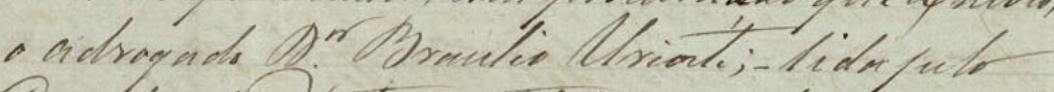

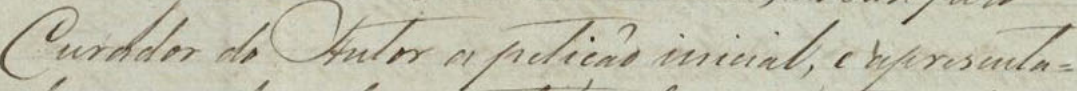

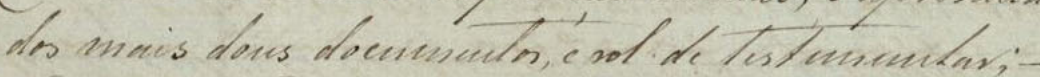

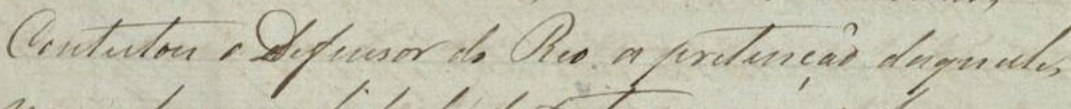

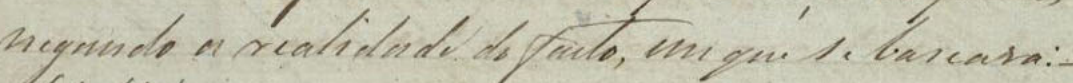
$-1.13 .1$.

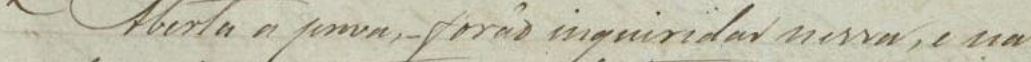

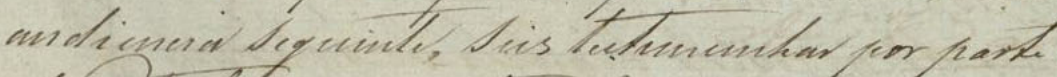

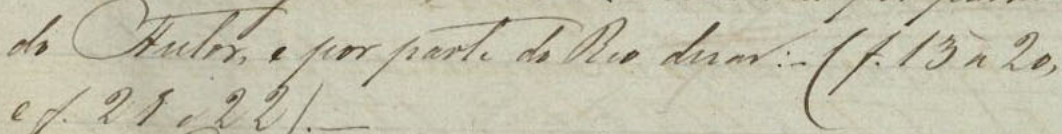

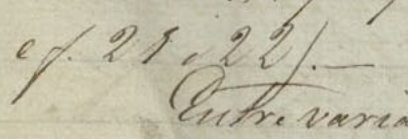

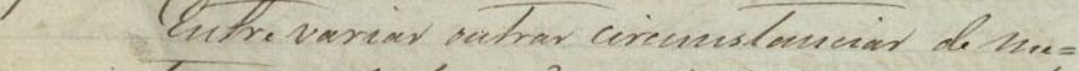

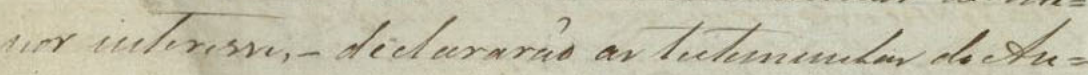


Fólio 64V

cliente, para vir propor a competente acçaõ Summaria de liberdade: -(folhas 3).

Em seu requerimento - especificando a causa do pedido, - fundou o Curador de José o direito deste

5 à restituiçaõ de sua liberdade no facto, que (prometho) demonstrár - , de sêr o mesmo pardo africano, e de ter sido importado no Imperio depois da promulgaçaõ da Lei de 7 de novembro de 1831, que prohibio o trafico de escravatura: - (folhas 3).Como principio de prova, - ajuntou como docu= mento certidaõ de matricula especial de seu di= reito em condiçaõ de escravo, feita por seu possuidor em 1872, e em que a idade do mesmo escravo era calculada apenas em 42 annos: - (folhas 6).Citado o possuidor do preto, - Luis Antonio Lopes da Silva; - comparecendo em audiencia como seu procurador, com procuraçaõ que exhibio, o advogado Doutor Braulio (Alxiorte); - lidos pelo Curador do Autor a petiçaõ inicial, e apresenta= dos mais dous documentos, e rol de testemunhas; Contestou o defensor do Reo a pretençaõ daquele, negando a realidade do feito, em que se baseara:-(folhas 13).-

Aberta prova, - foraõ inquiridas nessa, e na audiencia seguinte, seis testemunhas por parte do Autor e por parte do Reo duas: - (folhas 13 à 20, e folhas 21 e 22).-

Entre varias outras circunstancias de va $=$ rios interesses, - declararaõ as testemunhas do $\mathrm{Au}=$ 


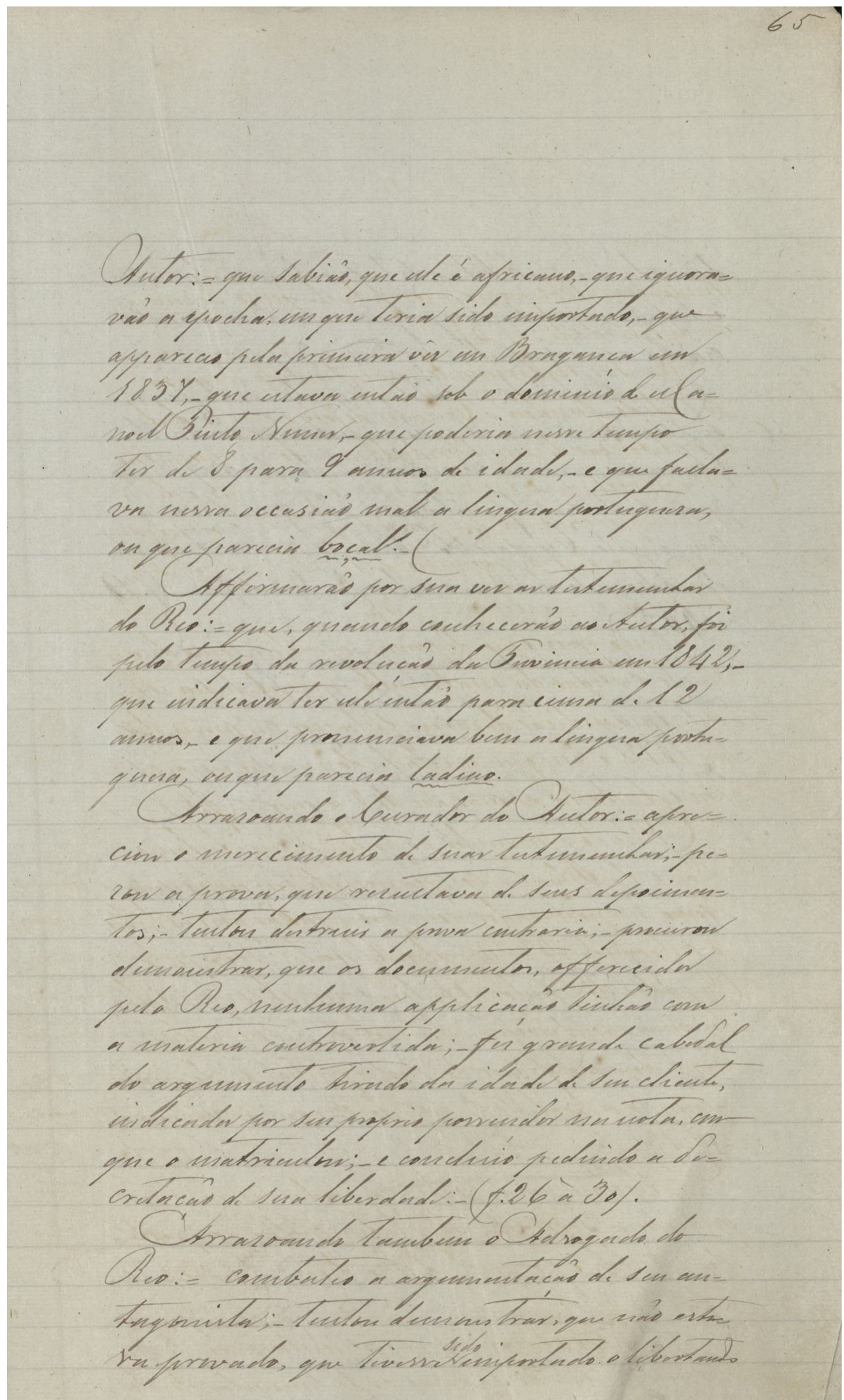


Fólio 65R

Autor: =que sabiaõ, que elle é africano, - que ignora= vaõ a epocha em que teria sido importado, - que appareceo pela primeira vêz em Bragança em 1837, -que estava entaõ sob o dominio de $\mathrm{Ma}=$ 5 noel Pinto Nunes, - que poderia nesse tempo ter de 8 para 9 annos de idade, - e que falla= va nessa occasiaõ mal a lingua portuguesa, vez que parecia boçal.

Affirmaraõ por sua vez as testemunhas do Reo:= que, quando conheceraõ ao Autor, foi pelo tempo da revoluçaõ da Provincia em 1842,que indicava ter elle entaõ para cima de 12 annos, e que pronunciava bem a lingua portuguesa, vez que parecia ladino.

Arrazoando o Curador do Autor:=apre= ciou o merecimento de suas testemunhas;-pe= sou a prova que resultava de seus depoimen= tos; - tentou destruir a prova contraria;- procurou demonstrar, que os documentos, offerecidos pelo Reo, nenhuma applicaçaõ tinhaõ com a materia controvertida; - fez grande cabedal do argumento tirado da idade de seu cliente, indicada por seu proprio possuidor na nota, em que o matriculou;- e concluio pedindo a de= cretaçaõ de sua liberdade:-(folhas 26 à 30).

Arrazoando tambem o Advogado do Reo:= combateo a argumentaçaõ de seu an= tagonista; - tentou demonstrar, que naõ estava provado, que tivesse sido importado o libertando 
DOC 6

121

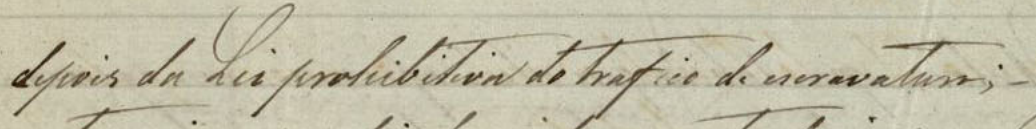

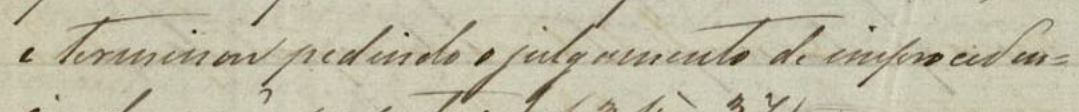

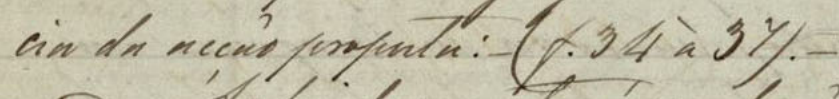

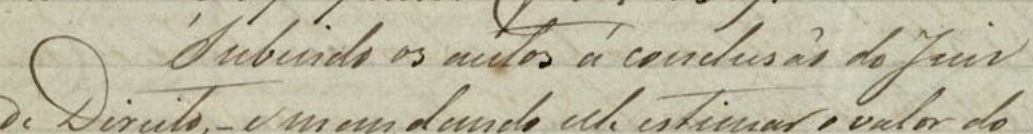

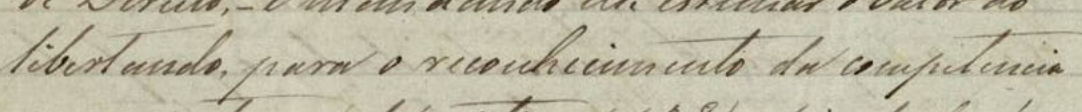

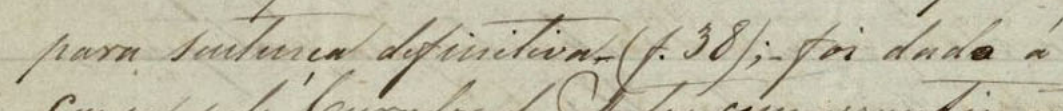

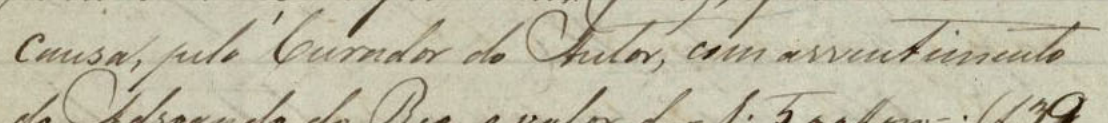

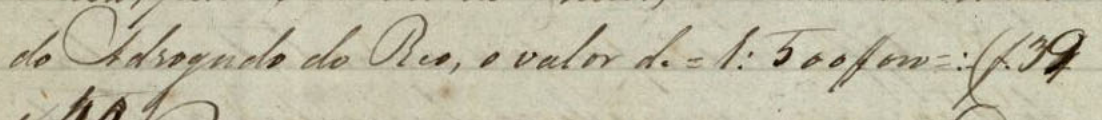
$40 \%$

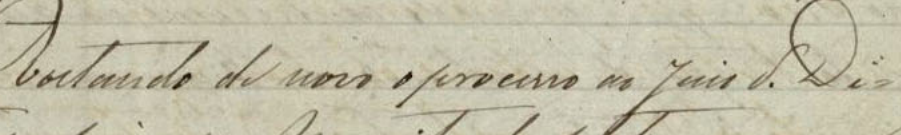

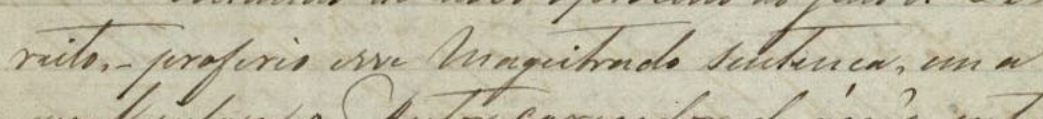

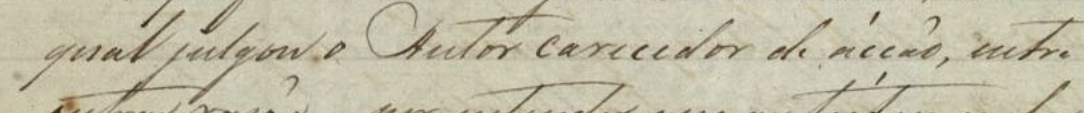

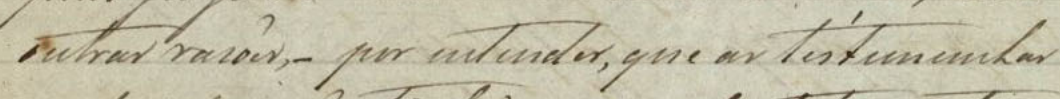

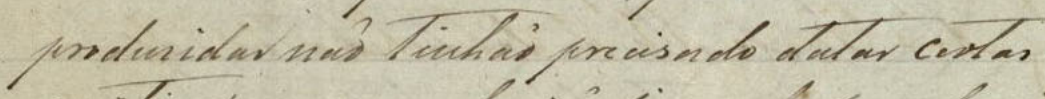

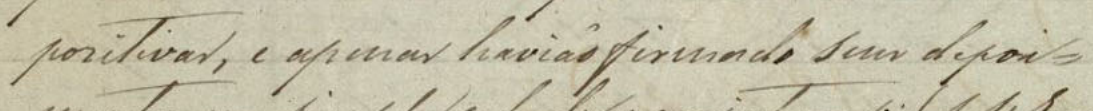

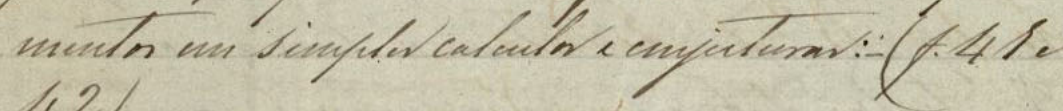
$42 \%$

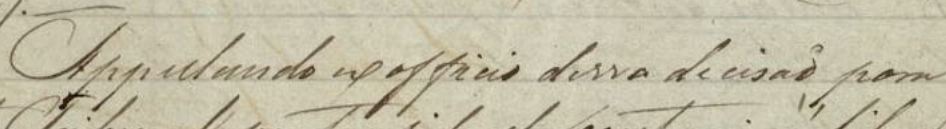

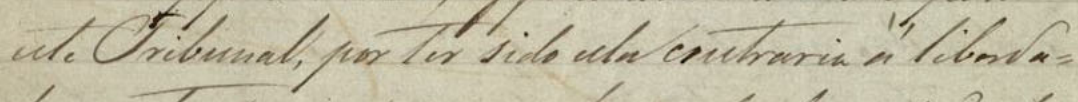

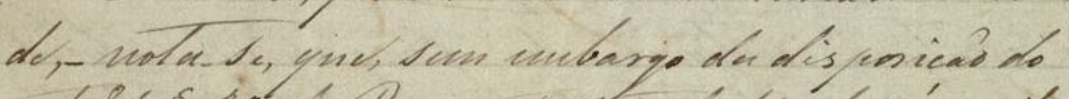

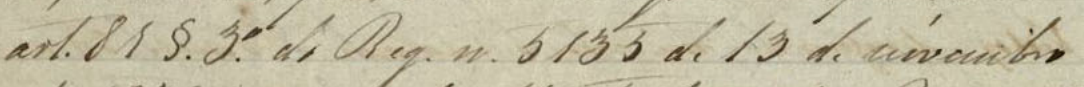

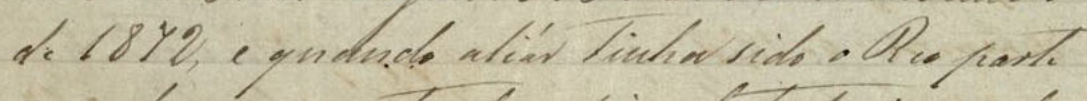

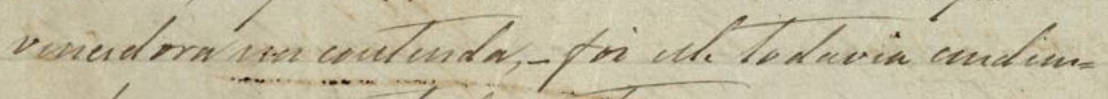

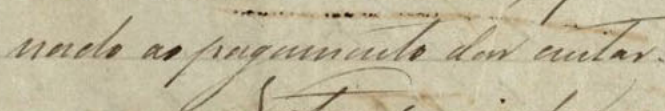

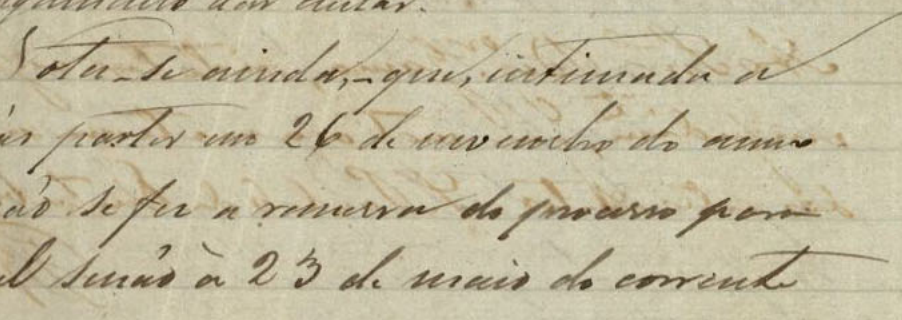


Fólio 65V

depois da Lei prohibitiva do trafico de escravatura;e terminou pedindo o julgamento de improceden= cia da acçaõ proposta: - (folhas 34 à 37).-

Subindo os autos à conclusaõ do Juiz

5 de Direito, - e mandando elle estimar o valor do libertando, para o reconhecimento da competencia para sentença definitiva - (folhas 38); foi dado á causa, pelo Curador do Autor, com assentimento do Advogado do Reo, o valor de 1:500,000 (folhas 39 e 40).

Voltando de novo o processo ao juiz de $\mathrm{Di}=$ reito,- proferio esse Magistrado sentença, em a qual julgou o Autor carecedor da acçaõ, entre outras rasoẽs, - por entender, que as testemunhas produsidas naõ tinhaõ precisado datas certas e positivas, e apenas haviaõ firmado seus depoimentos em simples calculos e conjecturas:-(folhas $41 \mathrm{e}$ 42).-

Appelando ex officio dessa decisaõ para este Tribunal, por ter sido esta contraria á liberda= de, - nota-se, que sem embargo da disposiçaõ do artigo $81 \S 3^{\circ}$ do Regimento número 5135 de 13 de novembro de 1872, e quando aliás tinha sido o Reo parte vencedora na contenda, - foi elle todavia conden $=$ nado ao pagamento das custas.

Nota-se ainda, - que, intimada da sentença as partes em 26 de novembro do anno findo, naõ se fez a remessa do processo para o Tribunal senaõ à 23 de maio do corrente 


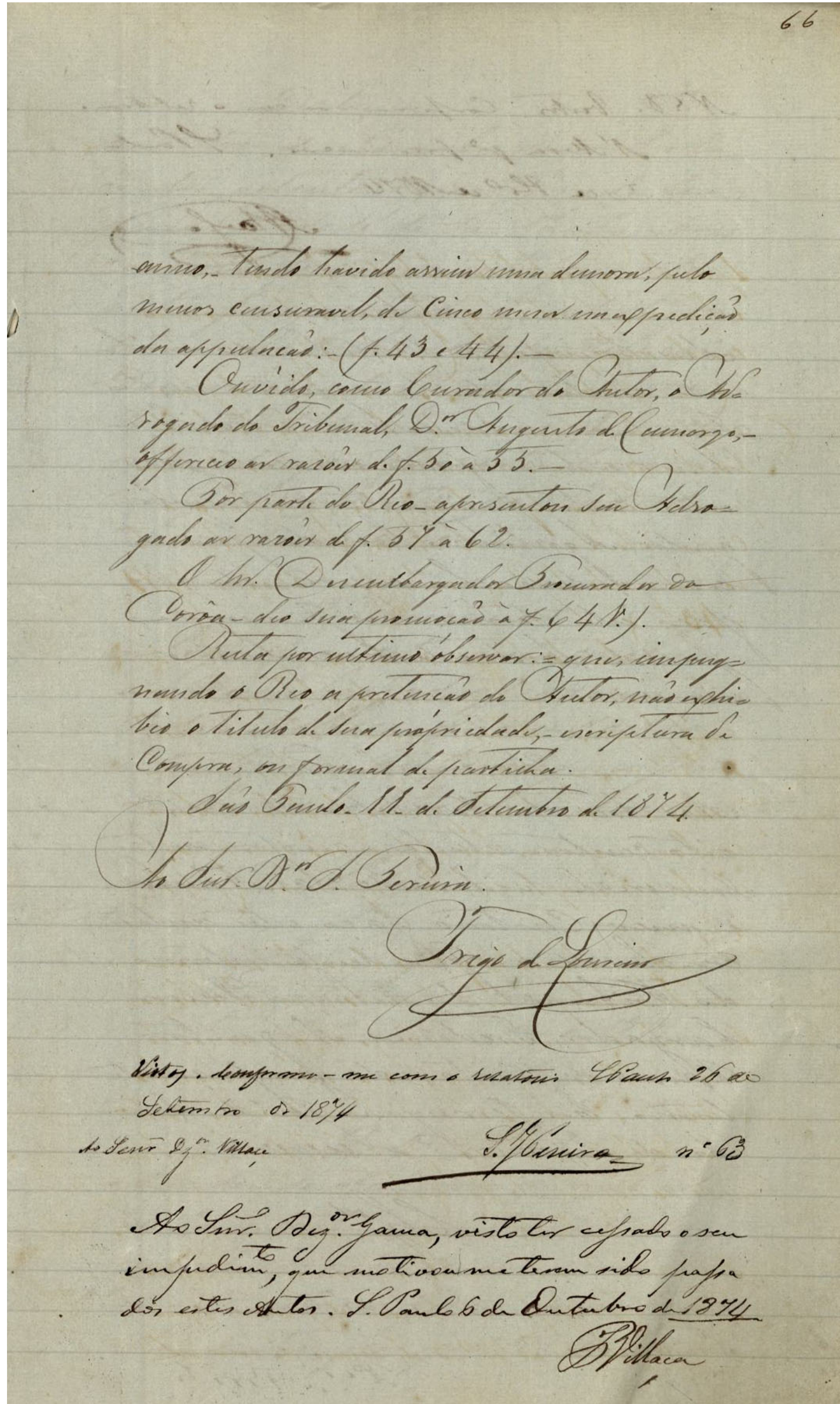


Fólio 66R

anno, - tendo havido assim uma demora, pelo

menos sensuravel, de Cinco meses na expediçaõ

da appelaçaõ:-(folhas 43 e 44).-

Ouvido, como Curador do Autor, o $\mathrm{Ad}=$

5 vogado do Tribunal, Doutor Augusto de Camargo,-

offereceo as rasoẽs de folhas 50 a 55 .-

Por parte do Reo - apresentou seu Advo=

gado as rasoẽs de folhas 57 à 62 .

O Senhor Desembargador Procurador da

10 Corôa - deo sua procuraçaõ à folhas 64 Verso.

Resta por ultimo observar: = que impug=

nando o Reo a pretençaõ do Autor, naõ exhi=

bio o titulo de sua propriedade, - escriptura de

compra, ou formal de partilha.

15 Saõ Paulo, 11 de Setembro de 1874.

Ao Senhor Desembargador Doutor Pereira

Trigo de Loureiro

Vistos. Conformo-me com o relatorio. Saõ Paulo, 26 de

Setembro de 1874.

20

Ao Senhor Dezembargador Villaça $\quad$ Pereira número 6318

18 Este fólio possui, a seguir, anotações de terceiro, que não foram editadas 


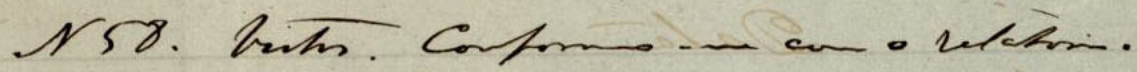
s'ara pémitumin. Ylates

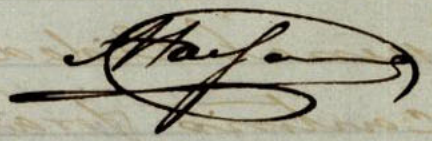

\section{siblececal}

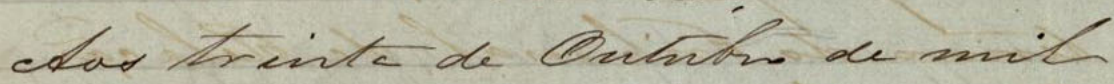
wits evels ecturta equatso werta

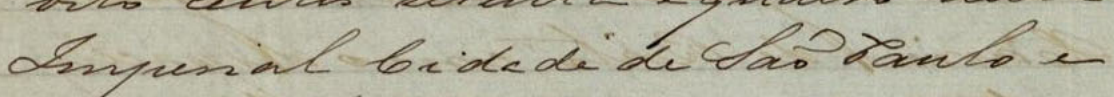
sue cartwio fler of nue whigever wes auth thr parte do Secuban

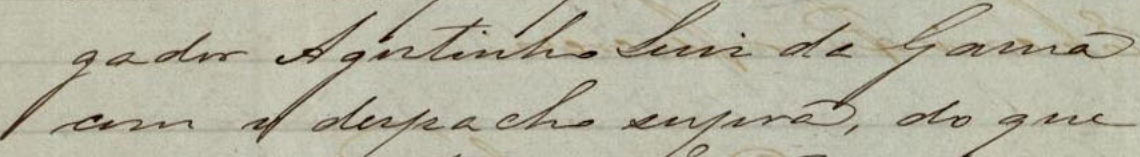

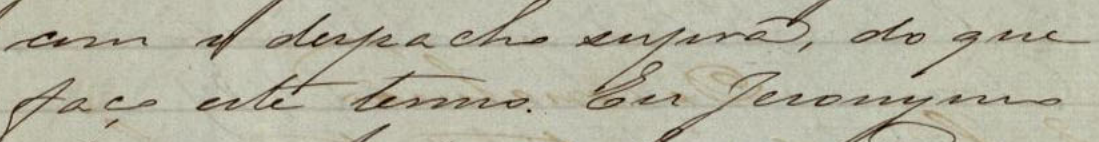

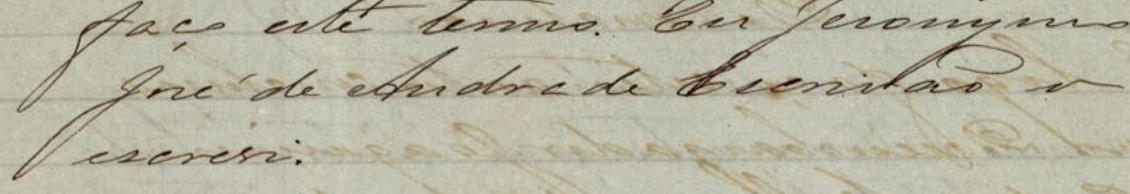
(

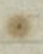

$$
\text { Q } 2 \text { concturato }
$$

equer thes de eltoventor de mil nito cuntur eterte equatso mete

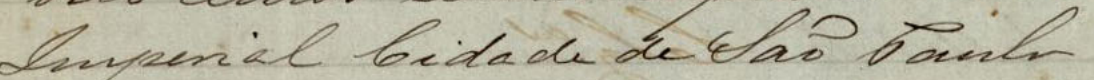

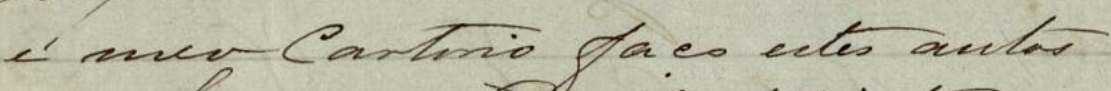

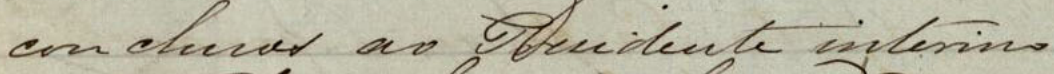

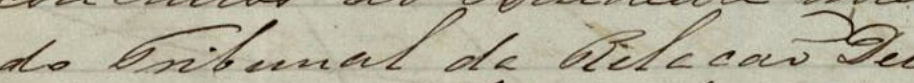
f

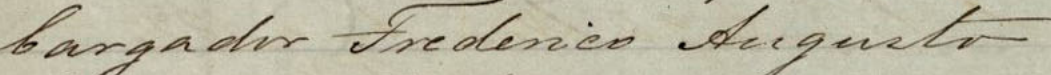

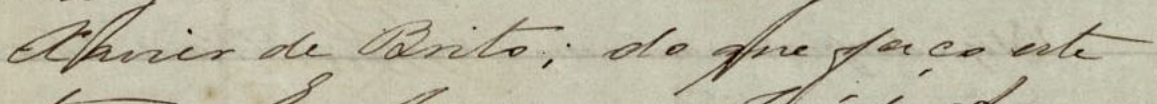

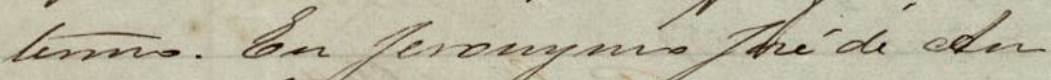

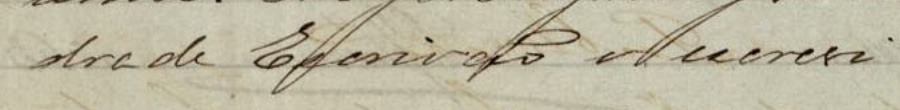

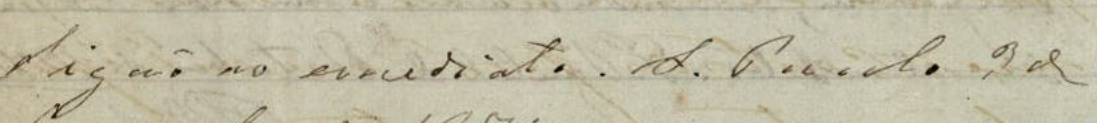

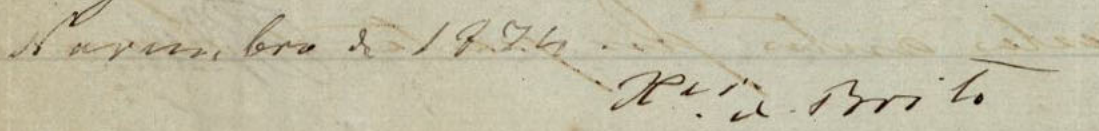


Fólio 66V

Numero 58. Vistos. Conformo-me com o relatorio.

À mesa para providencias. Saõ Paulo

30 de Outubro de 1874.

Agostinho Luiz da Gama 


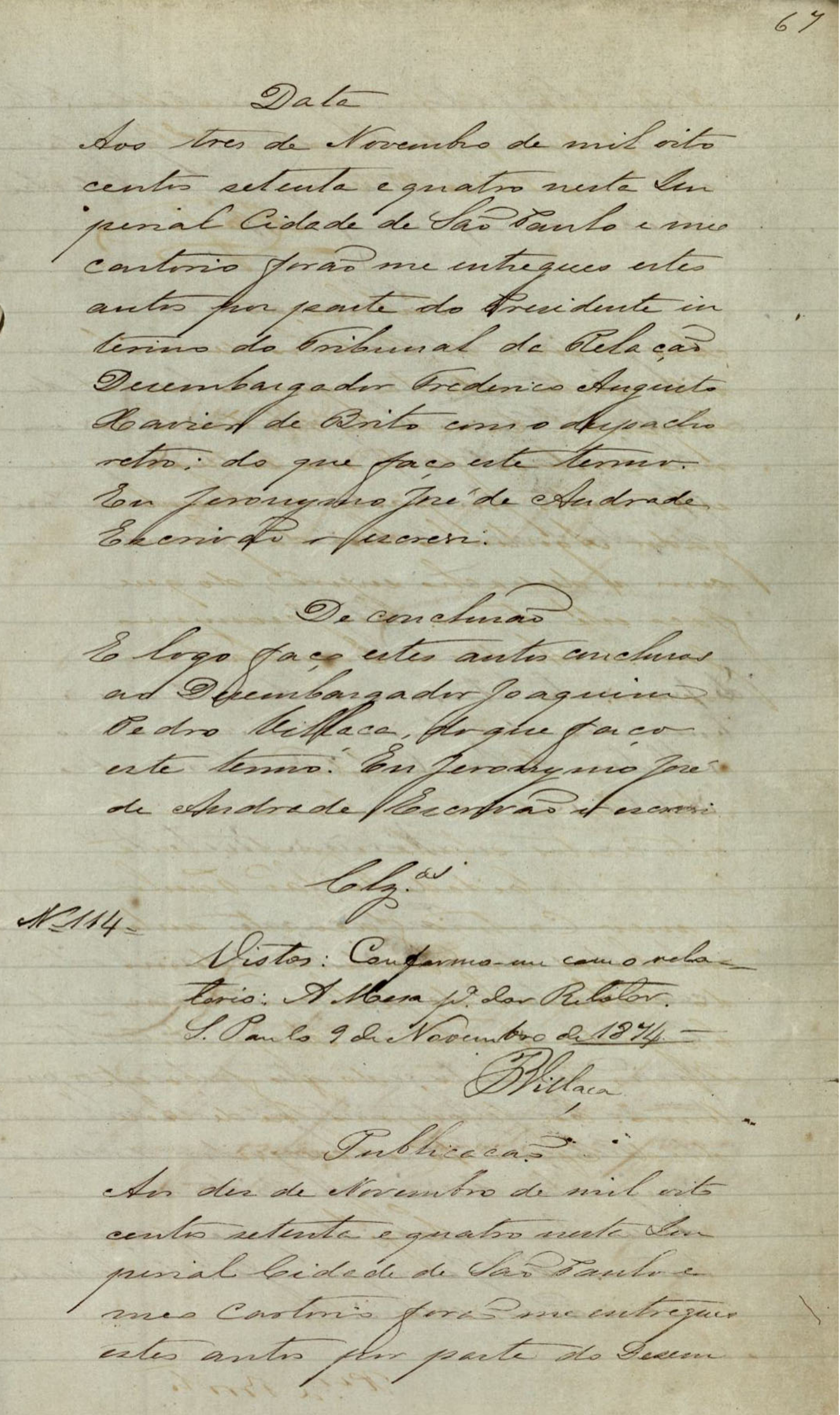


Fólio 67R 19

Numero 114

Vistos: Conformo-me com o rela-

torio. A Mesa para dar Relator.

Saõ Paulo 9 de Novembo de 1874.

5 Villaça ${ }^{20}$

${ }^{19}$ Este fólio possui, nesta primeira parte, anotações de terceiro, que não foram editadas

${ }^{20}$ Este fólio possui, a seguir, anotações de terceiro, que não foram editadas 
DOC 6

129

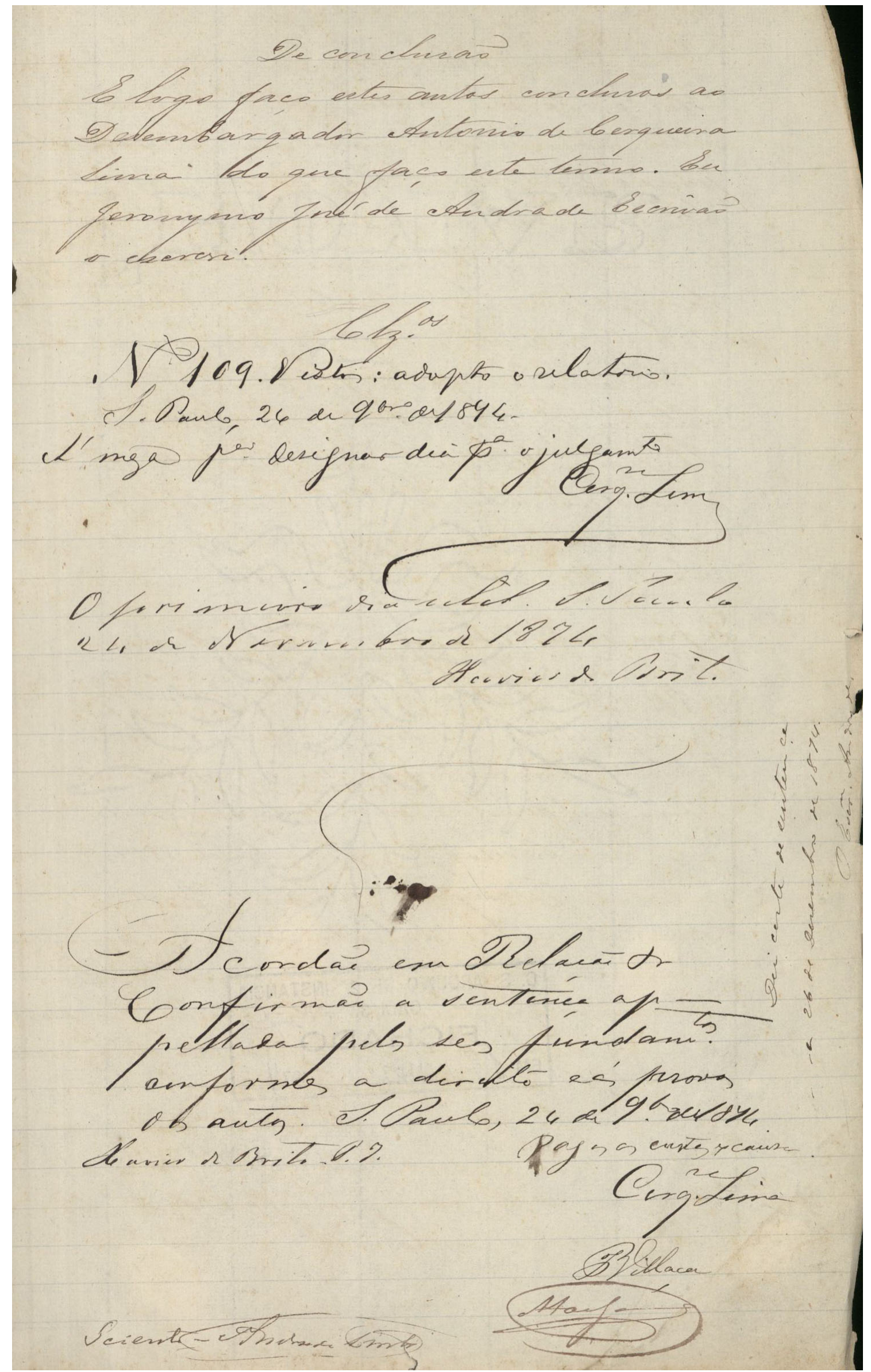


Fólio 68R

Numero 109 Vistos: adopto o relatorio.

Saõ Paulo, 26 de Novembro de 1874.

Á Meza para designar dia para o julgamento.

\section{Cerqueira Lima ${ }^{21}$}

5

Acordaõ em Relaçaõ (ilegível)

Confirmaõ a sentença ap-

pellada pelos seos fundamentos

conformes a direito e ás provas

10 dos autos. Saõ Paulo, 26 de Novembro de 1874.

Xavier de Brito P. J. ${ }^{22}$

Cerqueira Lima

Villaça

Gama ${ }^{23}$

15

${ }^{21}$ Este fólio possui, a seguir, anotações de terceiro, que não foram editadas

22 Este fólio possui, nesta linha, anotações de terceiro, que não foram editadas

23 Este fólio possui, a seguir e na lateral e transversal, anotações de terceiro, que não foram editadas 


\subsection{DOC 7}

Documento: Sentença

Remetente: juiz ordinário representando a Justiça Estadual de São Paulo - $1^{\text {o }}$ grau

Local: Paraibuna

Processo: $81 / 1874$

Juiz: Virgílio de Siqueira Cardozo

Destinatários:

Autores: Escravos Guerino e outros (Antonio, Benedcito, Porcina, Rosa e João)

Réu: Espólio da finada Dona Teodora Lima de Toledo

Data: 28 de fevereiro de 1874

Descrição: 4 fólios- páginas 84 verso, 85 recto e verso e 86 recto, anotados por apenas um punho, o próprio juiz proferidor da decisão. Trata-se de uma ação de liberdade intentada por seis escravos autores, que pretendem a liberdade baseados em declaração verbal da intenção de libertá-los da ex-senhora falecida. Sentença que julga improcedente o pedido dos autores, os julgando carecedores do direito de liberdade por falta de provas, confirmando suas situações de escravos pertecentes ao acervo a ser partilhado entre os herdeiros. 


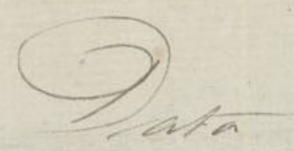

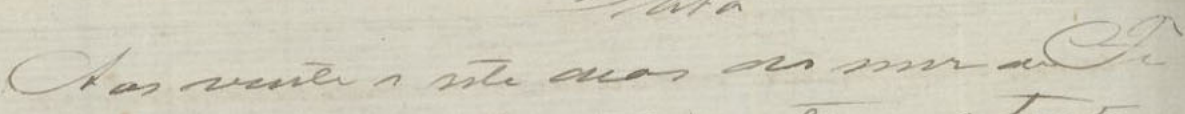

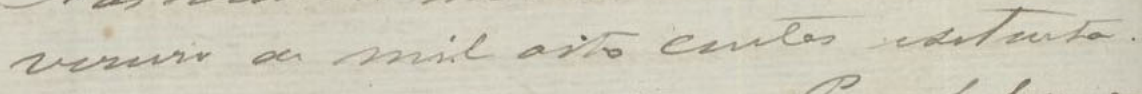

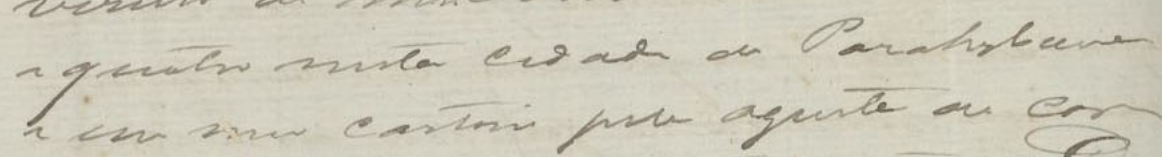

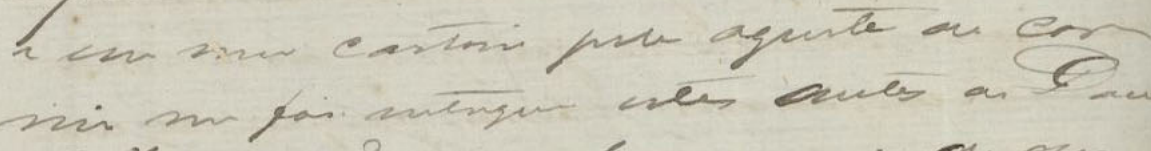

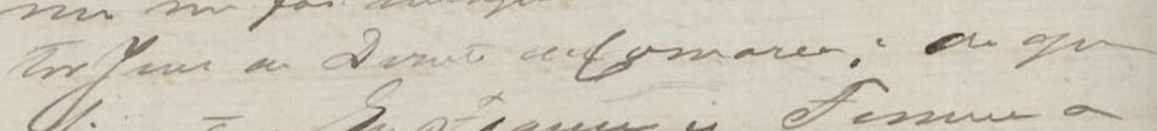

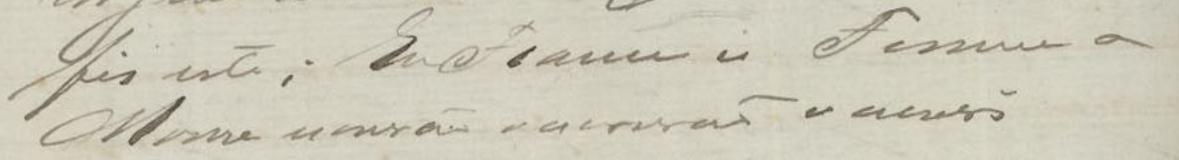

\section{$\operatorname{lic}^{2}$}

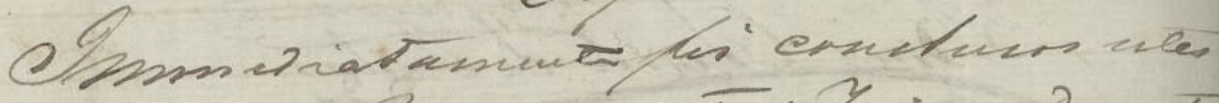

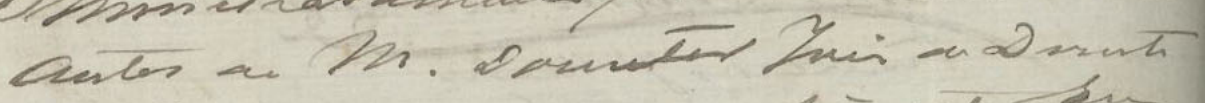

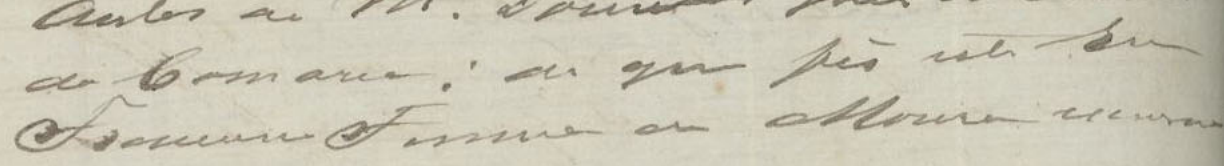
- cesur.

\section{3}

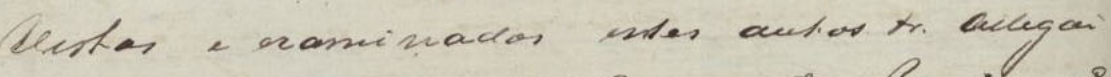

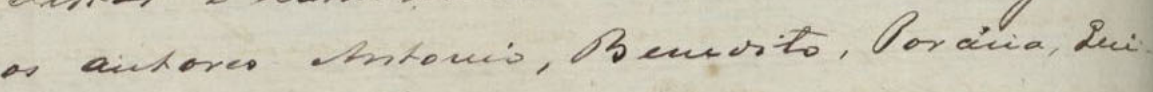

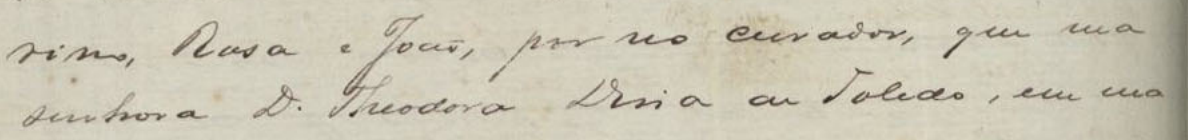
vida, mavifukára a' acosess ar jufoos aivi Lencér on litertat-o, gen una un horap.

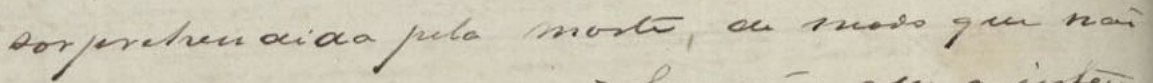

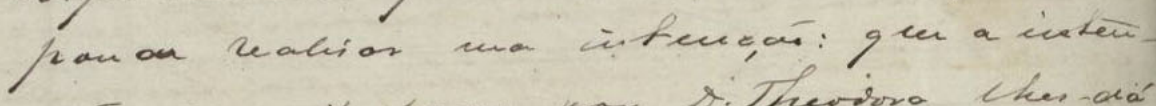

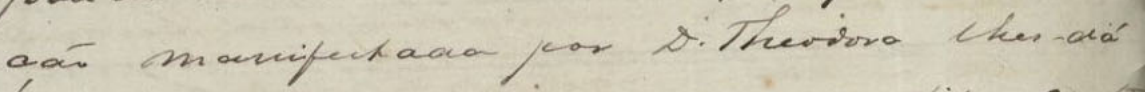

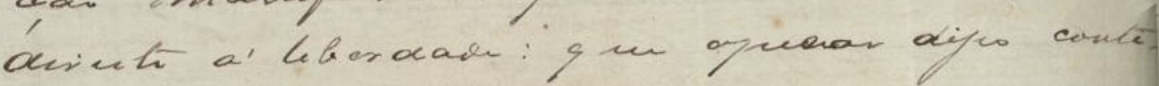

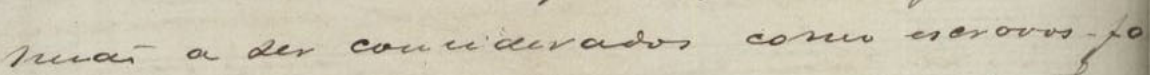

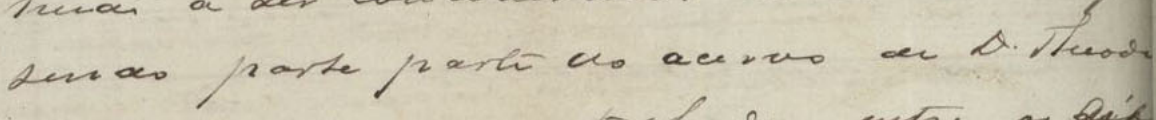

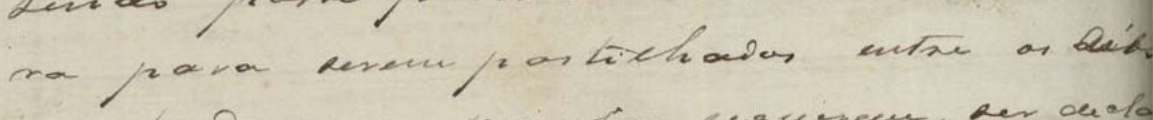

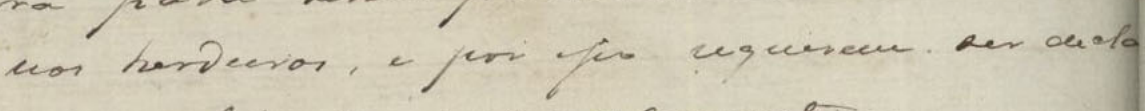
ravor libertor jurevaluever. -

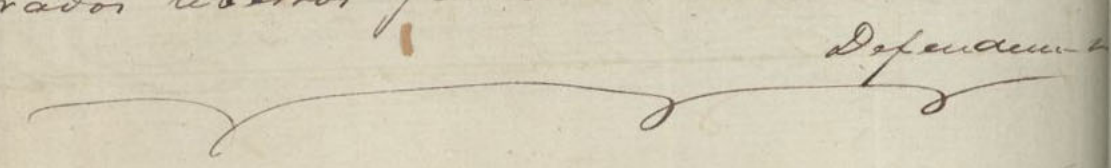


Fólio $84 \mathrm{~V}{ }^{24}$

Vistos e examinados estes autos (ilegível). Allega

os autores Antonio, Benedicto, Porcina, Gue-

rino, Rosa e Joaõ, por seo curador, que sua

senhora Dona Theodora (ilegível) de Toledo, em sua

5 vida manifestára à acoessas pessoas a in-

tençaõ de libertal-os; que sua senhora foi

sorprehendida pela morte, de modo que naõ

poude realisar sua intençaõ: que a inten-

çaõ manifestada por Dona Theodora lhes-dá

10

direito à liberdade; que apesar disso conti-

nuaõ a ser considerados como escravos - fa-

zendo parte parte do acervo de Dona Theodo-

ra para serem partilhados entre os legiti-

mos herdeiros, e por fim requerem ser decla-

15 rados libertos judicialmente. -

Defendem-se

${ }^{24}$ Este fólio possui, na metade inicial, anotações de terceiro, que não foram editadas 


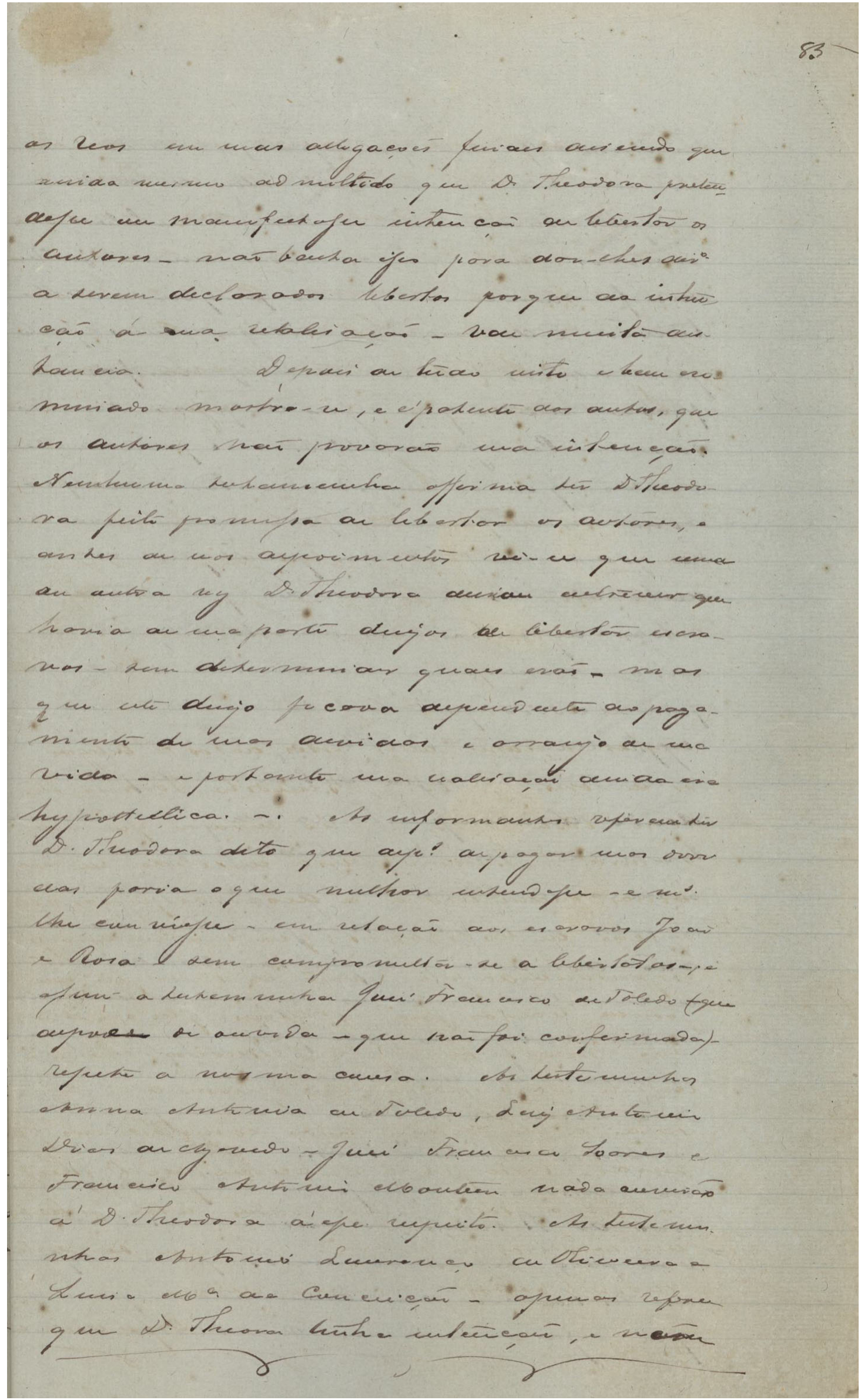


Fólio 85R

os Reos em suas allegaçoẽs finaes disendo que ainda mesmo admittido que Dona Theodora pretendesse em manifestar sua intençaõ de libertar os autores - naõ basta essa para dar-lhes (ilegível)

5 a serem declarados libertos porque da intençaõ à sua realisaçaõ - [vai] muita distancia. Depois de tudo visto e bem examinado mostra-se, e é patente dos autos, que os autores naõ provaraõ sua intençaõ.

Nenhuma testemunha affirma ter Dona Theodora feito promessa de libertar os autores, e antes de seos depoimentos vê-se que uma ou outra vez Dona Theodora deixou entender que havia de sua parte desejos de libertar escravos - sem determinar quais eraõ - mas que este desejo ficava dependente ao pagamento de suas dividas e [arranjo] de sua vida - e portando uma realisaçaõ ainda era hypottéttica. - : As informantes (affirmam) ter Dona Theodora dito que (depois) de pagar suas dividas faria o que melhor entendesse - e (ilegível) lhe cumprisse - em relaçaõ aos escravos Joaõ e Rosa e sem comprometer-se a libertalos - e assim a testemunha José Francisco de Toledo (- que depoes de ouvida - que naõ foi confirmada)repete a mesma cousa. As testemunhas Anna Antonia de Toledo, Luis Antonio Dias de Azevedo - Luis Francisco Soares e Francisco Antonio Monteiro nada ouviraõ d'e Dona Theodora a esse respeito. As testemunhas Antonio Lourenço de Oliveira e Luisa Maria da Conceiçaõ - apenas referem que Dona Theodora tinha intençaõ, e naõ 


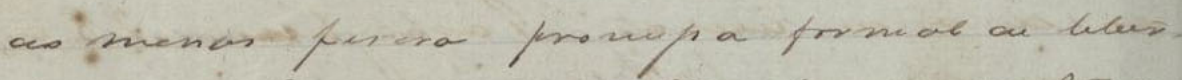

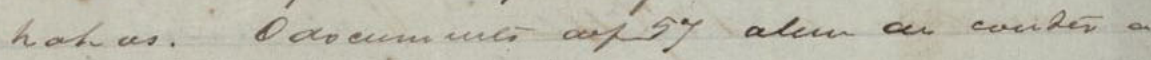

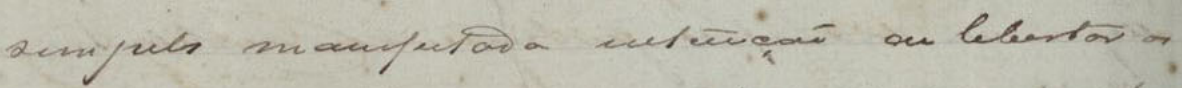

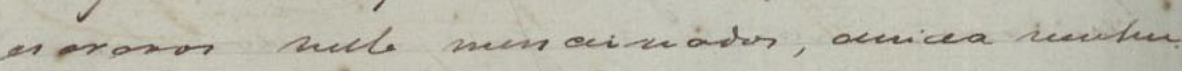

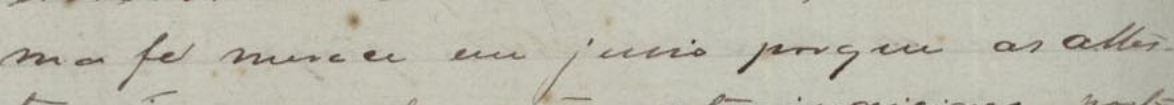

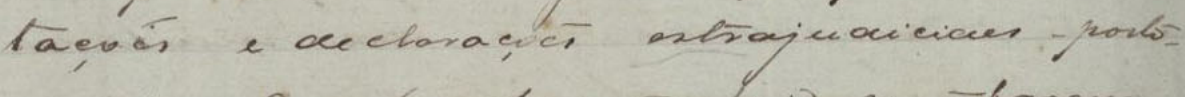

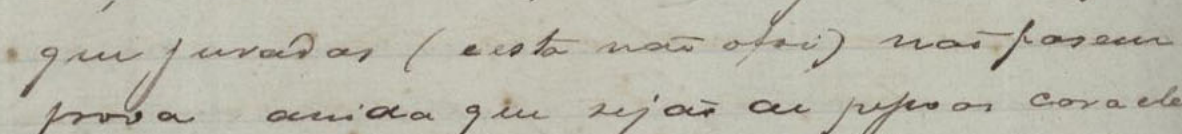

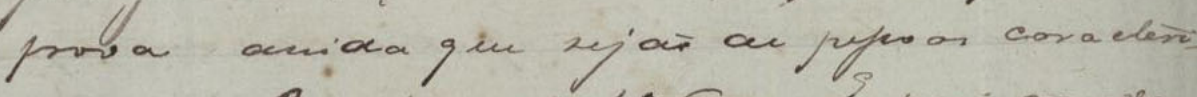

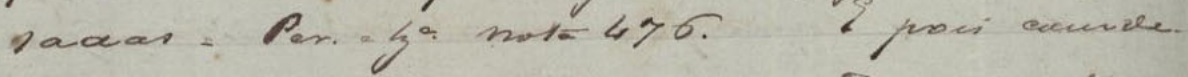

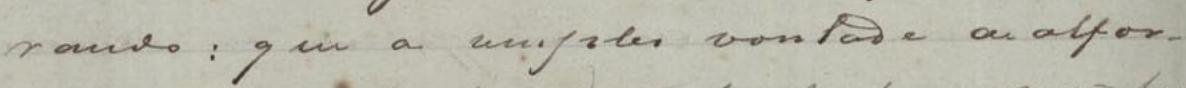
niar movificutara futa Luter mar bas

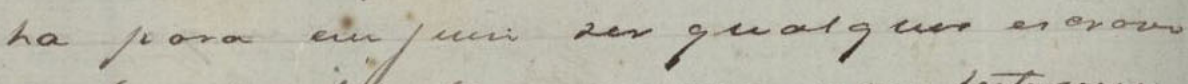

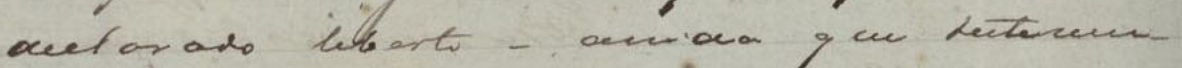

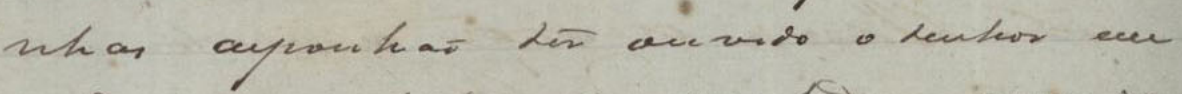

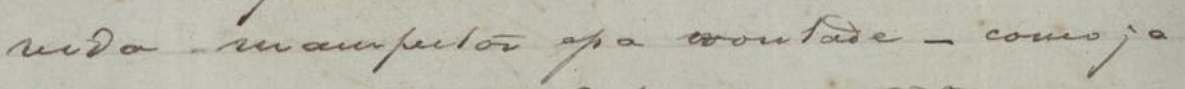

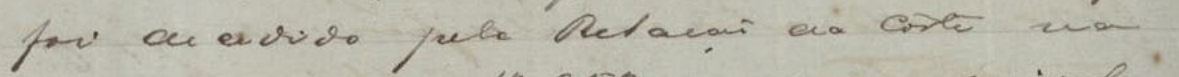

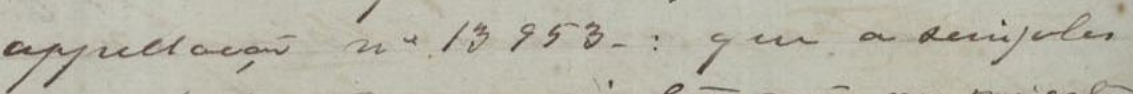

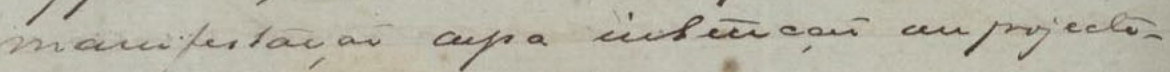

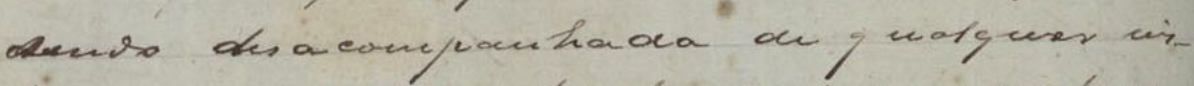

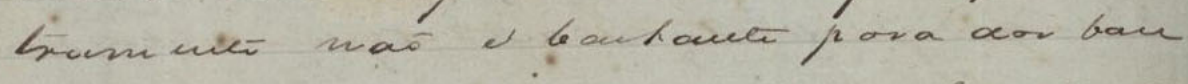

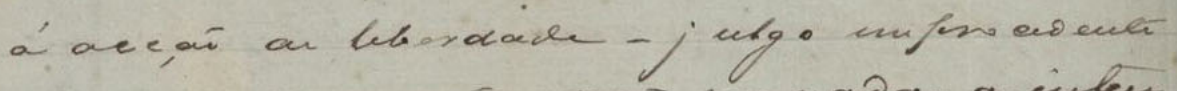

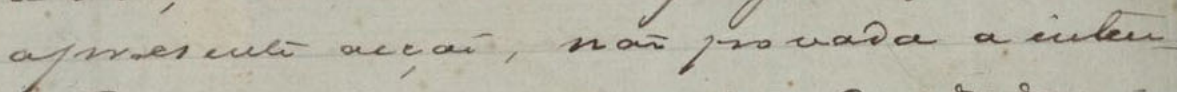

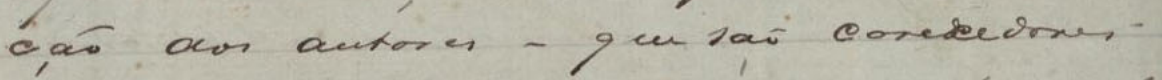

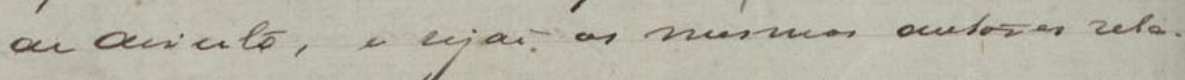

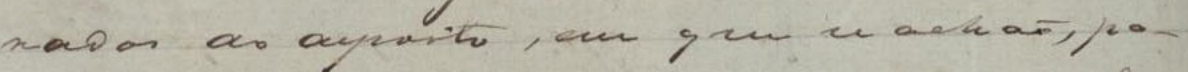

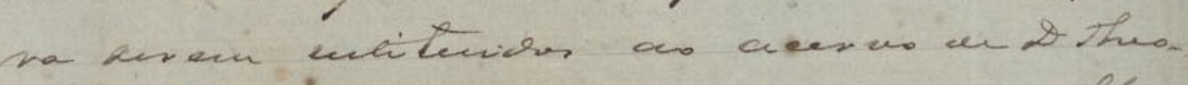

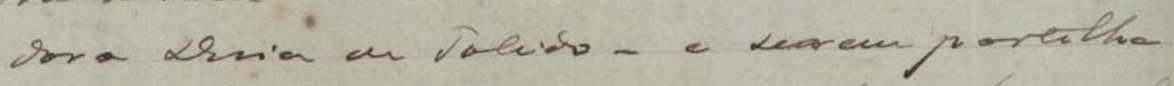

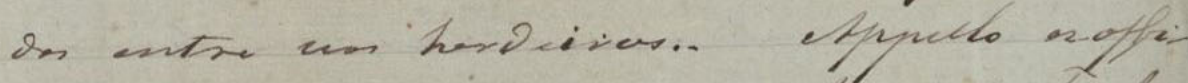

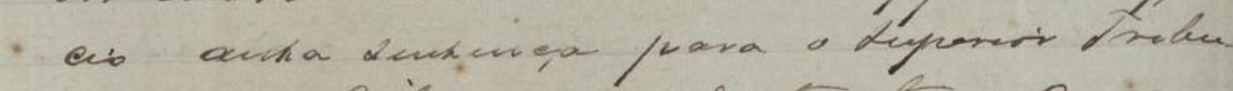

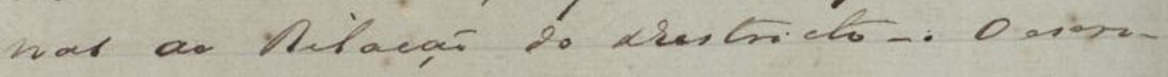
ver face hequi as cuetor fiona a hege.

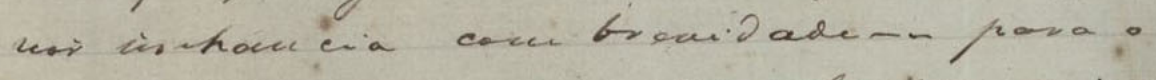

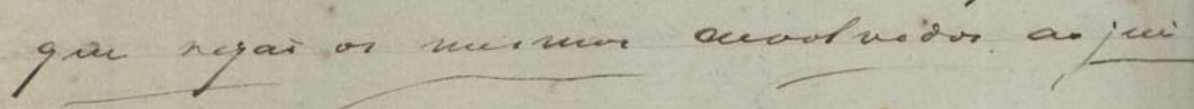


Fólio 85V

ao menos fizera promessa formal de liber-

tal-as. Documento defolhas57 além de conter a

simples manifestada intençaõ de libertar os

escravos nelle mencionados, ainda (ilegível)

5 ma fé nunca em juiso porque as [attes-]

tações e declaraçoẽs extrajudiciaes - [posto]

que juradas(e esta naõ assi) naõ fazem

prova ainda que sejaõ de pessoas (carateri-)

sadas - Por. (ilegível) nota 476. E pois conside-

rando: que a simples vontade de alfor-

riar manifestada pelo senhor naõ bas-

ta para em juiso ser qualquer escravo

declarado liberto - ainda que testemu-

nhas apontaõ ter ouvido o senhor em

vida manifestar essa vontade - como ja

foi decidido pela Relaçaõ da Corte na

appellaçaõ número 13953-: que a simples

manifestaçaõ cuja intençaõ em projecto -

sendo desacompanhada de qualquer tes-

tamento naõ é bastante para dar base

à acçaõ de liberdade - julgo improcedente

apresente acçaõ, naõ provada a inten-

çaõ dos autores - que saõ carecedores

de direito, e sejaõ os mesmos autores (retor-

nados) ao deposito, em que se achaõ, pa-

ra serem restituídos ao acervo de Dona Theo-

dora Lima de Toledo - e serem partilha-

dos entre os herdeiros.- Appello ex-offi-

cio desta sentença para o Superior Tribu-

nal da Relaçaõ do Districto -. O escri-

vaõ faça seguir os autos para a supe-

rior instancia com brevidade - para o

que sejaõ os mesmos devolvidos ao jui- 


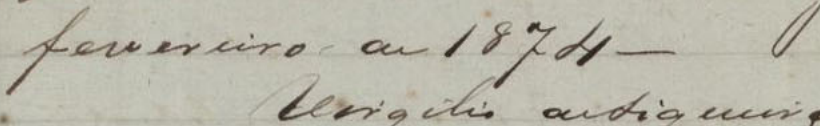

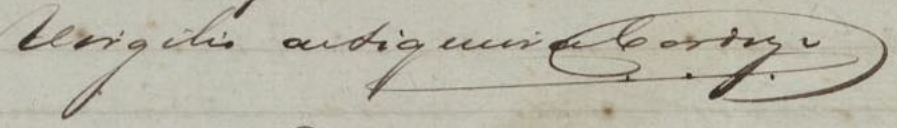

- Date

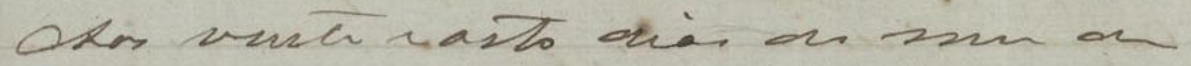

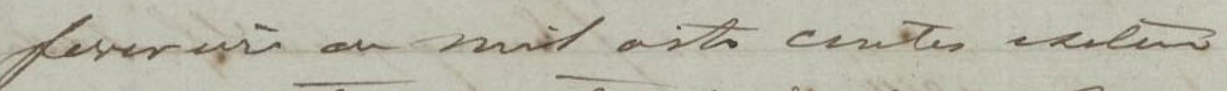

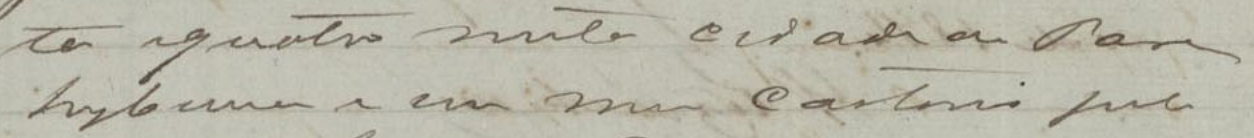

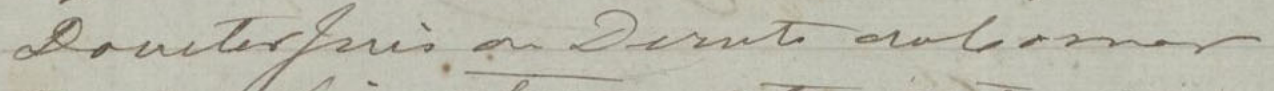

ce sulfai intuger vas dewtas. Ci

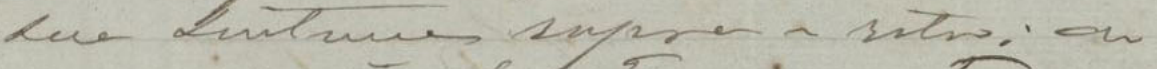

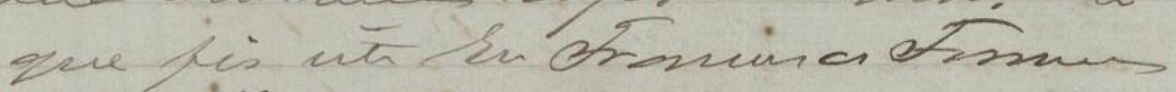

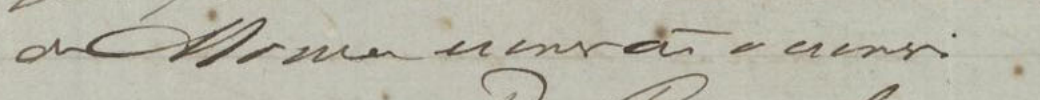

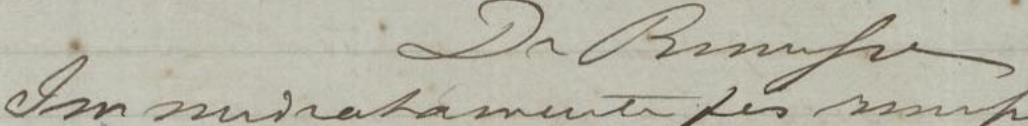

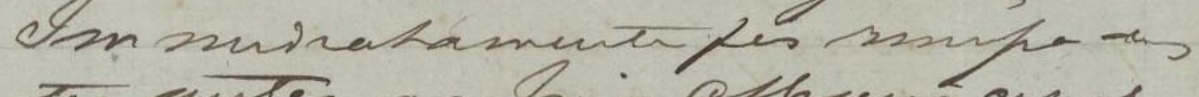

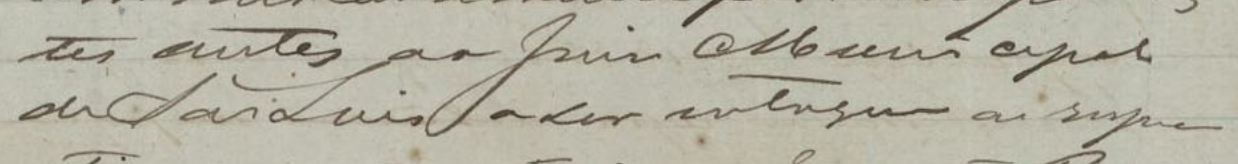

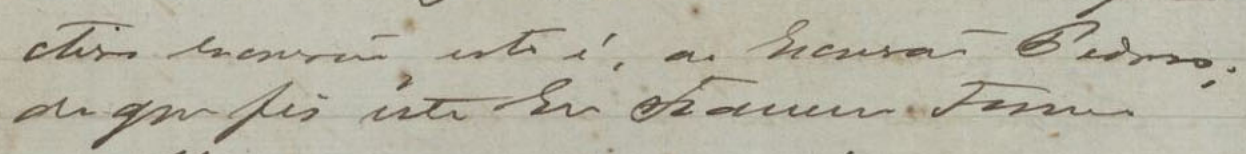

ondirue cenrai iansí

$$
\text { Demiser cirif ble }
$$

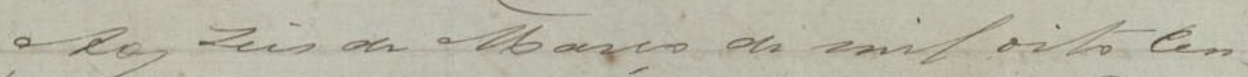

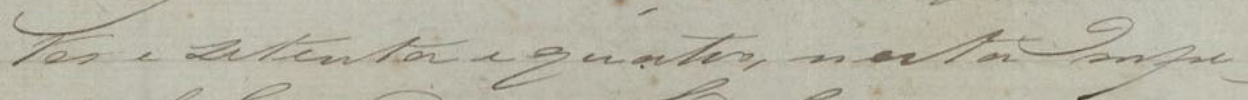

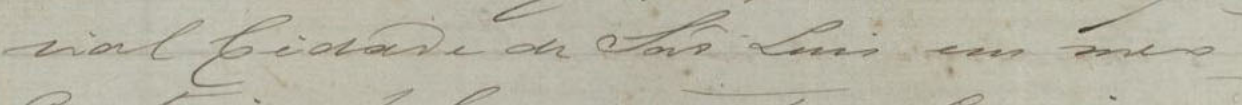

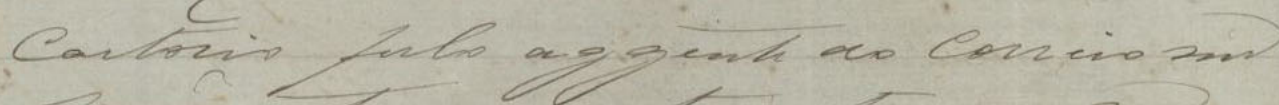

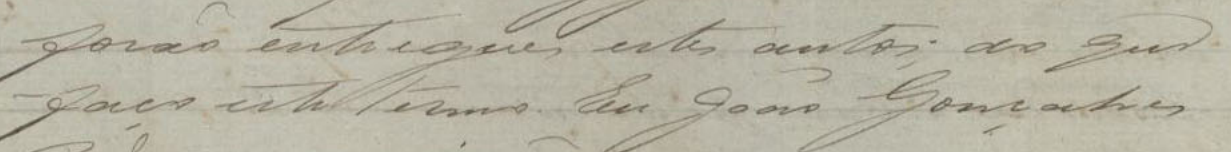

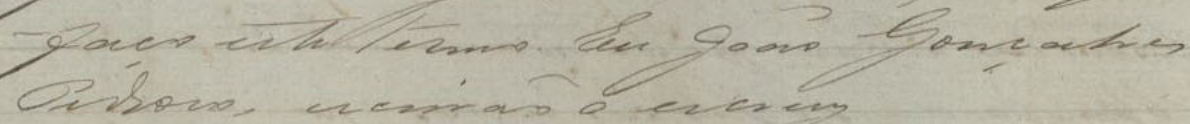

S $62 \div$

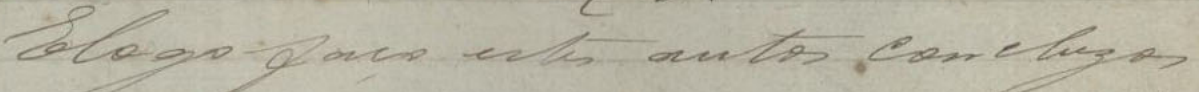


Fólio 86R

so de onde vieraõ. Parahybuna, 28 de

fevereiro de 1874 -

Virgílio de Siqueira Cardozo ${ }^{25}$

${ }^{25}$ Este fólio possui, a seguir, anotações de terceiro, que não foram editadas. 


\subsection{DOC 8}

Documento: Acórdão (relatório e decisão)

Remetentes: juízes desembargadores representando a Justiça Estadual de São Paulo Tribunal da Relação - $2^{\mathrm{O}}$ grau

Local: São Paulo

Processo: 81/1874

Destinatários:

Apelante: juiz ex officio pelos autores escravos Guerino e outros (Antonio, Benedcito, Porcina, Rosa e João)

Apelado: Espólio da finada Dona Teodora Lima de Toledo

Data: 12 de fevereiro de 1875

Desembargador Relator: Joaquim Pedro Villaça (responsável pelo Relatório)

Descrição: 3 fólios- páginas 91 recto e verso, 92 recto, sendo o relatório de um só punho, os votos pelos punhos dos respectivos desembargadores responsáveis, e a decisão pelo punho do desembargador Joaquim Pedro Villaça, confirmada pelos demais desembargadores. Trata-se de uma ação de liberdade intentada por seis escravos autores, que pretendem a liberdade baseados em declaração verbal da intenção de libertá-los da ex-senhora falecida. Sentença que julga improcedente o pedido dos autores, os julgando carecedores do direito de liberdade por falta de provas, confirmando suas situações de escravos pertecentes ao acervo a ser partilhado entre os herdeiros. O juízo apela ex officio, e o Tribunal da Relação nega provimento à apelação, confirmando a sentença apelada, pelos seus motivos. 


\section{Qe enclina?}

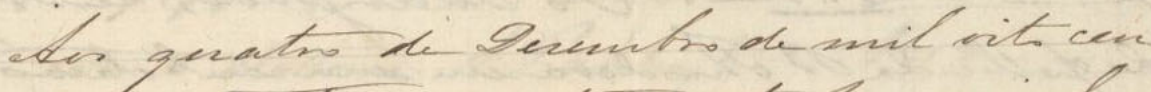

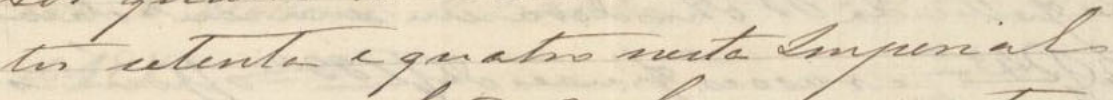
Gidede de eda Pounto e nue cartasis

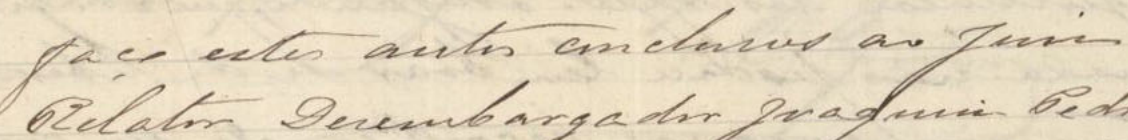
Deventargader puafuesi bedro

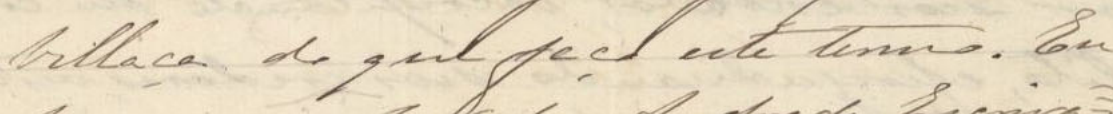

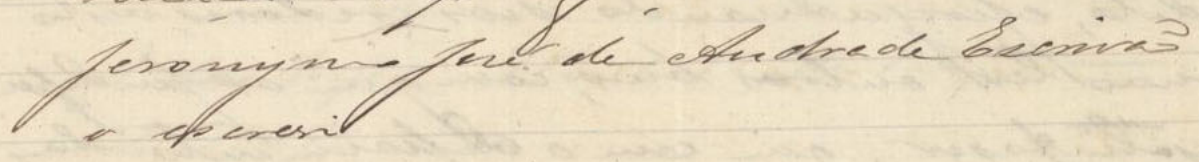
$6 \&=$

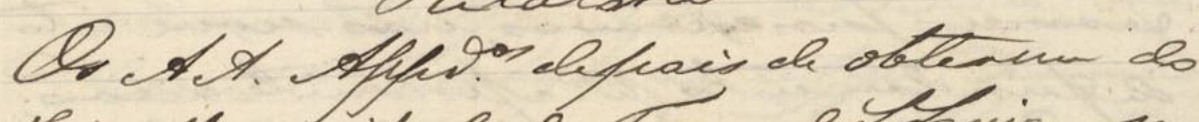
Hin thunivifual do berwoded. buir, se= numfertos em defcasits, eque we the Pefe un Curadar, ferofunerios esta accas de hiburdadal, alegands warfutácal ah

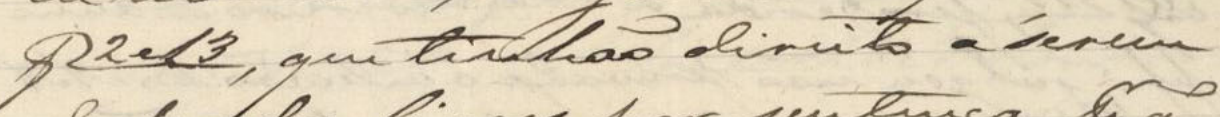

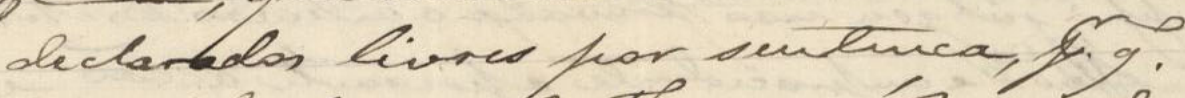

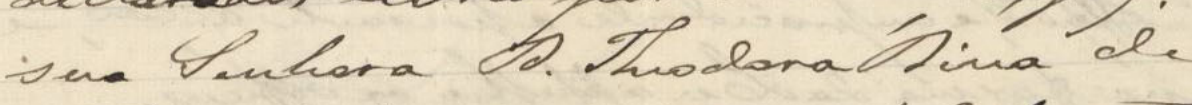
Tolids difsera fwar veses, ádiperunts fiefosas de cencuils, cribio, 9 era

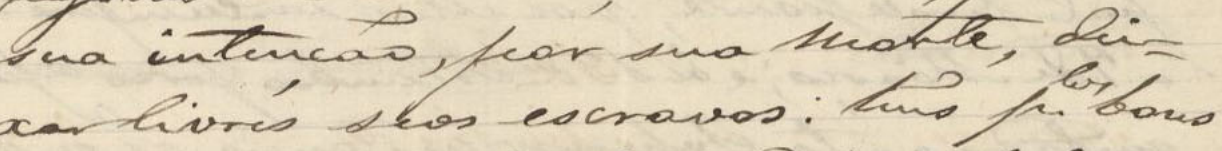
servies pere the havias fescrtads. outros filo estina, que ther couragrame,

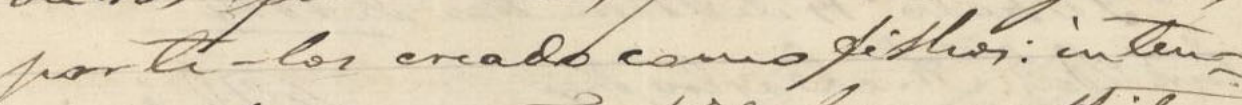

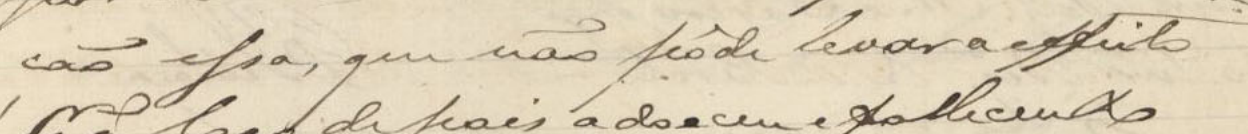

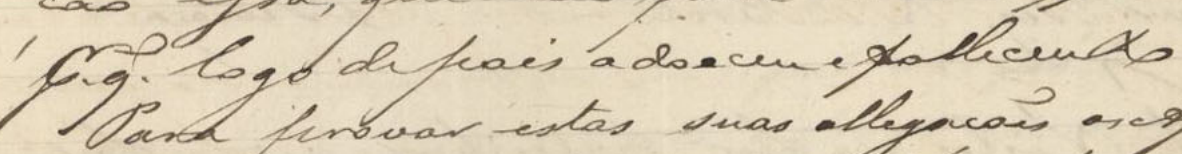

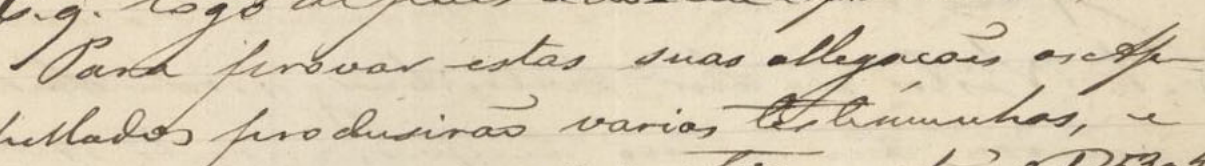
fratados ferodusiras varias limuthas, e

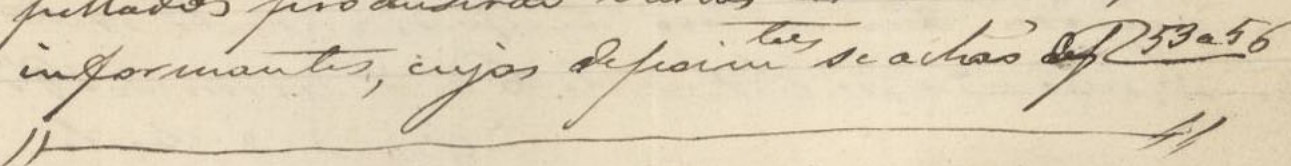


Fólio 91R ${ }^{26}$

Relatorio

Os Autores Appellados depois de obterem do

Juis Municipal do Termo de São Luiz se-

rem postos em deposito, eque se lhes dés-

5 sem Curador, propuseram esta acçaõ

de liberdade, allegando nas petiçoẽs de

folhas 2 e 13 que tinhaõ direito a serem

declarados livres por sentença, porque

sua Senhora Dona Theodora Lima de

10 Toledo dissera por veses, á diferentes

pessoas de conceito, e criterio, que era

sua intençaõ, por sua morte, dei-

xar livres seos escravos: Uns pelos bons

serviços que lhe haviaõ prestado; e

15 outros pela estima, que lhes haviaõ prestado; e

outros pela estima, que lhes consagrava,

por te-los creado como filhos: inten-

çaõ essa que naõ pôde levar a effeito

porque logo depois adoeceu e falleceu.

20 Para provar estas suas allegaçoẽs os Ap-

pellados produsiraõ varias testemunhas, e

informantes, cujos depoimentos se achaõ defolhas 53 a 56 .

${ }^{26}$ Este fólio possui, na parte inicial, anotações de terceiro, que não foram editadas 
DOC 8

143

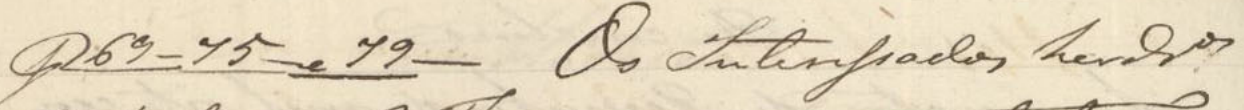

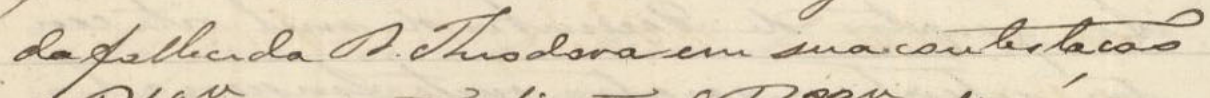
moda una ferchia lem brar be de hber= tor ses escravas, oacreficands seu cre= dito, efereficalicando dear credareg, vito

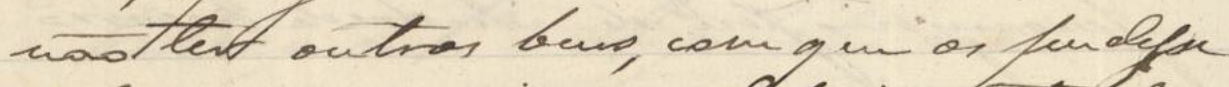

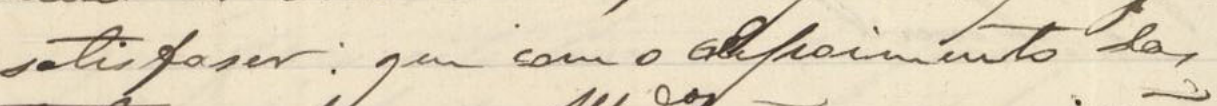

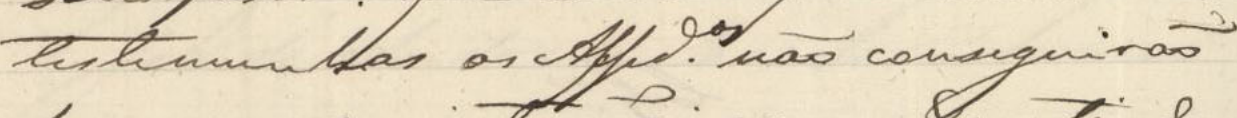
firracer sua intiveas: equ altuvetindo=

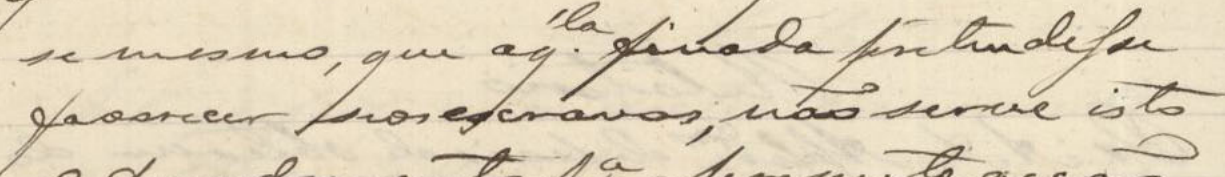
defundan ente for aferemite accas

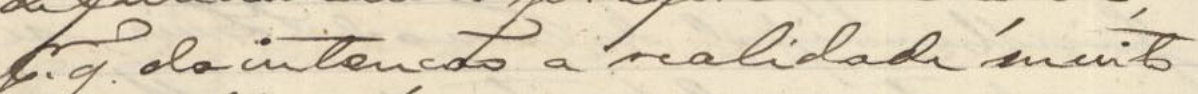
Enta \& Q Hive de Dirite reofuetivo na centurea

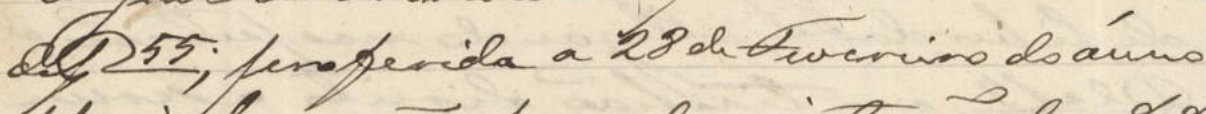

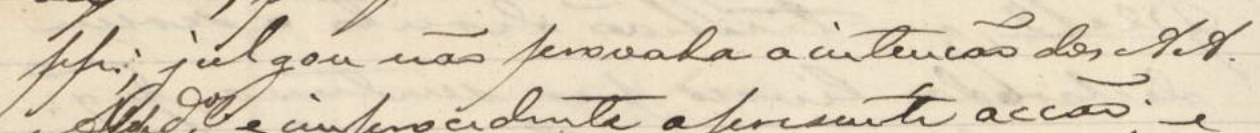

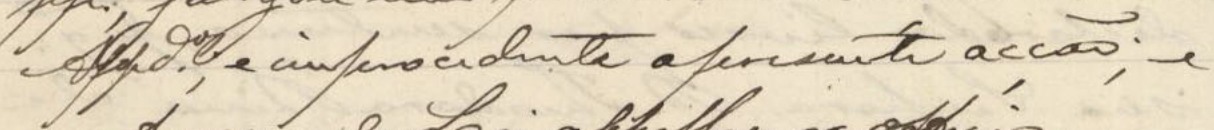

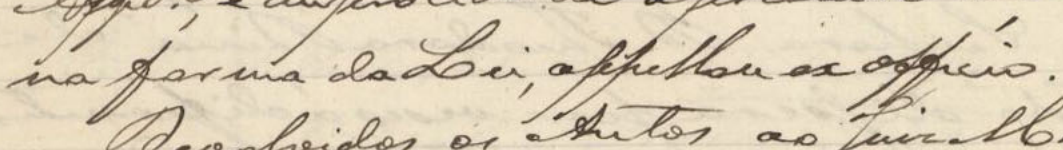

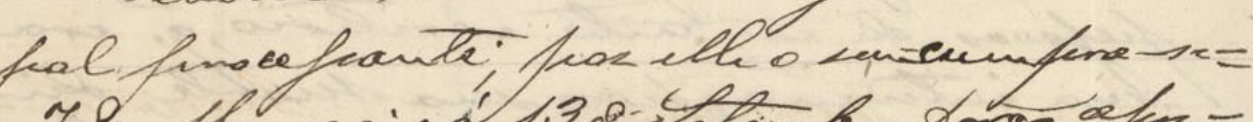

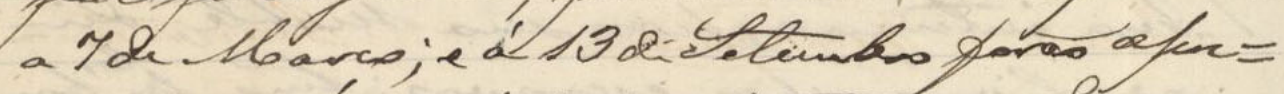

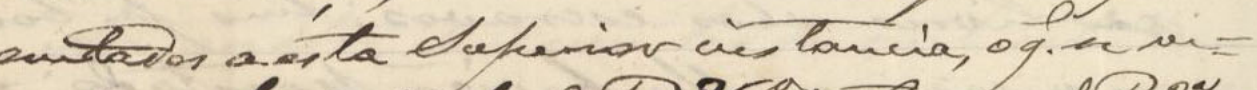

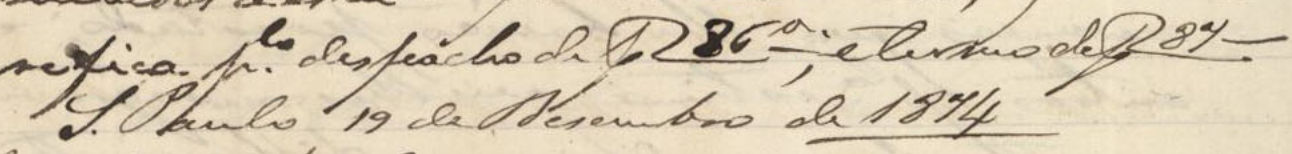

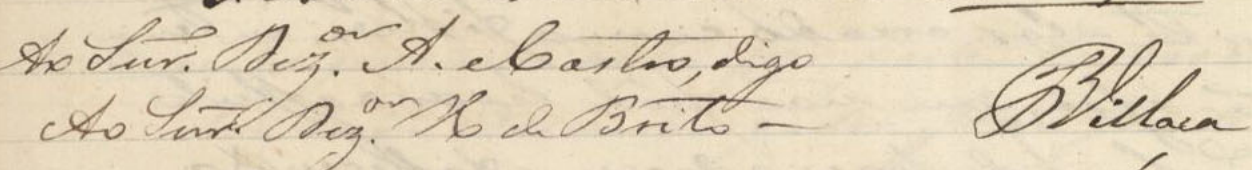

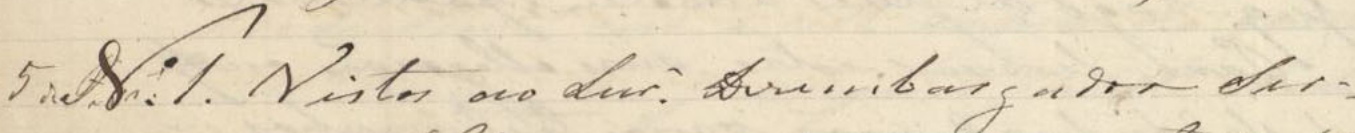

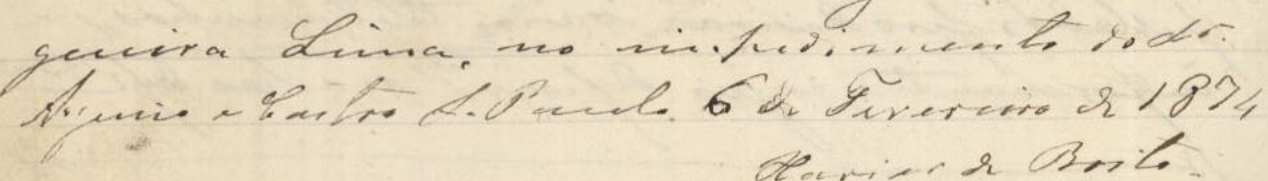


Fólio 91V

folhas69-75- e 79- Os interessados herdeiros

da fallecida Dona Theodora em sua contestaçaõ

defolhas $49 \mathrm{v}$ erso, e rasoẽs finaes defolhas $83 \mathrm{v}$ erso oppoem-se

a pretençaõ dos Appellados allegando, que a dona fi-

5 nada naõ podia lembrar-se de liber-

tar seos escravos, sacrificando seu cre-

dito, e prejudicando seos credores, visto

naõ ter outros bens, com que os pudesse

satisfaser: que com o depoimento das

testemunhas os Appellados naõ conseguiraõ

provar sua intençaõ: eque admetindo-

se mesmo, que aquela finada pretendesse

favorecer seos escravos, naõ serve isto de

fundamento para apresente acçaõ

15

porque da intençaõ a relidade muito

dista.

O Juis de Direito respectivo na sentença

defolhas 55, proferida a 28 de fevereiro do anno

próximo passado; julgou naõ provada a intençaõ dos Autores

20

Appellados; e improcedente a presente acçaõ; e

na forma da Lei, appellou ex officio.

Devolvidos os Autos ao Juis Munici-

pal processante; por elle o seu cumpre-se-

a 7 de Março; e á 13 de Setembro foraõ apre-

sentados a esta Superior instancia, o que se ve-

rifica pelo despacho defolhas $86 \mathrm{v}$ erso; e termo de folhas 87 -

Saõ Paulo 19 de Setembro de 1874.

Ao Senhor Dezembargador Aquino e Castro, digo

Ao Senhor Dezembargador Xavier de Brito - $\quad$ Villaça $^{27}$

${ }^{27}$ Este fólio possui, a seguir, anotações de terceiro, que não foram editadas. 
DOC 8

145

PP

14r. Vies: conformo- mo

wour selatosi. Dade, kewters

dass ys

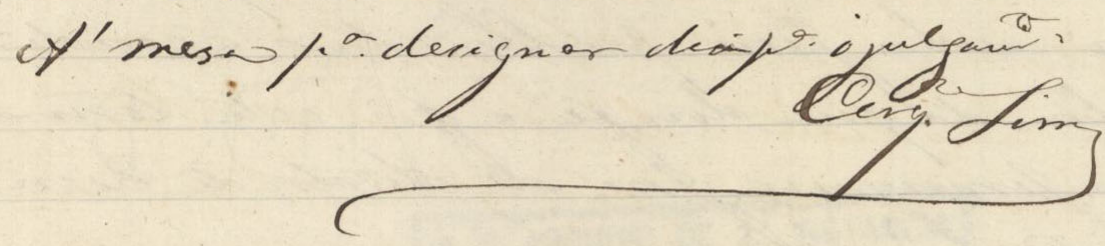

Ode loje. Itank 12 de ter?

de $18 \%$

Wlant

Listos, e relabosos estes tu tos binis

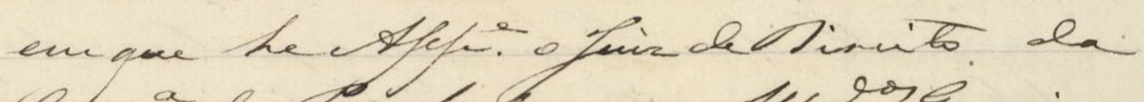

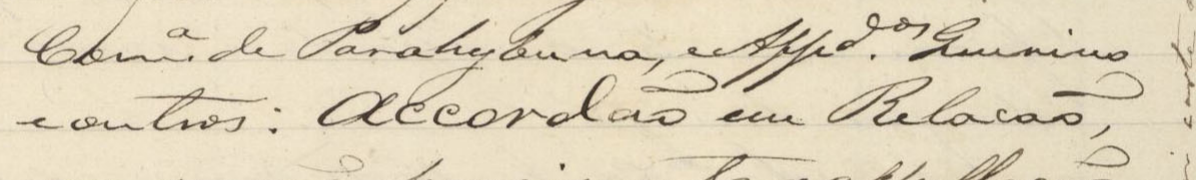

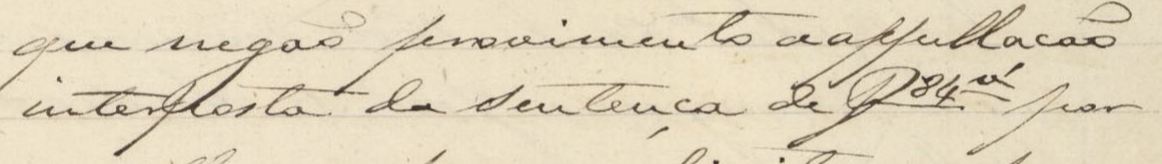

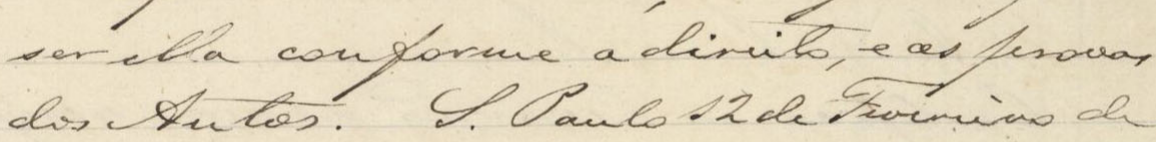

gapt -

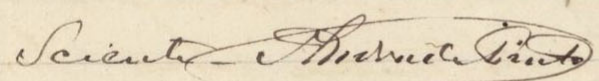

B3allaw

eig. 2lins

Weblecacas

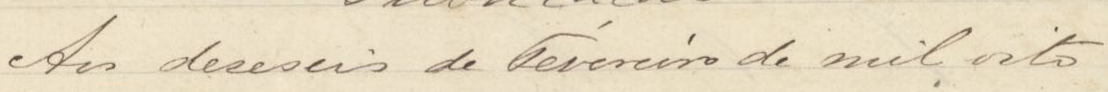

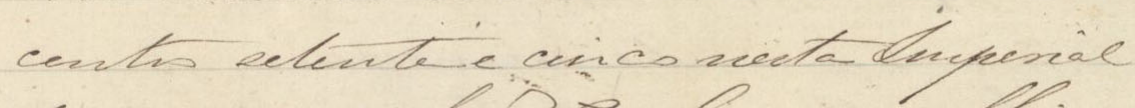

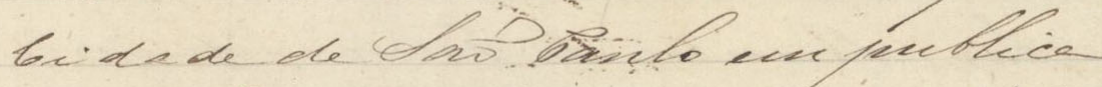

- genal aindiencias que arr peites

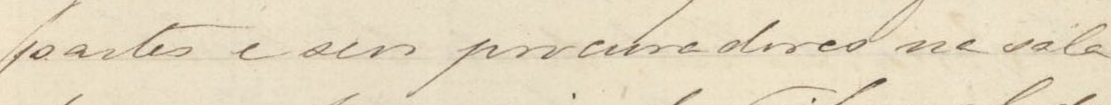
- das enferencià de asibunal da Melacals faundo celaras - fuic 
Fólio 92R 28

Número 141 Vistos: conformo-me

com o relatorio. São Paulo, 12 de Fevereiro

de 1875 .

Á mesa para designar dia para o julgamento.

\section{Cerqueira lima 29}

Vistos, e relatados estes Autos Civeis

em que he Appellante Juis de Direito da

Comarca de Parahybuna, Appellados Guerino

e outros: Accordaõ em Relaçaõ,

que negaõ provimento a appellaçaõ

interposta da sentença de folhas $84 \mathrm{v}$ erso, por

ser ella conforme a direito, e as provas

dos Autos. Saõ Paulo 12 de fevereiro de

15 1875-

\section{(J.A. Santos, P.)}

Villaça

\section{Cerqueira Lima}

Sciente -(Pinto)

Xavier de Brito ${ }^{30}$

28 Este fólio possui na lateral e transversal anotações de terceiro, que não foram editadas.

29 Este fólio possui, a seguir, anotações de terceiro, que não foram editadas.

${ }^{30}$ Este fólio possui, a seguir, anotações de terceiro, que não foram editadas. 


\subsection{DOC 9}

Documento: Sentença

Remetente: juiz ordinário representando a Justiça Estadual de São Paulo - $1^{0}$ grau

Local: Areias

Processo: 144/1874

Juiz: Manoel Rodrigues Jardins

Destinatários:

Autor: Miguel da Naçaõ

Réu: Casemiro dos Santos Pinto

Data: 20 de fevereiro de 1875

Descrição: 4 fólios- páginas 88 verso, 89 recto e verso, 90 recto e verso, anotados por apenas um punho, o próprio juiz proferidor da decisão. Trata-se de uma ação de manutenção de liberdade intentada por um escravo que encontrava-se fugido. Baseia seu pedido na lei de proibição ao tráfico, quando fora importado. O juiz julga nula a ação, nem avaliando o mérito, por entender não ser esta a competente para o pedido que fez o autor - a liberdade. 
DOC 9

148

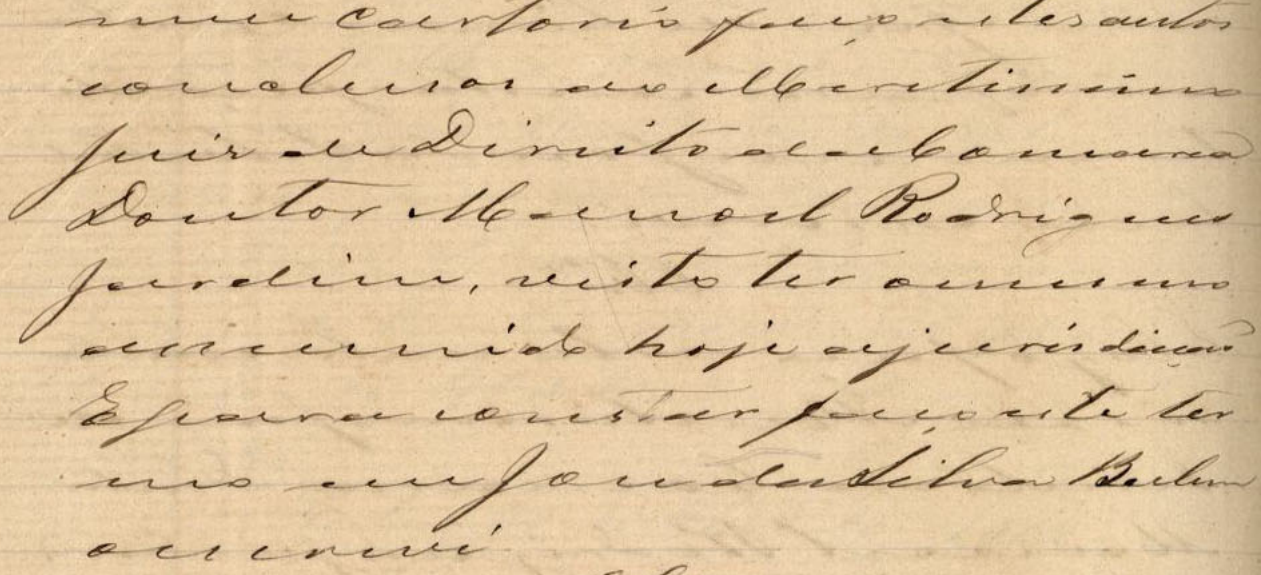

Ciestos estes autos of.

Qpreta alli-

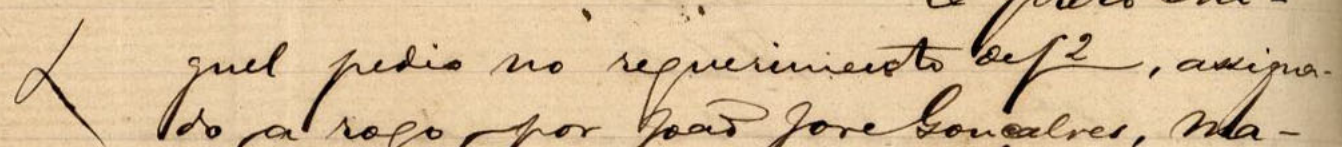

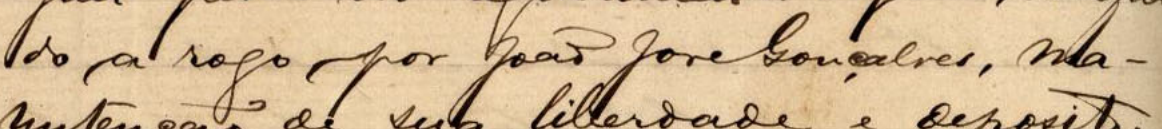
nuteneros de vula lillersade e deporits; a sino depovitas - cantho gu

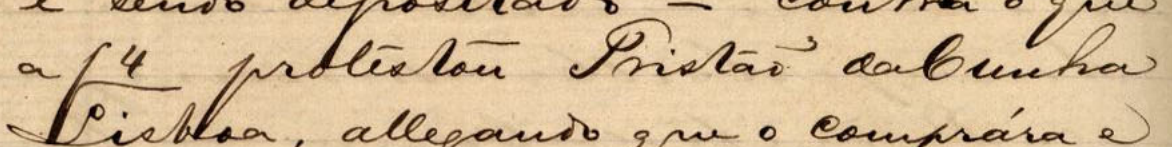
Disblar, allegano gne o couprára e - Foriue como everlaro ha berca de thicle aunos, apsin taumber coutra bonoulves a celjar rugestoes attribue a figare optocedinento de Aliguel dinda for mio do, refirioboucalves pedio nonaminte af6 aguella mafuteñow e a nomeacas de un Eurator para, cou intimacal do teuhor, deffecuder os tea déreitos, - a $\frac{20}{20}$ a jus hificaras de ver

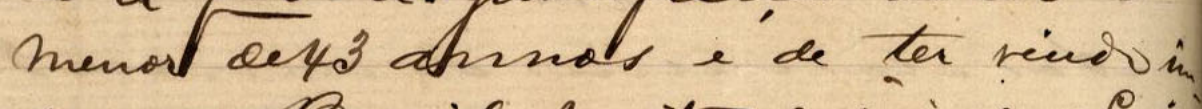
postar para o Prajil muit apsir da Dei

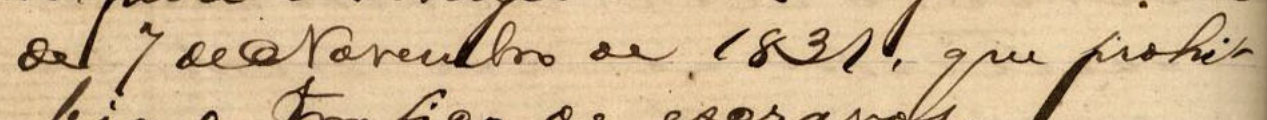
bio Hafico de exaravols. 
Fólio $88 \mathrm{~V} 31$

Vistos estes autos (ilegível) O preto Mi-

guel pedio no requerimento defolhas 2 , assigna-

do a rogo por Joaõ José Gonçalves, ma-

nutençaõ de sua liberdade e deposito;

5 e sendo depositado - contra o que

a folhas 4 protestou Tristaõ da Cunha

Lisboa, allegando que o comprára e

o possue como escravo ha cerca de

vinte annos, assim tambem contra

10 Gonçalves a cujas sugestoẽs attribue

a fuga e o procedimento de Miguel -

ainda por meio do referido Gon-

çalves pedio novamente afolhas 6 aquel-

la manutençaõ e a nomeaçaõ de

15 um Curador para, com intimaçaõ

do Senhor, defender os seos direitos,

e a folhas 20 a justificaçaõ de ser

menor de 43 annos e de ter vindo im-

portado para o Brasil muito depois da Lei

20 de 7 de Novembro de 1831, que prohi-

bio o trafico de escravos.

${ }^{31}$ Este fólio possui, em sua parte inicial, anotações de terceiro, que não foram editadas. 


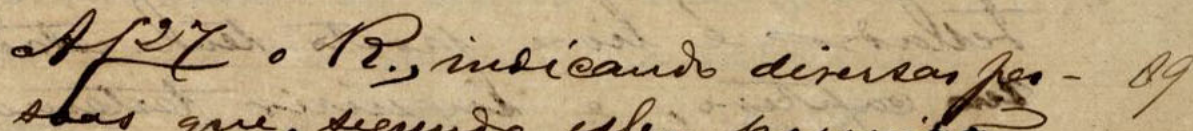

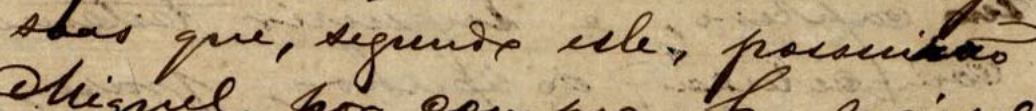
Aliguel, foor ooupira, Ha mair de thintar amsos if ie aclegans tel -

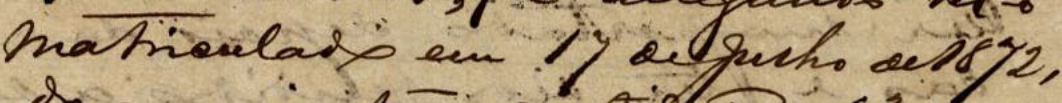

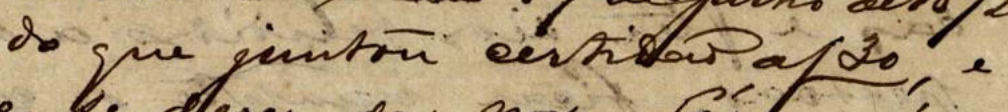
- Le ferer dar nosa forina ás

is qurotser de libusade posberiormente á Sei de 28 de detron bro de 1831 - repunusfay $28 n)$ a cetlinaras do kiposteb en que extaina Nigfeel a a enthezar Deste; refpuriments que

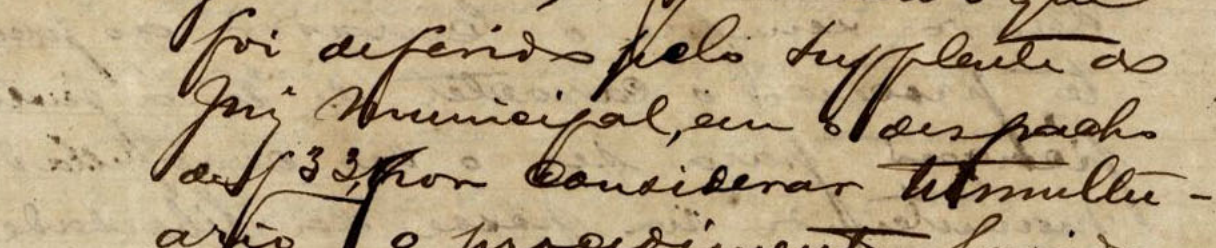

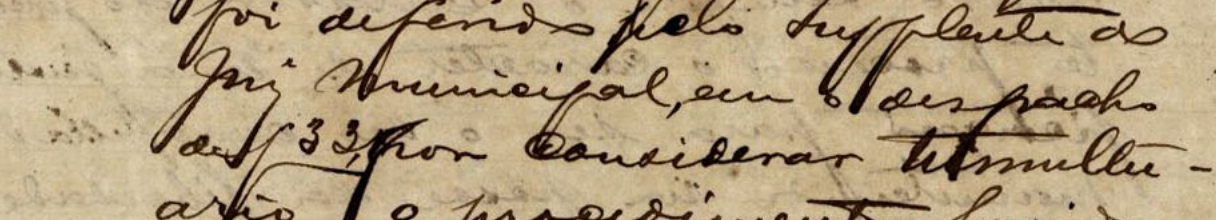
atio 10 firsocinents harist, e nas kichin nem prexcunpeas de Len 0 A. Afpicho linte!

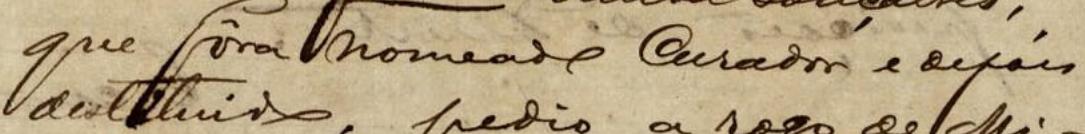
dectlivise, frebis a rogo delduisul a nonfeario or fen ocetso Oceross jacia:

iida m in pequer - feila icutifidaras;

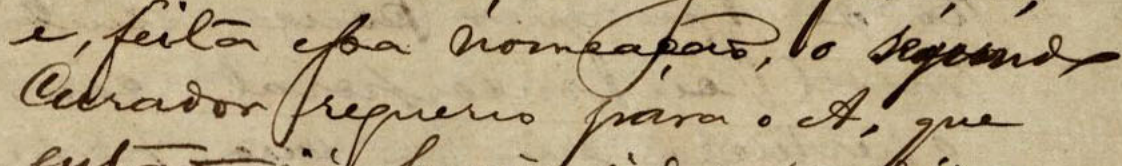
eulajoil haria dide reuldids a visff fiefaia, norode-

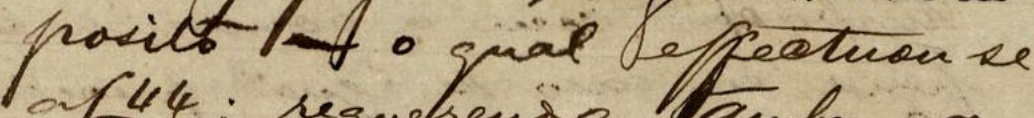
ar 44 ; requatrenis lambar a 148 prfinar hos meio da acowo de manutenised gue bes cura- 
Fólio 89R

Afolhas 27 o Réu, indicando diversas pessoas que, segundo elle, possuiraõ Miguel, por compra, ha mais de trinta annos, e allegando tel-o

5 matriculado em 17 de julho de 1872, do que juntou certidaõ afolhas 30 , e e se dever dar nova fórma ás questoẽs de liberdade posteriormente á Lei de 28 de Setembro de 1871 - requereo (afolhas $28 \mathrm{v}$ ) a extinç̧aõ do deposito em que estava Miguel e a entre ga d'este; requerimento que foi deferido pelo Supplente do

15 Juiz Municipal, em despacho de folhas 33, por considerar tumultuario o procedimento havido, e naõ existir nem presumpçaõ de ser o Autor Africano livre.

Afolhas35 ainda Gonçalves, que fôra nomeado Curador e depois destituido, pedio a rogo de $\mathrm{Mi}$ guel a nomeaçaõ de um outro Curador para promover as requeridas manutençaõ e justificaçaõ; e, feita essa nomeaçaõ, o segundo Curador requereo para o Autor, que entaõ já havia sido vendido a outra pessoa, novo deposito o qual effectuou-se afolhas 44; requerendo tambem a folhas 48 provar por meio da accaõ de manutençaõ que o seo Cura- 
DOC 9

152

tellas é liove posto lenta etaxs cono caftiro, a Liquirir testemunhas, Oom citarew do ofuhor, prava, juictipicuro Rei elle menon bee \&plannos, Vir inforthes depan da Leicitá. dar i ter sio nelivise a direras pervovis fiear iecuptes or eaptiveiro

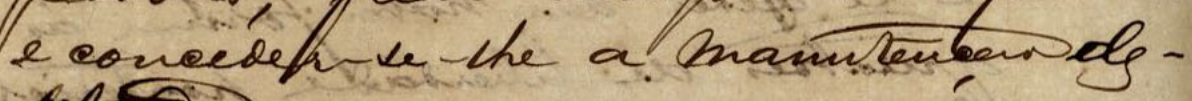
fibloade-

Finalmente - def $\$ 4 \mathrm{~cm}$ diant Frnos ingrividas ar testemunhar so tre efoel hey pontrs, cour audieir-

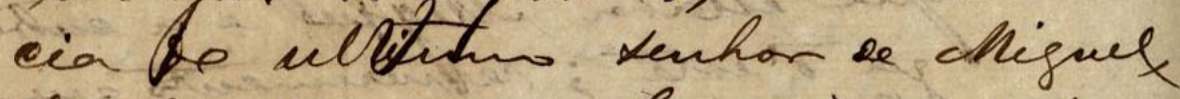
danib venfrie o leurator ao preente proverdo caracter de ema jurti. Fiengent para ser o reo curaftellavo - manuterfios na prose ba liberdady.

Qque his hem regaminat, e ristor be tesmosio da ach e virprovicat de bireits:

Gooudide -

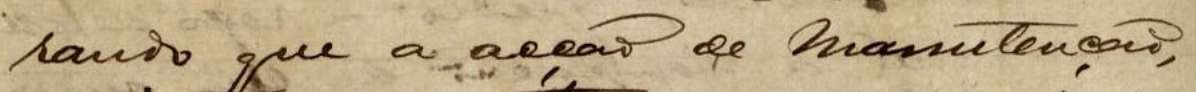
on inffitoi rétinens proskessionis,

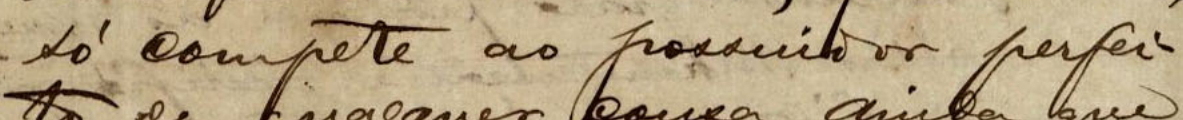
To de fraequer boura, airba pus horel ou incorfiosal, cantta guem - pertivilea un a sua pofae, febin. Do-de for exla a detridtencéa der

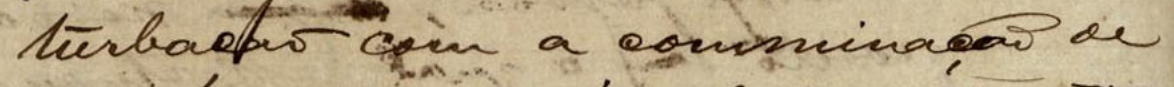
Fena en caso de ifual quacéienents

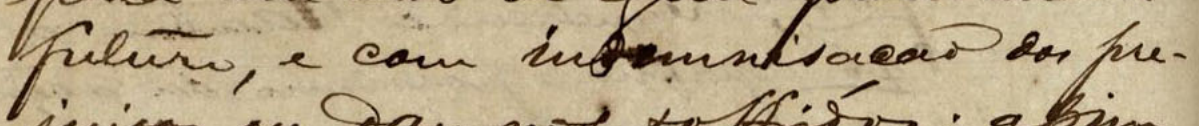
juviser on daunsos tofsitos; apsin 
Fólio 89V

telado é livre posto tenha estado como captivo, e inquirir testemunhas, com citaçaõ do Senhor, para, justificado ser elle menor de 40 annos,

5 ser importado depois da Lei citadas e ter sido vendido a diversas pessoas, ficar isempto do captiveiro e conceder-se-lhe a manutençaõ de liberdade-

Finalmente - defolhas54 em diante foraõ inquiridas as testemunhas sobre esses trez pontos, com audiencia do ultimo Senhor de Miguel, dando sempre o Curador ao presente processo o caracter de uma justificaçaõ para ser o seo curatelado manutenido na posse da liberdade.

$\mathrm{O}$ que tudo bem examinado, e vistos os termos dos autos e disposiçoẽs de direito:

\section{E conside-}

rando que a acçaõ de manutençaõ, ou interdicto retinendos possessionis, só compete ao possuidor perfeito de qualquer cousa, ainda que movel ou incorporal, contra quem o perturba em a sua posse, pedindo-se por ella a desistencia da turbaçaõ com a comminaçaõ de 30 pena em caso de igual procedimento futuro, e com indennisaçaõ dos prejuisos ou dannos soffridos; assim 
DOC 9

154

como one tal aceas dere der fro pouth dentro de aino e dia tpara ver acila e carreren summariamente ar sea teminar- Li l? in prime. e 59 Bij. uli pavio, Os? lir. 3. hit 48 e hit 3850 , Concolir? dar leir cir. not 2 as ast. \& 12 , Conía Peles-doutr.dar ace. 55190 a 192 e rexpentinas nober aijents

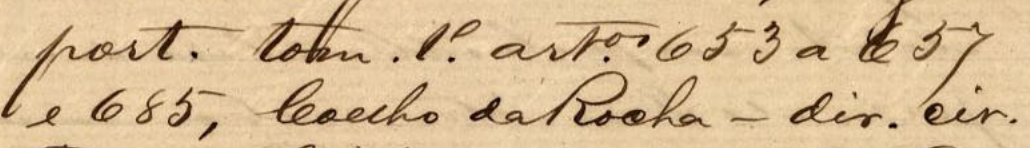

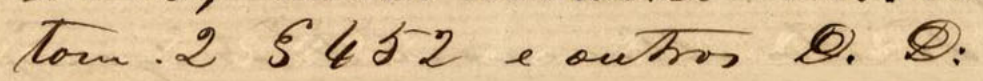

Consideranto que pelo depoimento dar lestementiar pelat propinas

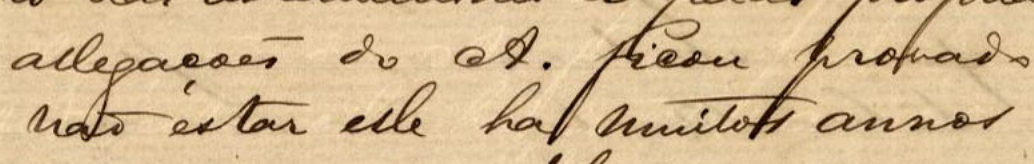
na pope de vera liberdade, mat sif fomo eaptino até 15 an lle octehereivo alls I/, - data en giu figis da cava ort?. 'e rela plimbina tey

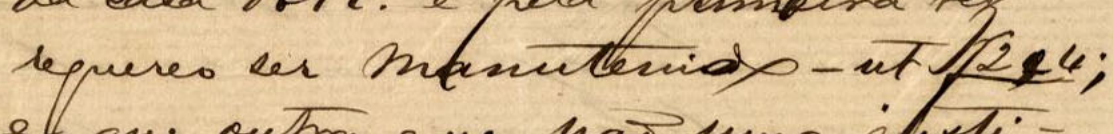
ef gue outra, gue nas uma juxtifienear comb a presente afjo meriló nat te fóde agorabauciar, teria e é a aceas compettulé pa ra 08. Len délarasolliure- learforme pede nolocuasor: quepo mello frexente procexta - Frela ihcounfrañar do meis i areats ufata, alem dak irregularibabes gue ke deras a de diourem fo relatisio ou ex- 
Fólio 90R

como que tal acçaõ deve ser proposta dentro de anno e dia para ser aceita e correrem summariamente os seos termos - Lei $1^{\text {a }}$

5 in prime. e $\S 9$ Digesto inti possio, Ordenamento Livro 3 titulo 48 e titulo $78 \S 5$, Consolid ação das leis civis nota 2 ao artigo 812, Corrêa Telles - doutrina das (accão) $\S \S 190$

a 192 e respectivas notas, Digesto

10 (ilegível) tomo $1^{\mathrm{O}}$ artigos 653 a 657

e 685, Coelho da Rocha - direito civil

tomo $2 \S 452$ e outros (D.) (D):

Considerando que pelo depoimen-

to das testemunhas e pelas proprias

15

allegaçoẽs do Autor ficou provado

naõ estar elle ha muitos annos

na posse de sua liberdade, mas

sim como captivo até 15 ou 16 de Fe-

vereiro de 1874, data em que fugio

20

da casa do Réu e pela primeira vez

requereo ser manutenido - intimação folhas 2 e 4;

e que outra, que naõ uma justi-

ficaçaõ como a presente cujo me-

rito naõ se pode agora apreciar,

seria e é a acçaõ competente pa-

ra o Autor ser declarado livre - con-

forme pede o seo Curador:

Julgo nullo o presente processo

pela incompetencia do meio

30 e acçaõ usada, alem das

irregularidades que se deraõ

e se dedusem do relatorio ou ex- 


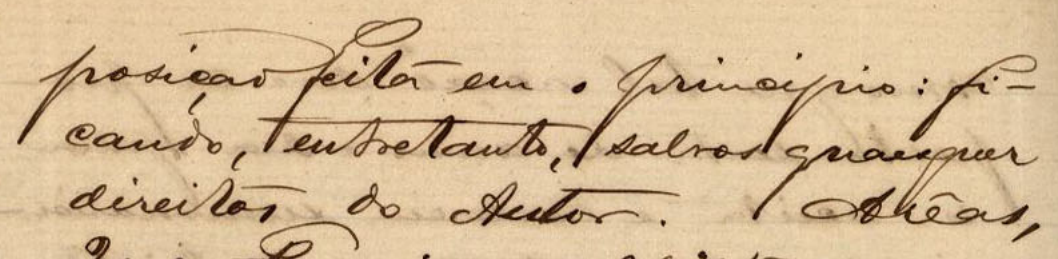
DodetPrereiro allog S Planoel Torigues farbiu

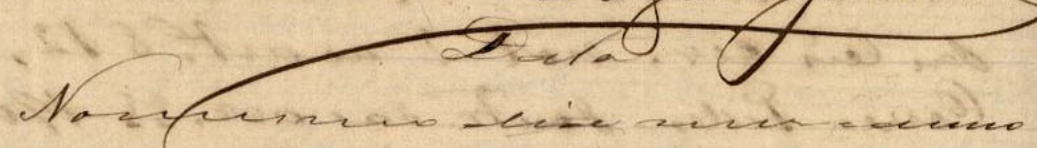

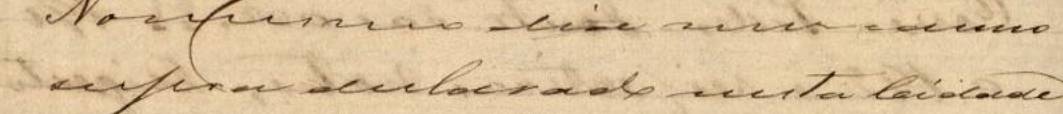

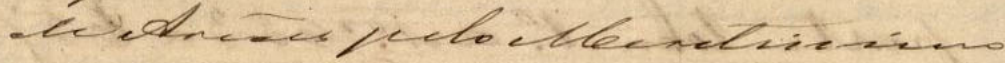

facir ceden ib-c-eba

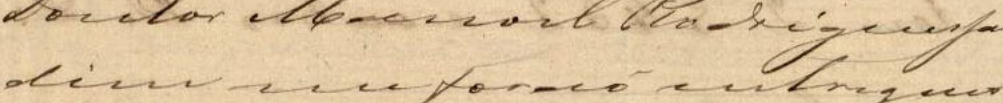

atesocetos a

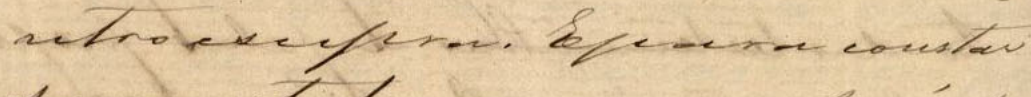

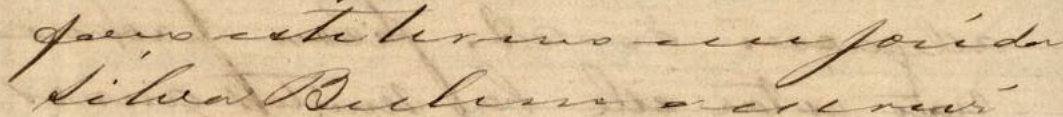

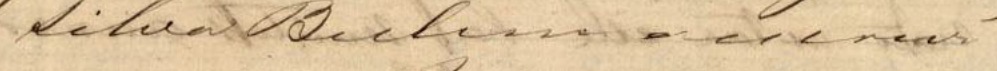

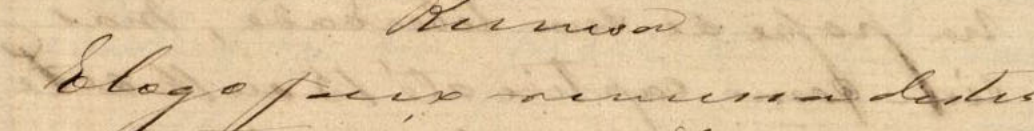

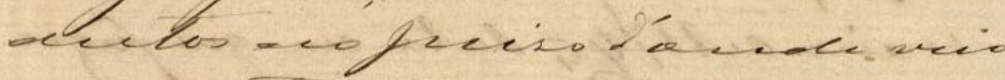

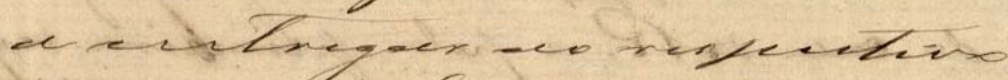

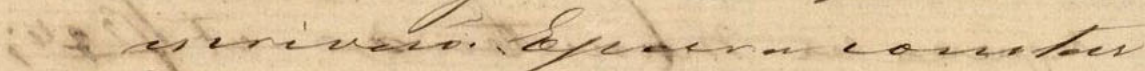

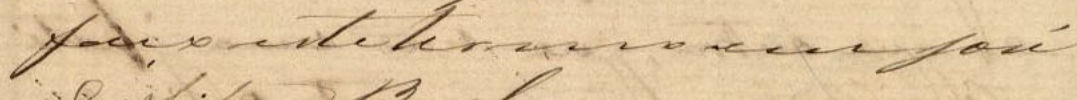

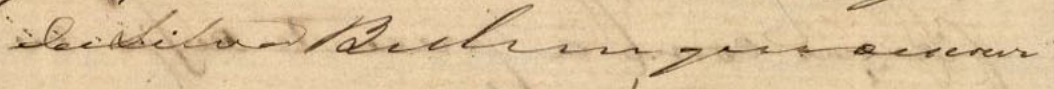

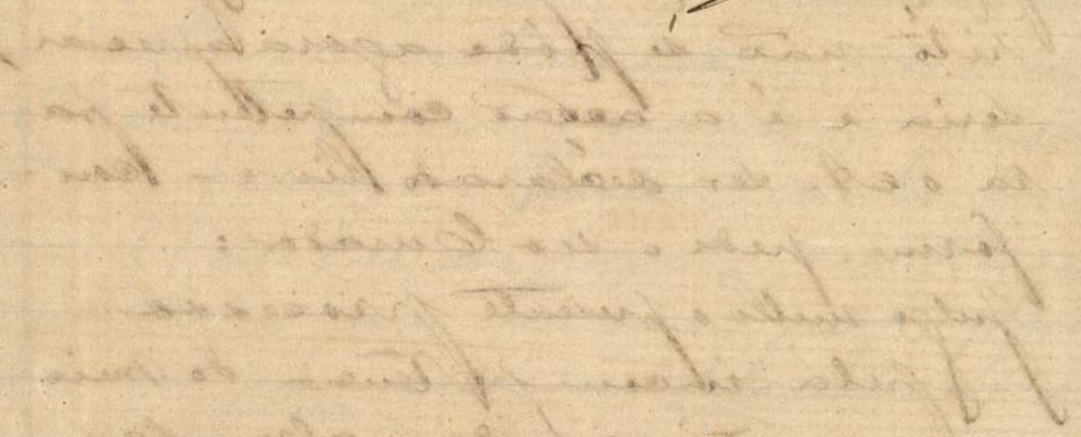


Fólio 90V

posiçaõ feita em o principio: fi-

cando, entretanto, salvos quaisquer

direitos do Autor. Arêas,

20 de fevereiro de 1875 .

5 Manoel Rodrigues Jardim ${ }^{32}$

32 Este fólio possui, a seguir, anotações de terceiro, que não foram editadas. 


\subsection{DOC 10}

Documento: Acórdão (relatório e decisão)

Remetentes: juízes desembargadores representando a Justiça Estadual São Paulo - Tribunal da Relação $-2^{\mathrm{O}}$ grau

Local: São Paulo

Processo: $144 / 1874$

Destinatários:

Apelante- Juiz ex officio pelo Autor: Miguel da Naçaõ

Apelado: Casemiro dos Santos Pinto

Data: 01 de fevereiro de 1876

Desembargador Relator: Antonio Candido da Rocha (responsável pelo Relatório)

Descrição: 6 fólios- páginas 115 verso, 116 recto e verso, 117 recto e verso, 118 recto, sendo o relatório de um só punho, os votos pelos punhos dos respectivos desembargadores responsáveis, e a decisão pelo punho do desembargador Ignácio José de Mendonça Uchôa, confirmada pelos demais desembargadores. Trata-se de uma ação de manutenção de liberdade intentada por um escravo que encontrava-se fugido. Baseia seu pedido na lei de proibição ao tráfico, quando fora importado. O juiz julga nula a ação, nem avaliando o mérito, por entender não ser esta a competente para o pedido que fez o autor - a liberdade. O juizo apela ex officio e o Tribunal confirma a decisaõ de $1^{\mathrm{O}}$ grau. 
dectaredrs, pets Deceivbangedir ba dor extes dintes cen o seo deysecho se tro ofeer publecer en mintre nas e revelia das partes do que dre fe

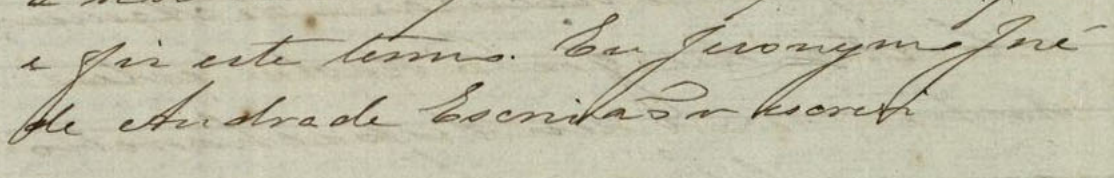

$$
\text { Se enschera }
$$

Ao ties de Denenbro de nil wit

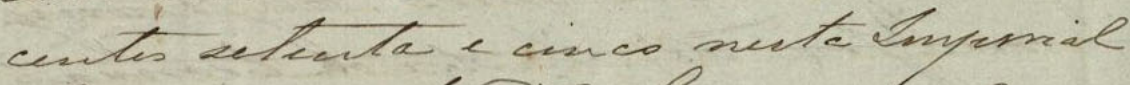

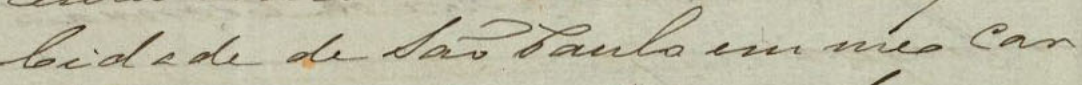
tris facs ectes autes enchur as Quenbargadin ofutorio bandids de butha, dogue face cete teme ba feconymo the de oftes drade Spervioff a eberui:

$$
\text { bofor }
$$

\section{a). $4 y$}

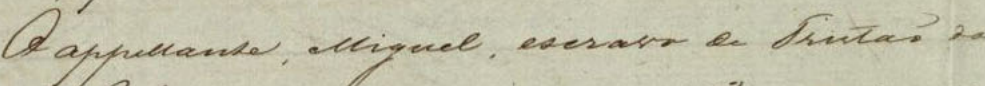

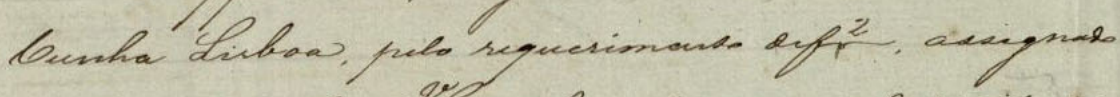

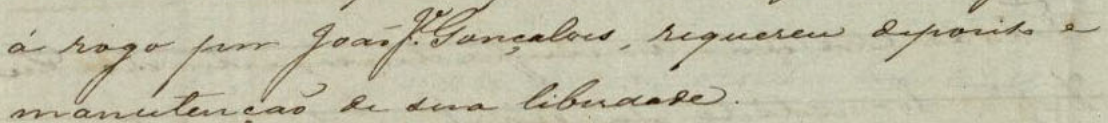

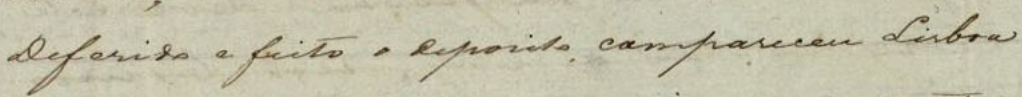

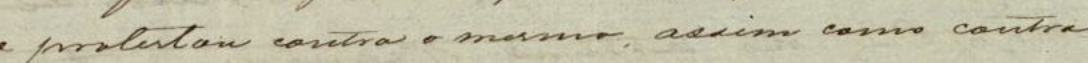
Aancalues allyanse que camprara a Mignel

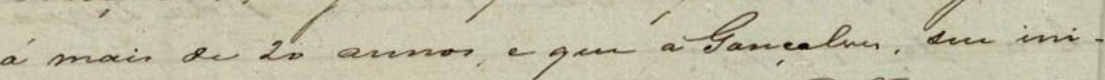

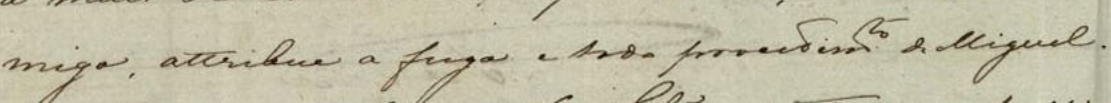

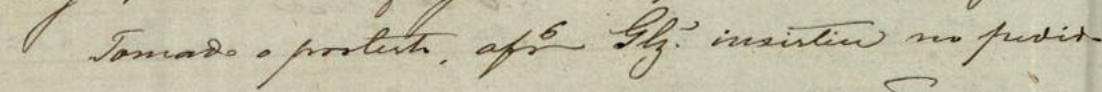

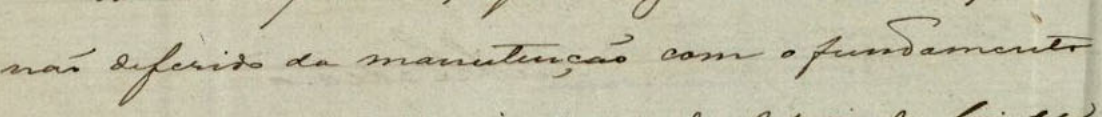

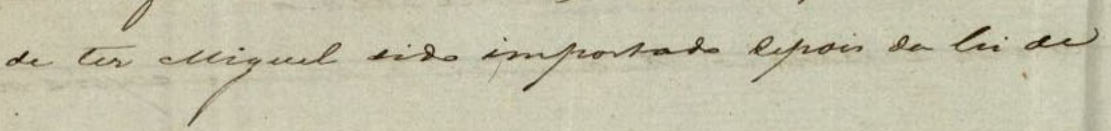


Fólio 115V 33

Número 47

O appellante, Miguel, escravo de Tristaõ

da Cunha Lisboa, pelo requerimento defolhas 2 , assignado

á rogo por Joaõ Jose Gonçalves, requereu deposito e

5 manutençaõ de sua liberdade.

Deferido e feito o deposito, compareceu Lisboa

e protestou contra o mesmo, assim como contra

Gonçalves allegando que comprara o Miguel

á mais de 20 annos, e que a Gonçalves, seu ini-

migo, attribue a fuga e todo prossedimento de Miguel.

Tomado o protesto, afolhas6, Gonçalves insistiu no pedido

naõ deferido da manutençaõ com o fundamento

de ter Miguel sido importado depois da lei de

${ }^{33}$ Este fólio possui, em sua parte inicial, anotações de terceiro, que não foram editadas. 


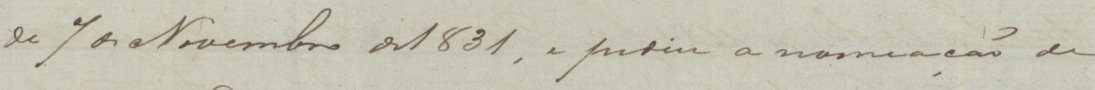
um cusalor.

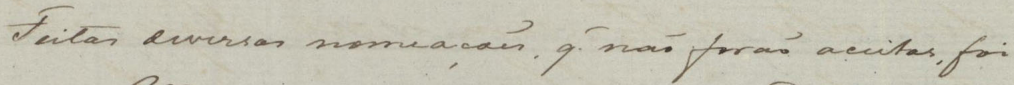

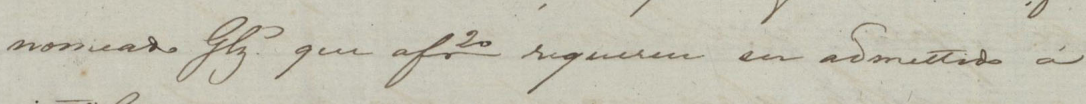
juntificar que Mijuel era menur on 43 amos. E fón impoitado ms depais ea frophibican do trafico, mas, desto decticuse esse munus fulas

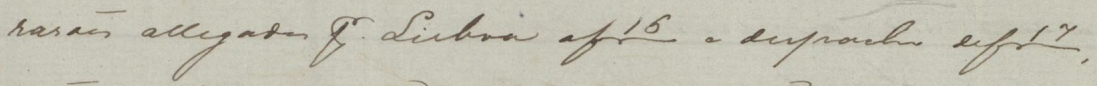

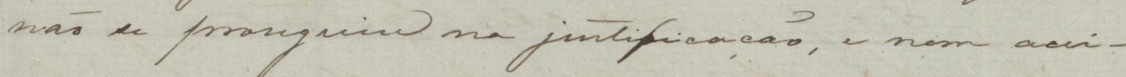

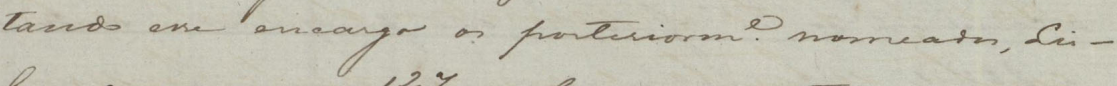

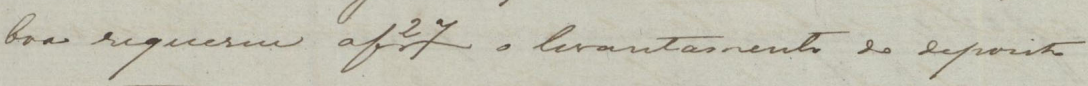

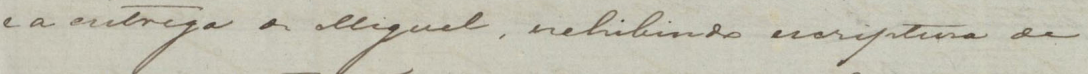
compra e cutibat en mabicula, ryfirind nmes on individew gee a mais a 30 ain, alen

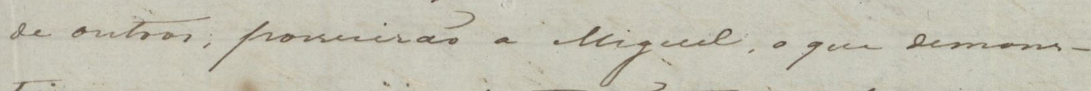

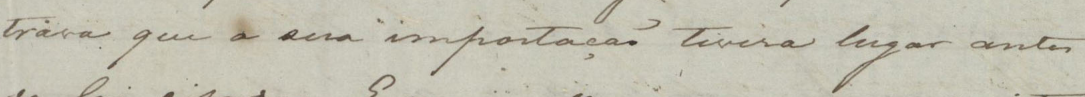
da lis cistata. Smacis elepoin yeu ar oyparta

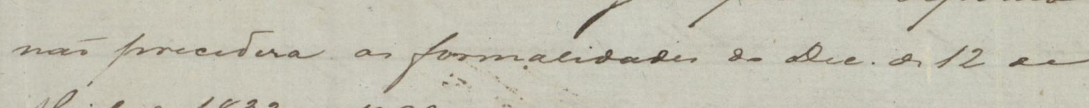

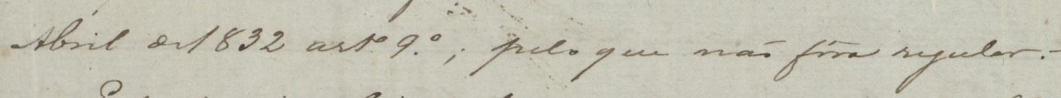

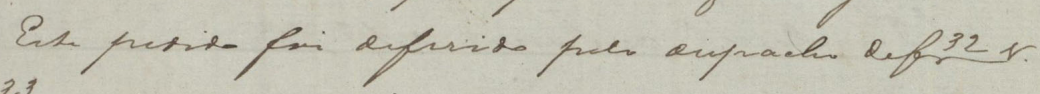

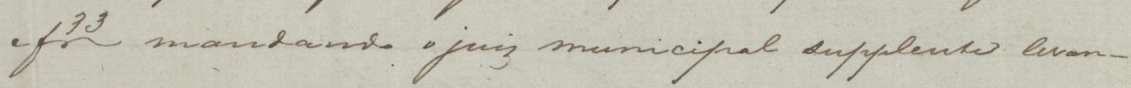

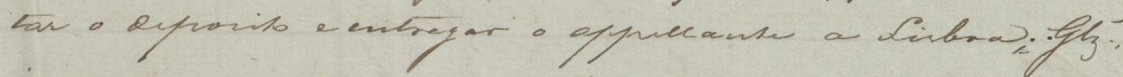

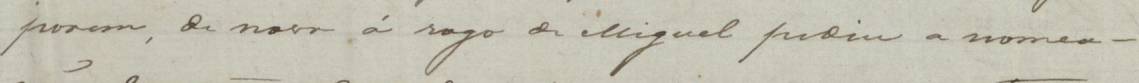

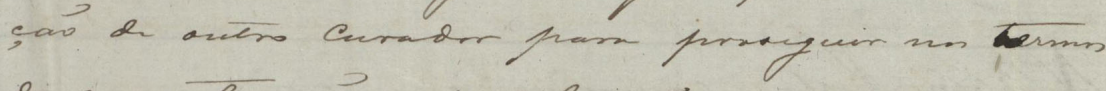

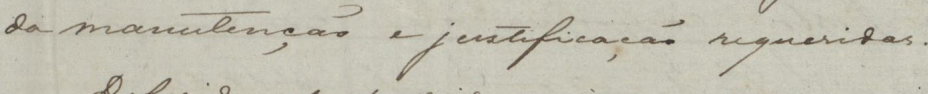

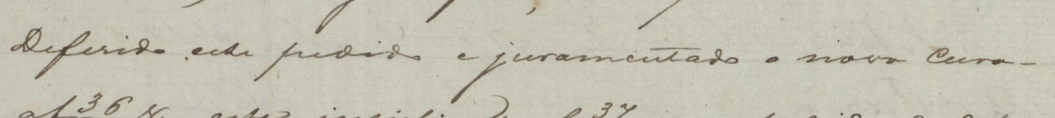

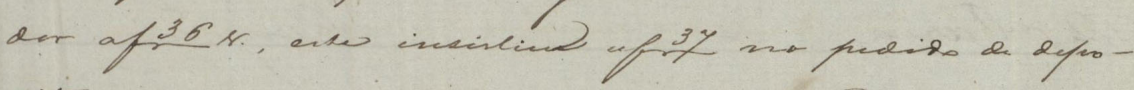

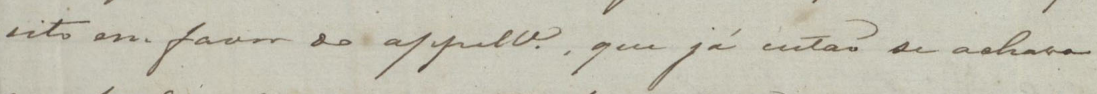
en frover or un aidr frasuidor.

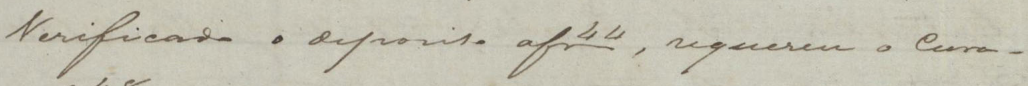

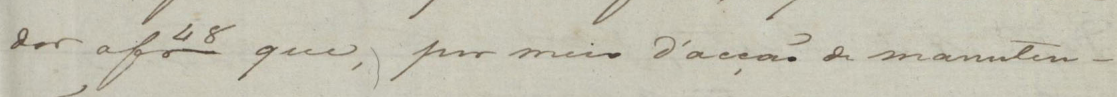

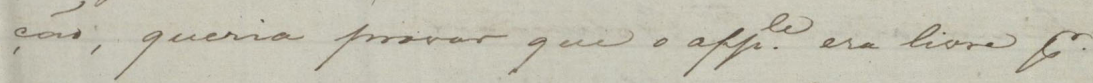

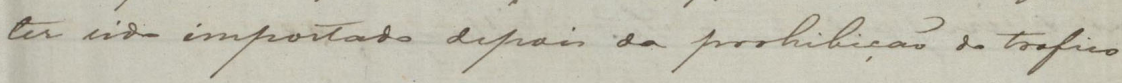


Fólio 116R

de 7 de Novembro de 1831, e pediu a nomeaçaõ de um curador.

Feitas diversas nomeaçoẽs que naõ foraõ aceitas, foi nomeado Gonçalves que afolhas 20 requereu ser admittido á

5 justificar que Miguel era menor de 43 annos, e fôra importado muito depois da prohibiçaõ do trafico; mas, sendo destituido desse mumus pelas rasoẽs allegadas, por Lisboa afolhas16 e despacho defolhas 17, naõ se prosseguiu na justificaçaõ, e nem aceitando esse encargo os posteriormente nomeados, Lisboa requereu afolhas 27 o levantamento do deposito e a entrega de Miguel, exhibindo escriptura de compra e certidaõ de matricula, referindo nomes e individuos que a mais de 30 annos, alem de outros, possuiraõ a Miguel, o que demonstrava que sua importaçaõ tivera lugar antes da lei citada. E mais allegou que ao deposito naõ precedera as formalidades do Decreto de 12 de Abril de 1832 artigo $9^{\circ}$, pelo que naõ fôra regular.Este pedido foi deferido pelo despacho defolhas $32 \mathrm{v} e r s o$ e folhas33 mandando o juiz municipal supplente levantar o deposito e entregar o appellante a Lisboa. Gonçalves, porem, de novo á rogo de Miguel pediu a nomeaçaõ de outro Curador para prosseguir nos termos da manutençaõ e justificaçaõ requeridas.

Deferido este pedido e juramentado o novo Curador afolhas36verso, este insistiu afolhas 37 no pedido de deposito em favor do appellante, que já entaõ se achava em poder de um outro possuidor.

Verificando o deposito afolhas44, requereu o Curador afolhas 48 que, por meio da acçaõ d' manutençaõ, queria provar que o appelante era livre por ter sido importado depois da prohibiçaõ do trafico 


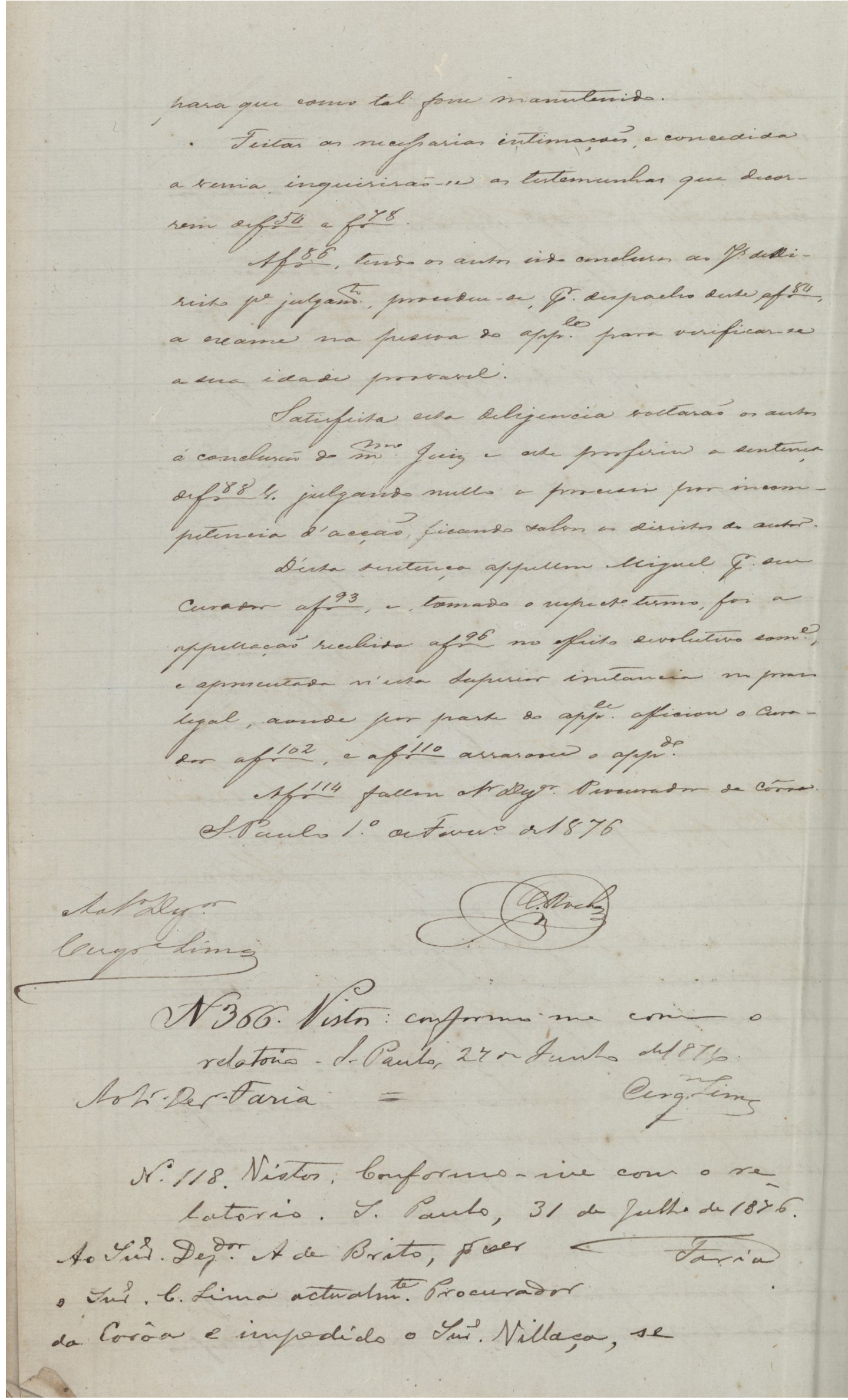


Fólio 116V

para que como tal fosse manutenido.

Feitas as necessarias intimaçoẽs e concedida

a venia, inquiriraõ-se as testemunhas que decor-

rem defolhas 54 a folhas 78.

5 Afolhas86, tendo os autos sido conclusos ao Juis deDi-

reito para julgamento, procedeu-se, com despacho deste afolhas 84 ,

a exame na pessoa do appelante para verificar-se

a sua idade provavel.

Satisfeita esta diligencia voltaraõ o autos

á conclusaõ do Meretíssimo Juiz e este proferiu a sentença

defolhas $88 \mathrm{v}$ erso julgando nullo o processo por incom-

petencia d' acçaõ, ficando salvos os direitos do autor.

Desta sentença appellou Miguel por seu

Curador afolhas93, e, tomado o respectivo termo, foi a

appellaçaõ recebida afolhas 96 no effeito devolutivo somente,

e apresentada n'esta Superior instancia no prazo

legal, aonde por parte do appellante officiou o Cura-

dor afolhas102, e folhas110 arrasoou o appellado.

Afolhas114 fallou Senhor Dezembargador Procurador da Côroa.

20 Saõ Paulo $1^{0}$ deFevereiro de 1876.

Antonio Candido da Rocha Ao Senhor Dezembargador Cerqueira Lima

Número 366. Vistos: conformo-me com o relatorio. Saõ Paulo, 27 de Junho de 1876.

Ao Senhor Desembargador Faria Cerqueira Lima

Número 118 Vistos: Conformo-me com o re-

latorio. Saõ Paulo, 31 de julho de 1876.

Ao Senhor Dezembargador A de Brito, (ilegível) Faria

o Senhor C. Lima actualmente Procurador

30 da Corôa e impedido o Senhor Villaça, se 
DOC 10

165

se assin for determinado jula fireza.

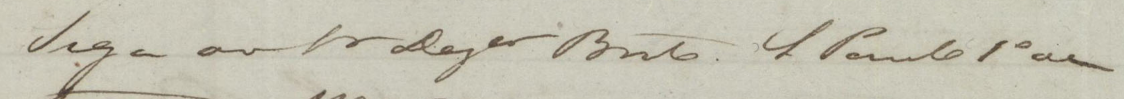

tevar acher

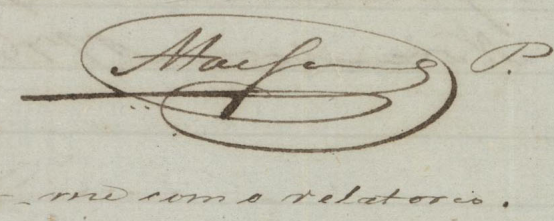

Tister, nonform

IIY

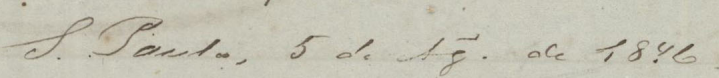

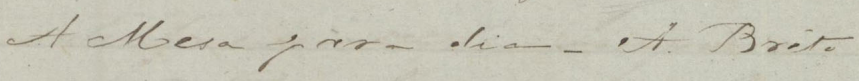

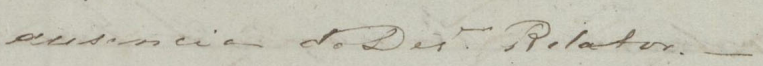

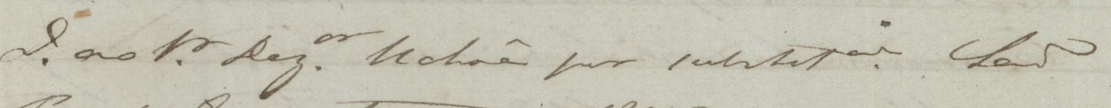

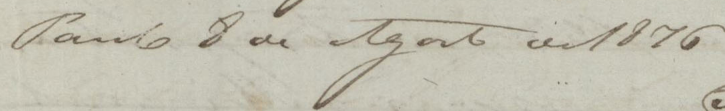

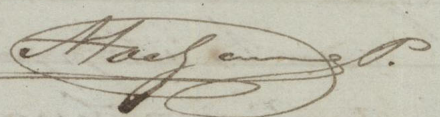

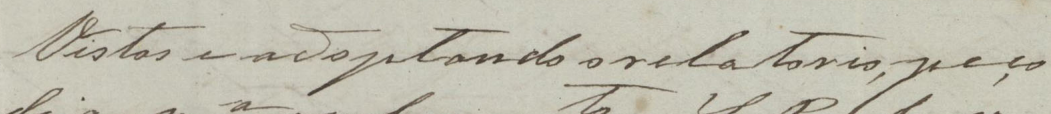

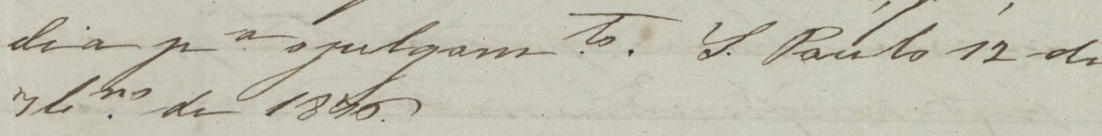

Clesis Celáón.

Lega ar anir de discib an ze has

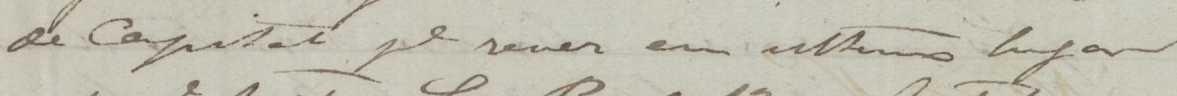

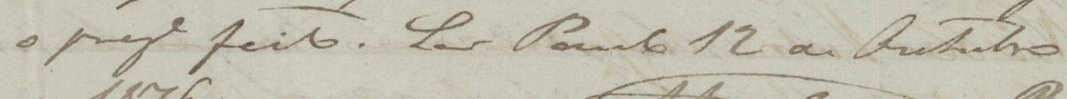
ass?6

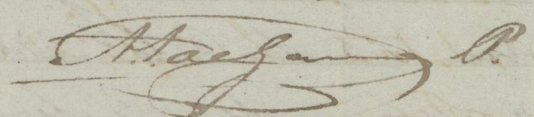

Anve casato ounfuctem? do

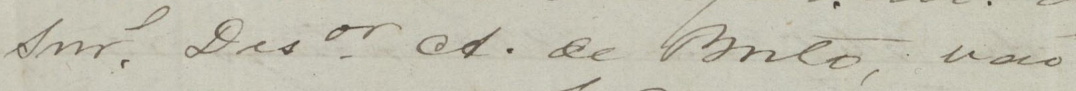
$o$ antar no thr. Der Y elehua. Hounc 3 de elcut det fro.

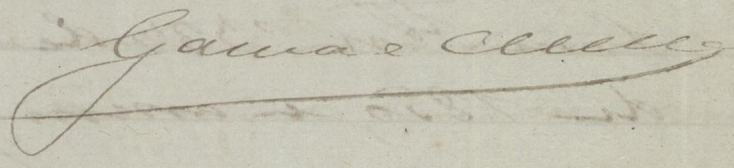


Fólio 117R

se assim fôr determinado

pela Meza. ${ }^{34}$

Vistos, conformo-me com o relatorio.

5 Saõ Paulo, 5 de Agosto de 1876.

A Mesa para dia. - Antonio Brito

ou providenciarem na

ausencia do Desembargador Relator. ${ }^{35}$ Vistos e adaptando o adoptando o relatorio, peço dia para o julgamento. Saõ Paulo 12 de setembro de 1876. Mendonça Û́choa ${ }^{36}$

34 Este fólio possui, a seguir, anotações de terceiro, que não foram editadas.

35 Este fólio possui, a seguir, anotações de terceiro, que não foram editadas.

36 Este fólio possui, a seguir, anotações de terceiro, que não foram editadas. 
DOC 10

167

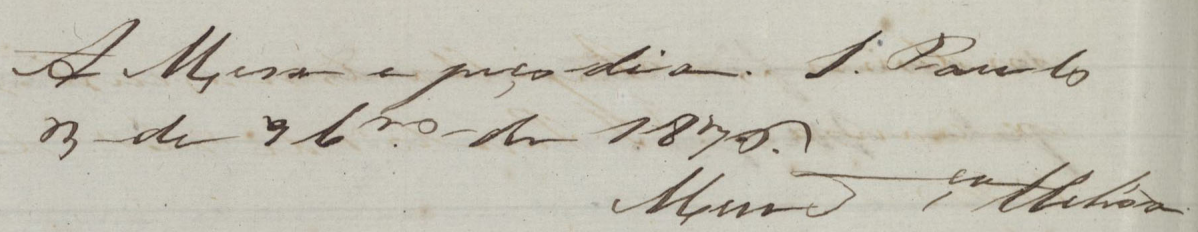

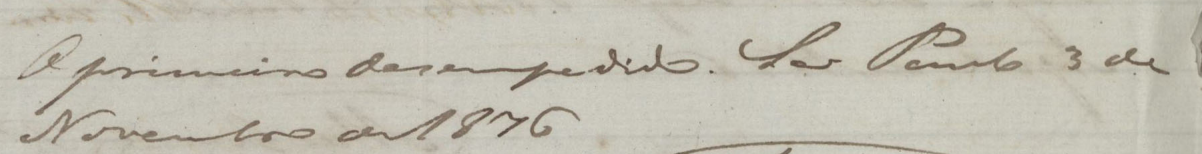

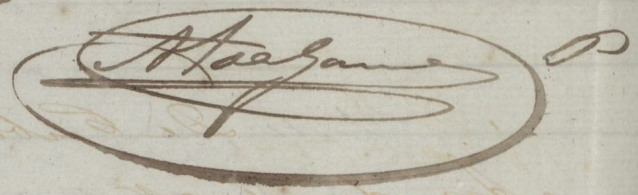

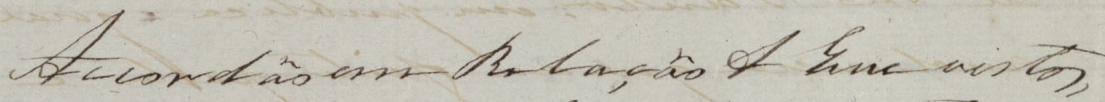

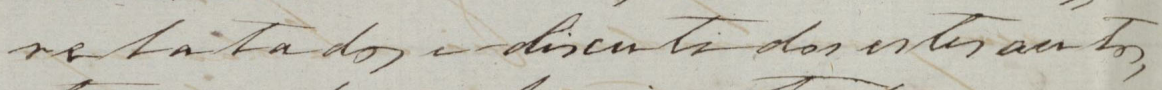

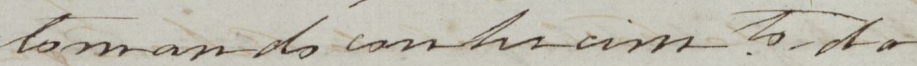

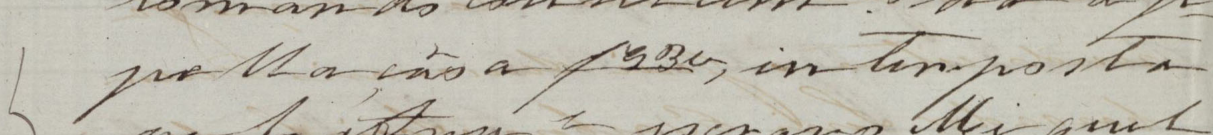

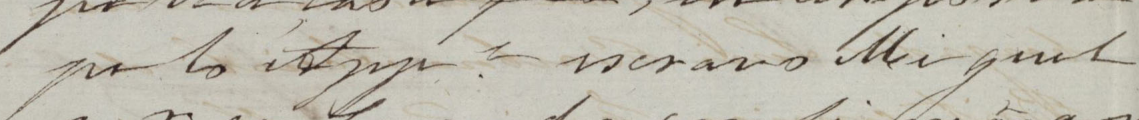

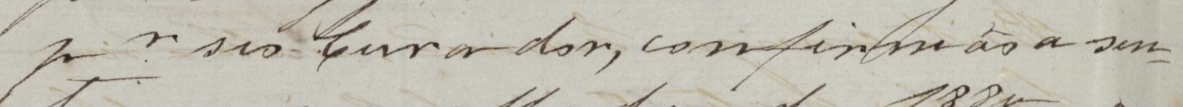
tisica a pue thata de pRen gi

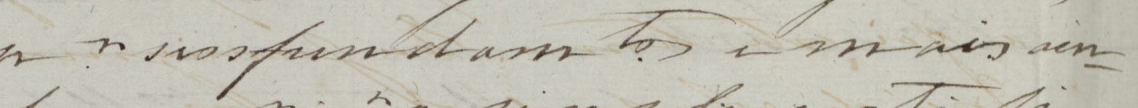

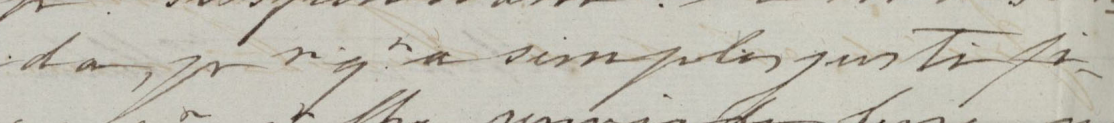
in, as -y. the sentis ale tase, mas

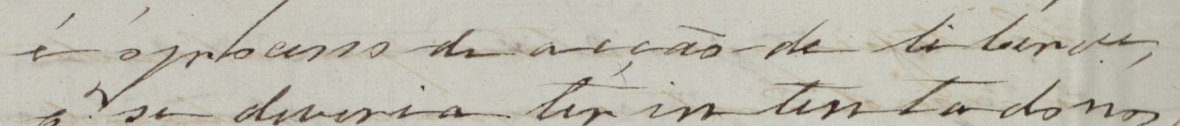
Ienmos do antage gosdo ke ger tam id

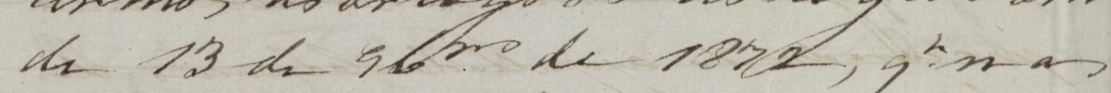

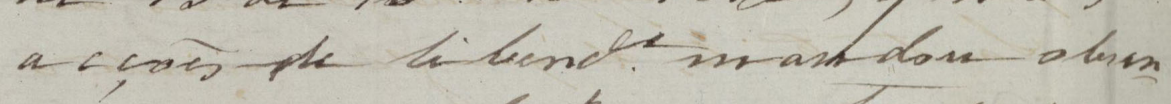

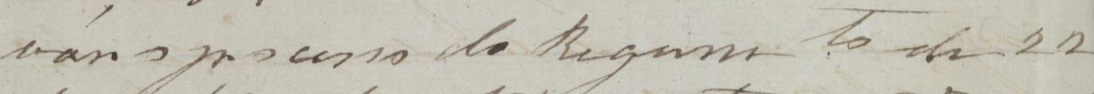

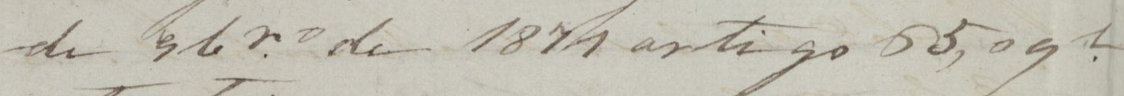

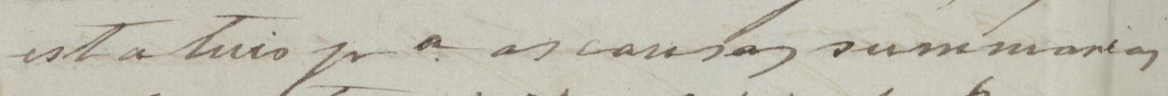

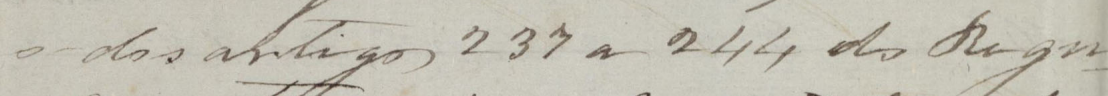

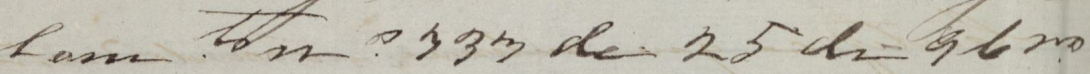
de 1850, aroing juch, amds 
Fólio 117V ${ }^{37}$

Accordaõ em Relaçaõ (ilegível) vistos, relatados e discutidos estes autos, tomando conhecimento da appellaçaõ a folhas 53verso, interposta

5 pelo Appellante escravo Miguel por seo Curador, confirmaõ a sentença appellada de folhas $88 \mathrm{v}$ erso, que annullou o presente processo por seos fundamentos e mais ainda, porque a simples justificaçaõ que lhe serviu de base, naõ é o processo da acçaõ de liberdade, que se deveria ter intentado nos termos do artigo 80 do Regulamento de 13 de Novembro de 1872, que nas acçoẽs de liberdade mandou (ilegível) o processo do Regulamento de 22 de Novembro de 1871 artigo 55, o que estatuio para as causas summarias e dos artigos 237 a 244 do Regulamento número 733 de 25 de Novembro de 1850, e assim julgando

37 Este fólio possui, em sua parte inicial, anotações de terceiro, que não foram editadas. 


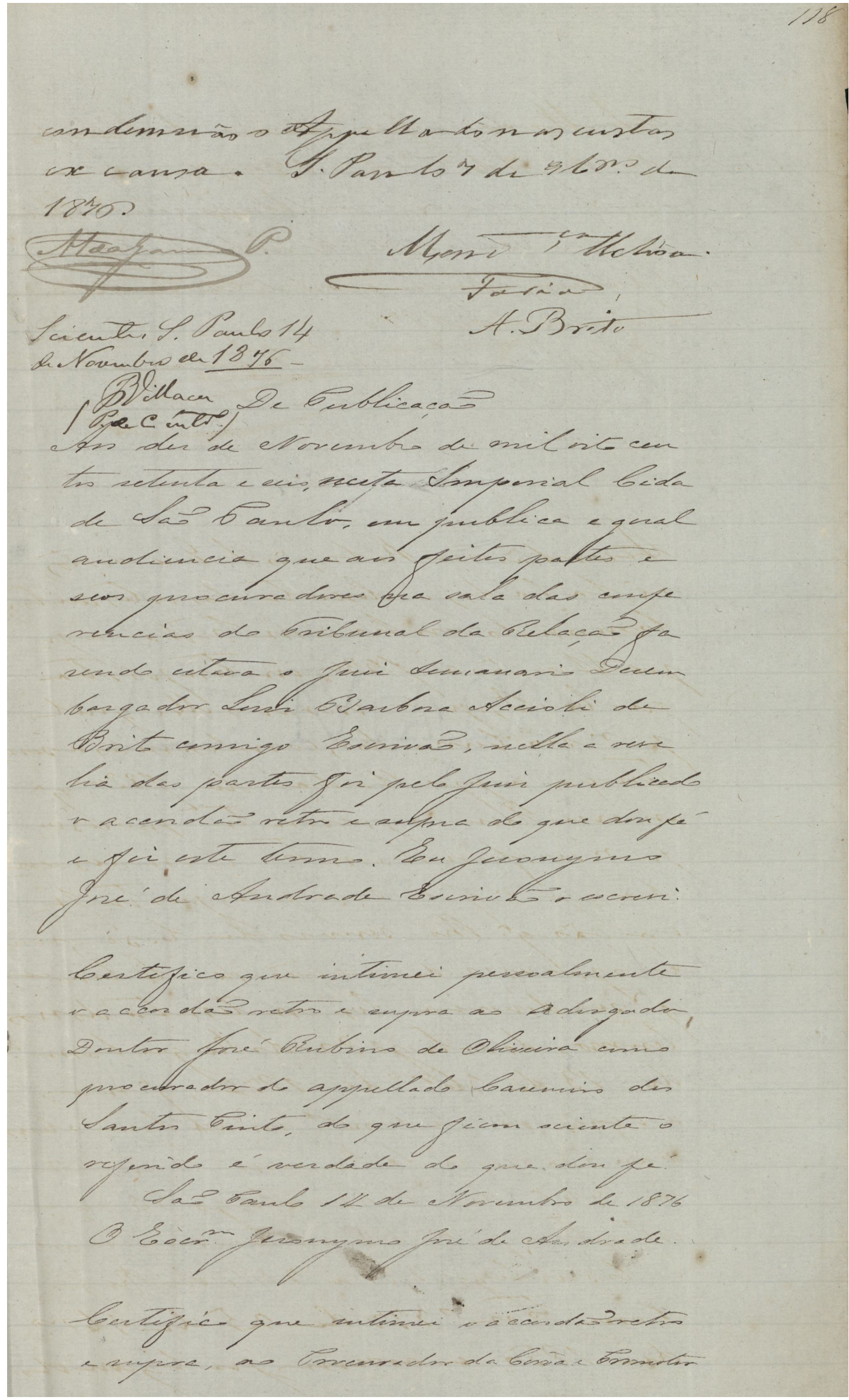


Fólio 118R

condennaõ o Appellado nas custas

ex causa. Saõ Paulo 7 de Novembro de 1876.

Agostinho Luiz da Gama Mendonça Uchôa

5 Faria

A. Brito 


\subsection{DOC 11}

Documento: Sentença

Remetente: juiz ordinário representando a Justiça Estadual de São Paulo - $1^{\mathrm{o}}$ grau

Local: Areias

Processo: 239/1876

Destinatários:

Autores: Raphael Antonio Evaristo e Jeremias Pedro Gonsalves

Réu: João Jose Dionisio

Data: 24 de Março de 1876

Juiz: Felício Ribeiro dos Santos Camargo

Descrição: 2 fólios- páginas 40 verso, 41 recto, anotados por apenas um punho, o próprio juiz proferidor da decisão. Trata-se de uma ação de manutenção de liberdade intentada por dois escravos que encontram-se em liberdade e assim pedem a manutenção desta, com uma audiência de justificação. A audiência é realizada, o réu (justificado) não comparece e o juiz julga pela falta de comprovação de citação realizada e ordena nova citação e nova audiência, anulando todo o processo até aí. 


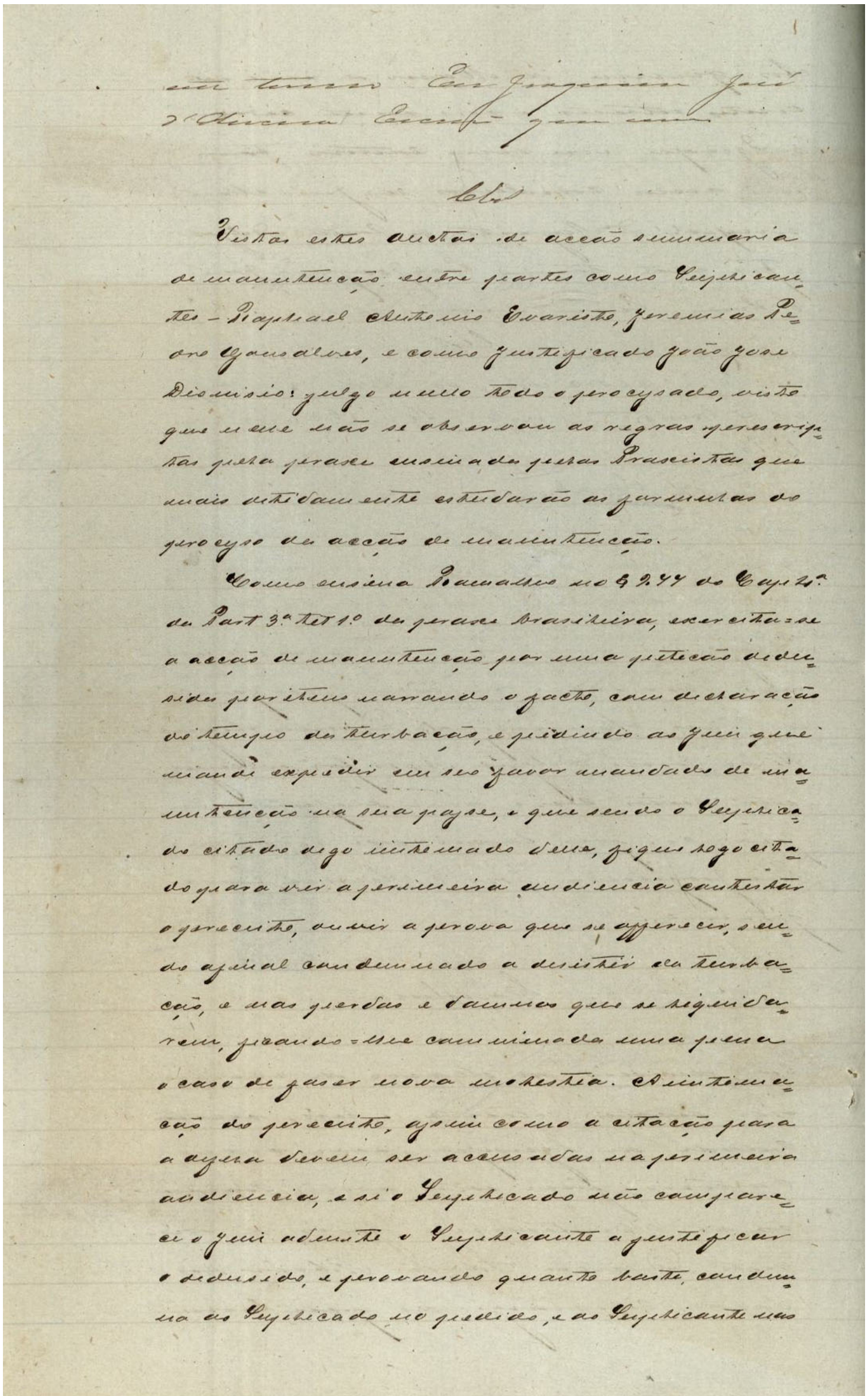


Fólio $40 \mathrm{~V} 38$

Vistos estes auctos de acçaõ summaria de manutençaõ entre partes como Justificantes Raphael Antonio Evaristo, Jeremias Pedro Gonsalves, e como justificado Joaõ Jose

5 Dionisio: julgo nullo todo o processado, visto que nelle naõ se observou as regras prescriptas pela praxe examinadas pellas (Prascistas) que mais detidamente estudaraõ as (partituras) do processo de acçaõ de manutençaõ.

10 Como ensina (ilegível) no $\S 944$ do Capítulo $2^{\mathrm{O}}$ da Parte $3^{\mathrm{a}}$ titulo $1^{\mathrm{O}}$ da praxe brasileira, exercita $=$ se a acçaõ de manutençaõ por uma petiçaõ deduzida por itens exarando o facto, com declaraçaõ do tempo da turbaçaõ, e pedindo ao juiz que mande expedir em seo favor mandado de manutençaõ na sua posse, e que sendo o Suplicado citado digo intimado dessa, fique logo citado para vir a primeira audiencia contestar o (processo), ouvir a prova que se (ilegível), sendo afinal condenado a desistir da turbaçaõ e nas perdas e dannos que se liquidarem, ficando-lhe cominado uma penna caso de fazer nova molestia. A intimaçaõ do processo, assim como a citaçaõ para a (ilegível) (verem) ser acousadas na primeira audiencia, e si Suplicado naõ comparecece o juis admite o Suplicante a justificar o deduzido, e provando quanto baste, condenna o Suplicado no pedido, e ao Suplicante nas

${ }^{38}$ Este fólio possui, em sua parte inicial, anotações de terceiro, que não foram editadas. 


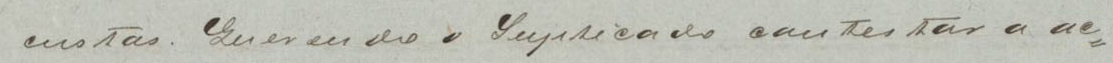

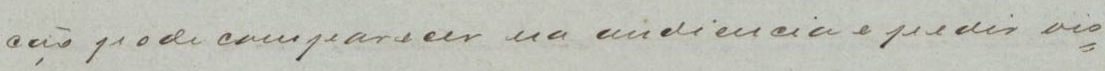

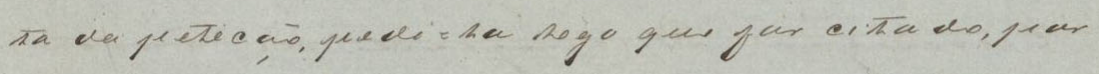

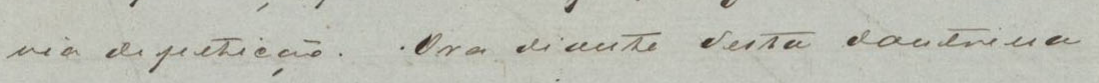

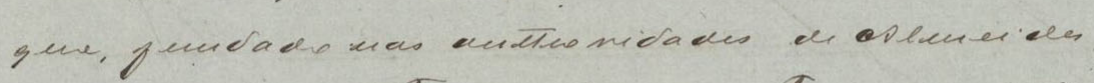

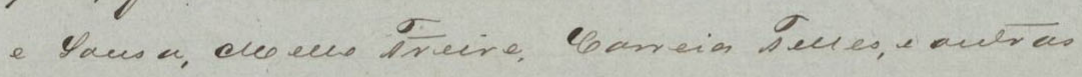

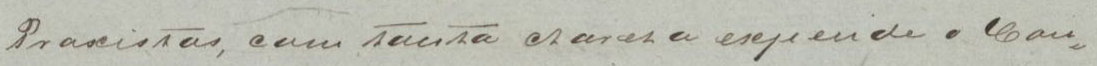

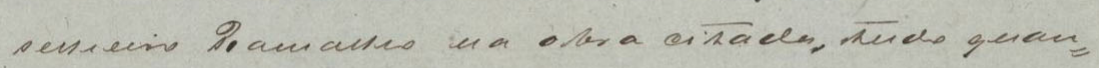

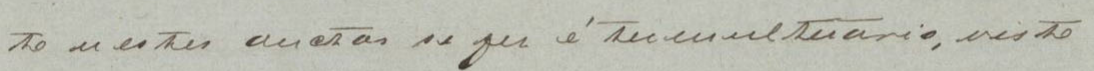

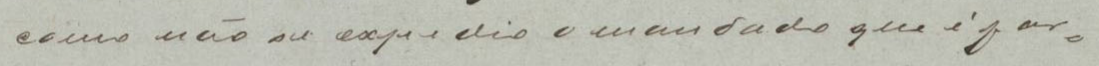

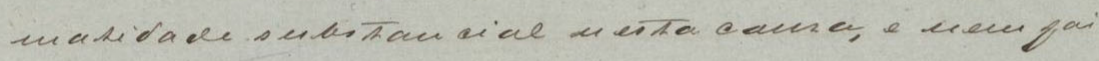

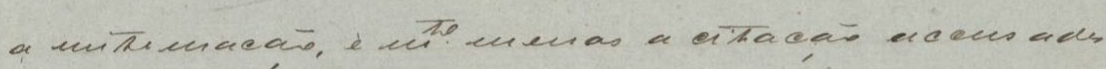

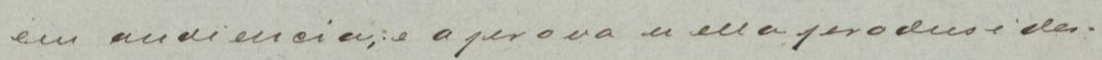

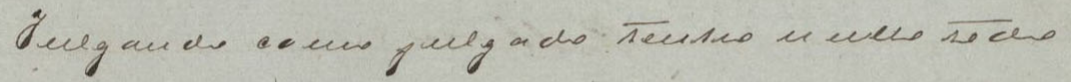

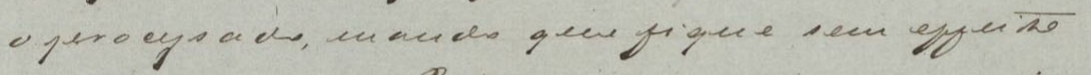

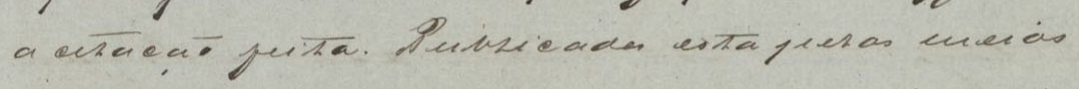
regutares oy is en yearter ivite enadas. Gerajer 2,4 de cerares de 1846 .

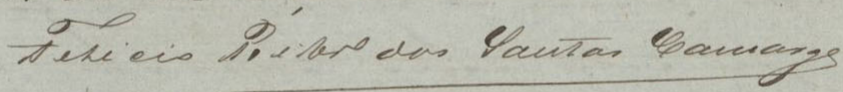

$$
\text { B) }
$$

\section{$\infty a$}

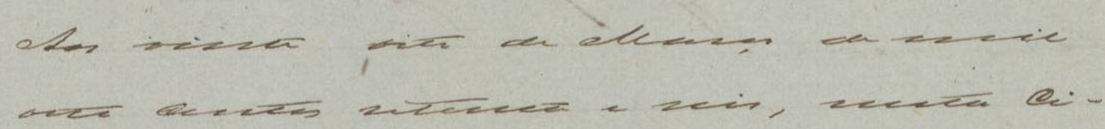

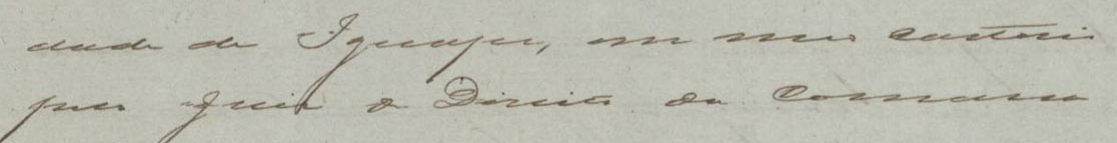

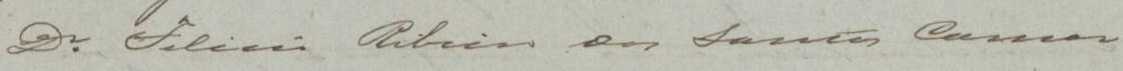

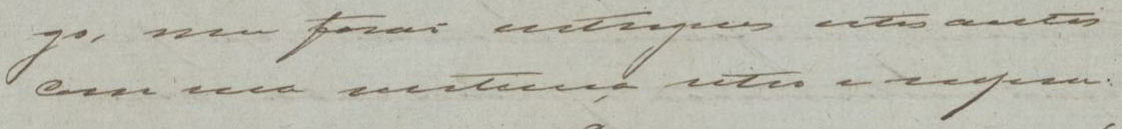

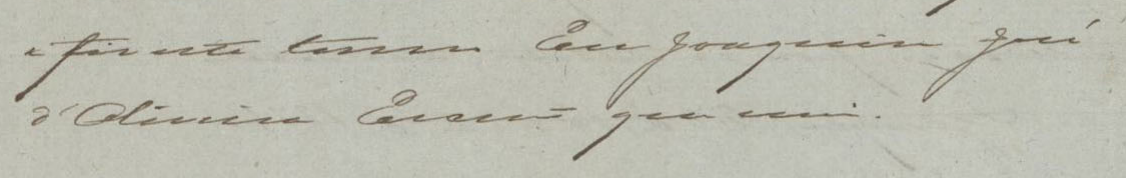

laseder 
Fólio 41R

custas. Querendo o Suplicado contestar a ac çaõ pode comparecer na audiencia e pedir vista da petiçaõ, pedi-la logo que ja citado, por via de petiçaõ. Ora diante desta doutrina

5 que, fundado nas authoridades de Almeida e Sousa, Mello Freire, Correia Telles, e outras Praxistas, com tanta clareza expende o Cassemiro Ramalho na obra citada, tudo quanto nestes auctos se fez é tumultuario, visto como naõ se expedio o mandado que é formalidade substancial nesta causa, e nem faz a intimaçaõ, é (entretanto (nellas) a citaçaõ accusada em audiencia, e a prova della produsida. Julgando como julgado tenho e anullo todo o processado, mando que fique sem effeito a citaçaõ feita. Publicada esta pellos meios regulares sejaõ as partes intimadas.

Iguape, 24 de Março de 1876.

Felício Ribeiro dos Santos Camargo ${ }^{39}$

39 Este fólio possui, a seguir, anotações de terceiro, que não foram editadas. 


\subsection{DOC 12}

Documento: Acórdão (relatório e decisão)

Remetentes: juízes desembargadores representando a Justiça Estadual de São Paulo Tribunal da Relação $-2^{\mathrm{O}}$ grau

Local: São Paulo

Processo: 239/1876

Destinatários:

Apelantes: Raphael Antonio Evaristo e Jeremias Pedro Gonsalves Apelado: João Jose Dionisio

Data: 16 de fevereiro de 1877.

Desembargador Relator: Ignácio José de Mendonça Uchôa (responsável pelo Relatório)

Descrição: 4 fólios- páginas 54 recto e verso, 55 recto e verso, sendo o relatório de um só punho, os votos pelos punhos dos respectivos desembargadores responsáveis, e a decisão pelo punho do desembargador Ignácio José de Mendonça Uchôa, confirmada pelos demais desembargadores. Trata-se de uma ação de manutenção de liberdade intentada por dois escravos que encontram-se em liberdade e assim pedem a manutenção desta, com uma audiencia de justificação. A audiência é realizada, o réu (justificado) não comparece e o juiz julga pela falta de comprovação de citação realizada e ordena nova citação e nova audiência, anulando todo o processo até aí. Os autores apelam da decisão, e o Tribunal da Relação reforma sentença, os julgando livres. 


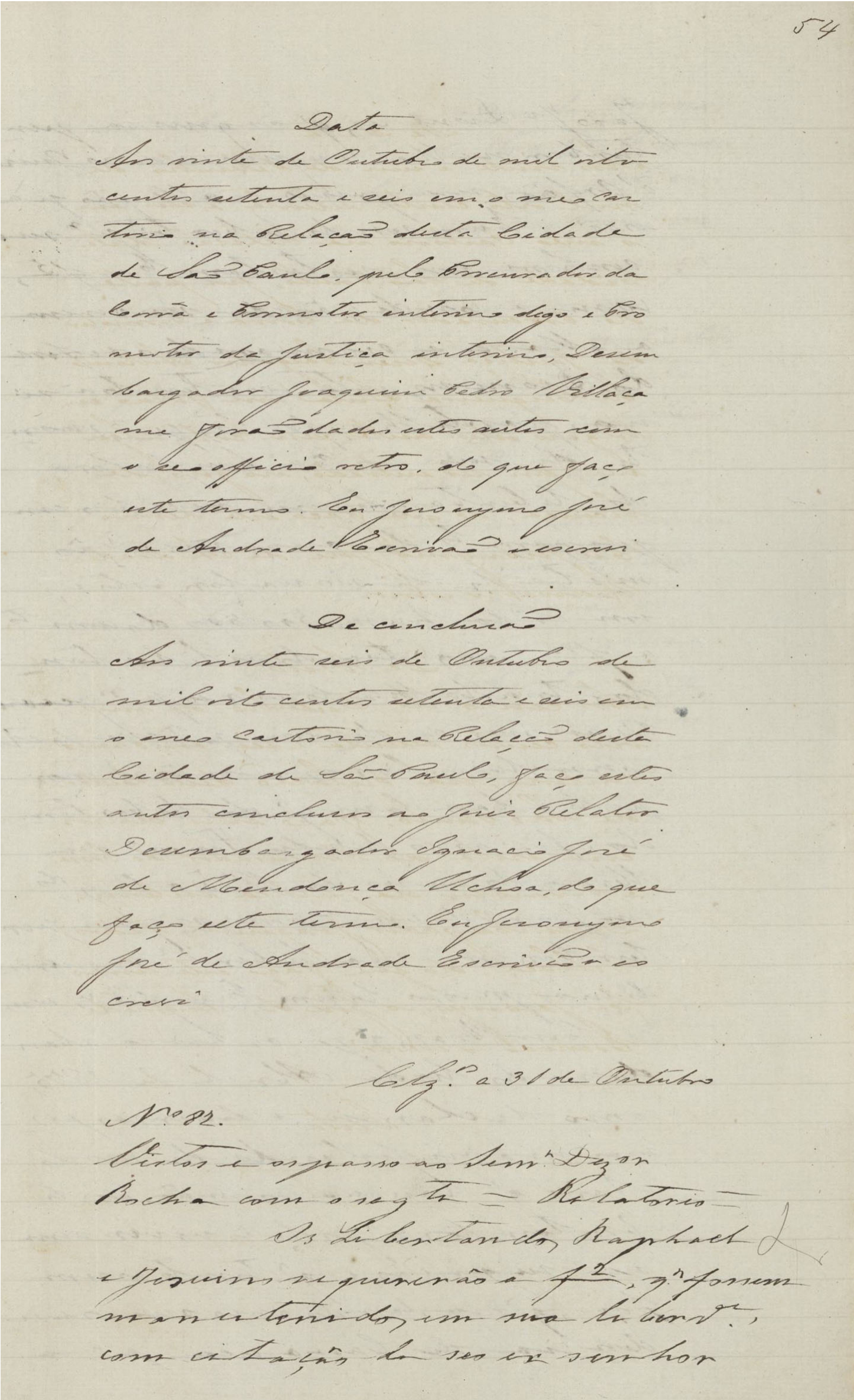


Fólio $54 \mathrm{R}^{40}$

Número 82

Vistos e os passo ao Senhor Dezembargador

Rocha com o seguinte $=$ Relatorio $=$

Os Libertandos Raphael

5 e Jesuino requereraõ a folhas2, que fossem

manutenidos em sua liberd $a$ de,

com citaçaõ do seo senhor

40 Este fólio possui, em sua parte inicial, anotações de terceiro, que não foram editadas. 
DOC 12

179

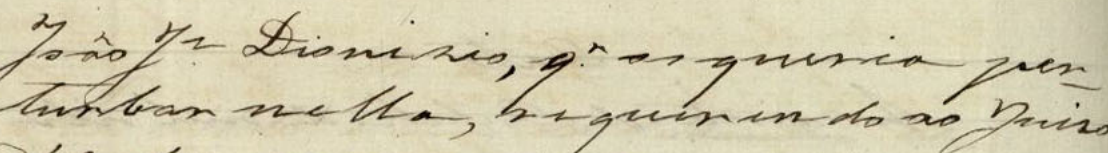

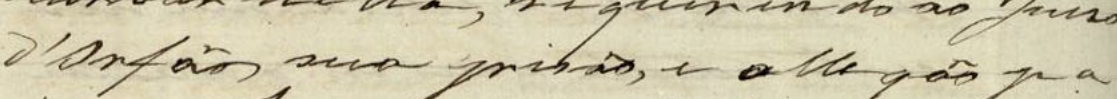

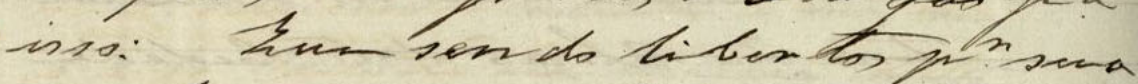

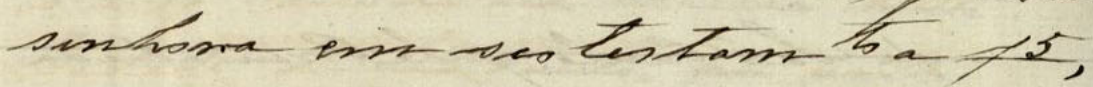
lons a cosediction de senvinese

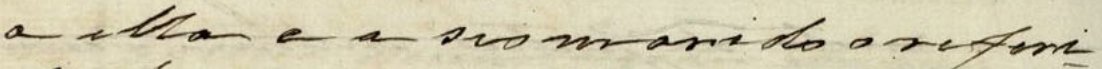

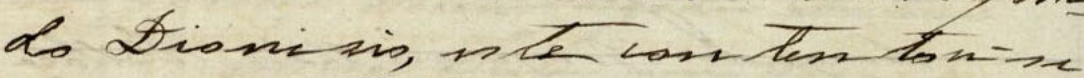

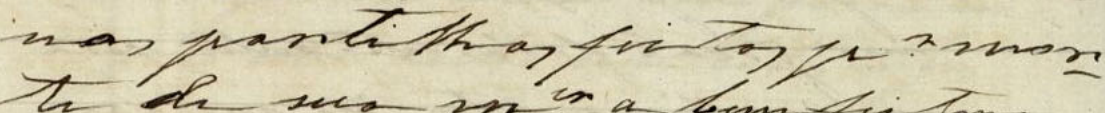
It de seca nes a himpli tara.

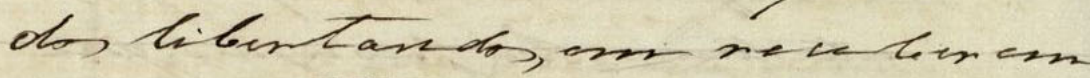

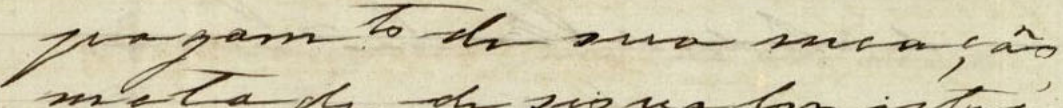

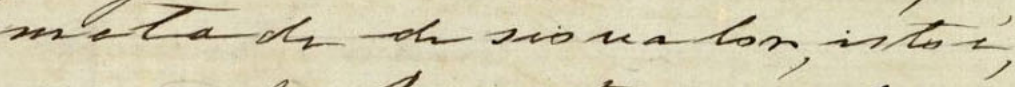
ras cha hus So0.000 docuse b

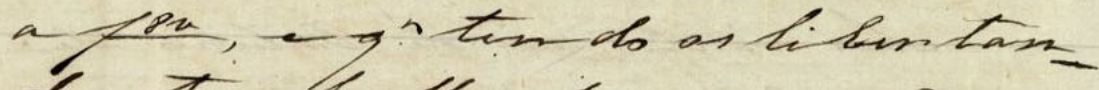

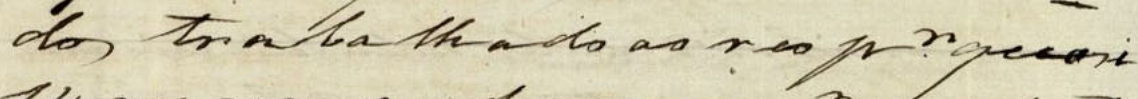

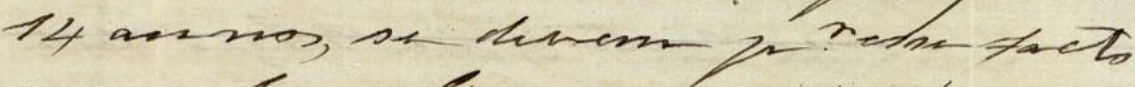

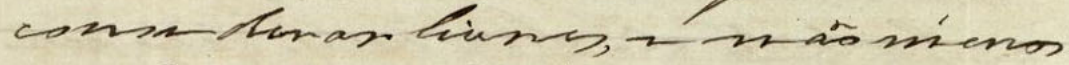

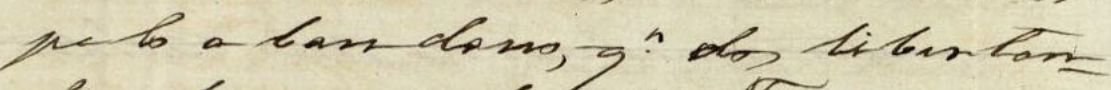

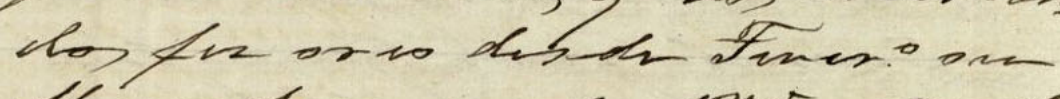

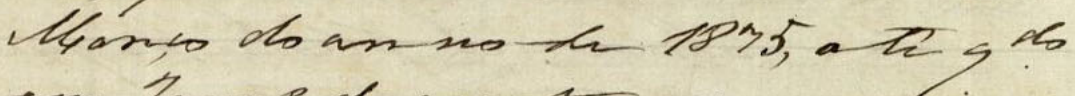

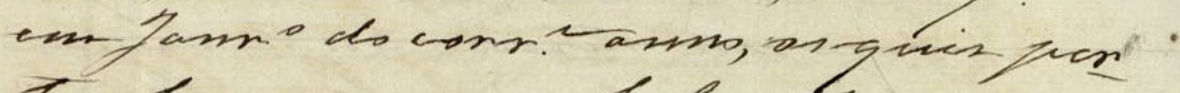

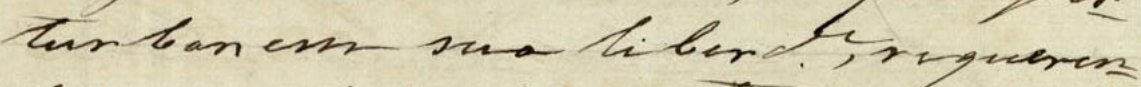

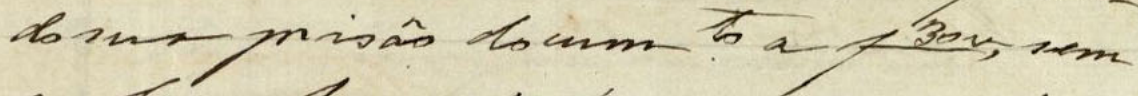

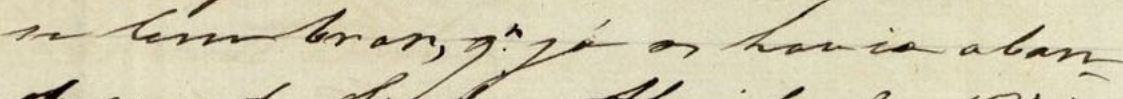

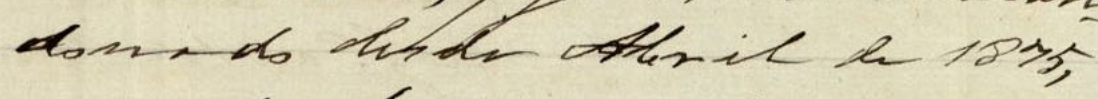

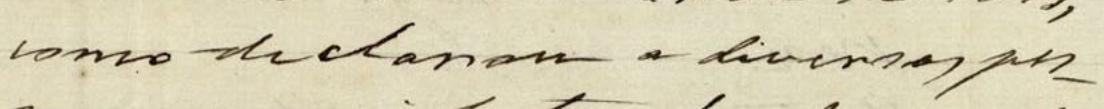
ong na nifiplas to di modo

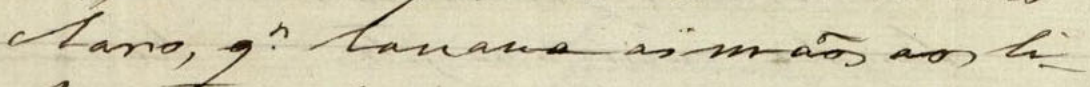

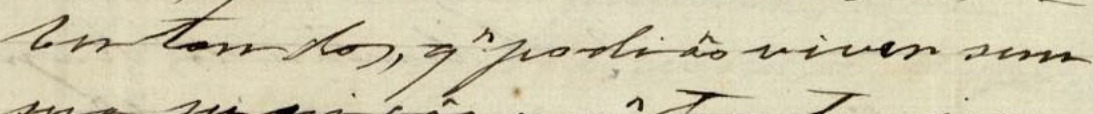

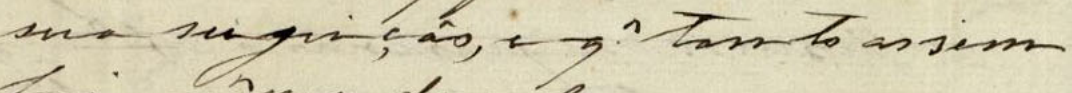

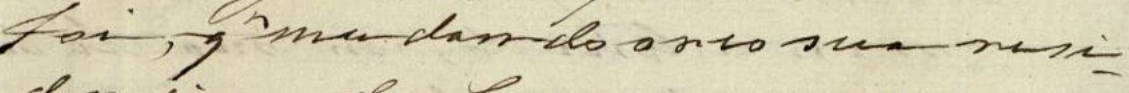
den Eia de laswa wea os a a 
Fólio 54V

Joaõ Jose Dionisio, que as queria per-

turbar nella, requrendo ao Juiso

D' Orfaõs sua prisaõ, e allegaõ para

isso: em sendo libertos por sua

5 senhora em seo testamento a folhas5,

com a condiçaõ de servirem

a ella e a seo marido o referi-

do Dionisio, este contentou-se

nas partilhas feitas por mor-

te de sua (mulher) a benfeitora

dos libertandos, em receber em

pagamento de sua meaçaõ

metade de seo valor, isto é,

em cada hum 500.000 documento)

15 a folhas $8 v$ erso, e que tendo os libertan-

dos trabalhado ao reo por quasi

14 annos, se devem por esse facto

considerar livres, a naõ menos

pelo a (ilegível) dono, que dos libertan-

20

dos fez (ilegível) desde Fever eiro ou

Março do anno de 1875, até quando

em Janneiro do corrente anno, as quis per-

turbar em sua liberdade, requeren-

do sua prisaõ documento a folhas30verso, sem

25 se lembrar, que já os havia aban-

donado desde Abril de 1875,

como declarou a diversas pes-

soas, manifestando de modo

claro, que (ilegível) as maõs aos li-

bertandos, que podiaõ viver sem

sua sujeiçaõ, e que tanto assim

foi, que mudando o reo sua resi-

dencia de Comarca para a 


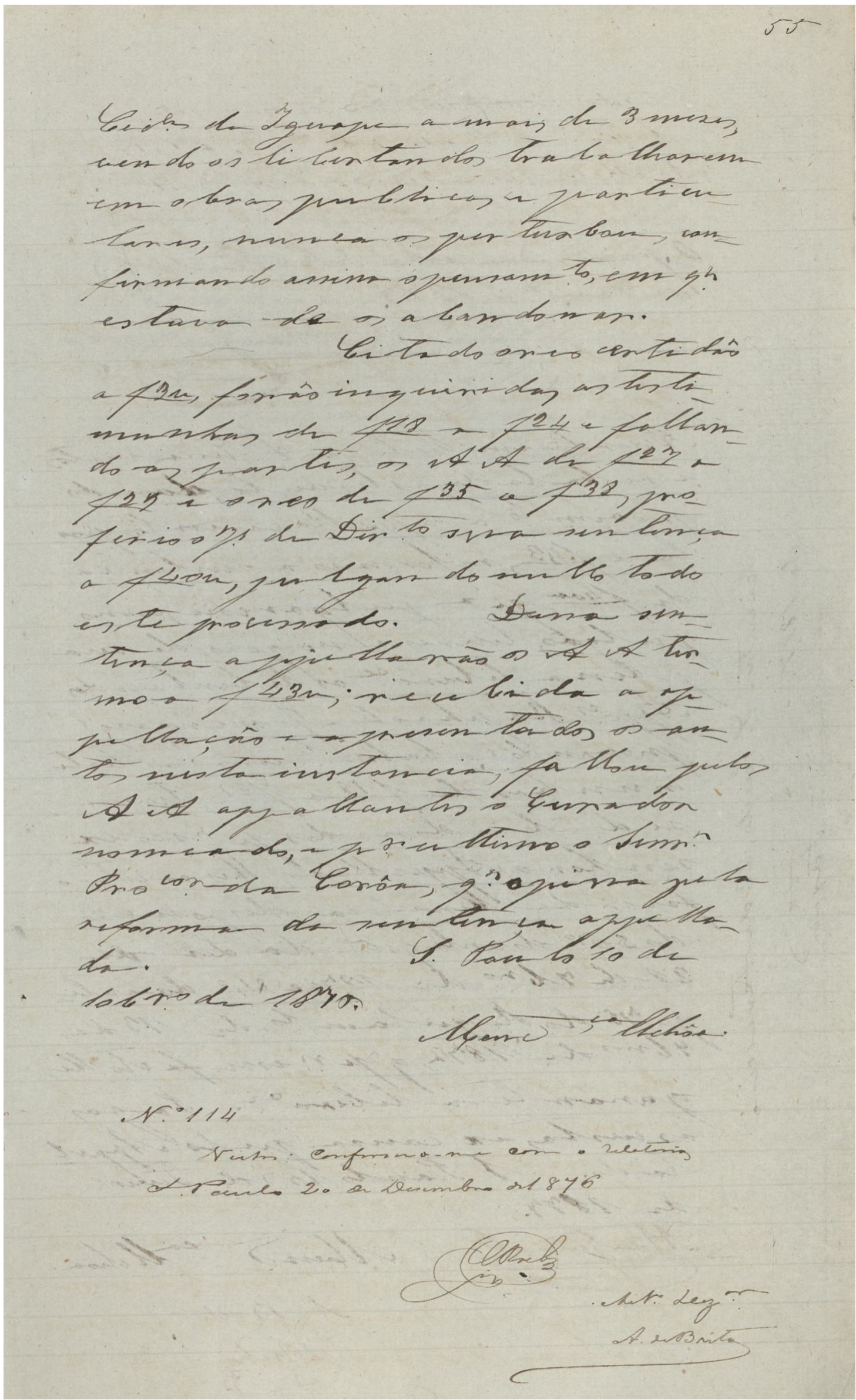


Fólio 55R

Cidade de Iguape a mais de 3 meses, vendo os libertandos trabalharem em obras publicas e particulares, nunca os perturbou, con-

5 firmando assim o pensamento, em que estava de os abandonar.

Citado o reo certidaõ a folhas3verso, foraõ inquiridas as testemunhas de folhas 18 a folhas 24 e fallando as partes, os Autores de folhas 27 a folhas 29 e o reo de folhas 35 a folhas 38 , proferio o Juiz de Direito sua sentença a folhas 40, julgando nullo todo este processado. Dessa sentença appellaraõ os Autores termo a folhas43verso; recebida a appellaçaõ e apresentados os autos nesta instancia, fallan pelos Autores appellantes o Curador nomeado, e por ultimo o Sennhor

Procurador da Corôa, que opina pela reforma da sentença appellada. Saõ Paulo, 10 de Dezembro de 1876.

\section{Mendonça Uchôa}

Número 114

Vistos: Conformo-me com o relatorio

Saõ Paulo 10 de Dezembro de 1876

Antonio Candido da Rocha

30 Ao Senhor Dezembargador

Accioli Brito 
DOC 12

183

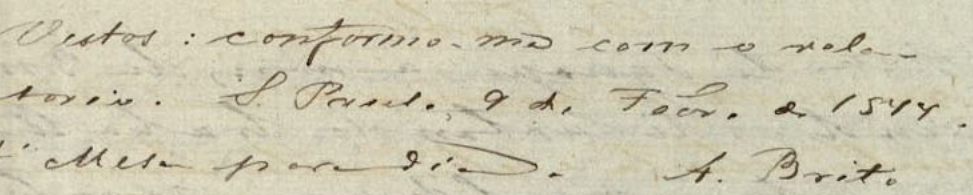

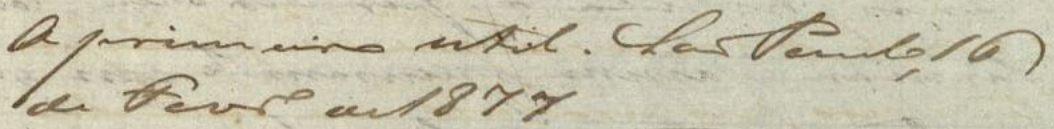

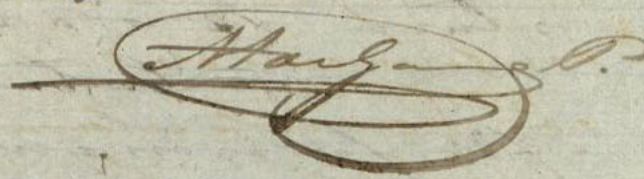

10

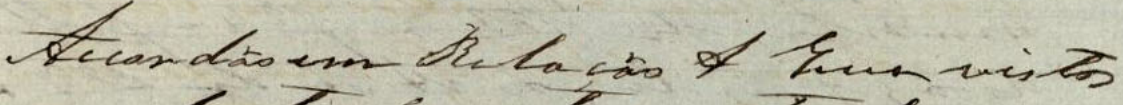

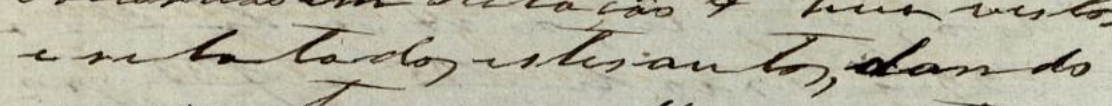
povism to a apyella, tas ins texyas if is la a 143 mefomm în- sentemen

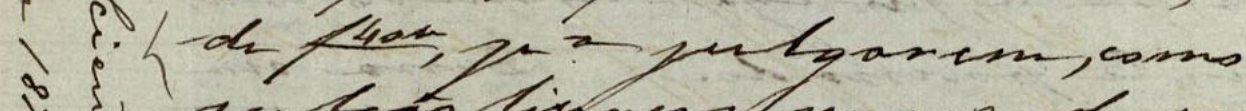

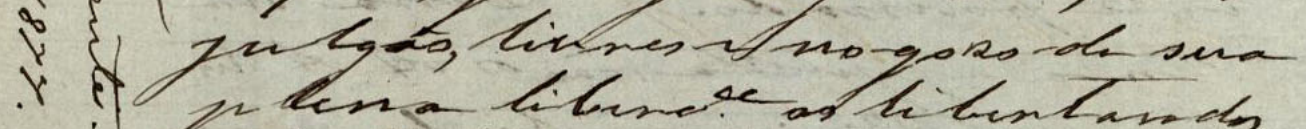
1 plena liburex as hitintands

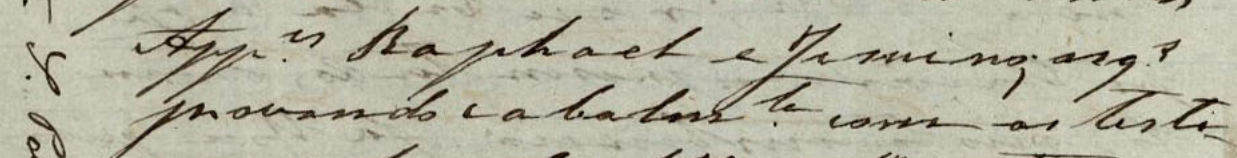

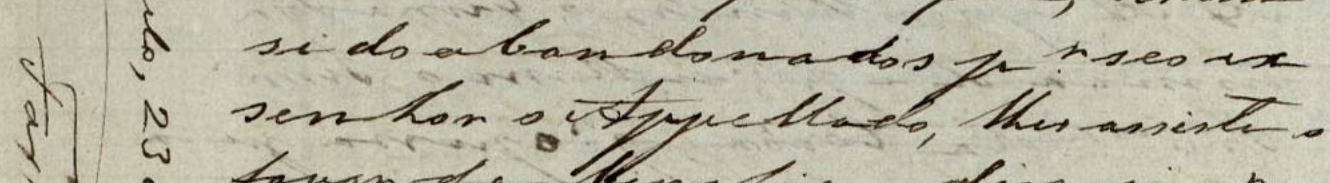

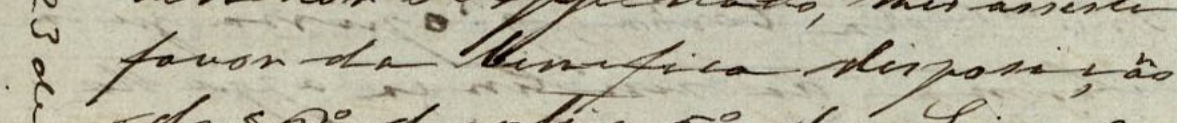
dosoxe do ankiyoori-da Lei de

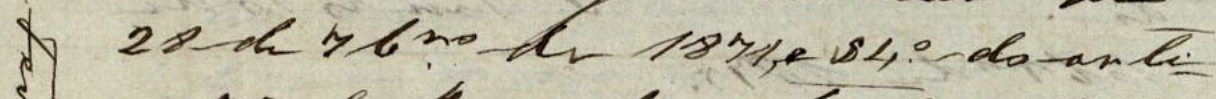

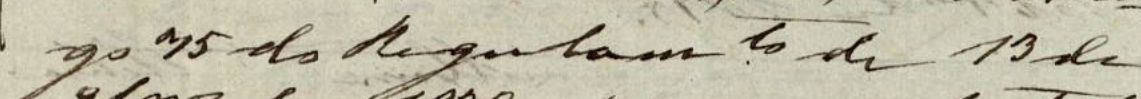

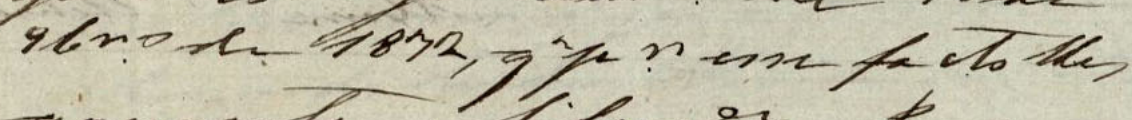

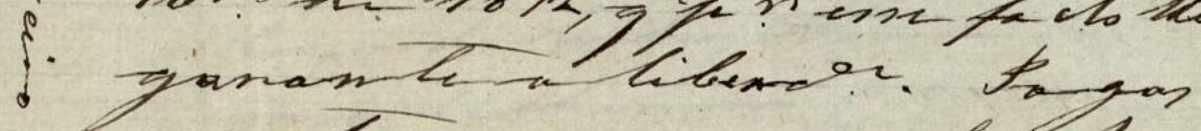

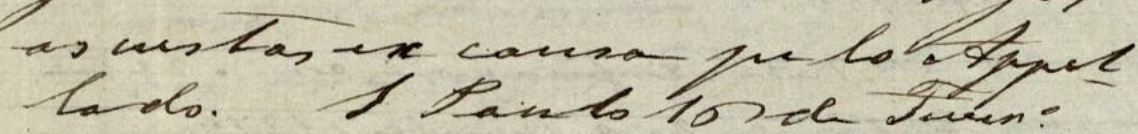
de 1893 .

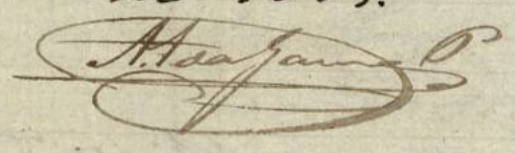

thend stlehoa.

A. Brito

asmen 
Fólio $55 \mathrm{~V}^{41}$

Vistos: conformo-me com o rela-

torio. Saõ Paulo, 9 de Fevereiro de 1877.

Á mesa para dia. Accioli Brito ${ }^{42}$

5 Accordão em Relaçaõ (ilegível) Em vistos

e relatados estes autos, dando

provimento a appellaçaõ interpos-

ta a folhas 43, reformaõ a sentença

de folhas40verso para julgarem, como

10 julgaõ, livres no goso de sua

plena liberd $a$ de os libertandos

Appellantes Raphael e Jenoíno; (ilegível)

provando cabalmente com as teste-

munhas de folhas 18 a folhas 24 , tivesse

15 sido abandonados por seo ex

senhor o Appellado, lhes assiste a

favor da (ilegível) disposiçaõ

do $\S 6^{0}$ do artigo $5^{\underline{0}}$ da Lei de

28 de Setembro de 1871 , e $\S 4^{0}$ do arti-

go 75 do Regulamento de 13 de

Novembro de 1872, que por esse facto lhes

garante a liberd $a$ de. Pagas

as custas ex causa pelo Appel-

lado. Saõ Paulo 16 de Fevereiro

25 de 1877.

Agostinho Luiz da Gama

Mendonça Uchôa

Accioli de Brito

Antonio Candido da Rocha

41 Este fólio possui, na lateral e na transversal, anotações de terceiro, que não foram editadas.

42 Este fólio possui, a seguir, anotações de terceiro, que não foram editadas. 


\subsection{DOC 13}

Documento: Sentença

Remetente: juiz ordinário, representando a Justiça Estadual de São Paulo - $1^{\mathrm{O}}$ grau

Local: Guaratinguetá

Processo: $340 / 1877$

Data: 27 de julho de 1877

Juiz: José Secundino Lopes de Gomensoro

Destinatários:

Autor: Pardo Antonio Leite dos Santos

Réu: Padre Antonio Luis dos Reis França

Descrição: 6 fólios - páginas 68 recto e verso, 69 recto e verso, 70 recto e verso, 143 linhas, anotados por apenas um punho, o próprio juiz de direito proferidor da decisão. Trata-se de uma ação de liberdade intentada por um escravo, que fora batizado como livre, entretanto, encontrava-se na condição de escravo. Sentença que julga procedente o pedido do autor, confirma a validade da certidão de batismo e o declara livre. 
como eserares toi sempere tido por sue u- He= whoru Aqueda, cormo pulos cescundentes clesta ate orio que o compror corifonme o do eurren : to junto cors sutos - Relevia cinder a prosedivar,

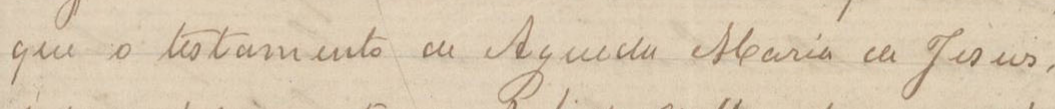
i un docimento a Sulido valtor funa o río,

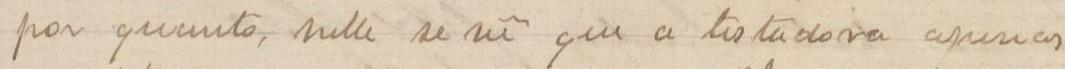
yuir berrfficiar a sue ererana La duvina, mai do ituton, istó fruna cypois de sua moñ te, e y un thos cantelora foi a nesprito as autor ede outros fithos de Soudurina; yeu clispos erapressamente que fiearicio eseranos. ebestis tiv. mor esfurana qu o Sutor fosse julg ado car

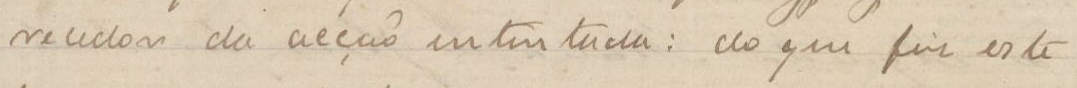
tirno fula cola tomada en men protocollo. Reasa 211960

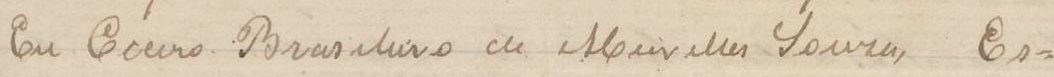
erouicio you o escreni

$$
\text { Colx }
$$

Los sinte uni cle fullwo de nill dito cuntes se =

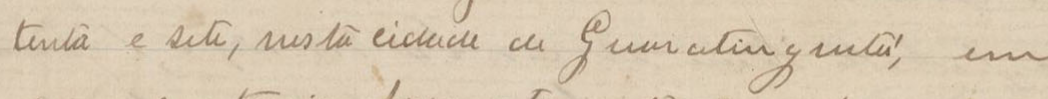
mue cartóvio, fuco es tes unios concluser as Yuisar Doulón juir de Dirvito un Comar ea

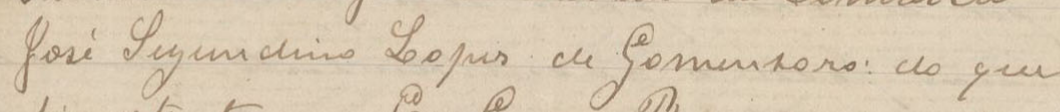

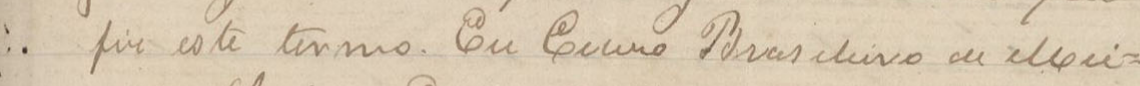

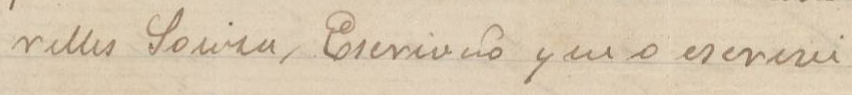

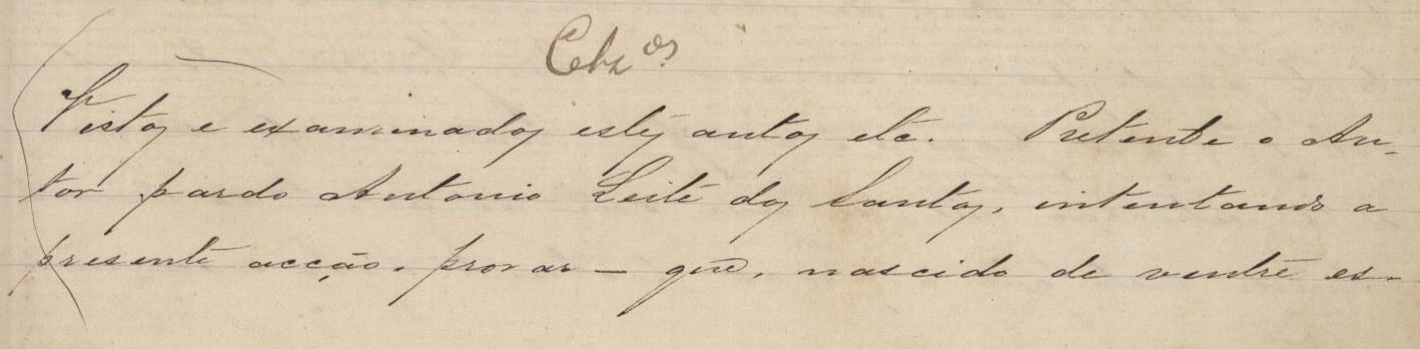




\section{Fólio $68 \mathrm{R}^{43}$}

Vistos e examinados estes autos etc. Pretende o Au

- tor pardo Antonio Leite dos Santos, intentando a

presente acção, provar - que, nascido de ventre es-

${ }^{43}$ Este fólio possui, em mais da metade de sua extenção, anotações de terceiro, que não foram editadas. 


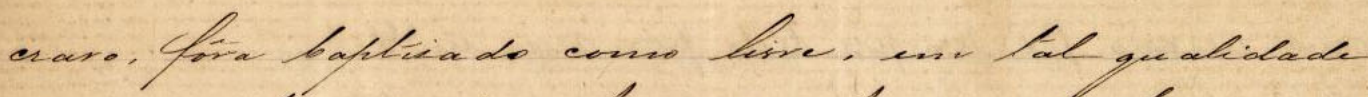

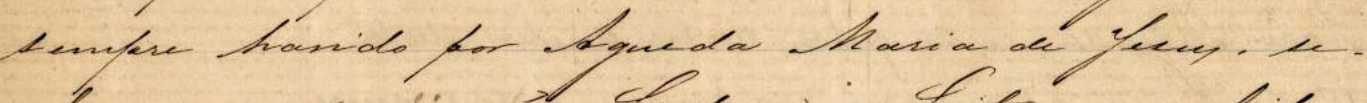

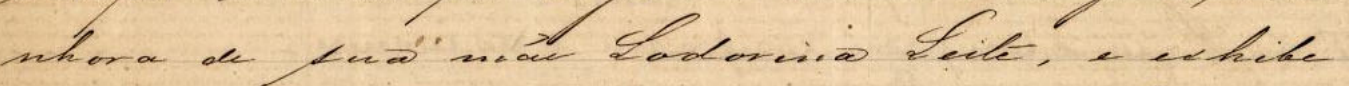

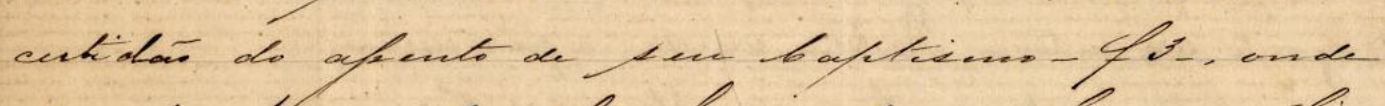

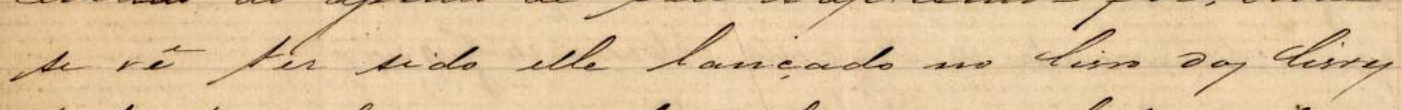

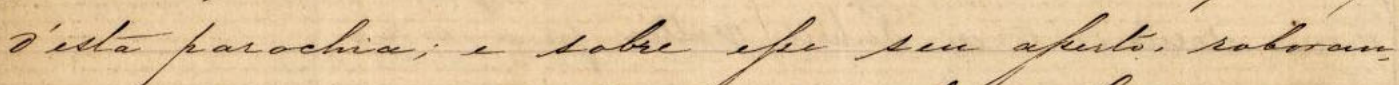

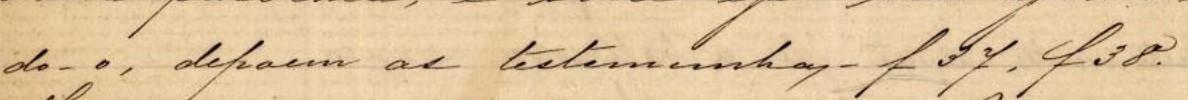

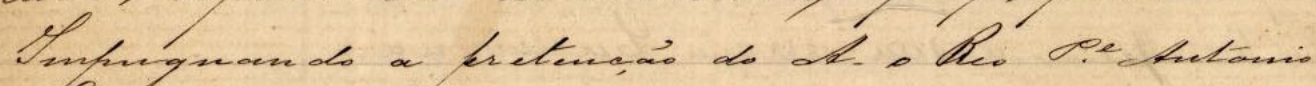

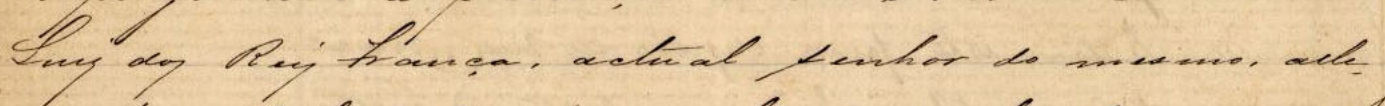

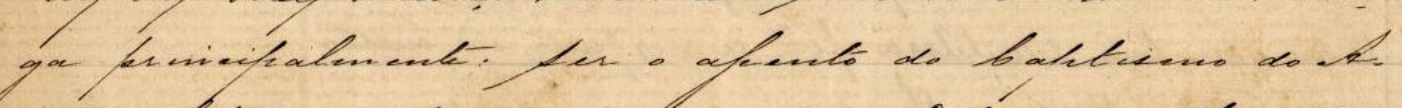

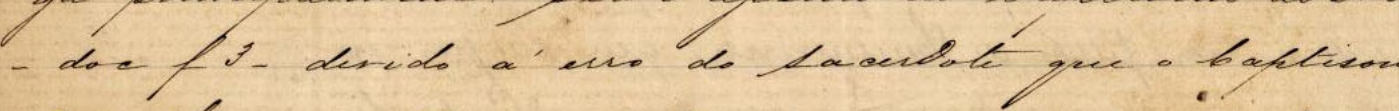

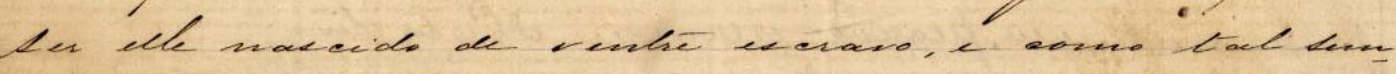

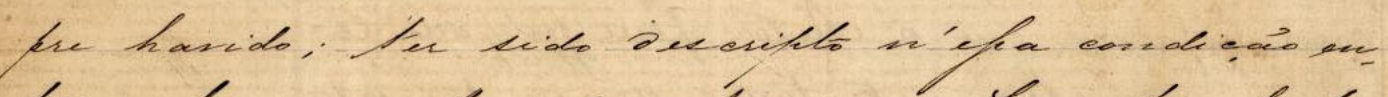

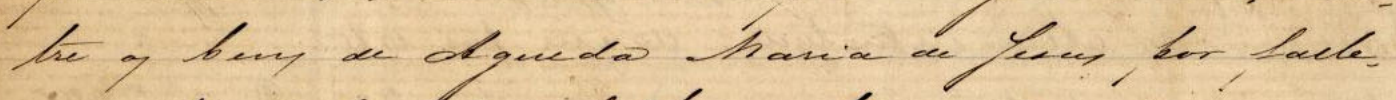

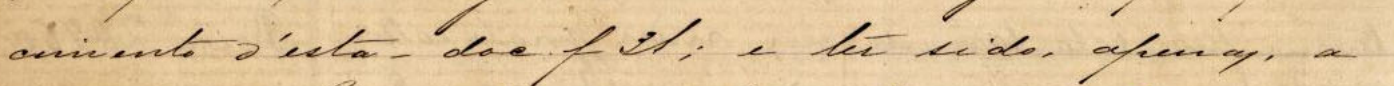

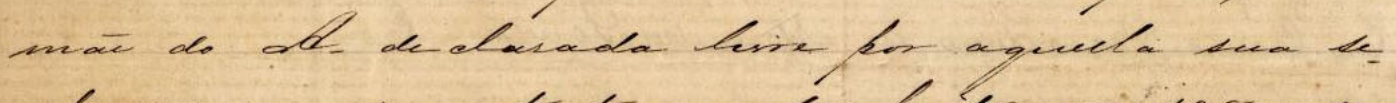

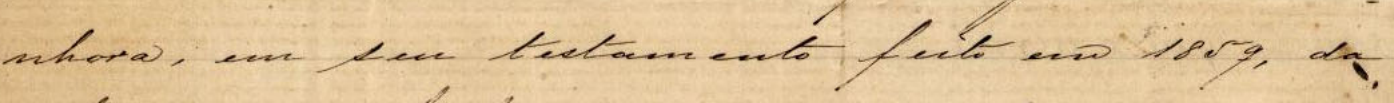

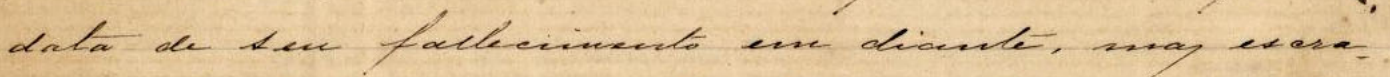

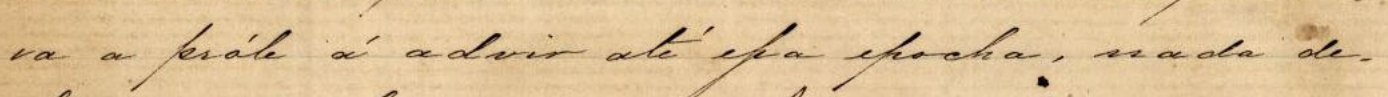

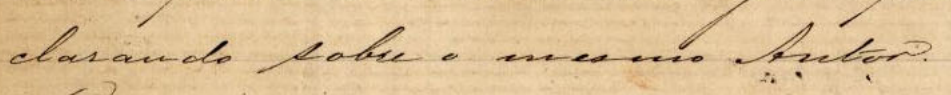

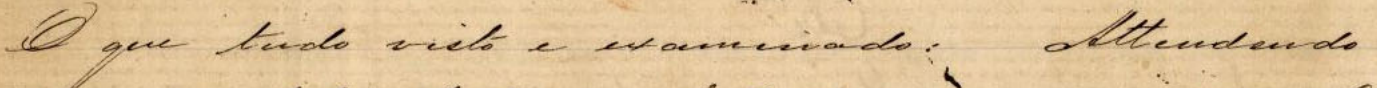

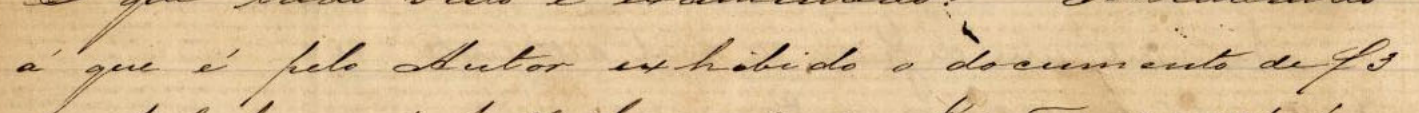

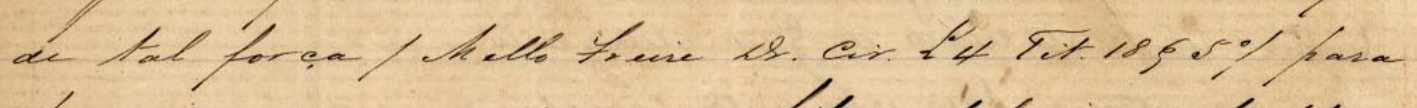

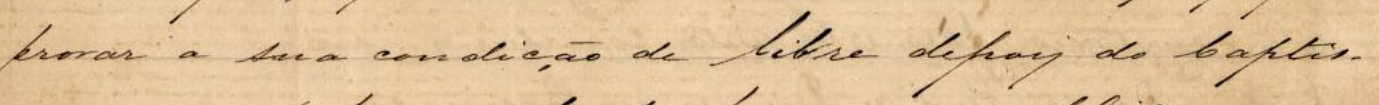

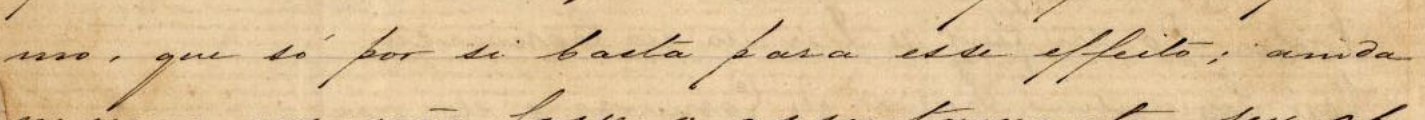

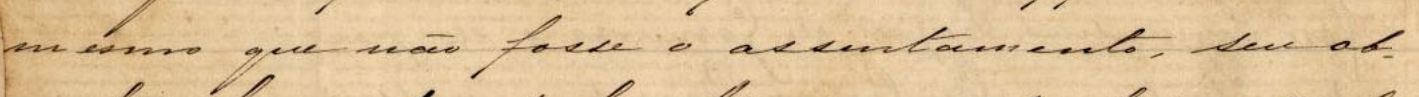

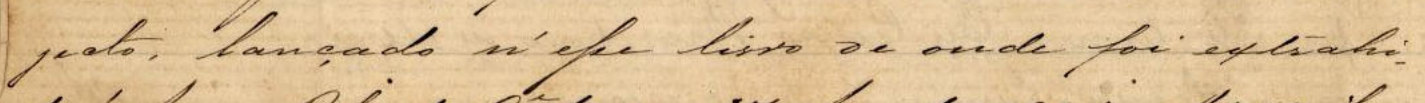

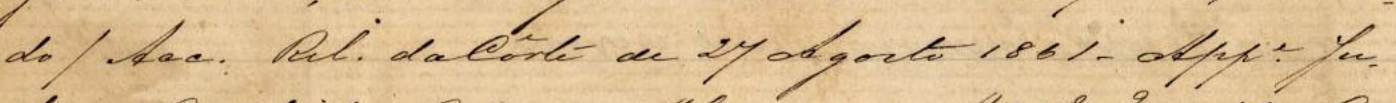

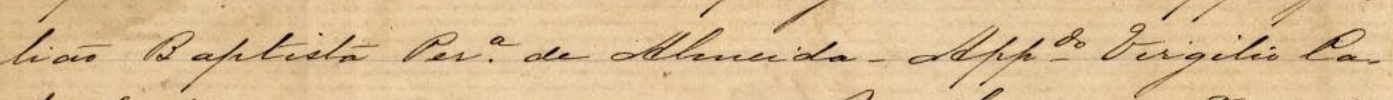

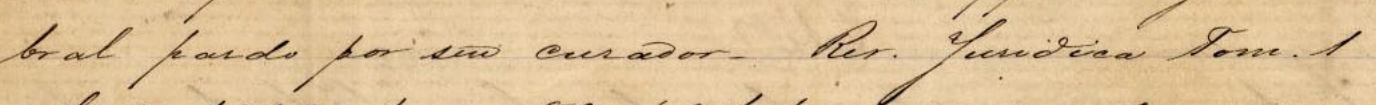

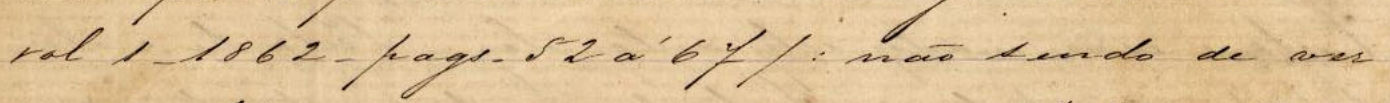

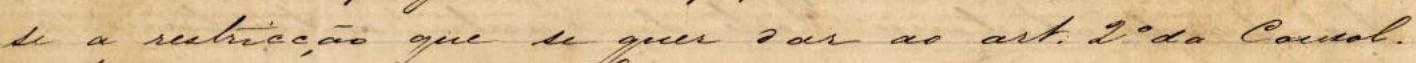

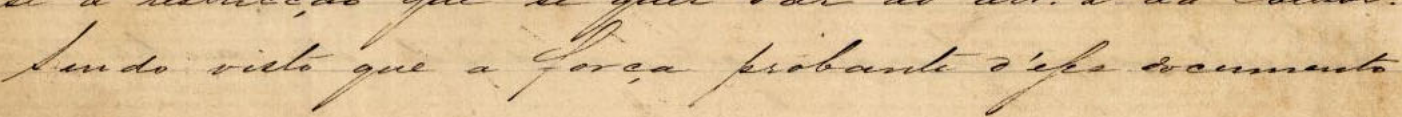


Fólio $68 \mathrm{~V}$

cravo, fôra baptisado como livre, em tal qualidade sempre havido por Agueda Maria de Jesus, senhora de sua mãe Lodovina Leite, e eshibe certidaõ do assento de seu baptismo - folhas 3 -, onde

5 se vê ter sido elle lançado no livro dos livres d'esta parochia; e sobre esse seu assento, roborando-o, depoem as testemunhas-folhas 37, folhas 38 . Impugnando a pretenção do Autor o Reo Padre Antonio Luis dos Reis França, actual senhor do mesmo, allega principalmente ser o assento do baptismo do Autor - documento folhas 3- devido á erro do Sacerdote que o baptisou ser elle nascido de ventre escravo, e como tal sempre havido; ter sido descripto n'essa condição emtre os bens de Agueda Maria de Jesus por fallecimento d'esta - documento folhas 31; e ter sido, apenas, a mãe do Autor declarada livre por aquella sua senhora, em seu testamento feito em 185[9], da data de seu fallecimento em diante, mas escrava a próle á advir até essa epocha, nada declarando sobre o mesmo Autor.

O que tudo visto e examinado. Attendendo á que é pelo Autor exhibido o documento de folhas 3 de tal força/ Mello Freire Direito Civil Livro 4 Titulo $18 \S 5^{\mathrm{o}} /$ para provar a sua condição de libre depois do baptismo, que só por si basta para esse effeito; ainda mesmo que não fosse o asssentamento, seu objecto, lançado n'esse livro de onde foi extrahido/ Accordão Relação da Côrte de 27 de Agosto de 1861 - Appellante Julião Baptista Pessoa de Almeida - Appellado Virgilio Cabral pardo por seu curador - Revista Juridica Tomo 1 Volume 1 - 1862 - paginas 52 á 67/; não sendo de vesse a restriç̧ão que se quer dar ao artigo $2^{\mathrm{O}}$ da Consolidação.

Sendo visto que a força probante d'esse documento 
mat fur illidida soms eso de suider, with conso "ajuer

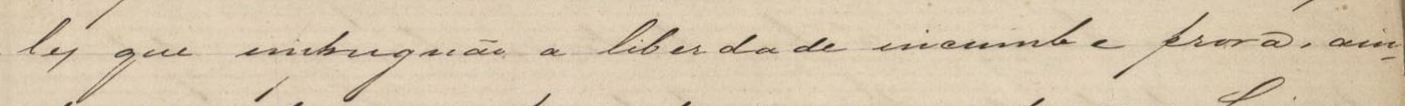

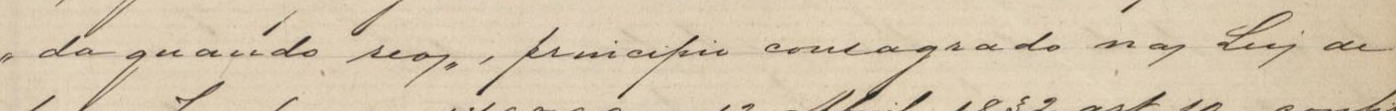

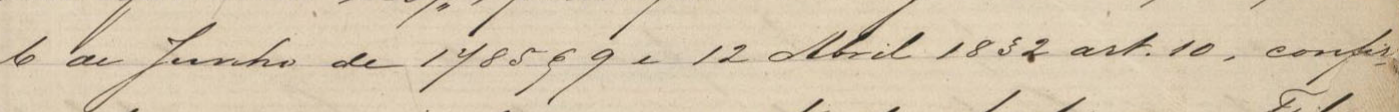

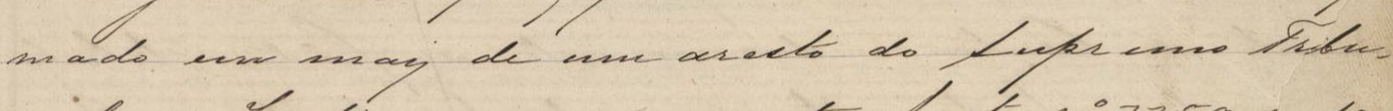

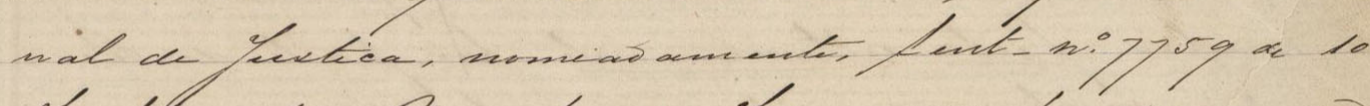

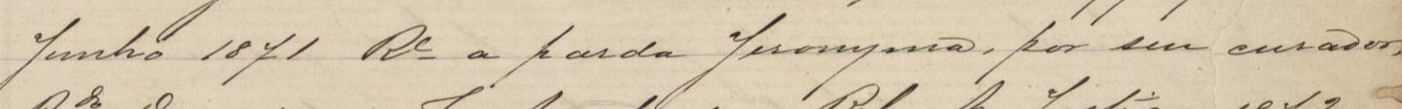

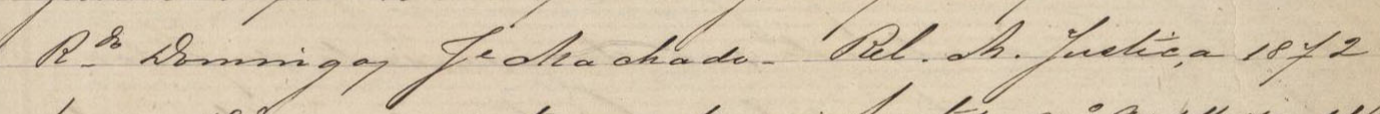

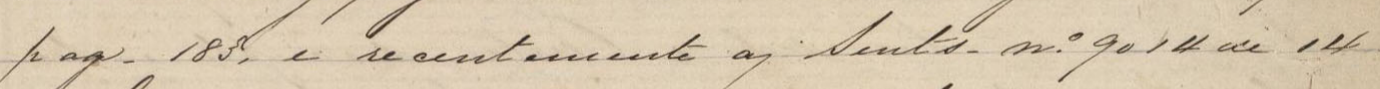

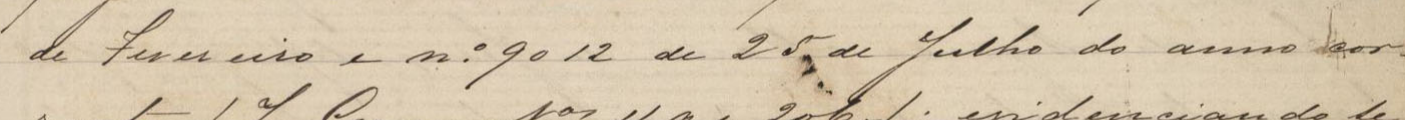

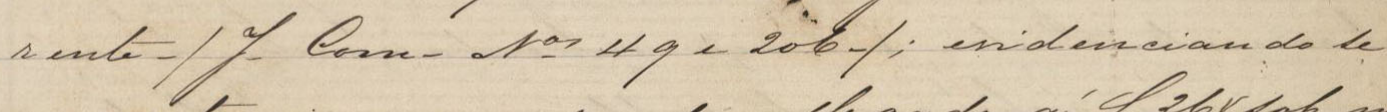

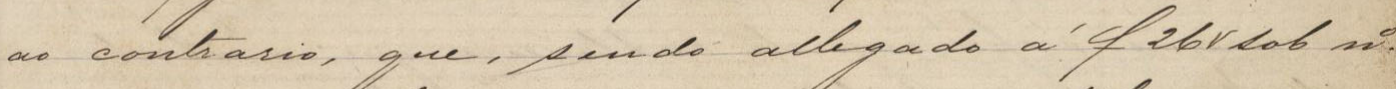

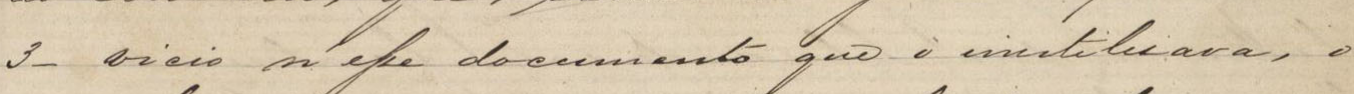
seo louge de proras. Dew afeesto abavonum

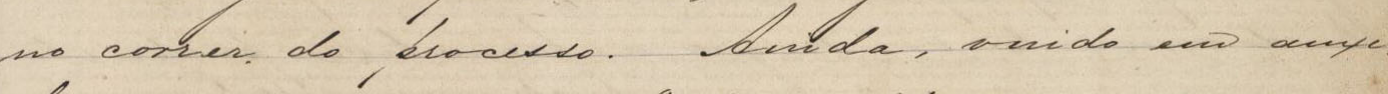

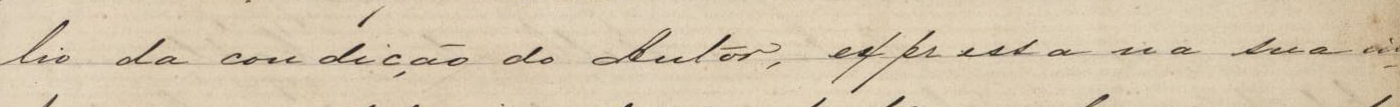

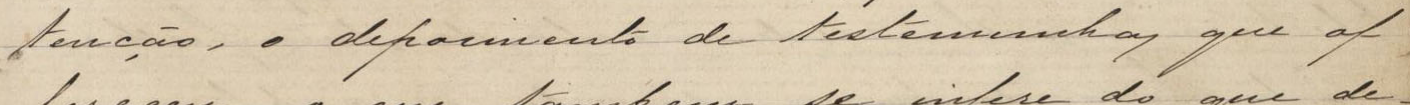

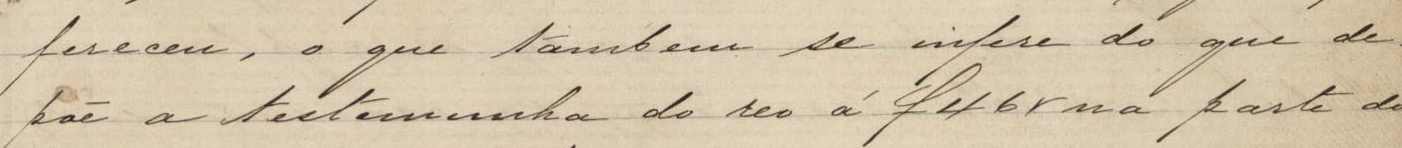

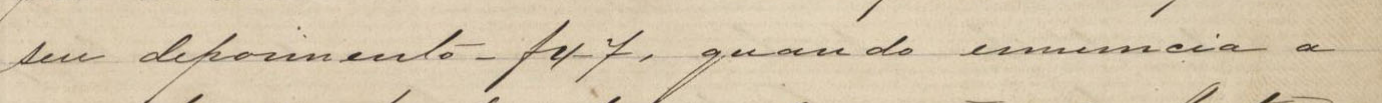

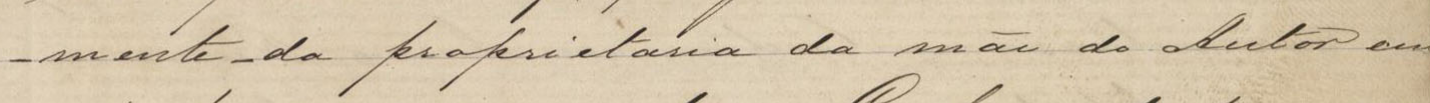

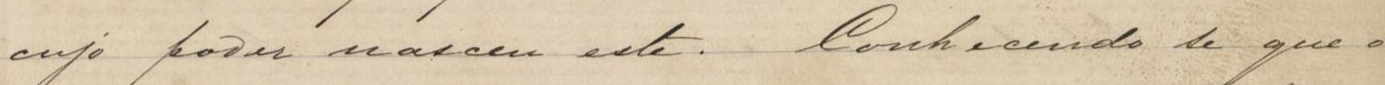

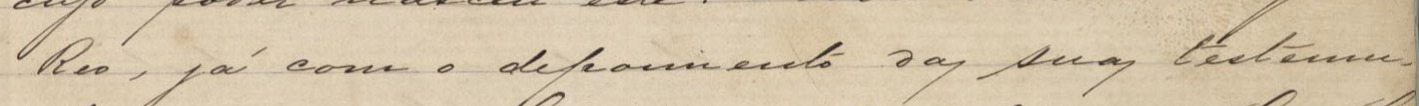

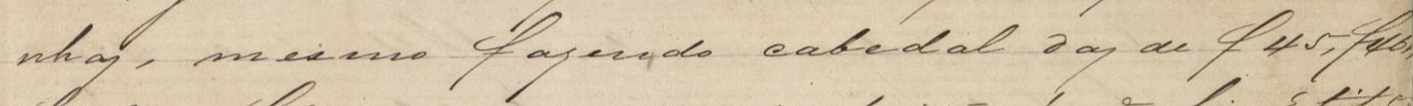

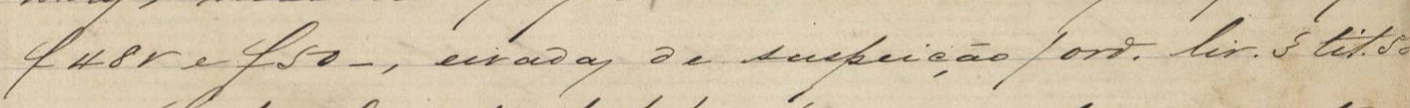

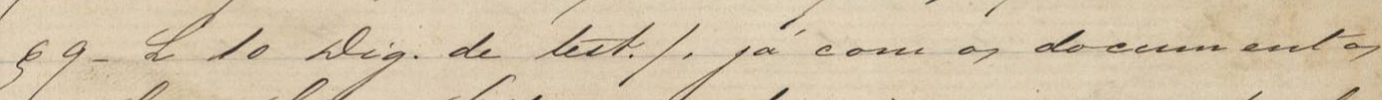

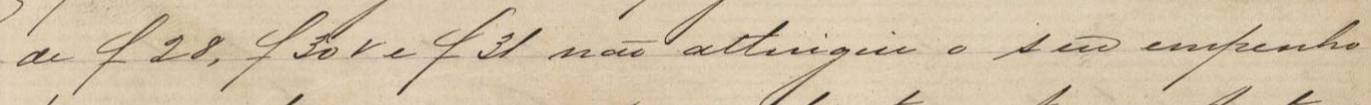
por quante, sumea le contectaver tes o odutor

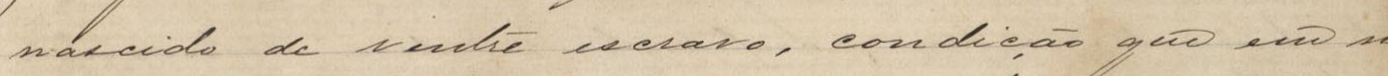

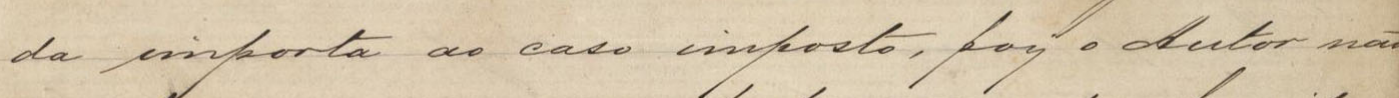

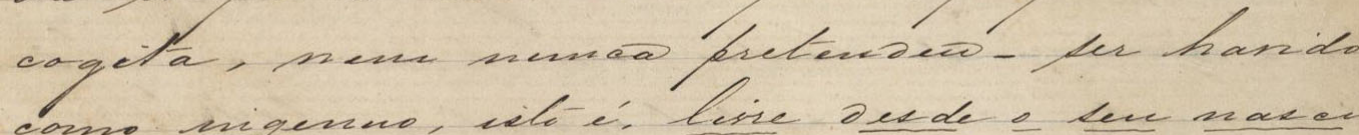

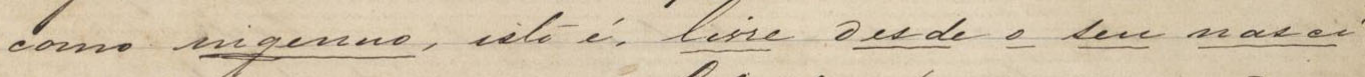

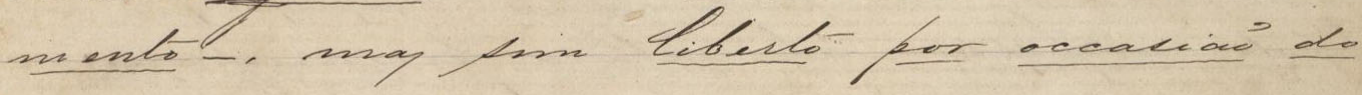


Fólio 69R

não foi ellidida como era de mister, visto como "aquel-

"les que impugnão a liberdade incumbe prova, ainda quando reos", principio consagrado nas Leis de 6 Junho de $1785 \S 9$ e 12 de Abril de 1832 artigo 10, confir-

5 mado em mais de um aresto do Supremo Tribunal de Justiça, nomiadamente, Sentença número 7759 de 10 de junho de 1871 Recorrente a parda Jeronyma, por seu curador, Recorridos Domingos (Je) Machado. Relação da Justiça 1872 pagina 183, e recentemente as Sentenças número 9014 de 14 de Fevereiro e número 9012 de 25 de julho do anno corrente -/ Julgado Comercial Números 49 e 206-/; evidenciando se, ao contrário, que, sendo allegado à folhas 26 verso sob número 3 - vicio n'esse documento que o inutilisava, o reo longe de provar o seu asserto abandonou no correr do processo. Ainda, vindo em auxilio da condição do Autor, exppressa na sua in) tenção, o depoimento de testemunhas que offerecem, o que tambem se infere do que depõe a testemunha do reo á folhas 46 verso na parte do seu depoimento - folhas 47-quando ennuncia a -mente- da proprietaria da mãe do Autor em cujo poder nasceu este. Conhecendo se que o Reo, já com o depoimento das suas testemunhas, mesmo fazendo cabedal das de folhas 45, folhas 46, folhas 48 veso e folhas 50 - eivadas de suspeição / Ordnaço/ es livro 3 titulo 58 $\S 9$ - Lei 10 (Dig) de (test.) / já com os documentos de folhas 28, folhas 30 verso e folhas 31 não attingiu o seu empenho; por quanto nunca se contestou ter o Autor nascido de ventre escravo, condição que em nada importa ao caso imposto, pois o Autor não cogita, nem nunca pretendeu - ser havido como ingenuo, isto é, livre desde o seu nacimento -,mas sim liberto por occasião do 
baftering mediante:

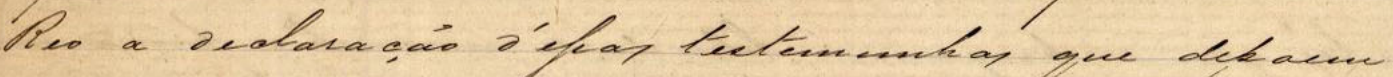

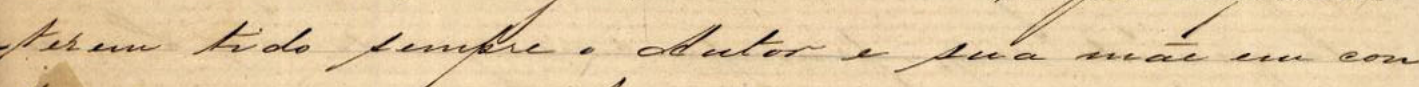

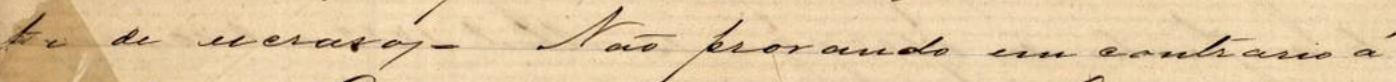

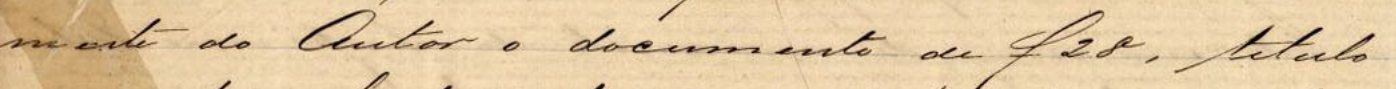

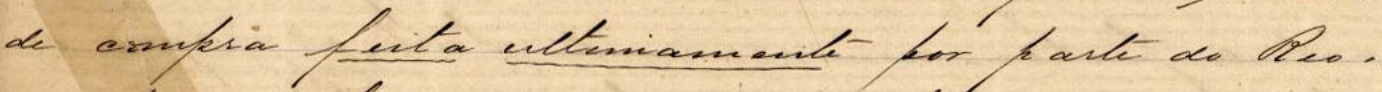

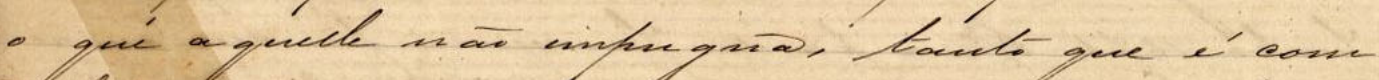

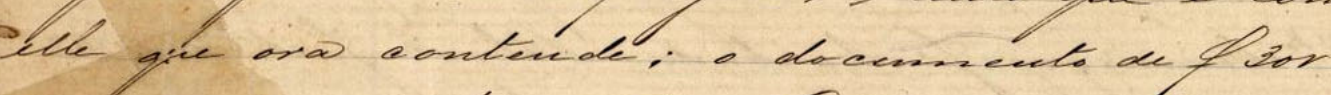

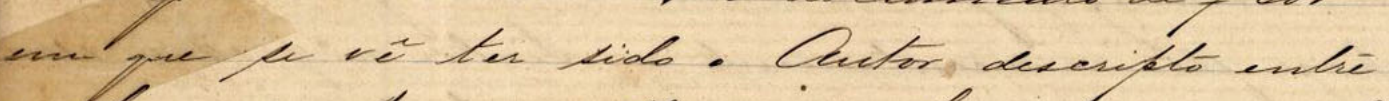

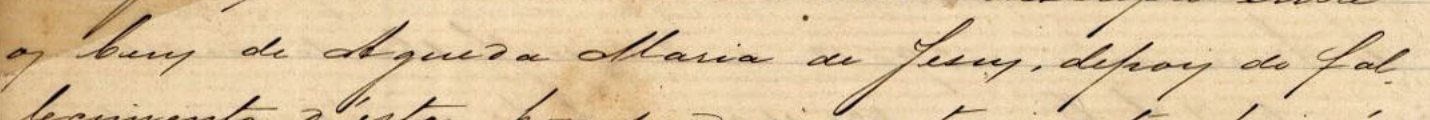

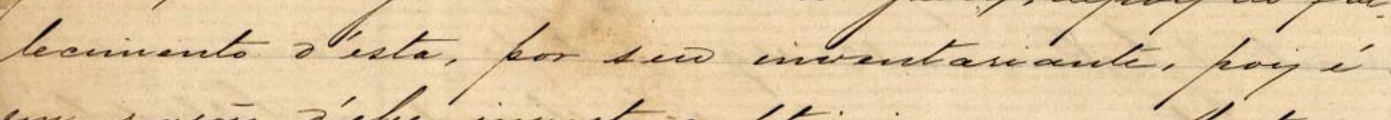

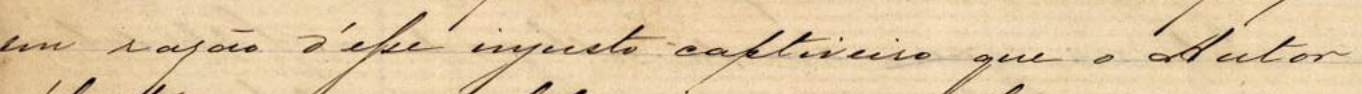

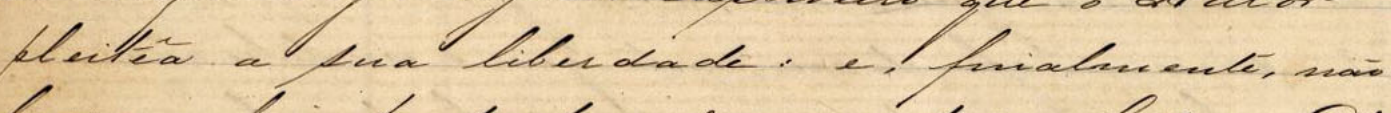

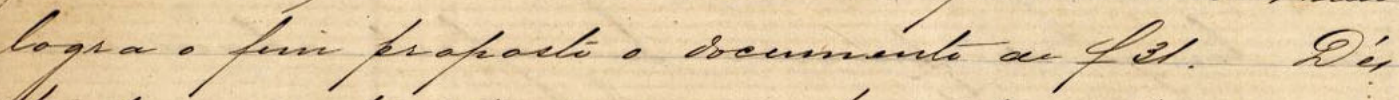

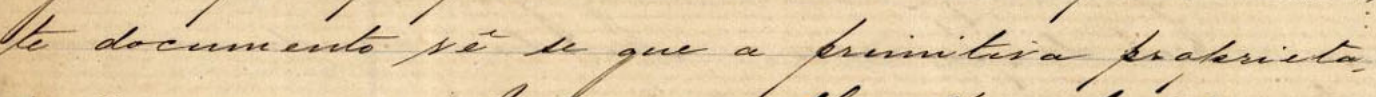

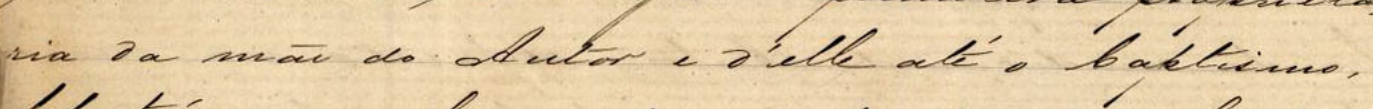

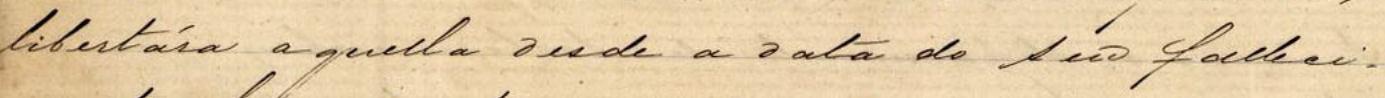

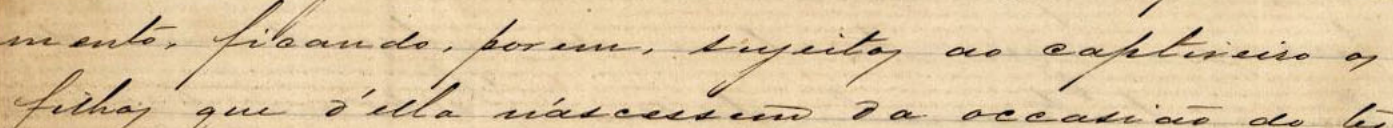

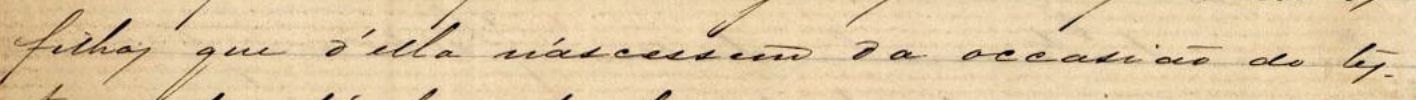

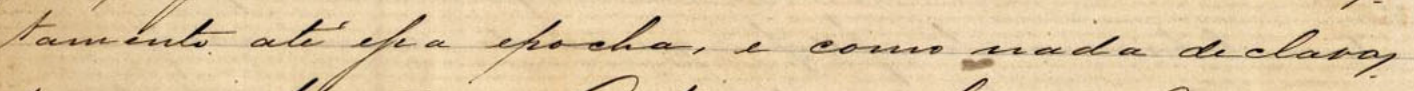

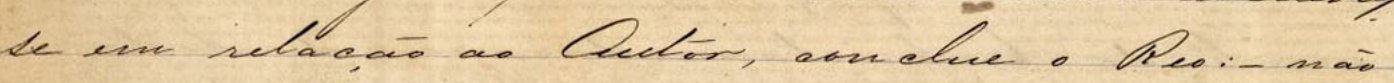

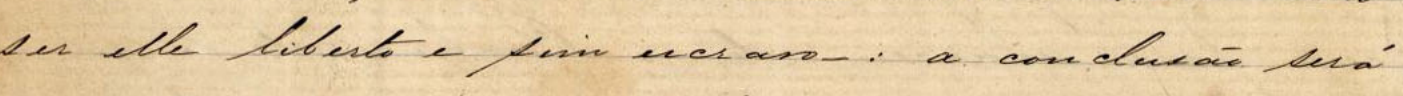

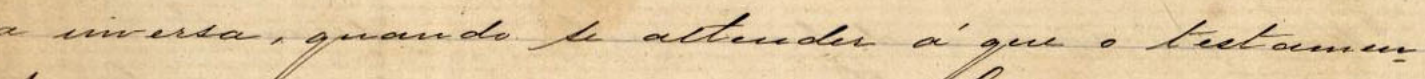
to de ged uya o de anenento de follt e' de lporg - Sevide obutor mascide e bafekeiodo we isory

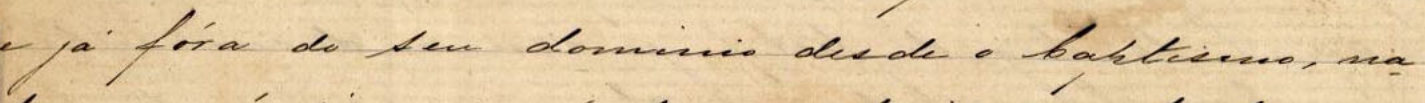

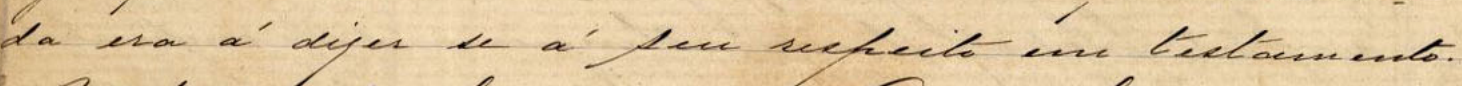

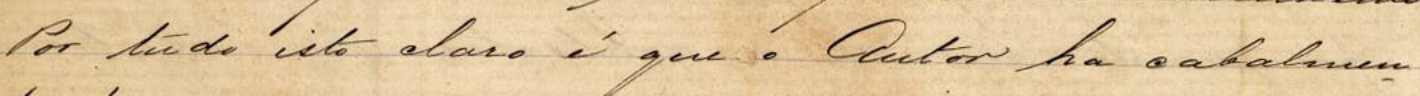

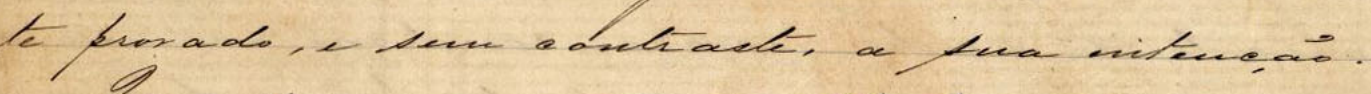

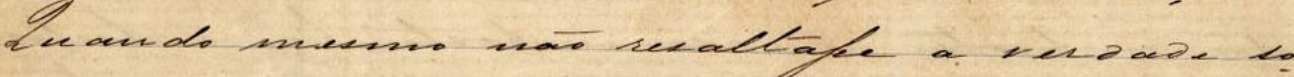

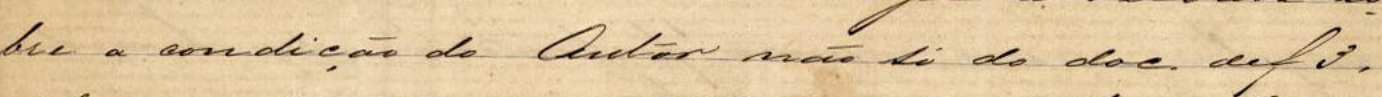

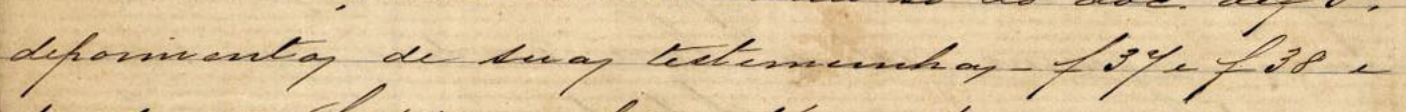

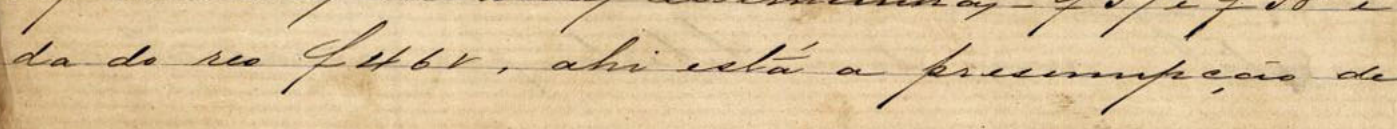


Fólio 69V

baptismo em diante; em nada vindo favorecer ao

Reo a declaração d'essas testemunhas que depoem terem tido sempre o Autor e sua mãe em (comta) de escravos- Não provando em contrario (á) 5 mente do Autor o documento de folhas 28, titulo de compra feita ultimamente por parte do Reo, o que aquelle não impugna, tanto que é com elle que ora contende; o documento de folhas 30verso em que se vê ter sido o Autor descripto entre os bens de Agueda Maria de Jesus, depois do fallecimento d'esta, por seu inventariante, pois é em razão d'esse injusto captiveiro que o Autor pleitêa a sua liberdade; e, finalmente, não logra o fim proposto o documento de folhas 31. Déste documento vê se que a primitiva proprietaria da mãe do Autor e d'elle até o baptismo, libertára aquella desde a data de seo fallecimento, ficando, porem, sujeitos ao captiveiro os filhos que della nascessem da occasião do testamento até essa épocha, e com nada declarase em relação ao Autor, conclue o Reo: - não ser elle liberto e sim escravo - : a conclusão será a inversa, quando se atender á que o testamento de que reza o documento de folhas 31 é de 1859 e sendo o Autor nascido e baptisado em 1854

e já fóra de seu dominio desde o baptismo, nada era a dizer se á seu respeito em testamento. Por tudo isto claro é que o Autor há cabalmente provado, e sem contraste, a sua intenção.

Quando mesmo não resaltasse a verdade sobre a condição do Autor não só do documento defolhas 3, depoimentos de suas testemunhas- folhas 37 e folhas 38 e da do reo folhas 46verso, ahi está a presumpção de 


\section{yo}

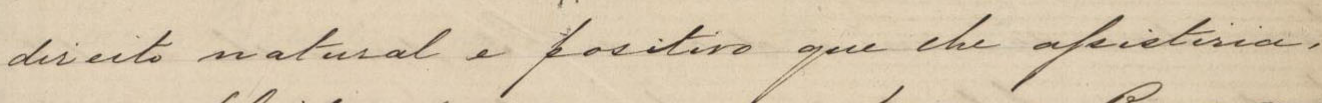

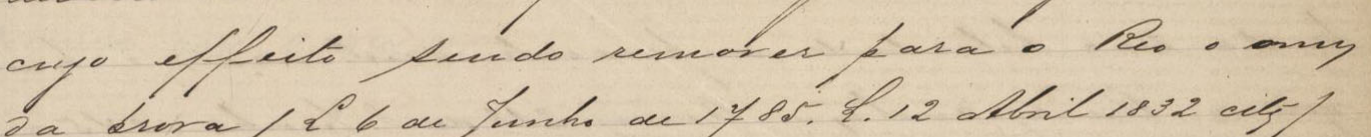

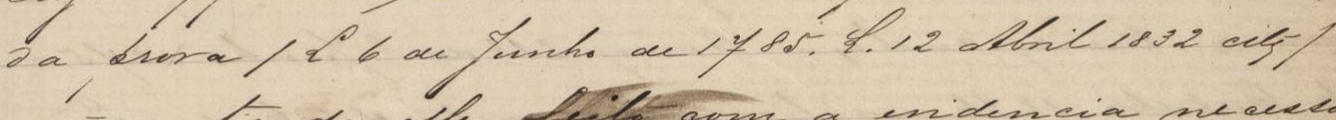

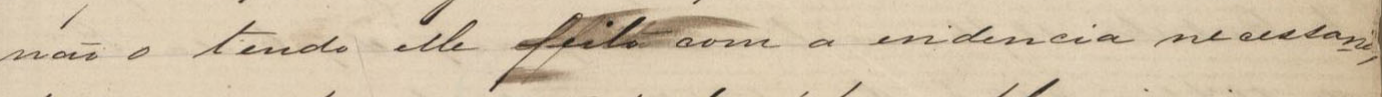
utaci, nat tevdo antraposto a' hesa

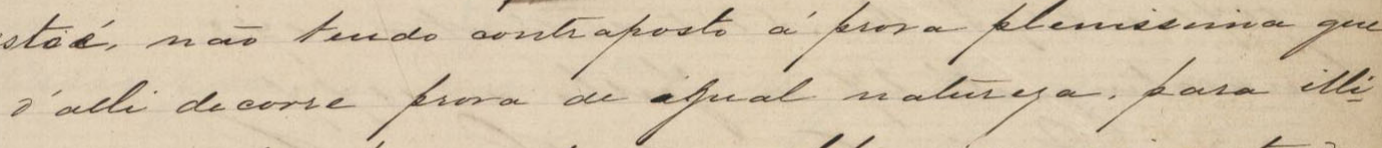

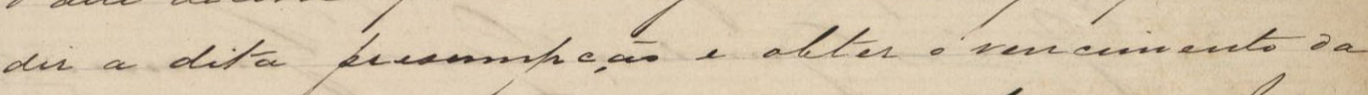

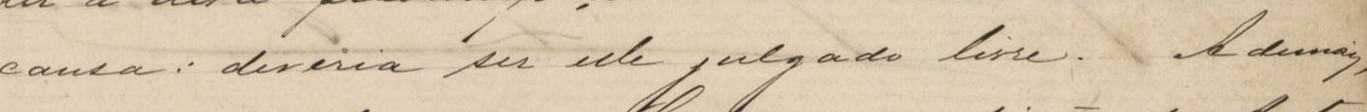

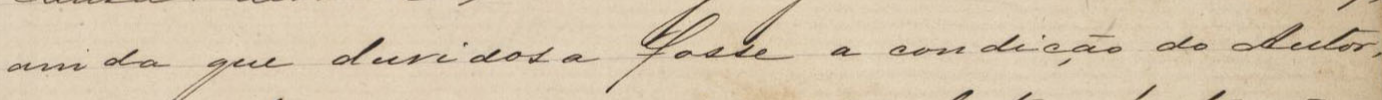
we the hia un tocconso - a kalutar érolece,aio

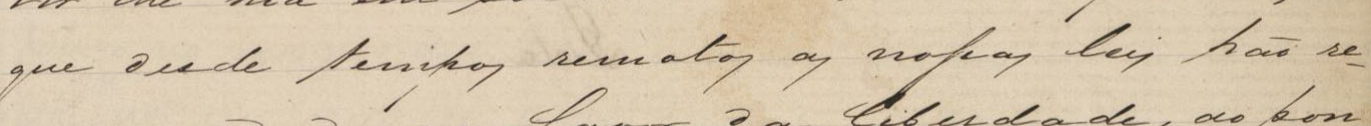
commentodo en favor o laberdade, do bon to de en hee beneficis tereno outaryadey

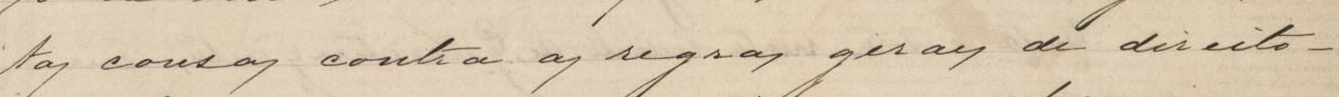

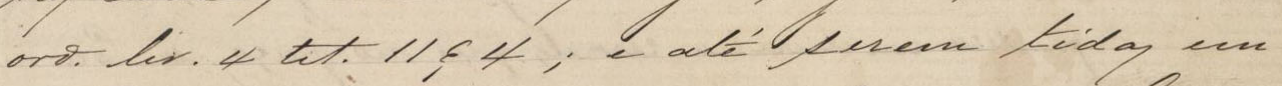

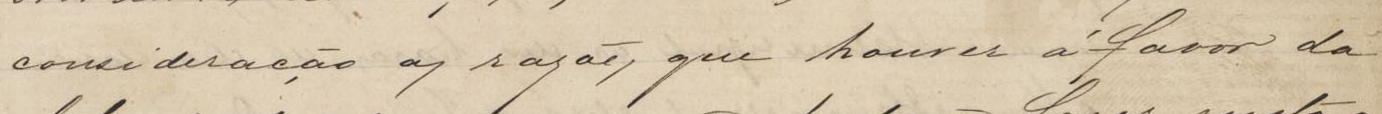
liberdade do gee a gew bodew fayes pecels.

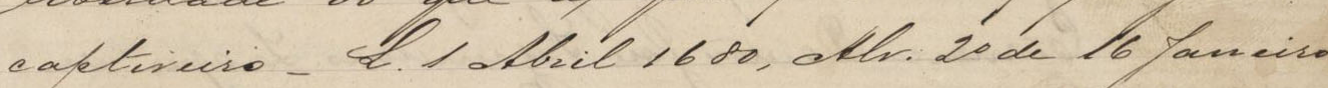

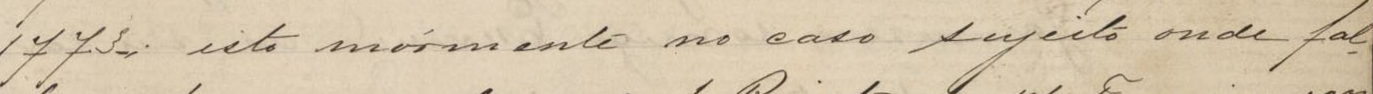

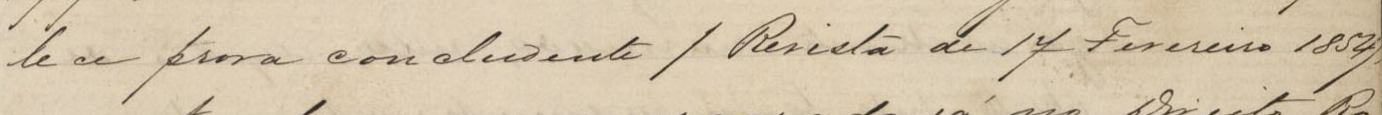

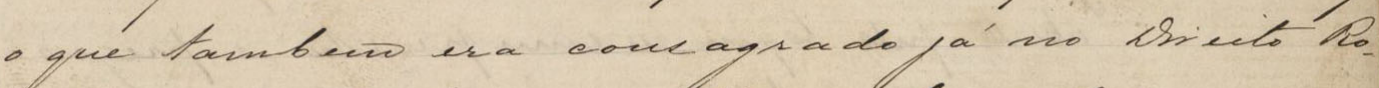

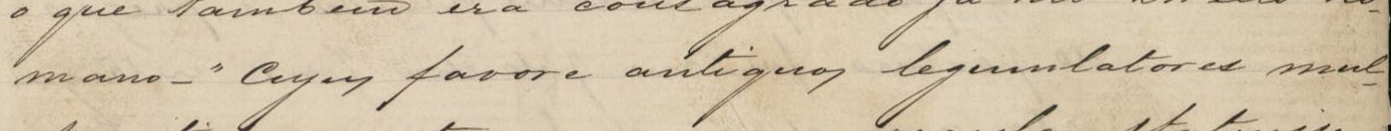

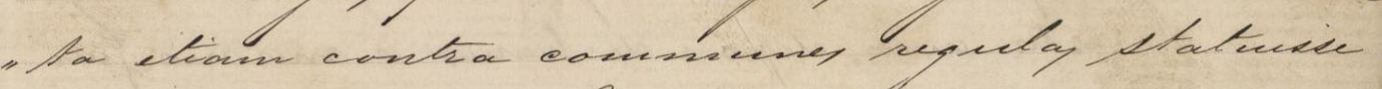

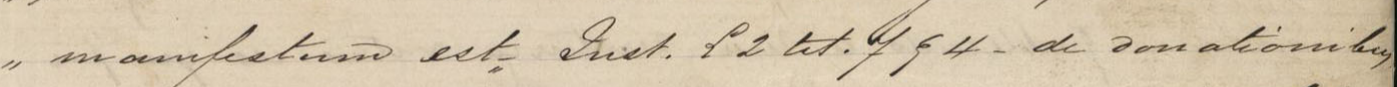

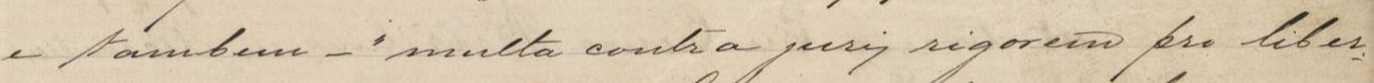

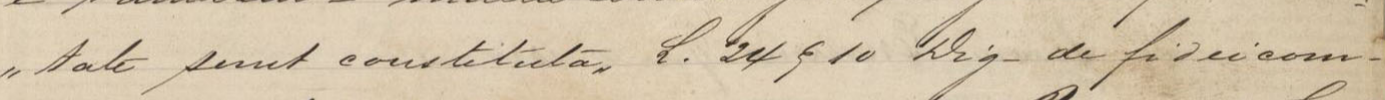

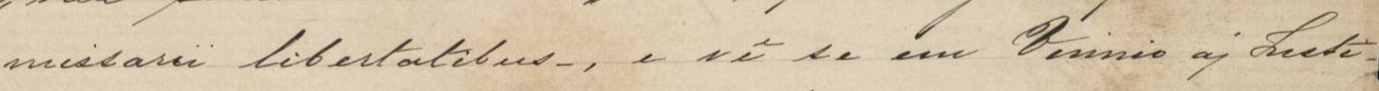

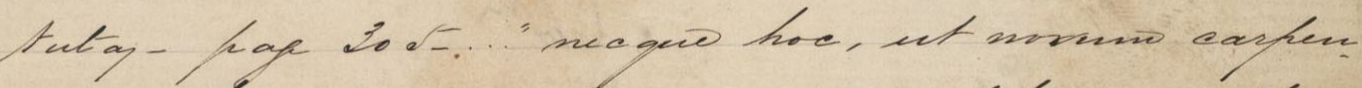

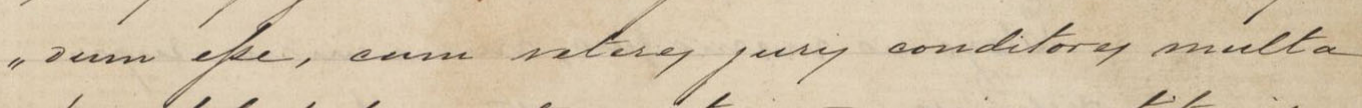

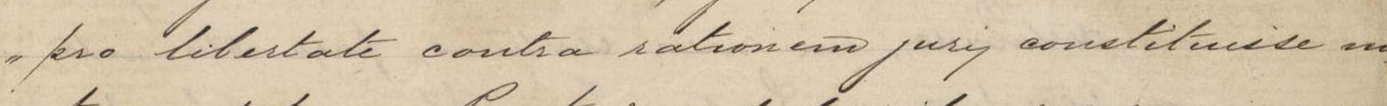

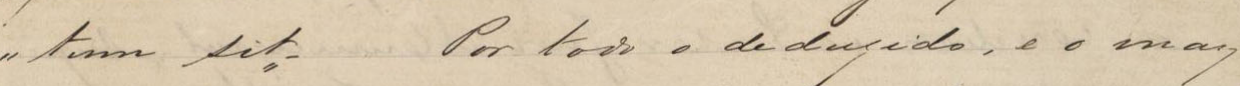

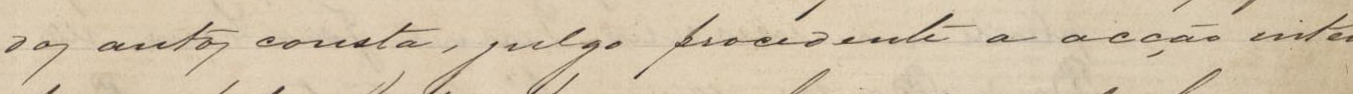

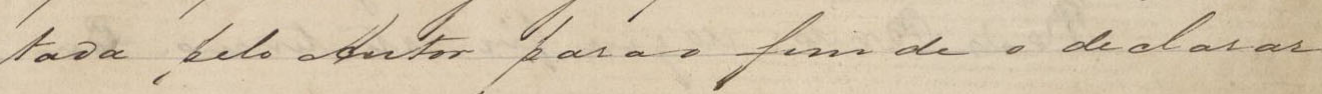


Fólio 70R

direito natural e positivo que lhe assitiria, cujo effeito sendo remover para o Reo o onus da prova/Lei 6 de Junho de 1785. Lei 12 de Abril de 1832 (ilegível)/ não o tendo elle feito com a evidencia necessaria,

5 isto é, não tendo contraposto á prova plenissima que

d'alli decorre prova de igual natureza, para illidir a dita presumpção e obter o vencimento da causa: deveria ser elle julgado livre. Ademais, ainda que duvidosa fosse a condição do Autor, vir lhe hia em socorro - a salutar protecção que desde tempos remotos as nossas leis hão recomendado em favor da liberdade, ao ponto de em seu beneficio serem outorgados muitas cousas contra as regras geraes de direitoordenaçoês Livro 4 titulo $11 \S 4$; e até serem tidas em mais consideração as razoẽs que houver á favor da liberdade do que as que podem fazer justo o captiveiro- Lei 1 de abril de 1680, (Als) $2^{\mathrm{O}}$ de 16 de Janeiro de 1773-; isto mormente no caso sujeito onde fallece prova concludente/ Revista de 17 de feveiro de 1854, o que também era consagrado já no direito Romano-"cujus favore antiguas (legimlatores) mul"ta etiam contra communes regulas statuisse "manifestum est-" Institutos $\S 2$ titulo $7 \S 4$ de donationibu e também - "multa contra juris rigorem pro liber"tate sunt constituta" Lei $24 \S 10$ (Dig)- de fideico"missaru libertatibus -, e vê se em(ilegível) as Institutas - pagina 305 - ..."necque hoc est (ilegível) carpen"dum esse, cum (veteres) juris conditores multa "pro libertate contra rationem juris constituisse no"tum sit ." Por todo o deduzido, e o mais que dos autos consta, julgo procedente a acção intentada pelo Autor para o fim de o declarar 


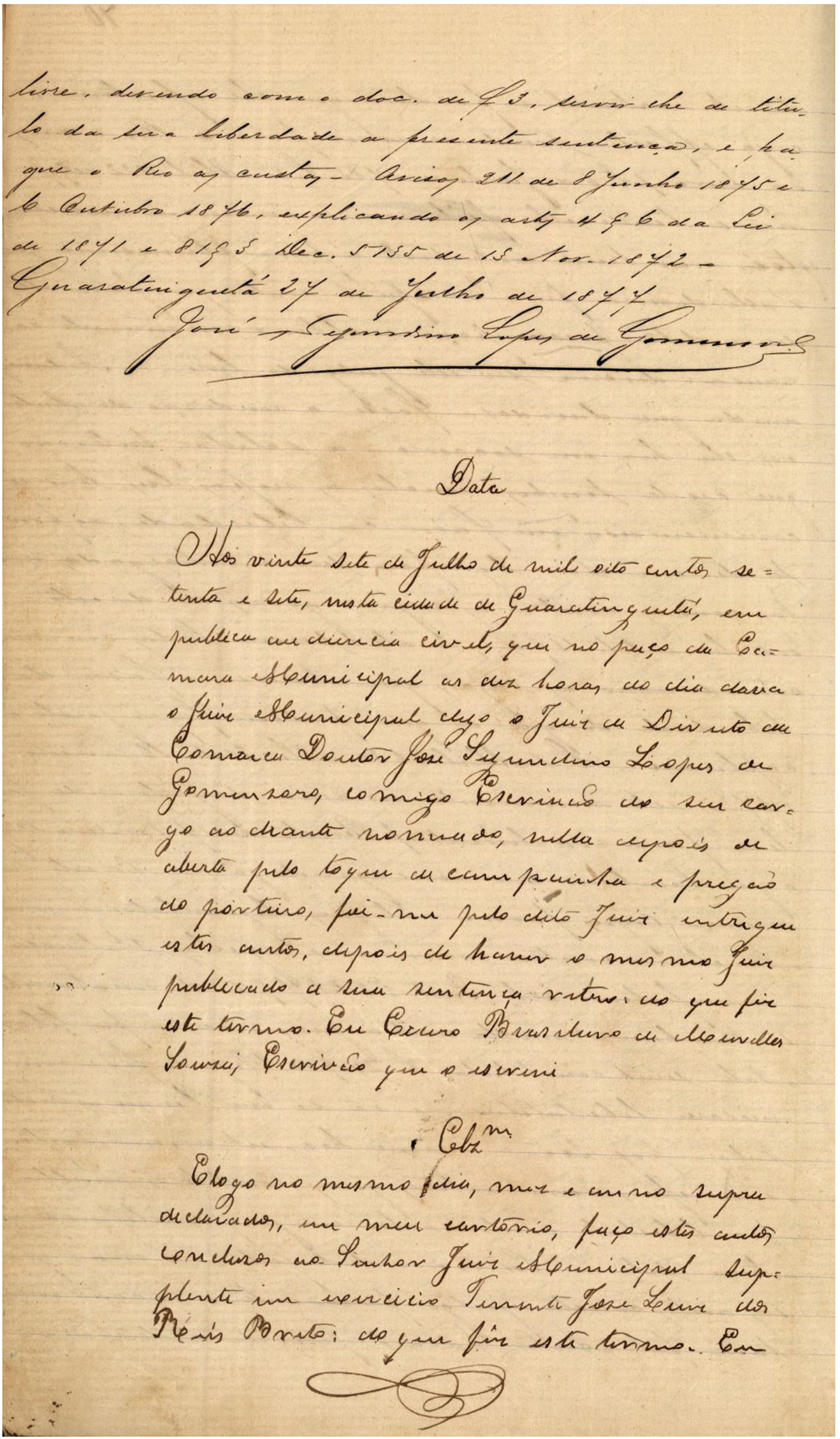


Fólio $70 \mathrm{~V}$

livre, devendo com o documento de folhas 3 servir lhe de titu-

lo da sua liberdade a presente sentença, e pa-

gue o Reo as custas. Avisos 211 de 8 de Junho de 1845 e

6 de Outubro de 1876, explicando os artigos $4 \S 6$ da Lei

5 de 1841 e $81 \S 3$ Decreto 5135 de 13 Novembro 1872.

Guaratinguetá 27 de julho de 1877

José Secondino Lopes de Gomensoro ${ }^{44}$

44 Este fólio possui, a seguir, anotações de terceiro, que não foram editadas. 


\subsection{DOC 14}

Documento: Acórdão (relatório e decisão)

Remetentes: juízes desembargadores representando a Justiça Estadual de São Paulo Tribunal da Relação $-2^{\mathrm{O}}$ grau

Local: São Paulo

Processo: $340 / 1877$

Destinatários:

Apelante: Padre Antonio Luis dos Reis França

Apelado: Pardo Antonio Leite dos Santos

Data: $1^{\text {O }}$ de março de 1878

Desembargador Relator: Joaquim Pedro Villaça (responsável pelo Relatório)

Descrição: 5 fólios - páginas 97 recto e verso, 98 recto e verso, 99 recto, sendo o relatório de um só punho, os votos pelos punhos dos respectivos desembargadores responsáveis, e a decisão pelo punho do desembargador Joaquim Pedro Villaça. Trata-se de uma ação de liberdade intentada por um escravo, que fora batizado como livre, entretanto, encontravase na condição de escravo. Sentença que julga procedente o pedido do autor, confirma a validade da certidão de batismo e o declara livre. Recorre o réu/apelado, tentando a reforma da sentença, que é negada. O recurso de apelação é julgado improvido e confirma a sentença de $1^{\circ}$ grau pelos mesmos motivos expostos nesta. 


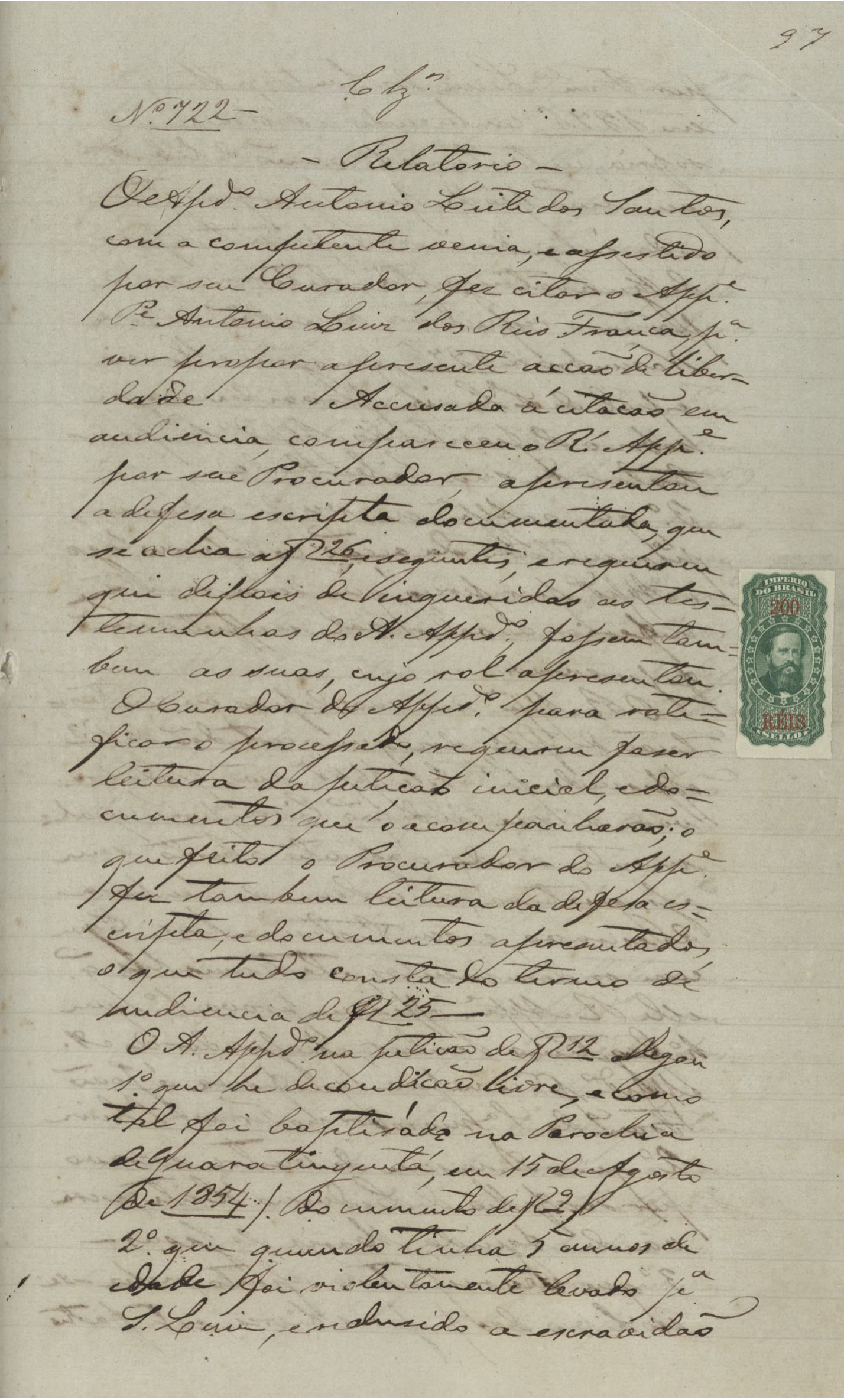


Fólio 97R

Número 722 - Relatorio -

O Apellado Antonio Leite dos Santos, com a competente venia, e assestido por seu Curador, fes citar o Appelante

5 Padre Antonio Luis dos Reis França, para ver propor apresente acçaõ de liberdade. Accusada a citaçaõ em audiencia, comparecem o Réu Appelante por seu Procurador apresentar

10 a defesa escripta documentada, que se acha a folhas 26 eseguintes, e requereu qui depois de inqueridas as testemunhas do Autor Appelado, fossem tambem as suas, cujo rol apresentou. O Curador do Appelado para ratificar o processado, requereu fazer leitura da petiçaõ inicial, edocumentos que acompanharaõ; o que feito o Procurador do Appellante fez tambem leitura da defesa escripta, e documentos apresentados, o que tudo consta do termo de audiencia de folhas 25 .

O Autor Appelado na petiçaõ de folhas 12 allegou

$251^{\mathrm{O}}$ que (he) de condiçaõ livre, e como tal foi baptisado na Parochia de Guaratinguetá, em 15 de Agosto de 1854/ documento de folhas 9 . $2^{\mathrm{O}}$ que quando tinha 5 annos de 30 edade foi violentamente levado para Saõ Luis, endusido a escravidaõ 


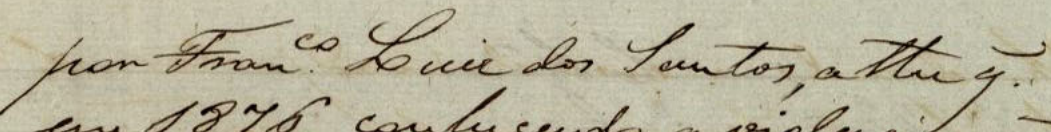

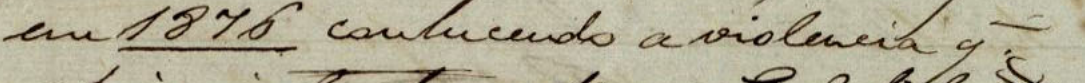

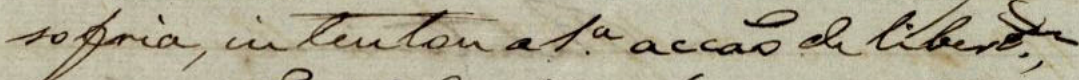

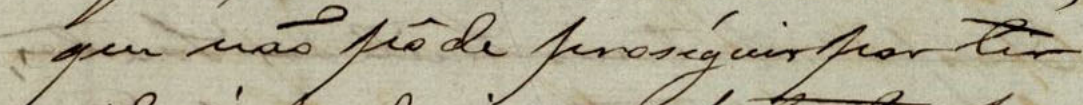

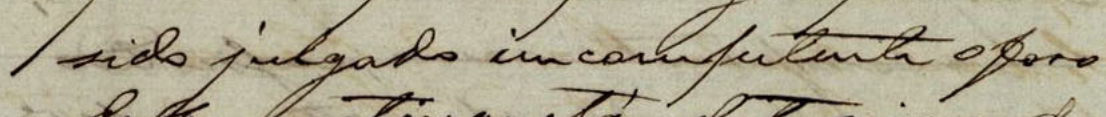

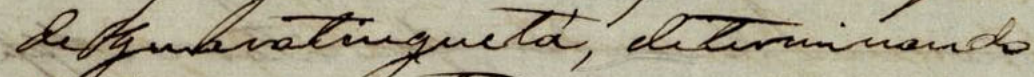

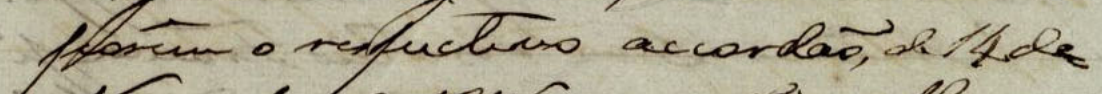

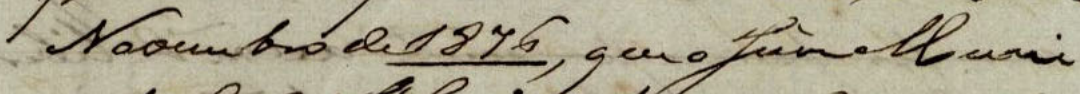

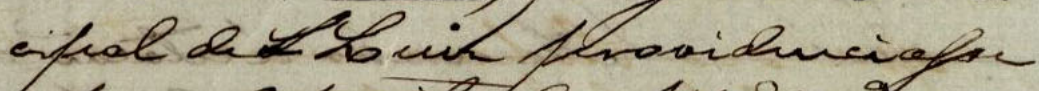

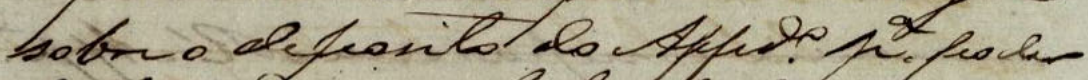
inalar de na Liberalade.

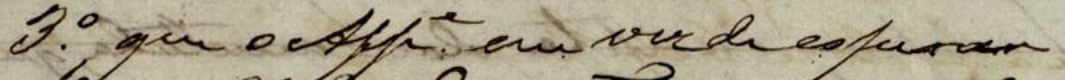

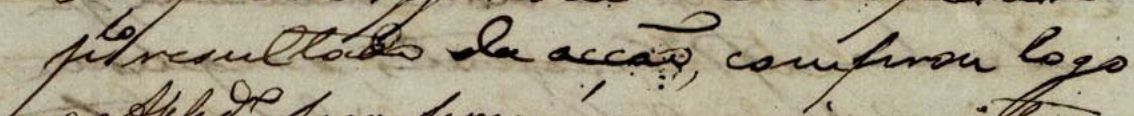

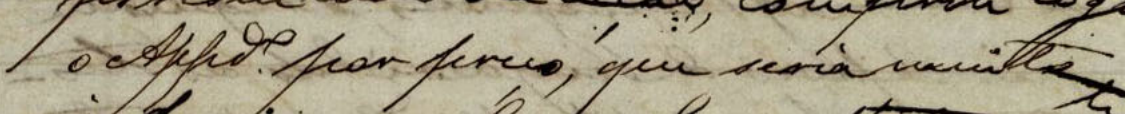

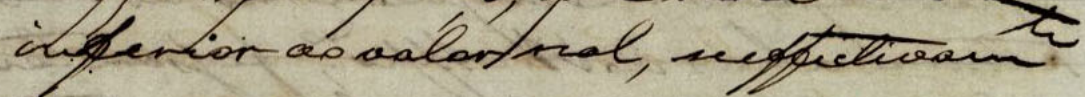

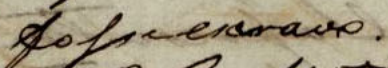

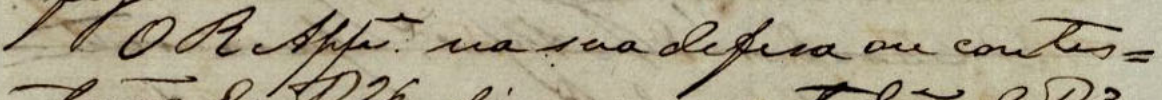

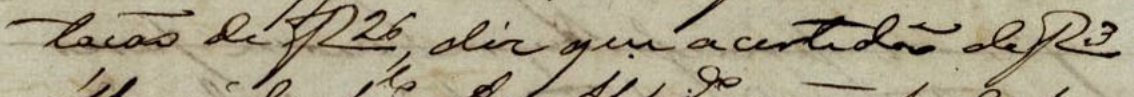

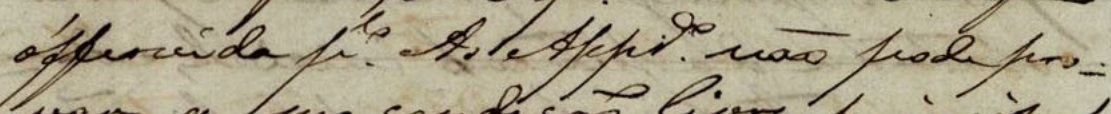

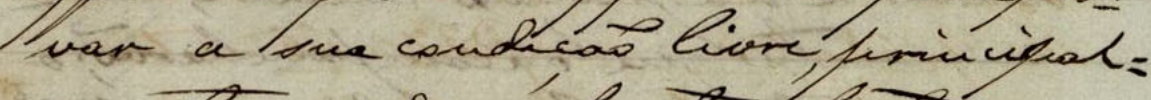

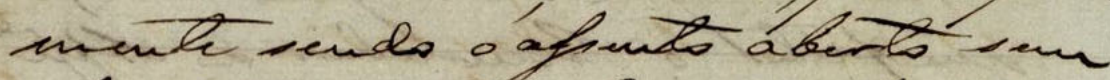

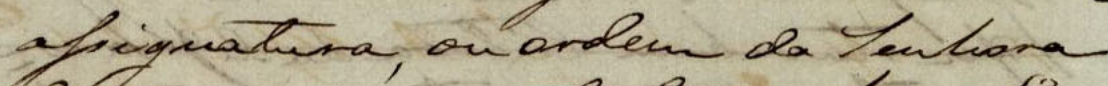

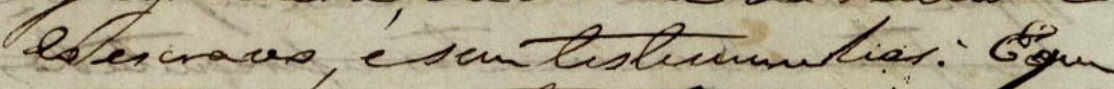

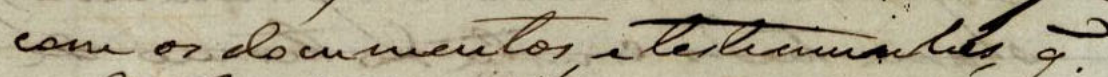

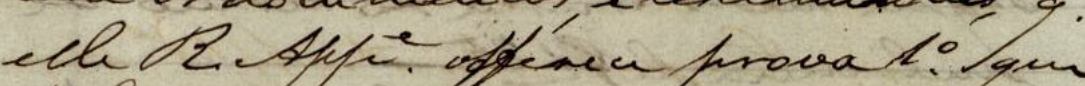

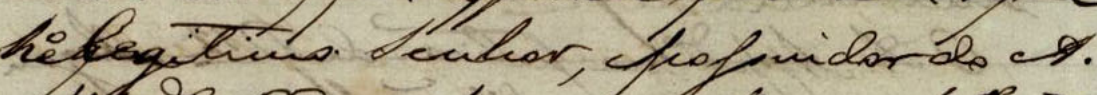

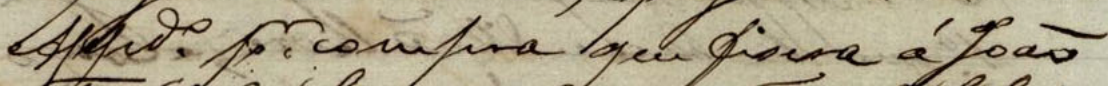

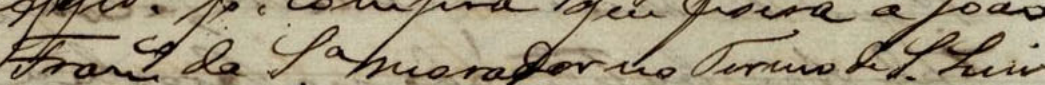

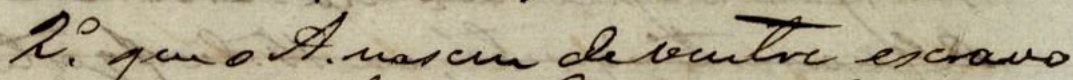

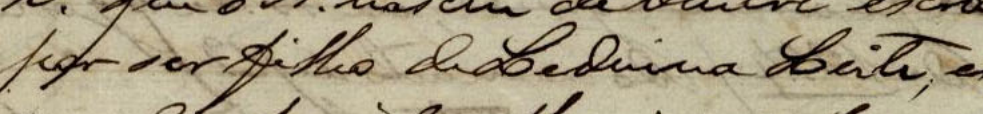

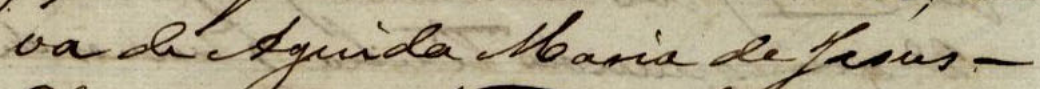

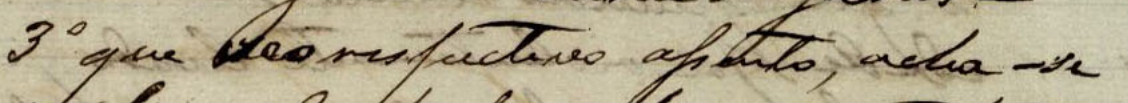

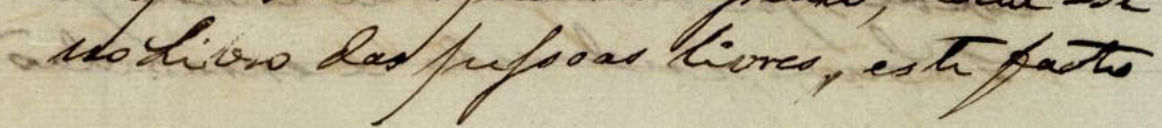


Fólio 97V

por Francisco Luiz dos Santos, atte que em 1876 conhecendo a violencia que sofria, intentou a primeira acçaõ de liberdade, que naõ pôde prosseguir por têr

5 sido julgado incompetente o foro de Guaratinguetá, determinando porêm o respectivo accordaõ, de 14 de Novembro de 1876, que o Juiz Municipal de Saõ Luis providenciasse sobre o deposito do Appellado para (ilegível) tratar de sua liberdade. $3^{\mathrm{o}}$ que o Appellante em vez de esperar pelo resultado da acçaõ comprou logo o Appellado por preço, que seria muito inferior ao valor real, seeffectivamenete fosse escravo.

O Réu Appellante na sua defesa ou contestaçaõ de folhas 26 , diz que a certidaõ de folhas 3 offerecida pelo Autor Appellado naõ pode provar a sua condiçaõ livre, principal= mente sendo o assento aberto sem assignatura, ou ordem da Senhora do escravo, e sem testemunhas. E que com os documentos, e testemunhas que elle Réu Appelante offereceu prova $1^{\underline{O}}$ que he legitimo Senhor, e possuidor do Autor Appellado pela compra que fizera à Joaõ Francisco da Silva morador no Termo de Saõ Luis. $2^{\mathrm{O}}$ que o Autor nasceu de ventre escravo por ser filho de Leduina Leite, escrava de Aguida Maria de Jesus $3^{\mathrm{o}}$ que seo respectivo assento, acha-se no Livro das pessoas livres, este facto 
DOC 14

203

Tr devide a emo do Coadjuctar th

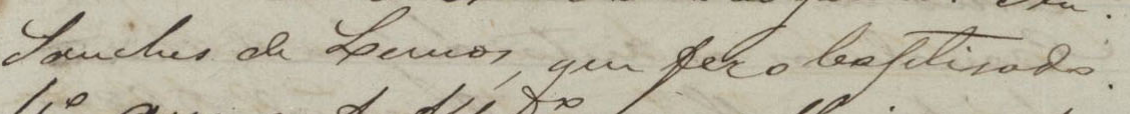
ti: que o At. Affíb, sua lbai venfine Ispas tido, liar escraves fear-vace Teutiona Itgaida Obaria de feoves: 5. quitharmarte Déla quidercinete

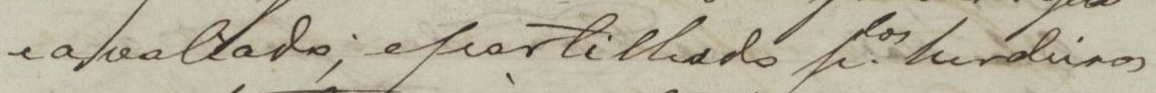
us nisfuchios civoutani -

6. que sua Senhana unea tive beu= nafo de liburlal-o, tanlo que em on tertamento, of eito en 23 devlllaiode1959, - a ber to a' 6 de funho do mescuo deno,

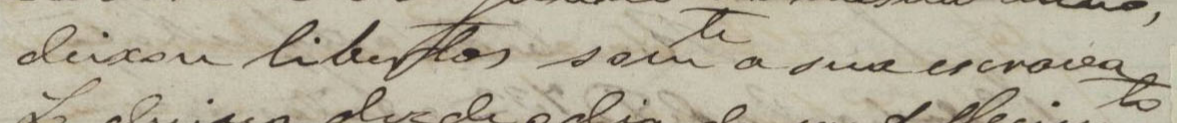

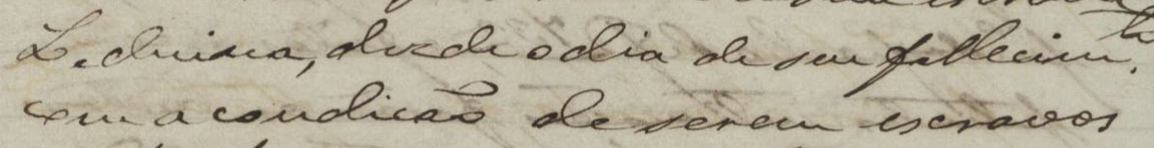

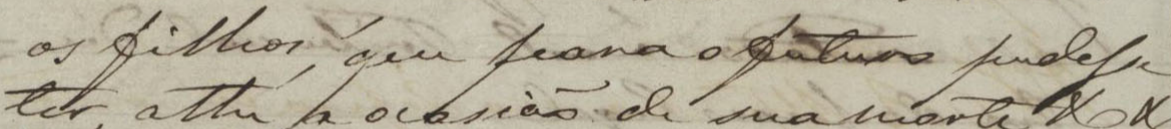

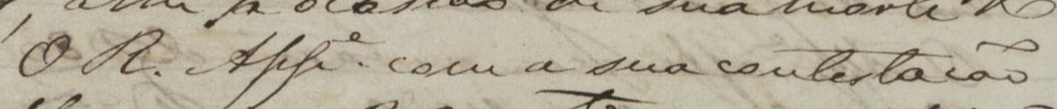

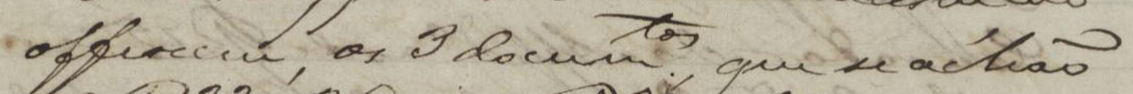

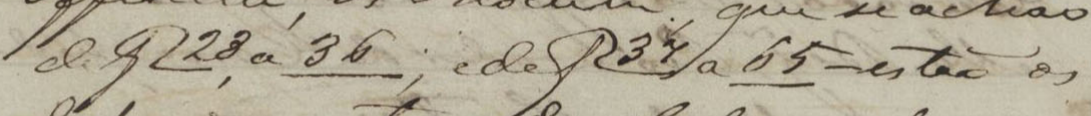

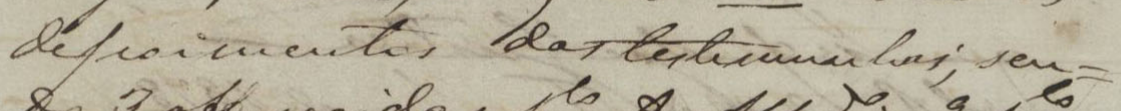

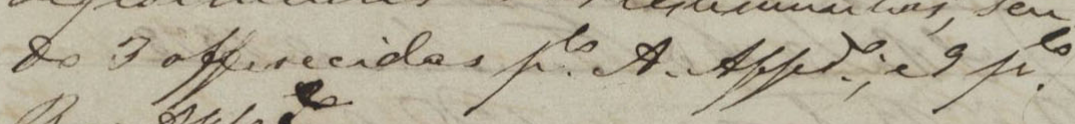
12. Osfine?

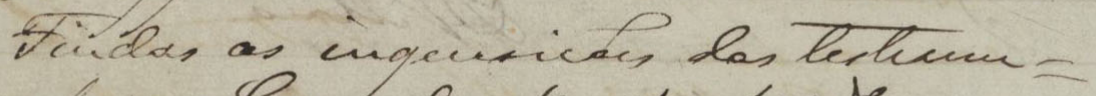

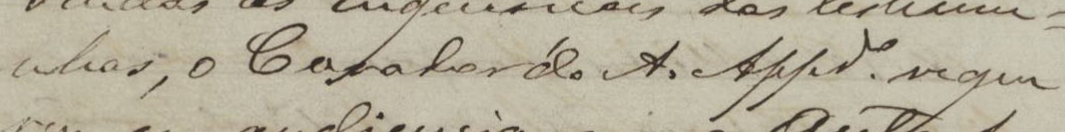
sur en andiencia que os Autbos tos: "cen conchires ab fuird Rirutes,

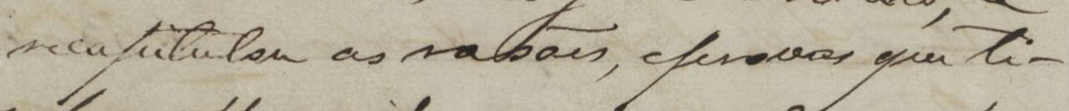
wha offerevids en favar di uafire-

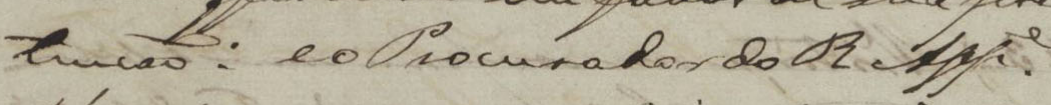

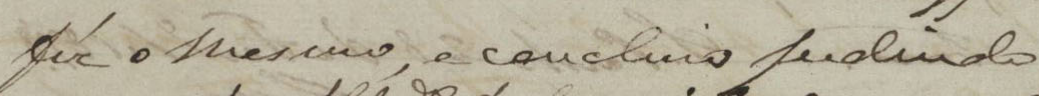

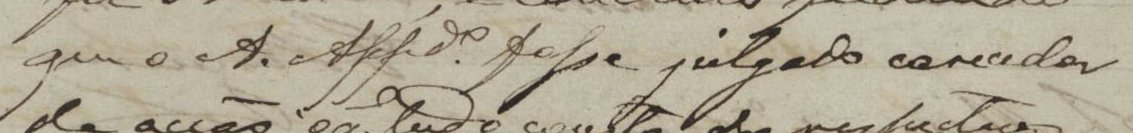

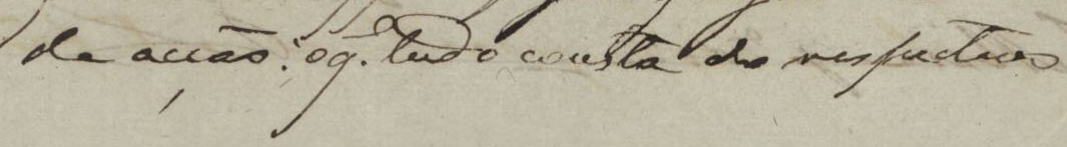


Fólio 98R

he devido a erro do Coadjuctor Antonio

Sanches de Lemos, que fez o baptisado.

$4^{\underline{O}}$ que o Autor Appellado, e sua Mai sempre

foraõ tidos por escravos por sua

5 Senhora Aguida Maria de Jesus.

$5^{\mathrm{o}}$ que por morte d'esta foi descripto

e avalidado; e partilhado pelos herdeiros

no respectivo inventario.

$6^{\mathrm{O}}$ que sua Senhora nunca teve ten-

10 çaõ de libertal-o, tanto que em seu

testamento, feito em 23 de Maio de 1859,

e aberto à 6 de Junho do mesmo anno,

deixou libertos somente a sua escrava

Leduina, desde o dia de seu fallecimento,

15 com a condiçaõ de serem escravos

os filhos, que para o futuro pudesse

ter, atte a ocasiaõ de sua morte.

O Réu Appellante com a sua contestaçaõ

offereceu, os 3 documentos que se achaõ

20

de folhas 23 a $\underline{36}$, e de folhas 37 a $\underline{65}$ - estaõ os

depoimentos das testemunhass, sen-

do 3 offerecidas pelo Autor Appellado; e 9 pelo

Réu Appellante.

Findas as inquisiçoẽs das testemu-

nhas, o Curador do Autor Appellado reque-

reu em audiencia que os Autos fos-

sem conclusos ao Juis de Direito, e

recapitulou as rasoẽs, (ilegível) que ti-

nha offerecido em favor de sua pre-

30

tençaõ: e o Procurador do Réu Appellante

fez o mesmo, e concluio pedindo

que o Autor Appellado fosse julgado carecedor

da acçaõ: o que tudo consta do respectivo 


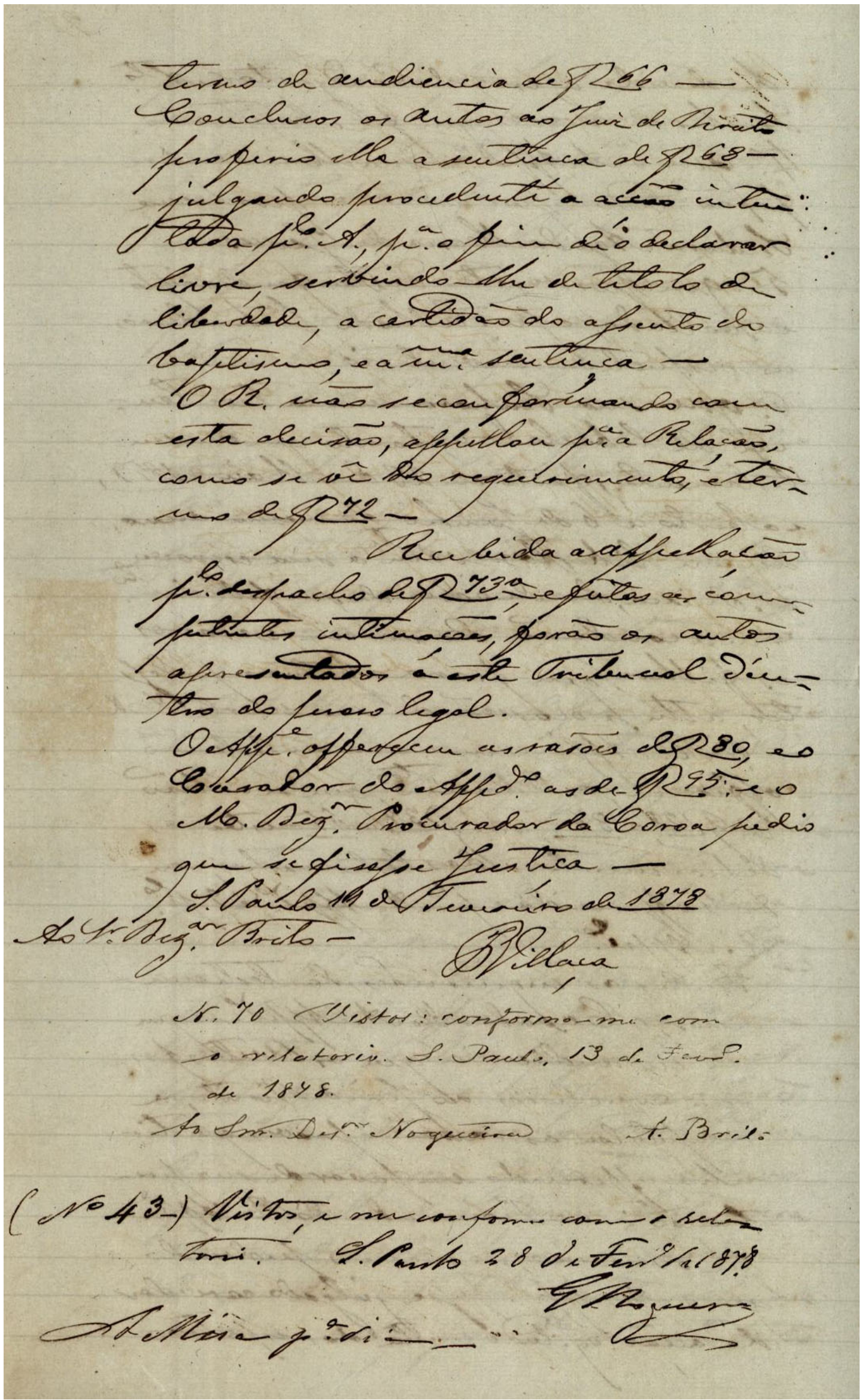


Fólio 98V

termo de audiencia de folhas66 -

Conclusos os autos ao Juis de Direito

proferio elle a sentença de folhas68 -

julgando procedente a acçaõ inten-

5 tada pelo Autor, para o fim de o declarar

livre, servindo-lhe de titolo de

liberdade, a certidaõ do assento do

baptismo, e a respectiva sentença -

O Réu naõ se conformando com

esta decisaõ, appellou para a Relaçaõ,

como se vê do requerimento, e ter-

mo de folhas 72

Recebida a appellaçaõ

pelo despacho de folhas73, e feitas as com-

15 petentes intimaçoẽs, foraõ os autos

apresentados a este Tribunal den-

tro do prazo legal.

O Appellante offereceu as rasoẽs de folhas80, e o

Curador do Appellado as de folhas95; e o

20 Ilustríssimo Dezembargador Procurador da Coroa pedio

que se fizesse Justiça.

Saõ Paulo 11 de Fevereiro de 1878.

Ao Senhor Dezembargador Brito -

\section{Joaquim Pedro Villaça}

Número 70 Vistos: conformo-me com

o relatorio. Saõ Paulo, 13 de Fevereiro

de 1878.

Ao Senhor Dezembargador Nogueira A. Brito

(número 43-) Vistos, e me conformo com o rela-

30 torio. Saõ Paulo, 28 de Fevereiro de 1878.

\section{Nogueira}

A mesa para dia 
DOC 14

207

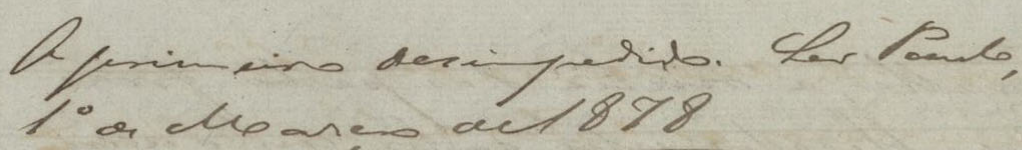

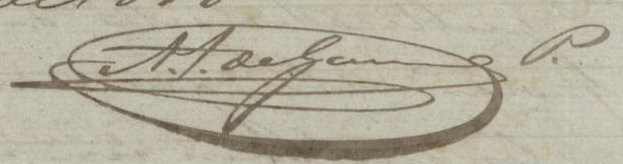

- Caminados, irelatados estes du tos, cutre fiantes Anpe Pe turtanio Levir dos Ris Iranica; Hefreo har do Antonio bute lós Santos: Accor = das en Rlacao; qui nequo frovi= manto a aféfidachos, ecolutinmar a oentenchal afféllada froryue seas Aundámethos sás firocidantése conformes com oden conta das untas. I. Sunlo tide Hearco detsys

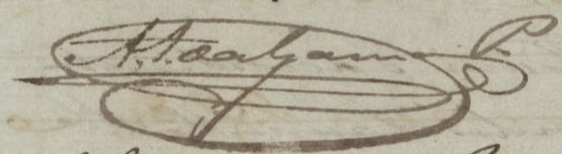

Jeirnte. Y Pank,
8 de tharc, de $18 \% 8$
Jarir

Bplelecua

99 
Fólio 99R 45

Examinados, e relatados estes au-

tos, entre partes Appelante Padre Antonio

Luiz dos Reis França; e Appellado o par-

do Antonio Leite dos Santos: accor-

5 daõ em Relaçaõ; que negaõ provi-

mento a appellaçaõ e confirmaõ a

sentença appellada, porque seos

fundamentos saõ procedentes e

conformes com o que consta dos

10 autos: e condenaõ o Appelante nas

custas. Sa õ Paulo $1^{0}$ de Março de 1878

Agostinho Luiz da Gama

Joaquim Pedro Villaça ${ }^{46}$

Frederico Augusto Brito

15 Nogueira

45 Este fólio possui, em sua parte inicial, anotações de terceiro, que não foram editadas; possui também, na lateral e na transversal, um selo.

46 Este fólio possui, nesta mesma linha, anotações de terceiro, que não foram editadas. 


\section{Capítulo 5}

\section{As vozes no discurso decisório}

\subsection{Introdução}

Neste capítulo, realizaremos a análise das quatorze decisões produzidas pelo poder judiciário, objetos dessa dissertação, em primeiro e segundo grau, sendo sete sentenças proferidas por juízes da Relação, diretamente das Comarcas localizadas dentro do Estado de São Paulo, nas quais o processo tramitou, e também sete acórdãos, proferidos por juízes desembargadores do Tribunal da Relação do Estado de São Paulo, como órgão superior.

Utilizaremos, para a análise, a numeração dos fólios estabelecida no Capítulo 4. Para viabilizarmos o estudo e tecermos as comparações entre os julgados, faremos, primeiramente, a identificação da presença dos outros em cada decisão, na forma de quadros. Prosseguindo, realizaremos um levantamento das estratégias linguísticas utilizadas por cada juiz para trazer estas vozes, e as consequentes vozes por estes recursos reveladas. Dentre as estratégias linguísticas, destacamos os discursos citados e os respectivos introdutores utilizados para marcar a presença do outro, de maneira a refletir como estes juízes (na posição de autores de seus discursos) realizam estas presenças para compor o sentido a ser dado à decisão, configurando, assim, os outros da relação dialógica. Esses quadros conterão um levantamento de forma analítica, das marcas linguísticas, em cada parte da decisão (Relatório, Fundamentação e Decisão), para então, a partir deste levantamento de 
categorias, fazermos as consequentes interpretações de todas as sentenças, comparativamente, depois todos os acórdãos, da mesma forma e, por fim, cruzarmos as informações das sentenças com os seus respectivos acórdãos. Assim será possível estabelecermos um diálogo entre textos de autores diferentes, em gêneros diferentes (sentenças x acórdãos) e entre mesmos textos (sentenças e acórdãos) de autores diferentes, para então, a partir da interpretação, refletirmos como os autores (juízes) destes discursos manejam as vozes ou discursos para garantirem o alcançe do sentido por eles almejado, perfazendo um discurso dialogicamente construído, na continuidade da cadeia de enunciados que culminam nas suas decisões.

Sendo assim, na seção 5.1.1, por intermédio de quadros-resumo, faremos um levantamento objetivo dos outros presentes nos discursos, com a identificação da presença seguida, em paralelo, com um momento da decisão em que este outro aparece ou com a sua forma de aparição no documento. Nesta mesma seção, ainda como parte da análise, faremos um outro corte, trazendo uma segunda etapa de quadros-resumo, entretanto, nesses, identificaremos as estratégias (discursos indiretos, diretos e em modalização segunda) utilizadas pelos magistrados para trazer os outros relacionados naqueles primeiros quadros-resumo, juntamente com a sinalização dos trechos dos discursos nos quais estas estratégias são utilizadas. Finalmente, as seções 5.1.2 e 5.1.3, a partir das categorias levantadas, perfará a função interpretativa destas estratégias, constituindo o momento crucial deste estudo, ou seja, será o momento de responder, com as análises, a questão norteadora deste estudo. 


\subsection{Análise e interpretação das decisões}

\subsubsection{As outras presenças}

Iniciamos retomando, mais uma vez, a grande questão norteadora deste estudo: a produção do discurso decisório resulta em decisões pautadas exclusivamente na lei, sem qualquer inclinação ideológica do julgador, ou, ao contrário, estas decisões refletem discursos influenciados e permeados por outros discursos, representando as vozes que compõem estes discursos dialógicos? Voltemos também ao contexto de produção destas decisões, ressaltando o período no qual a visão positivista do direito predominava, devendo o juiz ser mero aplicador da lei, no momento da realização do direito, no momento da decisão.

No viés positivista, o juiz era mero instrumento a serviço do dever-ser da norma. Imperava a crença na neutralidade, as decisões como sequência lógica do binômio lei x aplicação, como um ato totalmente racional e livre de qualquer influência ou interpretação da pessoa, do ser, do juiz. Este era, de forma resumida, e também como já vimos nos capítulos anteriores, a filosofia da época. Época esta que também nos remete aos grandes discursos de liberdade, em oposição à escravidão até então dominante dentro do sistema econômico. Fervilhavam anseios pela libertação, ouviam-se gritos de indignação à condição destes nossos autores processuais, em correspondência com os ideiais já espalhados pelo mundo, por outras potências econômicas. Entretanto, simultaneamente, ideias conservadoras a defender a manutenção do sistema escravista, sugeridas nas decisões de improcedência, aqui analisadas. E tudo isso nos trazem os discursos: todas essas vozes, todo esse diálogo com o "mundo", de maneira a contrariar amplamente a visão filosófica que as geraram, de maneira a confirmar e a salientar o novo pensar, o dialogismo a constituir todo e qualquer falar.

Desta feita, melhor maneira de começar não há: o levantamento dos outros presentes nestes documentos. Os juízes, na posição de autores de seus discursos, trazem a compor a 
teia discursiva as outras vozes, de outros atores processuais. Dão voz ao autor, trazendo suas alegações, fazem ouvir o réu, narrando suas argumentações, comprovam suas razões norteadoras com as vozes de testumunhas dos autos, peritos, lei, doutrina, outras decisões. Por isso, cabe aqui, de antemão, os quadros-resumo com o levantamento destas outras presenças, de forma que tenhamos um panorama geral destas teias discursivas, seguidos dos levantamentos das estratégias utilizadas para dar voz a estes outros (na segunda lista de quadros).

Quadros-resumo: Identificação dos "outros".

\begin{tabular}{|c|c|c|}
\hline D1S1 & $\begin{array}{l}\text { autor } \\
\text { réu } \\
\text { autoridade (jurisprudência) } \\
\text { doutrina } \\
\text { princípios de direito } \\
\text { lei } \\
\text { documentos }\end{array}$ & 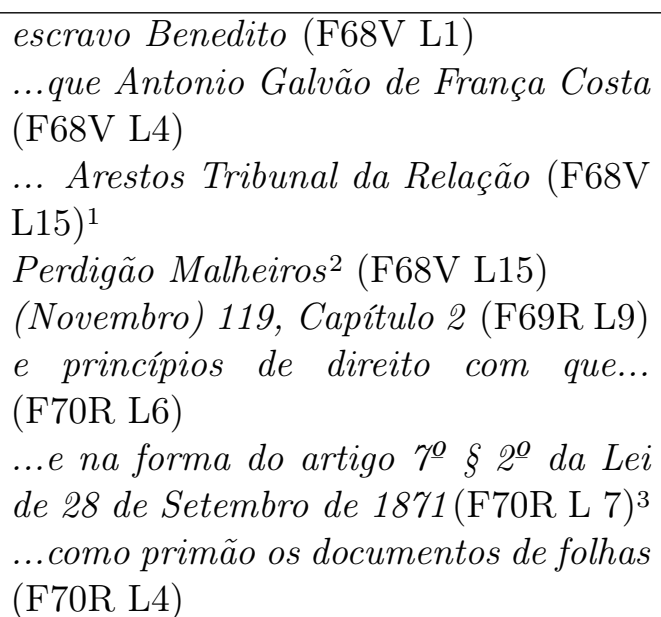 \\
\hline
\end{tabular}

\footnotetext{
${ }^{1}$ Arestos são as decisões do Tribunal da Relação, o que chamamos atualmente de "julgados", ou seja, equivalentes às decisões dos Tribunais modernos.

${ }^{2}$ São as as doutrinas, comumente citadas, da mesma forma, nas decisões atuais.

${ }^{3} \mathrm{Em}$ quase todos os julgados aparecerão citações de lei, doutrina, outros julgados, a embasar as decisões. Entendemos aqui estas citações como voz de autoridade, a legitimar a fundamentação do juiz. Em algumas vezes, elas virão citadas pela estratégia do discurso em modalização segunda, com a conjunção introdutora deste tipo de discurso. Em outros casos, esta conjunção não aparece expressamente, mas o valor do enunciado se equipara ao discurso de modalização segunda, considerando que a conjunção está implícita.

${ }^{4} \mathrm{O}$ discurso autoritário (de autoridade) exige nosso reconhecimento incondicional, e não absolutamente uma compreensão e assimilação livre em nossas próprias palavras. Também não permite qualquer jogo com o contexto que a enquadra, ou com seus limites, quaisquer comutações graduais ou móveis, variações livres e criativas e estilizantes. Ela entra em nossa consciência verbal como uma massa compacta e indivisível, é preciso confirmá-la inteiro ou recusá-la na íntegra. Ela se incorpora indissoluvelmente à autoridade - o poder político, a instituição, a personalidade - com ela permanece e com ela cai (Bakhtin, 1975/1998: 144).
} 


\begin{tabular}{|c|c|c|}
\hline D2A1 & $\begin{array}{l}\text { apelante } \\
\text { apelado } \\
\text { autoridade (doutrina) } \\
\text { curador } \\
\text { documentos }\end{array}$ & $\begin{array}{l}\text { escravo Benedito - ...allegou o liber- } \\
\text { tando.. (escravo que pedia a liberdade) } \\
\text { (F76V L9) } \\
\text { Antonio Galvão de França Costa - O } \\
\text { reo contraria a folhas } 28 \text { e dis... (F77R } \\
\text { L22) } \\
\text { Coelho da Rocha Direito Civil 109... } \\
\text { (F90R L14) } \\
\ldots \text {..o Curador replicou por negação... } \\
\text { (F77V L2) } \\
\text {...allegou que em vista dos documentos } \\
\text { folhas } 3 \text { e } 22 . . . \text { (F90R L4) }\end{array}$ \\
\hline
\end{tabular}

\begin{tabular}{|c|c|c|}
\hline$\overline{\mathrm{D} 3 \mathrm{~S} 2}$ & $\begin{array}{l}\text { autora } \\
\text { réu } \\
\text { doador da mãe da autora } \\
\text { autoridade (lei) } \\
\text { autoridade (jurisprudência) } \\
\text { doutrina }\end{array}$ & $\begin{array}{l}\text { Emiliana parda - ... como autora por } \\
\text { seu curador a parda Emiliana... (F32R } \\
\text { L2) } \\
\text { Antonio Teixeira de Carvalho - ...por } \\
\text { parte do Reu... (F32V L1) } \\
\text {..Direito Romano na Lei } 1^{o} \text { Codigo } \\
\text { Commercial de manumissão (F32V } \\
\text { L20) } \\
\text {...de conformidade com a Lei de } 19 \text { de } \\
\text { Agosto de } 1769 \ldots \text { (F32V L26) } \\
\ldots \text { Arestos Lei 4 Titulo } 11 \S 4^{o} \ldots \text { (F33R } \\
\text { L39) } \\
\text {..A escravidão no Brazil - do Doutor } \\
\text { Perdigaõ... (F33R L32) }\end{array}$ \\
\hline
\end{tabular}

\begin{tabular}{|c|c|c|}
\hline $\mathrm{D} 4 \mathrm{~A} 2$ & $\begin{array}{l}\text { autora } \\
\text { réu } \\
\text { documentos } \\
\text { legítimo senhor de Jacinta } \\
\text { (doador) }\end{array}$ & $\begin{array}{l}\text { Emiliana } \\
\text {..em contestação appos o réo... (F51R } \\
\mathrm{L} 24) \\
\text {...constantes do documento em original } \\
\text { a folhas } 26 \ldots \text { (F50V L14); } \\
\text {...segundo os documentos que se apre- } \\
\text { zenta a folhas } 7,8 \text { e } 26 \ldots \text { (F51RL6) } \\
\text {...servirá por espaço de tempo de } 27 \text { an- } \\
\text { nos... (F51R L14) }\end{array}$ \\
\hline
\end{tabular}




\begin{tabular}{|c|c|c|}
\hline D5S3 & $\begin{array}{l}\text { autor } \\
\text { réu } \\
\text { autoridade (lei) } \\
\text { testemunha } \\
\text { autoridade (jurisprudência) } \\
\text { autoridade (lei) } \\
\text { todo o processo }\end{array}$ & $\begin{array}{l}\text { José Africano } \\
\text { Luís Antonio Lopes da Silva } \\
\text { Lei de } 7 \text { de Novembro de } 1831 \\
\text { do autor: folhas } 14,17,19 \text { e } 34 \text {; do réu: } \\
\text { folhas } 21 \text { e } 22 \\
\text { arestos dos Tribunais Superiores; } \\
\text { Juiz Marechal da } 2^{\mathrm{a}} \text { Vara da Corte; } \\
\text { Dois Acórdãos da Relação } \\
\text { Lei de } 28 \text { de setembro de } 1871 \text {, artigo } \\
7^{\text {O}} \S 2^{\mathrm{O}} \text { e artigo } 80 \S 2^{\mathrm{O}} 4 \\
\ldots e \text { outras que dos autos constaõ... } \\
\text { (F42R L27) }\end{array}$ \\
\hline
\end{tabular}

\begin{tabular}{|c|c|c|}
\hline D6A3 & $\begin{array}{l}\text { autor } \\
\text { curador do autor } \\
\text { defensor do réu } \\
\text { testemunhas } \\
\text { juiz de direito } \\
\text { autoridade (lei) } \\
\text { sentença } \\
\text { todo o processo }\end{array}$ & $\begin{array}{l}\text { Pardo José } \\
\text { advogado do Tribunal, Doutor Augusto } \\
\text { de Camargo; } \\
\text { advogado Doutor Braulio; } \\
\text { testemunhas do autor; } \\
\text { testemunhas do réu } \\
\text { magistrado da sentença } \\
\text { disposição do artigo } 81 \S^{0} \text { do Regi- } \\
\text { mento número } 5135 \text { de } 13 \text { de novembro } \\
\text { de } 1872 ; \\
\text { Lei de } 7 \text { de Novembro de } 1831 \\
\text { todos os fundamentos da sentença; } \\
\text { direito e provas dos autos; }\end{array}$ \\
\hline
\end{tabular}

\begin{tabular}{|c|c|c|}
\hline$\overline{\mathrm{D} 7 \mathrm{~S} 4}$ & $\begin{array}{l}\text { autores } \\
\text { réus } \\
\text { testemunhas } \\
\text { documentos } \\
\text { autoridade (jurisprudência) }\end{array}$ & $\begin{array}{l}\text { Benedicto, Porcina, Guerino, Rosa e } \\
\text { João (por seu curador) } \\
\text { espólio da finada Dona Teodora - ... } \\
\text { defendem-se os Reos em suas... (F84V } \\
\text { L16) } \\
\text { depoimentos das testemunhas; } \\
\text { informantes; } \\
\text { testemunha José Francisco de Toledo; } \\
\text { as testemunhas Anna Antonio de To- } \\
\text { ledo, Luis Antonio Dias de Azevedo, } \\
\text { Luis Francisco Soares e Francisco An- } \\
\text { tonio Monteiro; } \\
\text { as testemunhas Antonio Lourenço de } \\
\text { Oliveira e Luisa Maria da Conceição; } \\
\text { documento de folhas 57; } \\
\text { Relação da Corte na apelação número } \\
\text { 13953 }\end{array}$ \\
\hline
\end{tabular}




\begin{tabular}{|c|c|c|}
\hline D8A4 & $\begin{array}{l}\text { apelantes } \\
\text { apelados } \\
\text { o juiz da sentença } \\
\text { todo o processo }\end{array}$ & $\begin{array}{l}\text { Espólio da finada Dona Teodora } \\
\text { Guerino e outros - ... Os autores Appel- } \\
\text { lados... (F91R L1) } \\
\text {...o juiz de direito respectivo na sen- } \\
\text { tença de folhas } 55 . . \text { (F91V L17) } \\
\text {...conforme a direito e as provas dos au- } \\
\text { tos... (F92R L13) }\end{array}$ \\
\hline D9S5 & $\begin{array}{l}\text { autor } \\
\text { autoridade (lei) } \\
\text { juiz } \\
\text { curador destituído } \\
\text { autoridade (legislação e dou- } \\
\text { trina) }\end{array}$ & $\begin{array}{l}\text {... O preto Miguel pedio... (F88V L1) } \\
\text { Lei de } 7 \text { de Novembro de } 1831 \\
\text { Supplente do Juiz Municipal } \\
\text { Gonçalves } \\
\text { Lei } 1^{\mathrm{a}} \text { in prime; } \\
\S 9^{0} \text { Digesto inti possio; } \\
\text { Ordenamento Livro } 3 \text { titulo } 48 \text { e titulo } \\
78 \S 5 ; \\
\text { Consolidação das Leis Civis }\end{array}$ \\
\hline D10A5 & $\begin{array}{l}\text { apelante } \\
\text { apelado } \\
\text { curador de Miguel } \\
\text { juiz } \\
\text { sentença } \\
\text { autoridade (lei) }\end{array}$ & $\begin{array}{l}\text { preto Miguel } \\
\text { Casemiro dos Santos Pinto } \\
\text { Gonçalves } \\
\text { juiz municipal suplente; juiz de direito } \\
\text { sentença apelada e seus fundamentos } \\
\text { artigo } 80 \text { do Regulamento de } 13 \text { de No- } \\
\text { vembro de } 1872 \text {; } \\
\text { Regulamento de } 22 \text { de Novembro de } \\
1871 \text { artigo } 55 \text {; } \\
\text { Decreto de } 12 \text { de Abril de } 1832 \text { artigo } \\
9^{\mathbf{0}}\end{array}$ \\
\hline D11S6 & $\begin{array}{l}\text { autores } \\
\text { autoridade (doutrina) }\end{array}$ & $\begin{array}{l}\text {...entre partes como justificantes } \\
\text { Raphael Antonio Evaristo, Jeremias } \\
\text { Pedro Gonçalves (F40V L2) } \\
\text { praxe brasileira, } \S 944 \text { do Capítulo } 2^{\mathrm{o}} \text { da } \\
\text { Parte } 3^{\mathrm{a}} \text { titulo } 1^{\mathrm{O}} \text {; } \\
\ldots \text { fundado nas authoridades de Al- } \\
\text { meida e Sousa, Mello Freire, Correia } \\
\text { Telles, Casemiro Ramalho... (F41R } \\
\text { L5) }\end{array}$ \\
\hline D12A6 & $\begin{array}{l}\text { apelantes } \\
\text { apelado } \\
\text { juiz de direito } \\
\text { procurador da Corôa } \\
\text { autoridade (lei) }\end{array}$ & $\begin{array}{l}\text { libertandos Raphael e Jesuino } \\
\text { réu João José - ...fallando as partes....e } \\
\text { o reo de folhas... (F55R L9) } \\
\text { proferiu o Juiz de direito.sua sen- } \\
\text { tença...julgando... (F55R L12) } \\
\text {...que opina pela reforma da sentença... } \\
\text { (F55R L21) } \\
\text { disposição do } \S 6^{0} \text { do artigo } 5^{\mathrm{o}} \text { da Lei de } \\
28 \text { de Setembro de } 1871 ;\end{array}$ \\
\hline
\end{tabular}




\begin{tabular}{|c|c|c|}
\hline D13S7 & $\begin{array}{l}\text { autor } \\
\text { réu } \\
\text { autoridade (doutrina) } \\
\text { autoridade (jurisprudência) } \\
\text { autoridade (lei) } \\
\text { testemunha } \\
\text { todo o processo }\end{array}$ & $\begin{array}{l}\text { Pardo Antonio Leite dos Santos } \\
\text { Padre Antonio Luis dos Reis França } \\
\text {...Mello Freire (ilegivel) Direito Civil } \\
\text { Livro 4... (F68V L23) } \\
\text { Revista Jurídica } \\
\text { Acórdão Relação da Corte; } \\
\text { aresto do Tribunal de Justiça } \\
\text { Lei de } 6 \text { de Junho; } \\
\text { Ordenações Livro } 4 \text { titulo 11; } \\
\text { Lei } 1 \text { de Abril de } 1680 ; \\
\text { depoimento das testemunhas do réu } \\
\text {...Por todo o deduzido, e o mais que dos } \\
\text { autos consta... (F70R L31) }\end{array}$ \\
\hline
\end{tabular}

\begin{tabular}{|c|c|c|}
\hline D14A7 & $\begin{array}{l}\text { apelante } \\
\text { apelado } \\
\text { autoridade (jurisprudência) } \\
\text { procurador do réu } \\
\text { juiz de direito } \\
\text { procurador } \\
\text { sentença }\end{array}$ & $\begin{array}{l}\text { Padre Antonio Luis - ...comparecem } \\
\text { o Réu Appellante por seu Procurador } \\
\text { apresentar defesa... (F97R L8) } \\
\text { autor Antonio Leite dos Santos (es- } \\
\text { cravo) } \\
\text { Acórdão de } 14 \text { de Novembro de } 1876 \\
\ldots \text {..o procurador do Réu appellante fez o } \\
\text { mesmo, e concluio... (F98R L30) } \\
\text {...proferio elle a sentença... (F98V L3) } \\
\text {...Ilustríssimo Dezembargador Procura- } \\
\text { dor da Corôa pedio que se ... (F98V } \\
\text { L20) } \\
\text {...confirmam a sentença appellada por- } \\
\text { que seos fundamentos saõ procedentes... } \\
\text { (F99R L6) }\end{array}$ \\
\hline
\end{tabular}


Agora, passaremos à busca das estratégias linguísticas utilizadas para trazer estes outros, a começar pelos discurso citados. Para tanto, faremos também quadros analíticos, separando os discursos citados em discurso indireto, direto e em modalização segunda, conforme a ordem de aparição na respectiva parte do documento ${ }^{1}$, seguidos dos enunciados e de seus introdutores, a caracterizarem o tipo de discurso. Estes enunciados virão seguidos da marcação do fólio e linha que aparecem.

Quadros-resumo: Identificação dos discursos citados e dos seus introdutores.

\begin{tabular}{l|l}
\hline D1S1 & \\
\hline RELATÓRIO & Discursos Indiretos \\
& - voz autor- Allega o escravo Benedicto... que (F68V L1) - \\
& aparece mais sete vezes (L4, 9, 12, 17, 19; F69R L1, 7,); \\
& voz do réu - O réo contrariando allega; que... (F69R L17)- \\
& aparece mais três vezes (L21, 24; F69V L5) \\
& Discurso em modalização segunda \\
& - voz da lei - (conforme) $)^{7}$ restos do Tribunal da Relação (F68V \\
& L15); \\
& pela doutrina da ... (F69R L9) \\
\hline FUNDAMENTAÇÃO & Discursos Indiretos \\
& sem ocorrência \\
& Discurso em modalização segunda \\
& como primão os documentos de folhas... (F70R L4) \\
\hline DECISÃO & Discurso Indireto \\
& e na forma do artigo... (F70R L8) \\
\hline
\end{tabular}

${ }^{1}$ Se sentença, aparecerá o Relatório, Fundamentação e Decisão, como parte integrante do documento, e, no caso do Acórdão, somente Relatório e Decisão.

${ }^{6}$ Discursos citados detectados e seus introdutores em negrito.

${ }^{7} \mathrm{O}$ conectivo introdutor do discurso modalizador não aparece expresso - mas entendemos como "conforme", "segundo" referida doutrina, porque o juiz está baseando sua fundamentação, seu enunciado, no que já foi dito por um autor, em seu livro, portanto, ele molda o que foi dito e o insere em seu discurso.

${ }^{8}$ Aparece mais duas vezes, trazendo mais duas alegações, mas com o verbo "responder" implícito.

${ }^{9}$ Aqui também o conectivo introdutor do discurso modalizador não aparece expresso - mas entendemos como "conforme", "segundo" referida doutrina; o mesmo entendimento da nota 7.

${ }^{10}$ Aqui também o conectivo introdutor do discurso em modalização segunda não aparece expresso. Entretanto, podemos observar que o enunciado do juiz aparece pautado pelas referidas citações das Leis, ou seja, o juiz traz o conteúdo destas Leis para o seu discurso, e o molda segundo suas intenções de fundamentação.

${ }^{11} \mathrm{O}$ pondera está implícito, sendo expresso apenas o conectivo que, indicando a continuação do discurso indireto do juiz, que está trazendo as alegações da Autora Emiliana.

${ }^{12} \mathrm{O}$ allegando está implícito, aparecendo somente o conectivo "que" para introduzir as outras alegações do Réu. 


\begin{tabular}{|c|c|}
\hline D2A1 & \\
\hline RELATÓRIO & 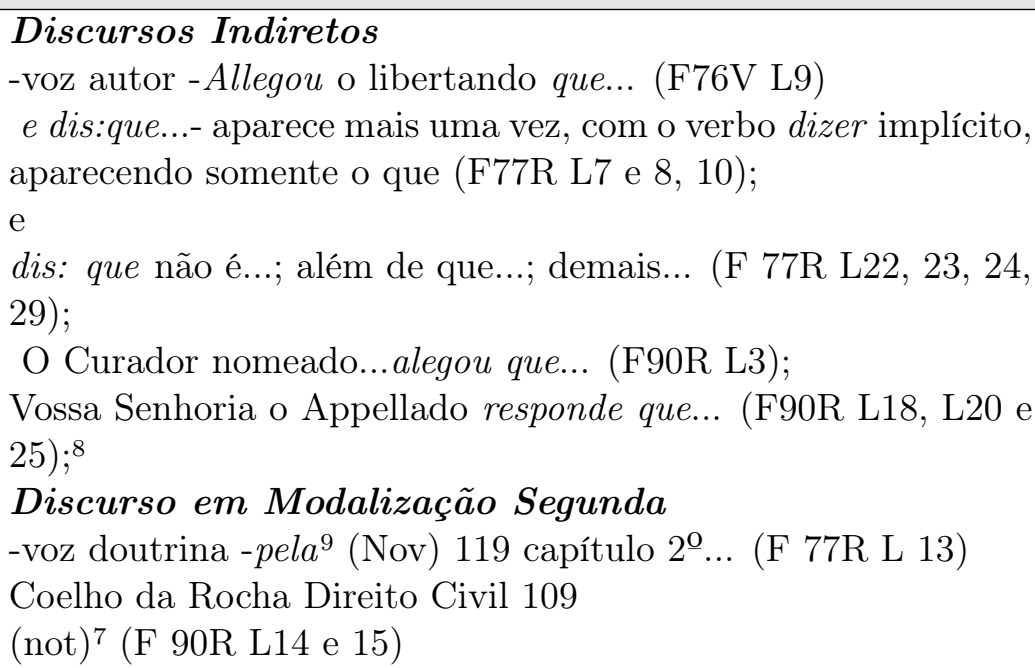 \\
\hline DECISÃO & $\begin{array}{l}\text { Discurso em Modalização Segunda } \\
\text { - voz documental -segundo os documentos de folhas } 3 \text { e } 22 \text { (F } \\
90 \mathrm{~V} \text { L } 21)\end{array}$ \\
\hline D3S2 & \\
\hline RELATÓRIO & $\begin{array}{l}\text { Discursos Indiretos } \\
\text { - voz do Autor - Mostra-se por parte da Autora que (F32R L5, } \\
\text { L12); Mostra-se ainda que (F32R L17); } \\
\text { - voz do Réu - Por parte do Réu appraz-se...que (F32V L1 e } \\
\text { L2) }\end{array}$ \\
\hline FUNDAMENTAÇÃO & $\begin{array}{l}\text { Discursos em Modalização Segunda } \\
\text { - voz doutrina- ... de conformidade com a Lei } 19 \text { de Agosto } \\
\text { de } 1769 \ldots \text { (F32V L } 26 \text { e } 27) ; \ldots \text { como declaraõ os Estatutos da } \\
\text { Universidade de } 28 \text { d'Agosto de ... (F32V L31); } \\
\text { Arestos Lei } 4 \text { Titulo } 11 \S 4^{\mathrm{o}} \ldots \text { (F33R L39); Lei de } 1^{\mathrm{o}} \mathrm{d}^{\prime} \text { Abril } \\
\text { de } 1680 \ldots \text { (F33R L42); Lei } 20 \text { de regimento juridico... (F33R } \\
\text { L47); } 10\end{array}$ \\
\hline DECISÃO & nenhuma ocorrência de discurso citado. \\
\hline
\end{tabular}

\footnotetext{
${ }^{13}$ Aqui também implicita a locução verbal "pretende provar", que entendemos com o sentido de verbo discendi, visto que objetiva a colocação a alegação da autora, sob a voz do juiz narrador.

${ }^{14} \mathrm{O}$ verbo alegar virá implícito nestas outras alegações dos autores, aparecendo somente o conectivo que.

${ }^{15}$ Aqui encontramos também um discurso direto, dentro do discurso em modalização segunda, porque o juiz, além de moldar seu discurso conforme a outra decisão do Tribunal, ele também traz, de forma indireta (decidido que) o discurso da outra decisão.

${ }^{16}$ Voz da ex senhora dos apelantes, trazida pelo juiz, por intermédio da voz das alegações dos apelantes, via discurso indireto.

${ }^{17}$ O verbo alegar está implícito, aparecendo apenas o conectivo "que" para introdução do discurso indireto que traz a voz dos réus.
} 


\begin{tabular}{|c|c|}
\hline $\mathrm{D} 4 \mathrm{~A} 2$ & \\
\hline RELATÓRIO & $\begin{array}{l}\text { Discursos Indiretos } \\
\text { - voz autora-Allega ter nascido em... (F50V L9); E mais pon- } \\
\text { dera que... (F50V L20); (F50V L27; F51R L1, L8, L16)11 } \\
\text { Discurso Direto- } \\
\text {-dentro da citação do documento, o discurso direto: - "Bem } \\
\text { assim lhe dou (á uma sobrinha beneficiada), o serviço da... } \\
\text { (F50V L15 L15); } \\
\text { " E se neste tempo tiver alguns filhos... (F51V L6); "e á mae } \\
\text { dá-se a liberdade" (F 50V L26, F51V L8) } \\
\text { Discurso em Modalização Segunda } \\
\text { - segundo a voz documental - ...constante do documento em } \\
\text { original a folhas 26: (F50V L14); } \\
\text { :. segundo os documentos que apresenta... (F51R L7 e 8); }\end{array}$ \\
\hline DECISÃO & $\begin{array}{l}\text { Discurso em Modalização Segunda- } \\
\text { - voz sentença - .. por seos fundamentos... (F52R L11) } \\
\text { - ...conformes à Direito... (F52R L7); } \\
\text { - todas as vozes dos autos(autor, réu, juiz, documentos, } \\
\text { testemunhas)- } \\
\text {...e ao que consta dos autos... (F52R L13) }\end{array}$ \\
\hline \multicolumn{2}{|l|}{ D5S3 } \\
\hline RELATÓRIO & $\begin{array}{l}\text { Discursos Indiretos } \\
\text { - voz do autor -... pretende provar que... (F41R L3 e L4); Que } \\
\text { favorecendo... (F41R L9) }{ }^{13} \text {; } \\
\text { - voz do réu- Oppoẽ a esta pretençaõ ... allegando que...(F41R } \\
\text { L13 e L14); Acrescenta...que... (F41R L20) }\end{array}$ \\
\hline FUNDAMENTAÇÃO & $\begin{array}{l}\text { Discurso em Modalização Segunda } \\
\text { - voz da jurisprudêcia - considerando os Arestos dos Tribunais } \\
\text { Superiores... (F42R L16); ...como ainda há pouco decidira o } \\
\text { Juiz Marechal da } 2^{\mathrm{a}} \text { Vara... (F42R L23)...sentença esta que } \\
\text { fora confirmada por dous Accordaõs... (F42R L25) }\end{array}$ \\
\hline DECISÃO & $\begin{array}{l}\text { Discurso em modalização Segunda } \\
\text { - voz da legislação - Assim, julgando, e de conformidade com } \\
\text { a Lei de } 28 \text { de Setembro... (F42R L31); }\end{array}$ \\
\hline
\end{tabular}

\footnotetext{
${ }^{18} \mathrm{O}$ verbo alegar está implícito nestas outras duas enunciações, que continuam trazendo a voz do réu por intermédio do discurso indireto, por isso, assim o classificamos.

${ }^{19}$ Aqui também o verbo alegar encontra-se implícito, aparecendo somente o conectivo "que".

${ }^{20} \mathrm{Da}$ mesma forma aqui, o verbo dizer está implícito.
} 


\begin{tabular}{|c|c|}
\hline D6A3 & \\
\hline RELATÓRIO & 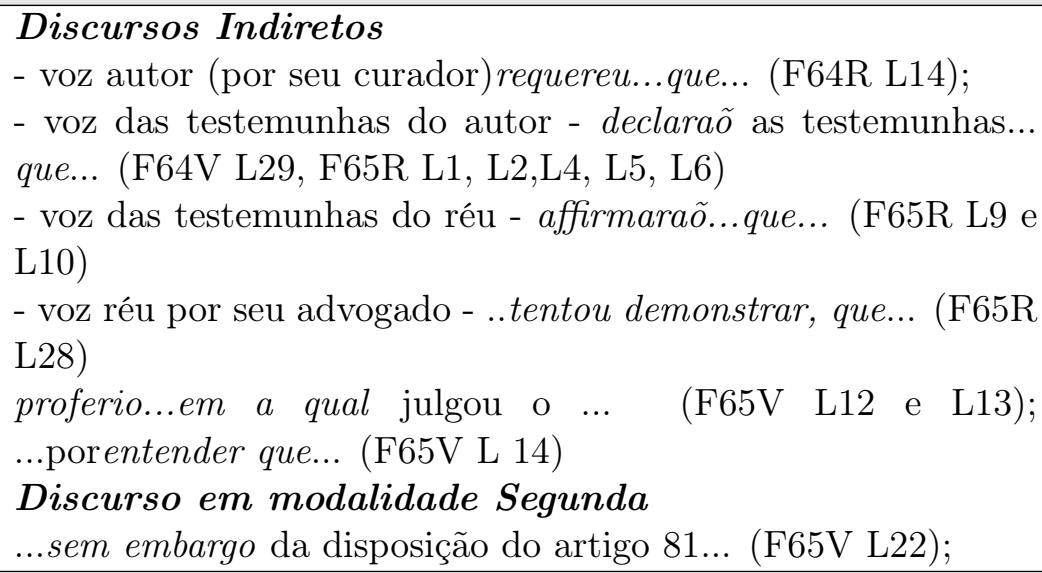 \\
\hline DECISÃO & $\begin{array}{l}\text { Discurso em modalização Segunda } \\
\text { - voz sentença- Confirmaõ a sentença apellada pelos seos fun- } \\
\text { damentos... (F68R L6) } \\
\text {...conforme a direito e às provas dos autos (F68R L8) }\end{array}$ \\
\hline
\end{tabular}

\begin{tabular}{|c|c|}
\hline D7S4 & \\
\hline RELATÓRIO & $\begin{array}{l}\text { Discursos Indiretos } \\
\text { - voz dos autores -.. allegam os autores...que... (F84V L1 e } \\
\text { L3); (L6, L8, L10) } \\
\text { - voz dos réus- ...disendo que... (F85R L1) }\end{array}$ \\
\hline FUNDAMENTAÇÃO & $\begin{array}{l}\text { Discurso Indireto } \\
\text { - voz testemunhas- ...as informantes affirmam ter Dona Theo- } \\
\text { dora dito que... (F85R L19 e L20); } \\
\text { As testemunhas...apenas referem que... (F 85R L32 e L33) }\end{array}$ \\
\hline DECISÃO & $\begin{array}{l}\text { Discurso em modalização Segunda } \\
\text { - voz da jurisprudência - ...como já foi decidido pela Relação } \\
\text { da Corte que... (F } 85 \mathrm{~V} \text { L 15) }\end{array}$ \\
\hline
\end{tabular}

\begin{tabular}{l|l}
\hline D8A4 & \\
\hline RELATÓRIO & Discursos Indiretos \\
& - voz autores apelantes - ...emphallegando...que... (F91R L6 e \\
& L7); \\
& $-\ldots$ dissera por vezes que... (F91R L10 e L11) ${ }^{16} ;$ \\
& voz dos réus - ...allegando que... (F91V L4); (F91V L9 e L11) ${ }^{17}$ \\
\hline DECISÃO & Discurso em modalização Segunda \\
& - voz sentença- .... negaõ provimento a appellaçaõ..., conforme a \\
& direito e às provas dos autos (F92R L13 e L14) \\
\hline
\end{tabular}

\begin{tabular}{l|l}
\hline D9S5 & \\
\hline RELATÓRIO & $\begin{array}{l}\text { Discursos Indiretos } \\
\text { voz do réu - ...protestou Tristão da Cunha, allegando que... }\end{array}$ \\
\hline FUNDAMENTAÇÃO & não há ocorrências de discursos citados; \\
\hline DECISÃO & não há ocorrências de discursos citados. \\
\hline
\end{tabular}




\begin{tabular}{l|l}
\hline D10A5 & $\mid$ \\
\hline RELATÓRIO & $\begin{array}{l}\text { Discursos Indiretos } \\
\text { voz do réu - ...allegando que... (F115V L8); ...allegou que... } \\
\text { (F1116R L17) }\end{array}$ \\
\hline DECISÃO & $\begin{array}{l}\text { Discurso em modalização Segunda } \\
\text { - voz sentença- ...por seos fundamentos.... (F117V L9) } \\
\text { - voz da legislação - ...nos termos do artigo 80 do Regula- } \\
\text { mento... (F117V L14); }\end{array}$ \\
\hline
\end{tabular}

\begin{tabular}{l|l}
\hline D11S6 & \\
\hline RELATÓRIO & não há ocorrências de discurso citado \\
\hline FUNDAMENTAÇÃO & $\begin{array}{l}\text { Discurso } \text { em } \text { modalização } \text { Segunda } \\
\text {...Como ensina... (F40V L10); }\end{array}$ \\
\hline DECISÃO & não há ocorrências de discurso citado. \\
\hline
\end{tabular}

\begin{tabular}{l|l}
\hline D12A6 & \\
\hline RELATÓRIO & Discursos Indiretos \\
& - voz dos autores - ...requereraõ...que... (F54R L5); allegaõ para \\
& isso.... (F 54V L3); \\
\hline DECISÃO & não há ocorrências de discursos citados. \\
\hline
\end{tabular}

\begin{tabular}{|c|c|}
\hline D13S7 & \\
\hline RELATÓRIO & $\begin{array}{l}\text { Discursos Indiretos } \\
\text {-voz do autor - ...pretende provar...que... (F68R L1 e L3);... } \\
\text {-voz do réu - ...allega principalmente... (F68V L9 e L10);...ter } \\
\text { sido... (F68V L13 e L15) }\end{array}$ \\
\hline FUNDAMENTAÇÃO & $\begin{array}{l}\text { Discurso Direto } \\
\text {..."aqueles que impugnam a liberdade incumbe prova..." (F69R } \\
\text { L1); }\end{array}$ \\
\hline DECISÃO & $\begin{array}{l}\text { Discurso em modalização Segunda } \\
\text { - todas as vozes dos autos - por todo o deduzido, e o mais que } \\
\text { dos autos consta... (F70R L31 e L32); }\end{array}$ \\
\hline
\end{tabular}

\begin{tabular}{|c|c|}
\hline D14A7 & \\
\hline RELATÓRIO & $\begin{array}{l}\text { Discursos Indiretos } \\
\text {-voz do autor - ...allegou...que... (F97R L24 e L25); ...que... } \\
\text { (F97R L29; F97V L12);19 } \\
\text {-voz do réu - ...O réu appellante...diz que... (F97V L18); ...E } \\
\text { que... (F97V L23) } \\
\text { - voz procurador do réu apelante - ...e concluio pedindo que... } \\
\text { (F98R L31 e L32); } \\
\text { - voz procurador da Corôa - ...pedio que... (F98V L20 e L21); }\end{array}$ \\
\hline DECISÃO & $\begin{array}{l}\text { Discurso em modalização Segunda } \\
\text { - todas as vozes dos autos - conforme com o que consta dos } \\
\text { autos ...(F95R L9 e L10); }\end{array}$ \\
\hline
\end{tabular}


Até aqui, então, fizemos, primeiramente, o levantamento das outras presenças, das outras vozes emergentes nos documentos. Em seguida, detectamos quais vozes foram trazidas por intermédio dos discursos citados. Cabe-nos agora, neste momento, analisar as outras vozes trazidas por outras estratégias, como também fazer as devidas conexões entre as vozes e os recursos, para sabermos de que maneira elas contribuem para a construção dos sentidos destes discursos.

Por ora, após estes breves levantamentos, já nos restou clara a variedade de vozes sociais $^{2}$ contidas nestas decisões. Em cada parte destes documentos estas presenças são manejadas conforme as coerções do gênero, aliadas às estratégias argumentativas do juiz, que pretenderá fazer valer a sua decisão. A seguir, passaremos, então, às interpretações das estratégias utilizadas pelos magistrados, para que cheguemos, enfim, ao sentido produzido por estes discursos.

\subsubsection{Em busca do sentido: as sentenças}

Passemos à análise da materialidade codicológica das sentenças, primordial para partimos para a análise da constituição do gênero e compreensão das formas de produção de sentido.

Nosso corpus é constituído de sentenças manuscritas, de próprio punho, pelo juízes que as julgaram. Os documentos se apresentam sem qualquer marcação ou timbre representativo do Poder Judiciário, diferentemente dos da atualidade, cujas sentenças são digitalizadas em folhas timbradas com o símbolo do Poder Judiciário. O suporte empregado é o papel (folhas pautadas), tamanho aproximado de $28 \mathrm{X} 20 \mathrm{~cm}$, apenas com a marcação da páginas no anverso e canto superior direito, porém a marcação é feita pelo próprio escrevente, funcionário do Cartório onde tramitava o processo.

\footnotetext{
${ }^{2}$ Como já vimos, estas vozes sociais representam os outros discursos, ou seja, sujeitos como um conjunto de relações socio-históricas; a constante interação dos sujeitos, a práxis da língua, a relação dialógica destes outros discursos que permeiam este discurso narrativo.
} 
Assim, estes julgamentos se apresentam como continuidade dos demais atos do processo, ou seja, na mesma folha em que aparecem registrado pelo punho do escrivão responsável e, naquela data, seria encaminhado ao juiz competente para julgar. Em seguida, após algumas linhas, o juiz-autor do discurso inicia a sentença com dizeres padronizados, que caracterizam o gênero e o início da parte da sentença que conterá o Relatório: "Vistos e Examinados os autos"/"Vistos estes autos". Estas formas cristalizadas nas decisões simbolizam o ato de verificação de todo o processo pelo juiz responsável, que viu e examinou tudo, todos os atos, peças processuais, incidentes, que fizeram parte do processo.

Todas as sentenças apresentam as formas padronizadas, caracterizadoras do gênero. Como explicitado, este gênero possui requisitos indispensáveis de construção, e estas formas cristalizadas irão introduzir cada parte deste documento. Vejamos, a D1S, D3S, D9S, D11S dão início a primeira parte denominada RELATÓRIO com a expressão "Vistos estes autos", procedendo, da mesma forma, os juízes na D7S, D13S, D5S, que utilizam a expressão "Vistos e examinados os autos".

Como já salientado, é cediço que o gênero jurídico encontra-se na lista dos menos propícios às marcas de estilos individuais, justamente pelo uso contínuo e obrigatório de formas cristalizadas, que acabam caracterizando o tipo de documento, dentro daqueles existentes na esfera jurídica. Mas, como veremos, estas formas padrões não neutralizam pistas denunciadoras da construção de um discurso direcionado, intencional, com profundos sinais ideológicos (os favoráveis à liberdade, denunciando a posição de abolicionista, aqueles que negaram a liberdade, revelando uma tendência escravocrata) ${ }^{3}$.

\footnotetext{
${ }^{3}$ Ideologia aqui do ponto de vista Bakhtiniano, que partindo do conceito Marxista de ideologia, o reconstrói acrescentado, ao lado da ideologia oficial, entendida como relativamente dominante, implantando uma concepção única de produção do mundo, a ideologia do cotidiano, que é a que "brota e é constituída nos encontros casuais e fortuitos, no lugar do nascedouro dos sistema de referência, na proximidade social com as condições de produção e reprodução da vida. (...) uma relação dialética se dando entre ambos, na concretude. De um lado, a ideologia oficial, como estrutura ou conteúdo, relativamente estável; de outro, a ideologia do cotidiano, como acontecimento,
} 


\subsubsection{Sentenças D3S e D5S}

Seguindo ainda no RELATÓRIO, que tem por objetivo expor um breve resumo do processo, o magistrado, na D3S, apresenta as partes e então parte para exposição sintética das suas alegações. Para a autora, gasta-se muito mais linhas, três períodos, fazendo uma exposição mais longa, narrando três argumentos utilizados pela mesma para fundamentar seu pedido de liberdade. Nesta narrativa, utiliza-se do verbo "mostrar" mais a conjunção "que" para introduzir o discurso indireto (mostra-se, mostra-se mais, mostra-se ainda).

No RELATÓRIO e na FUNDAMENTAÇÃO, o discurso citado é um recurso recorrente utilizado pelo juiz-autor. No RELATÓRIO, ocasião em que a juíza exporá os argumentos trazidos por cada uma das partes do processo, ela o fará por intermédio do discurso indireto. Ela trará a voz destes outros personagens principalmente com o verbo introdutor "mostrase", objetivando, com isto, isentar-se de qualquer posicionamento, visto que ainda não é o momento para tal envolvimento, nesta parte do gênero. Para dar voz ao réu, utiliza-se somente uma vez do discurso indireto, com o verbo introdutor "appraz-e" (F32V L1). Isto confirma a tese inicial que o juiz de D3S, já desde o RELATÓRIO, deixou prenúncios de sua decisão final procedente para o Autor, sendo muito breve e objetivo no momento em que deu a voz ao Réu. Na FUNDAMENTAÇÃO, que inicia, como já observado, com a expressão "Considerando que", que se repete durante toda a fundamentação, o juiz também utiliza-se de sua voz para dar voz à um instituto do Direito Romano, por exemplo, no trecho "não se verifica o statuliber- do Direito Romano..." "...porque o statuliber- é aquelle em que a liberdade era determinada para certo tempo ou ficava dependente de condição..." (F32V L9). Continua fazendo outras citações de leis, de Estatutos de Universidades, de

relativamente instável; e ambas formando o contexto ideológico completo e único, em relação recíproca, sem perder de vista o processo global de produção e reprodução social" (MIOTELLO, 2010: 168 e 169 in BRAIT, 2008). 
outros Códigos, de livros, como no trecho "... e cuja doutrina encontramos adotada pela obra - A escravidão no Brazil - do Doutor Perdigão..." (F33R L12).

Neste momento, se faz necessário alguns esclarecimentos sobre algumas noções usadas em nossas análises. Como ensina Koch (2002: 72) "na estruturação do discurso, a relação entre enunciados é freqüentemente projetada a partir de certas relações de modalidade, donde se depreende a sua importância pragmática." Assim, estes elementos modalizadores, através dos quais o sujeito expressará sua adesão ao texto, nos mostrará a atitude deste autor do discurso na defesa do sentido que pretende. Koch (2002: 86) ainda destaca que:

O recurso às modalidades permite, pois, ao locutor marcar a distância relativa em que se coloca com relação ao enunciado que produz, seu maior ou menor grau de engajamento com relação ao que é dito, determinando o grau de tensão que se estabelece entre os interlocutores; possibilita-lhe, também, deixar claros os tipos de atos que deseja realizar e fornecer ao interlocutor "pistas" quanto às suas intenções; permite, ainda, introduzir modalizações produzidas por outras "vozes" incorporadas ao seu discurso, isto é, oriundas de enunciadores diferentes; torna possível, enfim, a construção de um "retrato" do evento histórico que é a produção do enunciado.

Essas pistas ou marcas linguísticas, deixadas pelo enunciador, virão representadas por advérbios, adjetivos, verbos, conjunções. No caso dos discursos citados, os verbos dicendi serão os modalizadores, ou seja, aqueles que condicionarão e direcionarão a interpretação que os locutores farão do enunciado. São verbos de elocução, de declaração, no intuito de incorporar a voz alheia ao discurso narrativo. (TOMÁS, 2011) Ainda, como modalizadores, nosso corpus traz também as conjunções conformativas (introdutórias dos discursos em modalização segunda) e os enunciados performativos, que, de acordo com Cervoni (1989), 
são aqueles enunciados que executam uma ação, no momento da enunciação, por exemplo,

"Julgo Improcedente", "Dá-se provimento ao presente recurso de apelação".

Continuando nossa análise da D3S, vemos o verbo mostrar, como um verbo de declaração, que introduzirá a fala de outrem, de forma indireta. Ataíde (1998), baseada em Othon Marques Garcia (1986), quando estuda os verbos dicendi no discurso jornalístico, estabelece uma relação dos verbos considerados dicendi, estando, dentre eles, o verbo mostrar. Ela coloca também que estes verbos se apresentam em duas classes: declarandi ou dicendi, e sentiendi ou de sentir:

Esses verbos são vicários ou variações dos verbos de elocução, pois fazem as vezes destes. Ou seja: do ponto de vista lógico-sintático presumem a existência de um legítimo dicendi oculto. Mas, como variação dos dicendi, expressam a carga de afetividade presente na língua falada. (ATAÍDE, 1998: 1)

Quando vamos ao significado do verbo mostrar, vemos que ele tem um sentido muito mais amplo, quando comparado com o verbo aprazer, utilizado para introduzir os argumentos do réu. De acordo com o dicionário Houaiss (HOUAISS \& VILLAR ${ }^{4}$ ), mostrar tem como sinônimos tornar patente, indubitável, evidente; evidenciar, provar, demonstrar, enquanto que aprazer, neste contexto, significa contentar-se. Neste momento já percebemos evidências de seu julgamento final. O autor prova, evidencia, demonstra, enquanto que " Por parte do Reu appraz-se a matéria de allegação defolhas 26..." (F32V L1), ou seja, sua alegação se perfaz, satisfaz-se somente e tão apenas com a alegação de uma folha do processo (folhas 26), descrevendo, a seguir, o único argumento sob a qual ela se funda. Podemos dizer que o verbo aprazer, está na categoria dos sentiendi, porque expressa um

\footnotetext{
${ }^{4}$ Disponível em http://houaiss.uol.com.br/busca.jhtm. Acesso em 19.05.2012
} 
sentimento do réu, como se seus argumentos fossem satisfeitos apenas com a alegação de folhas, que resumidamente é trazida pelos juiz.

Isto porque, como já explicitado, para exposição dos argumentos do réu, utiliza apenas um período, e relata apenas um argumento do mesmo. Ao trazer os argumentos expostos pela Autora, por intermédio de seu curador, em peça dos autos (inicial, manifestações), temos aí o juiz-autor criador do seu discurso, trazendo voz à autora, por intermédio de sua voz, e ainda mais, da sua maneira e sob o seu crivo. Isto porque, como dissemos, há várias oportunidades de manifestações das partes, durante o processo, e o Juiz, no momento da confecção da sentença, trará para o seu discurso, sob o seu estilo e viés, os fatos que entender mais convenientes e a quantidade que entender suficiente para formação de seu discurso. Como levantamos, o autor-criador de D3S, que proferirá uma sentença procedente, ou seja, favorável à autora, trouxe para sustentar sua decisão três períodos com os argumentos trazidos aos autos pela autora (F32R L5, L12, L17) e transcritos para a sentença sob a sua voz. Enquanto que quando parte para narrar os fatos trazidos pelo réu, gasta apenas um período (F32V L1), e de forma muito objetiva dá voz apenas a um argumento cotejado pelo mesmo.

Dentro da exposição dos argumentos da autora, o juiz utiliza-se também do discurso direto, ao trazer as palavras do doador, presentes no testamento do Padre Agostinho, na tentativa de reproduzir fielmente a fala deste doador, que ao conceder a liberdade à mãe da autora, estaria, consequentemente, a libertando. É uma fala que sustenta toda a sua fundamentação, que baliza sua decisão. Assim, muito mais credibilidade teria se trazida por meio do discurso direto, ou seja, direto da fonte, a fim de não gerar qualquer dúvida interpretativa, ou seja, o autor joga sobre o herói a responsabilidade daquilo que é dito.(Bakhtin, 2010).

Já na parte da Fundamentação, o juiz da D3S irá narrar todos os seus argumentos 
utilizando-se do verbo considerar, no gerúndio, "considerando". Aqui tentará demonstrar uma total imparcialidade, porque o verbo está sendo utilizado no gerúndio, ou seja, de forma impessoal, como se isentasse totalmente do dizer, como também, ao buscarmos o sentido do verbo considerar, encontraremos como sinônimos olhar(-se), fitar(-se) com atenção e minúcia, no primeiro sentido e em uma derivação por extensão do sentido, significará refletir sobre uma coisa, um fato, uma possibilidade, sobre alguém ou sobre si mesmo; pensar. (HOUAISS \& VILLAR ${ }^{5}$ ). Ou seja, o verbo utilizado continua demonstrando que são argumentos que são acarreados para se construir a decisão, para que o interlocutor pare, pense, reflita sobre as informações trazidas e, a partir daí, se convença da decisão que ao final será anunciada.

Para trazer força aos seus argumentos, que até então intencionam uma ação do locutor, ou seja, fazê-lo refletir e ao final convencê-lo, o juiz também traz leis, doutrinas, outros julgamentos (F 32V, L20, L25, L31; F33R L 30, L39, L42, L47), como vozes de autoridade, incontestáveis. Ou seja, ele mescla seu discurso narrativo de palavras persuasivas, como por exemplo, o verbo introdutor considerar, com palavras de autoridade, representadas pelas leis, que por si só se valem, são incontestáveis. E ao mesmo tempo, este juizcriador abre espaço para outras vozes, mostrando que seu posicionamento é validado pela lei, por estudiosos (doutrinadores), por outros julgadores (outras decisões citadas). Para finalizar seus argumentos, o juiz traz a voz do outro com latinismos, ou seja, palavras em latim "Partus sequitu suntrem". Conforme bem explana Freitas (2008), nem todos os interlocutores entendem expressões jurídicas. Nestas decisões, os interlocutores eram os escravos, representados por seus curadores. Certamente, ao trazer estas expressões clássicas, o juiz se distancia do interlocutor comum, mas, ao mesmo tempo, impressiona 
àqueles que não conhecem esses termos e persuadi os que sabem, mostrando que ele domina a matéria e o vocabulário da área.

O juiz então, estando certo de que seus fundamentos convenceram seus interlocutores, anuncia, com um enunciado performativo, o seu "Julgo por bons estes fundamentos a Autora livre, e condendo ao Réu nas custas." (F33R L54). Declara finalmente sua decisão de procedência, favorável à autora, decisão esta anunciada desde o início de seu relatório.

Ao observarmos o juiz da D5S, ele apresenta as partes seguidas de seus argumentos. Para o autor, reserva uma parte menor de exposição, utilizando-se da locução verbal "pretende provar" ao contrário da D3S, que dispensa parte menor ao réu. Com "opõe-se a esta pretensão" (F41R L13), introduz o longo período na qual expõe as fundamentações do réu. Utiliza também "acrescenta além dessa razão" (F41R L20) para narrar outro fundamento do réu. Faz referência a Lei de 7 de Novembro de 1831, que declara livres todos os escravos vindos de fora do Império, ainda na parte da exposição dos argumentos do réu. De forma oposta ao autor-criador da D3S, como sua decisão final será pela improcedência, ou seja, favorável ao réu, ele dará voz de forma mais extensa ao réu, trazendo muito mais argumentos por ele (Réu) levantados do que para o autor.

Analisando mais detidamente as estratégias linguísticas utilizadas para trazer as outras presenças, nesta parte do RELATÓRIO, verificamos a incidência do discurso indireto, tanto para trazer a voz do autor, quanto para a do réu. Como dissemos, como a decisão final será favorável ao réu, o juiz trará muito mais vezes a sua voz, e assim procede com os verbos alegar, acrescentar, enquanto que para o autor utiliza somente um introdutor, a locução verbal pretende provar, por duas vezes, sendo que na segunda vez, ela aparece implícita (F41R L9). Ao buscarmos no dicionário os significados do verbo pretender, temos ${ }^{6}$ : tentar obter, através de pedido ou exigência; solicitar, pleitear, requerer e num segundo sentido

${ }^{6}$ Disponível em http://houaiss.uol.com.br/busca.jhtm. Acesso em 19.05.2012 
como ter vontade de (obter algo); aspirar a, desejar, querer, demonstrar a verdade, a realidade, a autenticidade de uma coisa com razões, fatos etc (HOUAISS \& VILLAR). Ou seja, o autor tem a intenção de provar, mas não necessariamente tenha conseguido. E a mesma locução é utilizada para as duas introduções indiretas da voz do Autor.

Já para a voz do réu, que aparecerá três vezes, ele usará verbos introdutores diferenciados, o verbo alegar e o verbo acrescentar (duas vezes, na segunda, de forma implícita F 41V L1). Já estes verbos carregam um sentido mais impactante, com mais força argumentativa. O verbo alegar ${ }^{7}$ como referir ou citar para justificar ou fundamentar qualquer pretensão (HOUAISS \& VILLAR). Já o verbo acrescentar, encontramos como tornar(-se) maior em tamanho, número, força, extensão etc.; crescer (em); aumentar(-se); 2. juntar (uma coisa) a (outra); adicionar(-se), anexar(-se). Podemos inferir que os dois verbos denotam a força dos argumentos do réu. O juiz os traz de uma maneira a atribuir-lhes maior credibilidade, já apontando um julgamento prévio sobre estes argumentos, porque, diferentemente do autor, que somente pretende provar, o réu já alegou, afirmou, acrescentou argumentos, de forma muito mais incisiva.

Para enfatizar ainda mais o peso das argumentações do réu, o juiz faz a citação da lei de 7 de Novembro de 1831, sobre a qual girará toda a discussão e prova dos autos. Mas, da mesma forma que abre neste momento um diálogo com a referida lei, valida, com uma voz de autoridade (da lei), a voz do réu. Ou seja, traz a voz do réu, que por sua vez, em suas alegações, trouxe a voz da lei. Um discurso citado, dentro de outro discurso citado. Poderíamos aqui ousar classificar este discurso, tal como fez Melo (2006: 137):

O Discurso Multivocal (DM) em nosso contexto de pesquisa foi considerado aquele que imbricou três discursos: o discurso do eu - do secretário, que cita o discurso do outro - interlocutor, participante do processo interacional, que 
por sua vez cita o discurso de um terceiro. Trata-se de um discurso citado dentro de um discurso citado. As incidências em nosso material de pesquisa se restringem à invocação de vozes de autoridade ditas no discurso citado e introduzidas e incorporadas no discurso do secretário.

Como vimos então, o autor-criador de D3S construirá suas argumentações utilizandose, de forma padrão, da expressão "considerando que" (F32V L7, L17, L22, L33), (F33R L14, L27) no início de todos os períodos que comporão esta parte da sentença. Já o juiz da D5S se utiliza também de um jargão padrão para indicar o início desta parte da sentença: "O que tudo visto e devidamente examinado considerando" (F42V L16). Nos dois casos, o verbo tenta transmitir a ideia de impessoalidade, mesmo se tratando de uma parte do documento que se dedica à exposição do convencimento do juiz, quando então seria esperado a utilização de formas verbais em $1^{\mathrm{a}}$ pessoa. Podemos dizer que é mais um indício da presença de outras vozes neste discurso, como se a sua fundamentação se apoiasse em todas as outras manifestações constantes nos autos (do autor, réu, testemunhas, documentos), estando o juiz, como autor-criador daquela decisão, a manejar as diversas aparições.

Analisando mais detalhadamente os argumentos do juiz na D5S, em sua fundamentação, vimos a presença de muitas outras vozes, a compor o seu discurso. Ele faz referência, em seu discurso narrativo e de forma citada, das falas de várias testemunhas, por exemplo, a testemunha folhas 34, que ignora..." (F41V L21), "como a testemunha de folhas 14 que sabe..." (F41V L26), "como a testemunha folhas 17 Coronel ...que fora" (F41V L28), "como a testemunha de folhas18 que se refere ao..." (F41V L30), "Conciliando por outro lado o depoimento da testemunha defolhas21, que já o conheceu...” (F42R L 11).

Desta forma, por intermédio de seu discurso, ele trará as falas das testemunhas que melhor lhe servem ao seu intento persuasivo. Entretanto, para garantir a adesão ao seu discurso, ele, da mesma forma que o juiz na D3S e em todos os outros julgamentos, dará 
também voz aos Tribunais Superiores, na passagem "Considerando os Arestos dos Tribunais Superiores em questões idênticas, em as quais se tem exigido provas explícitas, claras, e evidentes - de serem vitimas de comerco illicito de escravos..." (F42R L16), ou a voz de outro juiz, de outra Vara, no trecho "como ainda há pouco decidira o Juiz Marechal da $2^{\text {a }}$ Vara da Corte entre partes Maria Africana..." (F42R L23), de forma a validar seu discurso com vozes inquestionáveis, vozes autoritárias, que apóiam suas fundamentações.

Vimos então que, nesta parte da exposição das fundamentações ou razões que justificam a decisão que será anunciada na parte final do documento, os autores juízes se utilizam, de forma muito frequente, dos recursos linguísticos que marcam presença de outras vozes, de outros discursos a compor e validar o posicionamento assumido.

No DISPOSITIVO ou DECISÃO, encontramos novamente, para anunciar a decisão, o chamamento de outras vozes pelo juiz-autor, como que para validar finalmente sua declaração. Em D5S, constataremos a utilização de mais uma expressão padronizada nesta parte do gênero, "Por toda estas razoẽs, e outras que dos autos constaõ..." (F42R L27), expressão esta que anuncia a parte final da sentença como também retoma todas as vozes enunciadas durante todo o discurso e todo o processo, para então dizer a decisão de improcedência da ação intentada, ou seja, para não considerar o Autor escravo livre, decisão esta, anunciada desde os primeiros momentos enunciativos, tal como em D3S. E conclui utilizando-se do discurso em modalidade segunda, "Assim julgando, e de conformidade com a Lei de ..." (F42R L31), trazendo a voz da lei a validar, inquestionavelmente, seu veredicto final.

\subsubsection{Sentenças D1S, D7S, D9S, D11S e D13S}

Em continuidade às interpretações, nos deteremos, em conjunto, aos cinco documentos restantes, que representam as decisões em primeiro grau (sentenças). Em outra oportunidade, passaremos a examinar os acórdãos. 
Iniciaremos pelo documento número um, o mais intrigante, ao nosso ver, como demonstraremos. Isto porque, o juiz-autor da D1S trará ao seu discurso diversas vozes. E estas vozes virão por intermédio de diferentes estratégias, dentre elas o discurso indireto, para trazer a voz do autor e réu, tendo como introdutor destes discursos o verbo alegar, na primeira aparição de forma expressa, e nas outras vezes, quando para introduzir outros argumentos, o verbo alegar estará implícito. Como já analisamos, o verbo alegar, no dicionário apresenta o sentido de referir ou citar para justificar ou fundamentar qualquer pretensão (HOUAISS \& VILLAR ${ }^{8}$ ), e, neste caso, foi o escolhido para introduzir e reformular o discurso das partes. E reformular de forma impessoal, religando-se aos discursos raízes, às pessoas dos discursos citados, convalidando sua posição nesta parte da decisão, que é simplesmente relatar o ocorrido.

Quando traz a voz do autor, em determinado momento traz a voz dos outros julgados, voz esta trazida pelo próprio autor, em suas alegações. Podemos considerar aqui como um discurso citado, dentro de um discurso citado. O juiz deu voz a uma outra decisão, que tinha sido trazida pelo autor em suas peças alegatórias (F68V L15; F69R L 9).

Se parássemos aqui a nossa análise, poderíamos antecipar, seguindo a linha de raciocínio até então elaborada para os dois primeiros julgamentos, que este juiz proferirá uma sentença favorável ao autor, visto que trouxe muito mais argumentos de sua parte, como também vozes de autoridade a validarem o seu discurso. Mas, surpreendentemente, esta não será a decisão.

Para dar voz ao réu, o juiz utilizou-se do mesmo verbo, alegar, passando a impressão de total imparcialidade e isonomia. Entretanto, da voz ao réu menos vezes que ao autor, e também não traz a voz da autoridade para compor estas alegações, que, se fôssemos analisar a peça da defesa do réu, este deve ter se utilizado de leis e outros julgamentos

${ }^{8}$ Disponível em http://houaiss.uol.com.br/busca.jhtm. Acesso em 19.05.2012 
para pautar suas alegações. Mas, elas não foram escolhidas pelo juiz para compor esta parte da decisão.

Em seguida, na parte da FUNDAMENTAÇÃO, da mesma forma que os outros documentos já aqui analisados, este utiliza-se da expressão "Considerando que". Mas diferentemente das outras decisoes, esta fará a citação de diversas folhas dos autos, os retomando a fim de comprovar suas fundamentações (F69V L11, L13, L14, L17; F70R L1, L4). Também como as outras decisões, inicia a parte da DECISÃO com uma expressão padrão: "Considerando finalmente o mais que consta dos autos"..., trazendo à tona tudo o mais que nos autos consta e que não foi levantando por ele neste momento, ou seja, traz todas as outras vozes (testemunhas, documentos, leis, julgamentos) para compor com ele a posição final. De forma surpreendente, então, ele julga o autor carecedor da ação. Esta decisão não se trata de uma decisão de mérito, ou seja, ele julgou que autor não poderia ter ingressado com este tipo de ação, que ele não preenchia os requisitos legais para tal. Assim sinalizou que ele simplesmente se esquivou de decidir o mérito da questão, que era se o autor deveria ou não ser considerado livre. Ele deixou passar a questão da liberdade, e se apoiou em uma questão instrumental, documental, ao considerar a certidão de batismo do autor nula e inapropriada para garantir sua liberdade. A impressão tida aqui é que, na verdade, este juiz, por algum motivo, não poderia dar uma decisão de procedência, ou seja, outras razões o motivaram. Da mesma forma que os outros juízes, de todas as outras sentenças, ele finaliza sua decisão com palavras de autoridade, com a voz da lei a embasar e fortalecer seu veredicto.

De forma muito similar procede o juiz em D7S. Por intermédio dos discursos indiretos, introduzirá as vozes dos autores e réus. Dos autores com o verbo dicendi introdutor alegar, que aparecerá no primeiro argumento, e virá implícito em mais outros quatro. Resumidamente, e sem qualquer menção de lei ou outra voz de autoridade, o juiz expõe as alegações 
dos autores. De forma ainda mais sintética, introduzida pelo verbo dicendi mais legítimo, dizer, ele traz um único argumento do réu. Se formos analisar a força destes verbos, vemos que o dizer, no dicionário, logo no primeiro sentido, aparece como expor através de palavras (alguma coisa) a (alguém); exprimir, enunciar (HOUAISS \& VILLAR ${ }^{9}$ ). Comparando-o com o sentido de alegar, que apresenta-se como referir ou citar para justificar ou fundamentar qualquer pretensão, já percebemos que o dizer exprime uma conviç̧ão maior, um valor mais positivo, de verdade, enquanto que alegar como justificar algo, que precisa ser porque não tem muita credibilidade $^{10}$. Inicia a fundamentação com a expressão padrão "Depois de tudo visto e bem examinado...", seguindo a exposição de seus argumentos com o verbo mostrar, "mostra-se", que tem como sinônimos tornar patente, indubitável, evidente; evidenciar, provar, demonstrar, já anunciando, em seguida, sua decisão, ao dizer que os autores "não provaraõ sua intenção". Introduz esta parte da decisão com um verbo diferente dos demais juízes, utiliza-se de um verbo com mais força, mas, ao mesmo tempo, continua utilizando-o em forma indeterminada, como se estivesse eximindo do que foi mostrado, ou seja, não foi ele que mostrou e sim as partes e as provas dos autos. Segue sua fundamentação trazendo as vozes das testemunhas, principalmente, mas dentro do discurso narrativo, traduzindo suas falas, citando seus discursos totalmente transformados por seu crivo, por seu entendimento e interpretação. Por exemplo, "Nenhuma testemunha affirma ter...", "As informantes (ilegível) Dona Theodora dito que..." As testemunhas Anna Antonia, Luis Antonio Dias de Azevedo..."nada ouviraõ...", As testemunhas Antonio..."apenas referem que..." (F 85R L10, L20, L26, L32). A sua decisão, já anunciada no início da fundamentação, é agora sacramentada com o "Julgo improcedente apresente acçaõ..." (F85V L 21), de

\footnotetext{
${ }^{9}$ Disponível em http://houaiss.uol.com.br/busca.jhtm. Acesso em 19.05.2012

${ }^{10}$ Aqui cabe uma observação: em meus anos de faculdade, na graduação de direito, lembro-me de meus professores, inclusive os de direito civil e processo, orientar-nos para que usássemos, quando em uma peça inicial ou contestação, para falar dos argumentos da parte contrária, o verbo alegar, e quando fôssemos falar de nossos argumentos (da parte que defendíamos), usássemos o verbo dizer.
} 
forma a tomar para si, agora neste momento, a responsabilidade da ação de julgar, com um enunciado performativo. As vozes de autoridade que geralmente aparecem neste momento, vêm antes do veredicto, quando do início desta parte, com um discurso em modalização segunda: " Como já foi decidido pela Relação da Corte...," e dentro deste discurso ele traz diretamente as palavras desta decisão da corte, com um discurso direto que vem sinalizado com uma pausa, dois pontos e o início do enunciado da Corte (F 85V L15). Aqui, também como em D1S, o juiz julga os autores carecedores da ação, ou seja, não julga a questão da liberdade em si, e somente a falta de documento que pudesse embasar o pedido de liberdade.

As decisões D9S e D11S, no que tange à estrutura padrão do gênero, se apresentam diferenciadas, principalmente na parte do RELATÓRIO. Em todas as outras decisões até aqui analisadas, o juiz discorre, de forma contínua, primeiro os fundamentos do autor e depois os fundamentos do Réu. Na D9S o juiz toma como base a ordem de aparição dos atos no processo, ou seja, ele segue apresentando os fatos conforme a ordem das folhas do processo. Assim começa pelo pedido inicial do Autor, constante em folhas 4, resumindo com o pedido de liberdade e depósito. Não fala sobre as justificativas do pedido do autor. Prossegue com as alegações do Réu, introduzindo-as, com um discurso indireto e o verbo alegar. Nesta narração dos argumentos trazidos pelo réu, ele faz várias citações das páginas que constam os referidos atos ocorridos no processo, bem como traz a voz da lei, que foi trazida anteriormente pelo reu: " ...muito depois da Lei de 7 de Novembro de 1831..." (F88V L20); (F89R L10). Apresenta em seguida nova argumentação do autor, mas a traz explicitamente pela voz de Gonçalves, o curador do escravo-autor, tanto que expressa: “ ...pedio a rogo de Miguel a nomeação de outro..." (F89R L22). Prossegue, na ordem em que aparece nos autos, citando as folhas 54, parte em que constam os depoimentos das testemunhas, mas apenas citando estas fase do processo, sem dar voz a estas testemunhas. 
Na parte da DECISÃO, a expressão padrão: " O que tudo visto bem examinado...", " e considerando que..." (F89V L18, L21), cabendo aqui as mesmas análises já feitas. Traz para validar a decisão, neste momento, vozes de autoridade - Doutrinas -, e finaliza seu discurso narrativo com o "Julgo nullo o presente processo pela incompetência do meio..." (F90R L28). Mais uma vez não há o julgamento do mérito, o juiz não decide sobre a liberdade, e sim sobre o meio pelo qual ela estava sendo pedida, considerando-o inadequado. Aqui, o autor fundava seu pedido na Lei de Proibição do Tráfico, Lei de 7 de Novembro de 1831 ao alegar que tivera sido importado depois da lei e por isto sua condição de escravo era ilegal, devendo ser considerado livre. O juiz considerou que, como ele não conseguiu provar que estava na condição de livre, ou seja, as testemunhas não demonstraram que ele estava há muito tempo na condição de livre (fugiu e ingressou com ação de manutenção da liberdade), a ação era impossível juridicamente, já que o objeto dela era manutenção de posse da liberdade, o que o escravo não tinha ainda.

Mais um julgamento no qual o juiz não discutiu o mérito em si, ou seja, não tratou do direito à liberdade, somente se atendo à questões instrumentais, considerando o processo nulo. Cabe indagar: o escravo tinha sido mesmo importado depois da lei de proibição ou não? Por que não discutir o mérito? A rigidez de uma lei processual deve ser mais importante do que uma questão de direito fundamental - a liberdade? Ou então: como poderia o escravo ingressar com uma ação em situação de escravo ainda? Vemos em todos os outros casos que os escravos também encontravam-se fugidos, ou seja, ainda não tinham a posse da liberdade.

A decisão seguinte, D11S, apresenta o mesmo tipo de ação de manutenção de liberdade, com a mesma causa de pedir, ou seja, a manutenção da posse da liberdade pelo escravo, que não se encontrava momentaneamente escravizado. Semelhante à decisão anterior, esta também não apreciará o mérito, se atendo a questões processuais, instrumentais. O que 
nos chama a atenção na comparação destes dois casos são os julgamentos em segunda instância que terão: foram diferentes, ou seja, sentença D9S é confirmada pelo Tribunal, permanecendo o escravo na situação de escravo (Acórdão D10A), mas a decisão D11S é reformada pelos juízes da Relação, que deixam de se ater às questões incidentais, enfrentam definitivamente o mérito, a liberdade. Perguntamo-nos: por que três decisões (as duas sentenças - D9S e D11S e um dos acórdãos D10A) não discutiram o mérito em si, ou seja, não trataram do direito à liberdade, somente se atendo a questões instrumentais, considerando os processos nulos? Por que não verificaram, já que tinham os depoimentos testemunhais e documentos nos autos, se os escravos tinham sido mesmo importados depois da lei de proibição ou não? A rigidez de uma lei processual deve ser mais importante do que uma questão de direito fundamental - a liberdade?

Aqui nos deparamos com as questões de legitimidade e legalidade. Estes juízes claramente assumem uma posição legalista, confirmando a visão positivista sob a qual foram produzidos. Ao assumir este posicionamento ele prefere dar vez à rigidez da lei processual à participar de questões morais, de "liberdade", que foram trazidas por aqueles fatos colocados sob julgamento. No direito Moderno, encontramos claramente defendidas duas posições antagônicas do direito, uma defendendo a legalidade, e a outra a legitimidade. Como legalidade o expresso em lei, o aspecto formal da norma, enquanto que a legitimidade persegue o conteúdo da norma, que deverá ser interpretado o adequando ao fato, à moral, aos bons costumes daquele momento. Wolkmer (1994) apud Moreira (2008: 2), esclarece as duas concepções:

WOLKMER assinala que "a legalidade reflete fundamentalmente o acatamento a uma estrutura normativa posta, vigente e positiva", e que a legitimidade "incide na esfera da consensualidade dos ideais, dos fundamentos, das crenças, dos valores e dos princípios ideológicos". Sua aplicação envolve, como concepção 
do direito, "a transposição da simples detenção do poder e a conformidade do justo advogados pela coletividade".

Temos operando nestes julgamentos a legalidade em oposição à legitimidade, confirmando nossa tese de que as decisões judiciais não são neutras, e assim não devem ser, ademais quando amparadas na visão da legalidade imposta. Estes discursos não podem percorrer a lógica da aplicação da norma ao caso concreto, devendo esta norma abarcar todo e qualquer "pedaço de vida". Ao contrário, e a ratificar o posicionamento moderno do direito, estas decisões devem ser legítimas, devem se adequar aos fatos diante delas colocados, a fim de se alcançe o justo, o moralmente aceito e praticado. E para que este juiz, enunciador assim proceda, inevitavelmente ele construirá discursos em constante diálogo com as posições ideológicas para o qual concorrem, deixando evidente que todo discurso, sobretudo os discursos judiciais, são fruto de um processo interpretativo do juiz, mas que vai além da interpretação, ele participa com sua visão de mundo, intuição, carga axiológica, outras vozes processuais, todos em constante diálogo, constituindo, ao final, um discurso marcado por diversos outros, por diferentes vozes sociais ${ }^{11}$.

O juiz em D11S inicia somente apresentando as partes e já anuncia seu veredicto, que, pelo padrão do gênero, deveria vir na útlima parte. Logo na quinta linha já diz: “ julgo nullo todo o processo...", e a partir do enunciado performartivo, vai enumerando suas fundamentações, trazendo, inclusive, por intermédio de um discurso em modalização segunda, ensinamentos doutrinários, no trecho: "Como ensina..." (F40V 110). Corroborando com

\footnotetext{
${ }^{11}$ Ao pesquisar sobre a vida deste juiz enunciador da D9S, Doutor Manoel Rodrigues Jardim, obtemos informações somente sobre seu pai, José Rodrigues Jardim, que foi uma pessoa renomada, militar e grande proprietário rural. Segundo dados do arquivo do Senado Federal ${ }^{12}$, seu pai era um ativista político, exercendo vários mandatos, dentre eles de Vereador em 1821, Presidente de Província, 1831 a 1837 e Senador, 1837 a 1837 e 1838 a 1841. Chegou a receber também uma homenagem ao ser nomeado, por decreto imperial, Comendador da Ordem de Cristo (05/08/1841). Estamos diante de uma pessoa de família tradicional, pai militar, político e possuidor de terras. Cumpre observar que não obtivemos êxito na procura de informações sobre os outros juízes e seus familiares.
} 
sua citação, ao final de sua narração, enfatiza que seu julgamento está sendo balizado pelos respectivos doutrinadores: " Ora, diante desta doutrina que, fundado nas authoridades de Almeida e Sousa, Mello Freire..." (F41V L5), e retoma o enunciado performativo, com o " Julgando como julgado tenho..." (F41V L14). Ou seja, este juiz também não julgou o mérito da causa, não tocou na questão da liberdade, simplesmente considerou que o processo deveria ser considerado nulo tendo em vista a falta de citação do Réu, que não compareceu em audiência.

Agora, conveniente analisar esta última sentença de uma forma um pouco diferente da análise que vínhamos fazendo: vamos tecer comparações entre esta e a D1S1. Por alguns motivos: a D1S possui o mesmo objeto que a D13S - pedido de liberdade; e os autores estão na mesma condição - foram batizados como livres e encontravam-se vivendo como escravos. Relembrando, D1S trata-se daquela sentença na qual o juiz, apesar de trazer muitos mais argumentos, muito contundentes, inclusive com a voz de autoridade de doutrina e jurisprudência, ao final, ele produz uma decisão desfavorável ao autor, e mais, sem qualquer fundamento coerente e orientado pela lei.

Vamos traçar um panorama, relacionando os argumentos de cada parte. Primeiro da $D 1 S:$

- autor alega ter sido batizado como livre, apresenta assento de nascimento comprovando; traz a voz da jurisprudência - "que em questões desta natureza o escravo pode intentar nova demanda à favor de sua liberdade até mesmo quando tivesse decisão contrária em grau de revista..."; a ação anterior intentada pelo Réu para submetê-lo à escravidão foi julgada procedente porque o escravo, naquela ação réu, não tinha defensor nomeado, ou seja, não pode se defender; na época, sua possuidora era menor, mas mesmo assim o libertou, sendo permitido tal ação conforme doutrina - " menor púbere pode sem autorização de seu tutor libertar seu escravo quando para isso haja justa causa"; e que apesar de 
menor de vinte e um anos, tinha mais de doze, podendo o libertar, e que, neste caso, não pode o juiz reduzir o autor à condição de escravo.

- o réu alega que o escravo era filho de Luisa, escrava dada em pagamento à legítima paterna de sua mulher, Dona Maria Marcondes; foi sempre criado como escravo; que foi batizado como escravo, embora seu assento o considere livre; que Dona Maria Marcondes, sua esposa, na época era menor sujeita à tutela; que o autor não pode fundar sua pretensão em título nulo - porque a certidão de batismo tinha sido anulada em outra ação.

- o juiz fundamenta sua decisão no fato de Dona Maria Marcondes ser menor quando o libertou; que como orfã não poderia dispor de seus bens sem autorização do tutor; mesmo considerando a validade do batismo, o assento foi posteriormente considerado nulo; e enfim, sem qualquer outra justificativa e embasamento legal, julga o autor carecedor da ação ${ }^{13}$.

\section{Sentença D13S:}

- autor pretende provar que fora batizado como livre e em tal qualidade sempre havido; apresenta certidão batismo - folhas 3 - e livro de livres da paróquia; testemunhas corroboram com o alegado.

- impugna a pretensão o réu Padre Antonio levantando suspeita sobre documento do batismo, dizendo que ele foi feito erroneamente pelo Sacerdote da paróquia; que o autor nasceu como escravo e como tal sempre havido; que o autor foi descrito como escravo nos bens de sua senhora, nos autos do inventário, tendo sido somente a mãe do autor declarada livre no testamento, e a prole advinda escrava.

\footnotetext{
${ }^{13} \mathrm{~A}$ carência de ação é definida quando não há a possibilidade jurídica do pedido, legitimidade de partes e interesse processual, conforme determina o art. 267, VI do CPC: Art. 267. Extingue-se o processo, sem resolução de mérito: Vl - quando não concorrer qualquer das condições da ação, como a possibilidade jurídica, a legitimidade das partes e o interesse processual. Assim, deve ser alegada pelo réu em preliminar de contestação a carência de ação, que ocasionará a extinção do processo. Trata-se, portanto, de defesa processual peremptória, pois o feito apresenta um vício que impossibilita o magistrado de analisar o conteúdo do direito, ou seja, o mérito da causa. (Perguntas e Respostas. Disponível em http://www.jurisway.org.br/v2/pergunta.asp?idmodelo=5978. Acesso em 20.05.2012)
} 
- o juiz fundamenta sua decisão nos seguintes argumentos: a certidão de batismo de folhas 3 por si só basta para o intento, e traz a voz da doutrina reforçando este posicionamento, mesmo que o assento não tivesse sido lançado no livro dos livres da paróquia traz uma outra decisão neste mesmo sentido; a força probante deste documento não foi elidida, porque aqueles que impugnam a liberdade devem provar, ou seja, o ônus da prova recaem sobre eles, no caso, o réu - traz a voz da lei e da jurisprudência para salientar seu argumento (enfatiza trazendo a voz da lei como princípio consagrado e em voz direta); o réu alegou o vício do assento de batismo, mas não provou, inclusive abandonou esta alegação no decorrer dos autos; em nenhum momento se contestou o fato do autor ter nascido escravo, como de fato nasceu, mas sim liberto do batismo em diante; o réu trouxe título de compra e venda feita ultimamente - do escravo-; o fato do escravo ter sido lançado no inventário dentre os bens não o coloca nesta condição, aliás, era exatamente contra esse injusto captiveiro que contendia; o testamento na verdade nada disse sobre o autor porque para a testamenteira, na época da feitura do testamento (1859), o autor já encontrava-se na condição de livre (nascera e fora batizado em 1854); mesmo que o documento de folhas 3 e as testemunhas não comprovassem a condição do autor, aí estaria a presunção de direito natural e positivo que lhe assistia, cujo efeito é remover para o Réu o ônus da prova - traz a voz a lei para autorizar este posicionamento - e o réu nada provou; ainda que a condição fosse duvidosa, prevalece " a salutar proteção que desde tempos remotos as nossas leis hão recomendado em favor da liberdade, ao ponto de em seu benefício serem outorgados muitas cousas contra as regras geraes de direito... e até serem tidas em mais consideração as razoes que houver á favor da liberdade do que as que podem fazer justo o captiveiro...isto mormente no caso sujeito onde falece prova concludente... o que também era consagrado já no direito Romano..." (F70R L10).

Como já vimos nos quadros acima, nas duas sentenças muitas vozes foram trazidas para 
compor as decisões. E, se estabelecêssemos "pesos" para estas vozes, podemos perceber que o juiz as manejará conforme o seu intento final, conforme sua "intuição lhe direcione, lhe encaminhe para a decisão que entende mais justa ${ }^{14}$. Comparando os dois julgamentos, vemos que, no primeiro, o autor Benedito também tinha sido batizado como livre, tal como o autor Antonio. A diferença é que a certidão de batismo do Benedito tinha sido anulada, mas em um processo que correrra à revelia dele, ou seja, como não tinha um curador, não pudera se defender adequadamente. E a seu favor traz a voz da lei que permite que o escravo ingresse com uma nova ação quando a decisão tenha sido contra a liberdade. Isto nos leva a concluir que este documento que havia sido anulado poderia ser rediscutido. Mas, mesmo assim, o juiz desta causa a julga com base e tão somente nesta anulação, ou seja, julga o autor carecedor da ação, concluindo que ele não poderia ter ingressado com a ação porque não tinha documento comprobatório para o pedido. Ao passarmos para a causa do Antonio, como dito, sua certidão não tinha sido anulada, mas mesmo assim, ainda que fosse, segundo as argumentações do juiz desta decisão, conforme a lei, doutrina e jurisprudência, mesmo que a certidão de batismo não conseguisse provar a condição de livre, estaria aí a presunção de direito natural que lhe assistira, cabendo ao réu provar que o autor era escravo. " Ademais, ainda que duvidosa fosse a condição do autor, vir lhe hia em socorro - a salutar proteção que desde tempos remotos as nossas leis hão recomendado em favor da liberdade, ao ponto de em seu beneficio serem outorgados muitas cousas contra as regras geraes de direito... e até serem tidas em mais consideração as razoes que houver á favor da liberdade do que as que podem fazer justo o captiveiro... isto mormente quando falece prova contundente". (grifo nosso)

Cabe, neste momento, voltarmos a uma das justificativas deste estudo, apresentada

\footnotetext{
${ }^{14} \mathrm{O}$ juiz com uma função criadora, se valendo de um complexo de valorações particulares sobre o caso concreto, na busca do justo, do razoável.
} 
na Introdução, retomando as palavras lá expressas: "Não raro quando me deparava com decisões totalmente inesperadas, indissociadas daquelas proferidas pela maioria dos juízes daquele tribunal, ou seja, contrária à posição majoritária e despreendida de qualquer justificativa aceitável e coerente, demonstrando, sensivelmente, a ocorrência de outras razões motivadoras, que não a mera aplicação da lei ao litígio. Este fato incitou-me a procurar explicações extrajurídicas para estes julgados divergentes, quando deveriam ser iguais, se a lei fosse simplesmente aplicada ao caso concreto". Não estaremos aqui perante uma situação similar àquelas por mim vivenciadas no exercício da advocacia? Não estaria a sentença D1S respondendo à questão norteadora deste trabalho, comprovando que na produção do discurso decisório, os representantes do Estado (juízes e desembargadores), no processo de interpretação da norma abstrata, para solução do caso concreto, ao produzirem decisões imparciais, refletem discursos totalmente influenciados e permeados por outros discursos, discursos estes representativos das outras vozes que comporão conjuntamente estes discursos dialógicos, denunciando assim o comprometimento ideológico deste juiz enunciador ? A lei não foi somente aplicada, como ato mecânico, tendo o fato se adequando à norma, porque, se assim fosse, estas decisões não poderiam ser diferentes, ambos os escravos Benedito e Antonio, deveriam ter sido considerados livres, e não somente Antonio, visto que, conforme "preceitos legais", doutrina e jurisprudência, em situações duvidosas, em que faltem provas concludentes, a lei "há recomendado em favor da liberdade, ao ponto de se decidir contra, até mesmo, as regras gerais do direito, a ponto de serem levadas mais em consideração as razões que houver em favor da liberdade do que as que podem fazer justo o cativeiro". Percebemos, então, que, cada juiz enunciador criará a sua fundamentação, manobrando a norma conforme seus instintos, visões e ideologias que perseguem, fazendo deste ato de julgar um processo de adequação da norma aos fatos, realizando, assim, uma 
atividade criadora, a fim de que seus fundamentos concorram para o convencimento de sua decisão.

Cumpre salientar que, tendo em vista as análises em busca das estratégias linguísticas que denunciassem o jogo de vozes regido pelo juízes, autores de seus discursos, e, comprovado então, com as mesmas, a utilização de tais recursos e, por consequência, o inerente discurso dialógico que se instaura em todas as fases da decisão judicial, até mesmo naquelas em que se espera uma simples narração, sem qualquer emissão de posicionamento, nos permitimos, nesta última decisão, um salto para a interpretação, em busca direta dos sentidos produzidos, ao passo que as estratégias saltam à vista como foram utilizadas.

Só nos resta concluir, após as análises, que a presença de outras vozes no discurso sentencial lançou-se evidente. Podemos afirmar que nem o discurso judicial, que emana de um representante de um poder Estatal, que por isso deve ser o mais imparcial possível, não está incólume aos discursos dos "outros". E estes "outros" são representados por outras peças processuais, produzidas por outros autores (outros gêneros e discursos), por testemunhas, doutrinas, jurisprudências, intuição, valores, formação, conviç̧ões sociais, culturais e religiosas.

As vozes dos outros são facilmente ouvidas, como demonstramos. E os juízes-autores o fazem principalmente, por intermédio do discurso indireto, direto, em modalização segunda, dentro do discurso narrativo. E, quando da utilização deste recurso, também não o fazem de maneira desinteressada, neutra. São discursos pensados, são vozes escolhidas, como mais representativas e mais bem confirmantes de suas fundamentações e, por consequência, de sua decisão final. Observamos, por exemplo, este fato quando o juiz da D3S, que produz um discurso em favor da Autora, dá muito mais vezes voz a mesma. E isto ocorrerá em todas as partes da sentença, em todas as vozes escolhidas. Cada juiz-autor contará com as vozes (leis, julgamentos, depoimentos de testemunhas, livros, Institutos 
etc.) que lhe forem mais convenientes e que lhe melhor servirem ao intento final. Tanto a sentença que concede a liberdade à escrava Emiliana, a Antonio Leite, quanto a que nega a liberdade ao escravo Guerino, a Benedito, a José, são discursos construídos dentro desta cadeia dialógica de enunciados, de constantes relações com os OUTROS discursos, outras vozes.

Assim, o juiz de D3S, que concedeu a liberdade à parda Emiliana se baseou em um discurso abolicionista, voz dos abolicionistas, quando disse que "Considerando que nossas leis, desde tempos remotos, hão recomendado tudo a favor da liberdade..." (F33R L15), " (...) que mais fortes saõ e de maior consideraçao as razoẽs que há a favor da liberdade do que as que podem fazer justo o captiveiro" (F33R L18) "(...) que sempre que a interpretação é duvidosa, deve decidir-se em favor da liberdade..." (F33R L22)

De forma contrária decidiu o juiz de D5S, que, com um veredicto improcedente, negou a liberdade ao autor José Africano, trazendo a voz escravocrata. Tratava-se de um processo em que pairava a dúvida acerca da idade do escravo, e na dúvida, diferentemente do juiz de D3S, decidiu a favor da escravidão. E para balisar sua decisão, trouxe a voz dos Tribunais Superiores: "Considerando os Arestos dos Tribunais Superiores em questões identicas, em as quais se tem exigido provas explícitas, claras e evidentes - de serem vítimas do comércio illicito de escravos..." (F42R L16) " (...) provas estas consideradas essenciais, como ainda há pouco decidira o Juiz Marechal da 2a Vara..." (F42R L22).

Frisamos que se tratam de julgamentos do mesmo período histórico, sob a vigência das mesmas leis. Um período em que predominava o paradigma positivista, em que a lei era soberana, e que ao magistrado cabia apenas a mera aplicação dos preceitos legais ao caso concreto, da forma mecânica e automática, não dando lugar a nenhum nível de interpretação por parte desses julgadores. Entretando, apenas com a análise das sentenças, já podemos avistar que o que se desejava dos aplicadores do direito era irrealizável. Nos 
casos em tela, os autores da ação encontravam-se na mesma condição, como escravos, e pediam o mesmo: a liberdade. Entretanto, os juízes-autores dos discursos produziram discursos diferentes porque deram voz a "outros" diversos, e porque, como resta óbvio, apesar de serem representantes da vontade Estatal, seus discursos não passam ilesos de suas convicções pessoais, suas visões de mundo e convicções.

Tudo a evidenciar os pensamentos trazidos por Luis Recaséns Siches sobre a lógica do Razoável, como uma razão impregnada com pontos de vista estimativos, critérios de valorização, de pautas axilológicas, trazendo ensinamentos de sua própria experiência e a de próximo, através da história (TOMASZEWSKI, 2005: 4). E também retomando Prado (2010), ao trazer os pensamentos de Jerome Frank, pertencente à escola do Realismo Americano:

O aspecto importante na sentença, embora não o único é a personalidade do juiz, sobre a qual influem educação geral, a educação jurídica, os valores, os vínculos familiares e pessoais, a posição econômica e social, a experiência política e jurídica, a filiação e opinião política, os traços intelectuais e temperamentais.(...) (PRADO, 2010: 21)

A filosofia jurídica, em enlace perfeito com a filosofia da linguagem bakhtiniana, para a qual o objeto do discurso do falante, seja esse objeto qual for, não se torna, pela primeira vez objeto do discurso em um dado enunciado, e um dado falante não é o primeiro a falar sobre ele. (...) O falante não é um Adão, e por isso o próprio objeto do seu discurso se torna inevitavelmente um palco de encontro com opiniões de interlocutores imediatos (...) ou com pontos de vista, visões do mundo, correntes, teorias, etc. (BAKHTIN, 2010:300). 


\subsubsection{Em busca do sentido: os acórdãos}

Com um formato mais peculiar, mas com a gênese da formação da sentença, os acórdãos possuem em sua estrutura a parte do RELATÓRIO, no qual o juiz-relator exporá, em forma resumida, os principais acontecimentos do processo e argumentações das partes, de forma a prepará-lo para ser julgado. Este RELATÓRIO, que na sentença faz parte de uma mesma peça, ou seja, se formaliza no mesmo documento, no ACÓRDÃo o RELATÓRIO se constitui de peça apartada, que será coletivizada com os outros dois juízes que farão parte do julgamento.

Neste relatório, a priori, tal como na sentença, não haverá qualquer tipo de fundamentação, apenas a exposição dos acontecimentos, para que, baseados nestes fatos, os juízes deem o provimento final. E estes juízes expressarão ciência a este RELATÓRIO por meio dos votos, que possuem dizeres padronizados, tais como: "Conformo-me com o relatório". A fundamentação, tal como aparece nas SENTENÇAS, quando necessária (nos casos de voto vencido ou quando a decisão for contrária ou baseada em fundamentos diversos daqueles levantados na SENTENÇA), virá na parte da DECISÃO. Quando dispensada, esta DECISÃO será bem suscinta, dando ênfase à declaração fatal de "nego provimento" ou "dou provimento".

Iniciaremos analisando o D2A, acórdão proferido em virtude do recurso interposto em face da decisão da sentença D1S. Recuperando, esta sentença é aquela na qual o juiz fundamenta sua decisão no fato do assento de batismo ter sido considerado nulo e tão somente por isso, sem qualquer outra justificativa e embasamento legal, julga o autor carecedor da ação. Passemos então a verificar a decisão do Tribunal, que como vimos, partirá de um relatório, a ser feito por um único desembargador, e sobre o qual os outros desembargadores se pautarão para votarem e proferirem a decisão. E trata-se de um caso peculiar, porque teremos dois acórdãos sobre a mesma causa, ou seja, em uma primeira 
decisão dos desembargadores convertem a decisão em diligência, ou seja, optam por não decidir naquele momento, para que seja dada nova possibidade para o Curador do autorapelante se manifestar. Já em uma segunda decisão, depois de um novo relatório, os desembargadores reformam a decisão da sentença que havia julgado pela carência da ação, dando a liberdade ao escravo. Os dois relatórios foram feitos pelo mesmo desembargador, Luis Barbosa Accioli de Brito.

Atendo-nos, então, aos seus dois relatórios, assistimos à utilização de recursos linguísticos diversos para marcarem a presença das outras vozes, autor, réu, legislação, a sentença de primeiro grau. No primeiro relatório, o desembargador, para trazer a voz do autor, utiliza-se do verbo dicendi "alegar", mais a conjunção "que", passando, a partir daí, a trazer por meio do discurso indireto e da narração as fundamentações do autor. Traz vários fundamentos, que se estendem por mais seis períodos narrativos. Inclusive, quando vai narrar o último argumento por ele trazido, por intermédio da citação de sua voz, traz a voz da doutrina que foi citada pelo autor, que o trouxe pelo discurso em modalização segunda, quando diz: " ...que era menor mas pubere a dita sua senhora tendo direito de libertal-o pela (Nov) 119 capítulo 2º," (F77R L13). Resumindo os argumentos do autor trazidos pelo juiz: que o libertando foi libertado no batistério e conservou-se por muito tempo em goso de sua liberdadade; junta assento de batismo e alforria assinada pela dita senhora; no entanto, quando do casamento da senhora com o réu, o mesmo tratou de anular tais títulos, conseguindo sentença favorável, por ter corrido o feito à revelia; ${ }^{15}$ que também sua alforria foi paga por seu protetor, e que sua senhora era menor, mas púbere, tendo o direito de libertá-lo, conforme a lei.

Continuando o seu relatório, o juiz apresenta os argumentos do réu, dando voz a ela

\footnotetext{
${ }^{15}$ Revelia é a situação na qual o réu, quando citado, não responde, não se defende - neste caso o curador não tinha sido nomeado e, portanto, não tinha podido defender o réu (naquele processo, o escravo) e tampouco recorrer da decisão que anulara os documentos.
} 
por intermédio do verbo dizer e discurso indireto, narrando três argumentos do mesmo, dentre eles que o referido assento de batismo não seria verdadeiro; que sua mulher, senhora do escravo, nesse tempo era orfã e tutelada, não valendo seus atos sem o consenso do juiz e tutor. Ademais o assento de batismo tinha sido revogado em virtude de uma sentença passada em julgado. Finaliza o desembargador, trazendo a voz do curador, que havia replicado por negação e a voz da sentença que havia julgado o libertando carecedor da ação e mandado restitui-lo ao seu senhor, como sabemos. Como a decisão não foi prolatada neste momento, passemos a análise do segundo relatório, produzido pelo mesmo desembargador. E ele principia este documento trazendo as alegações do Curador nomeado, já em decisão anterior tinha sido determinado a nomeação e o pronunciamento de um novo Curador ao autor-apelante. Também com a utilização de discurso indireto e o verbo alegar, ele expõe os argumentos do Curador e dentre eles dá voz à doutrina, utilizada pelo autor para embasar sua alegação. Pauta-se o curador na validade da certidão de batismo, e por sua vez na desconsideração do julgamento que o anulou, porque " não prevalece contra a liberdade, maxime faltando defesa, e nem mesmo um curador para appellar; - a incapacidade da pubere não é absoluta para os actos que practica, e naõ a predudicaõ, ficando apenas sujeitos a rescisaõ pelo beneficio da restituiçaõ... e contra esse beneficio a liberdade é irrevogavel." (F90R L6 a L17)

Introduz os argumentos do réu com o verbo "responder" mais "que", trazendo à tona três períodos argumentativos do mesmo, em suma, que o libertando nasceu escravo, que não houve ato legítimo válido pelo qual o libertando pudesse sair desta condição e que o libertando não pudera comprovar a sua venda ao seu protetor. Tal como já explicado, os pronunciamentos que se seguem são os votos dos outros desembargadores, que, após lerem o relatório, dão o voto de "Conformo-me com o relatório" ou não. Neste caso, após todos os votos de conformidade, prolatam a decisão que foi contrária à sentença, ou seja, 
a reformou. Por isso, foi uma decisão fundamentada. Seguindo as coerções do gênero, a decisão inicia com "Accordaõ em Relação...relatados e discutidos estes autos na forma da lei", e então vem a decisão, que diferentemente das sentenças, nas quais o julgamento era monocrático, ou seja, feito por um único juiz, nos Tribunais a decisão virá de um consenso de trê juízes. Assim, vemos o "Reformão a sentença", no plural, mas aqui na terceira pessoa do plural, diferente da sentença que vinha em primeira pessoa, "julgo". Estamos diante também de um ato performativo, que enuncia e aciona, simultaneamente. E o julgamento é pautado na validade dos documentos de batismo e alforria do libertando, considerando que a alforriante era sim capaz, já tinha dezenove anos e autorizada pela mãe, sendo capaz e civilmente responsável pelos seus atos. Ademais, alega-se uma posse da liberdade desde o batismo, contra a qual não se prova, bem como e mais contundentemente: o direito mais favorece a causa da liberdade do que o interesse da menor pubere, não importando o processo que julgou nula a certidão, porque o libertando não tinha tido um curador nomeado. A análise comparativa mostrou que as sentenças D1S e D13S decidiam sobre casos idênticos mas que as decisões tinham sido diferentes, apesar das leis que os pautavam. Agora assistimos então a mais uma decisão, a confirmar o entendimento da D13S, inclusive utilizando-se do mesmo argumento crucial: que o direito mais favorece a liberdade. Por que estas divergências de pronunciamentos? Tudo nos leva a nossa tese inicial, de que os discursos decisórios não são atos puramente mecânicos, de mera aplicação da lei. São muito mais, o juiz é participante ativo deste momento, que é interpretativo, busca-se um sentido para aquela norma que fora criada em abstrato, agora então conectada com a prática e com aquela prática, mais precisamente, daquele caso, daquele processo, daquelas particularidades, com aquelas partes, e fundamentalmente, com aquele julgador, como uma pessoa, um humano, que vive em sociedade, que tem seus pontos de vista e posições ideológicas. 
Em D4A, o juiz-relator inicia apresentando as partes, tomando a autora como "Emiliana, parda" (F50V L1) e o réu como seu "suposto senhor" (F50V L2), seguindo com a informação de que as fundamentações da Autora serão transcritas baseadas nos "documentos e considerações que expande em suas petições de folhas 3 e 25" (F50V L6). Ou seja, já anuncia este autor-criador deste documento que será porta voz de outras vozes, neste caso, a voz da Autora. Consequentemente, passa a narrar, de forma detalhada e com a utilização, inclusive de discurso direto - "Bem assim lhe dou (à sua sobrinha beneficiada) o serviço da escrava Jacinta por espaço de 23 annos (F50V L15), e se neste tempo tiver alguns fihos, sejaõ escravos da doada, e à maẽ dá-se a liberdade."- de um trecho do testamento utilizado como prova, entretanto de uma parte considerada fundamental e contundente para a decisão da causa. Mas ressalta-se, este discurso direto havia sido trazido pela Autora, mas que neste momento, por intermédio do juiz, foi trazida à tona, como um discurso citado dentro de outro discurso citado, a voz do documento, trazida pelo autor, que por sua vez foi trazida agora pelo juiz-autor de seu discurso. Explicita vários argumentos para a voz da Autora, gastando em média seis períodos para a exposição, utilizando-se também de discurso em modalização segunda, quando se refere às folhas dos autos pelas quais estão o documento original -que conferiu a liberdade à Emiliana. (F50V L13). Ainda dentro das estratégias para trazer a voz da Autora, o juiz utiliza-se novamente de um discurso em modalidade segunda: "segundo os documentos que aprezenta..." (F51R L6), se pautando, mais uma vez, nos documentos que considerou incisivos para a decisão. Outro recurso utilizado também no discurso narrativo foi dar ênfase a certos enunciados, grifando-os. Mesmo estando ainda na parte da exposição das alegações das partes, ele, de forma intencional, enfatiza os pontos que acredita fundamental na alegação, e pelos quais ele também fundamentará a sua decisão. (F50V L26, F51R L14). Ao contrário, e claro, de forma intencional, diz em apenas três períodos, quais foram as alegações do réu. A 
decisão será de improvimento, ou seja, confirmará a sentença, e favoravelmente votou o juiz-relator. Está clara então sua escolha de argumentos em favor da Autora.

Ainda nesta peça do RELATÓRIO, o juiz-relator trará para compor o seu discurso a voz do juiz de direito proferidor da sentença, informando qual foi sua decisão naquela oportunidade e sob quais fundamentos: “...deo o Juis de direito a sua sentença, julgando procedente e provada a acçaõ proposta, pelas consideraçoẽs que a fundamentaõ..." (F51V L18). Prossegue relatando o ritual que seguiu o processso depois desta sentença, até a chegada dele ao Tribunal.

A DECISÃO, que fechará a composição deste ACÓRDÃO, foi bem suscinta e objetiva. Como confirmou as razões da sentença recorrida, não trouxe nenhuma fundamentação nova. Apenas representa o consenso dos juízes sobre o relatório e sobre a decisão que já fora dada em primeira instância, na sentença. Constitui-se na parte do acórdão mais sujeita às limitações do gênero, com as expressões padrões e termos jurídicos. Como também já frisado, traz o enunciado performativo que anuncia a decide, declara e aciona, ao mesmo tempo, transformando ou mantendo a realidade fática até então discutida. Entretanto, mesmo nas expressões padrões, resta nítido o chamamento de outras vozes, quando baseiam a decisão "conforme á Direito e ao que consta dos autos" (F52R L7). Tudo o que consta nos autos, todas as alegações, provas, depoimentos, tudo foi buscado, para, neste momento, compor em conjunto o voto final. Até mesmo num dos mais altos grau de jurisdição, partindo de um órgão colegiado, em que três juízes decidem juntos, ainda assim o convencimento não se abstém do diálogo com outros discursos (as fundamentações do juiz da sentença), o discurso, do RELATÓRIO À DECISÃO demonstra contundentemente a cadeia de enunciados que se forma nesta esfera jurídica.

Em D6A, da mesma forma que em D4A, o juiz-relator também irá, inicialmente, apresentar as partes e dizer porque vieram pedir a tutela jurisdicional. O autor é reconhecido 
como "o pardo José" e o réu como "o possuidor do preto, Luis Antonio da Silva". Diferentemente, ele apresentará primeiro o autor, seguindo com os suas razões, e depois o réu, com suas alegações. Pelo autor, coloca que, por intermédio de seu curador, fundou o direito deste à restituição de sua liberdade no fato de ter sido importando para o País depois da promulgação da lei que proibiu o tráfico da escravatura, juntando, para tanto, certidão de propriedade e que sua idade era de 42 anos. Até então verificamos um discurso narrativo, mas que mesmo não sendo de forma marcada, citada, traz o discurso do autor, principalmente quando refere-se à mesma lei por ele transcrita. Em seguida, traz de forma ainda mais reduzida, com apenas um argumento: " contestou o defensor do Reo a pretençaõ daquele, negando a realidade do feito, em que baseara." (F64V L21). A partir de então, a estrutura deste acórdão é mais complexa, ao passo que o juiz vai construindo o percurso de todas as fases do processo, de todas as manifestações das partes, e assume como fio condutor os depoimentos das testemunhas e os comentários do curador do autor e advogado do réu sobre estes depoimentos. Por intermédio da estratégia do discurso indireto, o juiz-relator vai expondo as falas das testemunhas, com o verbo introdutor declarar, mais a conjunção "que": ... "declaraõ as testemunhas...que"... (F64R L29), colacionando mais quatro informações por elas levantadas. Nas outras informações, o verbo declarar vem implícito, sendo expresso somente a conjunção. Cabe aqui buscarmos o significado do verbo utilizado: tornar público, oralmente ou por escrito, qualquer coisa ainda oculta; anunciar(se), revelar(-se), manifestar(-se). (HOUAISS \& VILLAR) ${ }^{16}$. Então, as testemunhas do autor vieram em juízo revelar algo, que pode ser verdadeiro ou falso. Já para inserir as vozes das testemunhas do réu, utiliza-se do verbo afirmar: "affirmarão por sua vez as testemunhas do Reo que..." (F65R L9). Pesquisando o significado de afirmar temos: tornar(-se) ou fazer(-se) firme; estabelecer(-se), fixar(-se), consolidar(-se). 2 - declarar com firmeza;

${ }^{16}$ Disponível em http://houaiss.uol.com.br/busca.jhtm. Acesso em 19.05.2012 
dizer (algo) assumindo o caráter de verdade do que é dito; sustentar, asseverar.(HOUAISS

\& VILLAR $)^{17}$ Desnecessário comentar, somente pelos significados já inferimos a intenção do juiz-relator, quando utilizou-se destes verbos diferentemente, quando sabemos que a decisão final será favorável ao Réu. Desta forma, temos aqui o juiz-relator dando voz às testemunhas, na medida em que baseou-se nos depoimentos que o juiz da sentença julgou, e com base nestes mesmos fundamentos este órgão colegiado também decidirá.

Percebemos então como este juiz-relator vai compondo o seu discurso, direcionado a convencer os juízes adjuntos (que decidirão com base em seu relatório) a compatilharem de sua opinião - a falta de comprovação testemunhal sobre a idade e época em que o autorapelante fora importado, implicando a continuidade de sua situação como escravo (contra a liberdade). Reforça este posicionamento ao escolher, como disse, os depoimentos como fio condutor, escolhendo, por exemplo, os trechos destes depoimentos que compartilhavam de seu posicionamento: “...declaraõ as testemunhas do Autor - apelante:= que sabiaõ, que elle é africano, - que ignoravaõ a epocha em que teria sido importado..." (F65R L1), grifo nosso. Ainda, acrescenta nesta esteira que o curador do Autor-apelante "fes grande cabedal do argumento tirado da idade de seu cliente..." (F65R L21). Ora, fez questão de frisar que toda a causa girou em torno da comprovação da idade pelas testemunhas ou documentos, tanto é que o próprio autor fez grande utilização deste ponto controvertido, entretanto, como demonstrou pelas escolhas dos trechos dos depoimentos, não atingiu o intento o autor, fazendo então confirmar a tese deste juiz-relator e por consequências dos juízes adjuntos.

Ao final, como também fez o juiz-relator de D4A, este relator trouxe a voz do magistrado de primeira instância, proferidor da sentença que julgou o autor carecedor da ação,

${ }^{17}$ Disponível em http://houaiss.uol.com.br/busca.jhtm. Acesso em 19.05.2012 
por intermédio do discurso indireto, novamente retomando o fio condutor da decisão, escolhendo dentre as várias razões expostas por aquele juiz-autor daquele discurso sentencial, o argumento do depoimento testemunhal: “...proferio esse Magistrado sentença, em a qual julgou o autor carecedor da acçaõ, entre outras rasoẽs, - por entender, que as testemunhas produsidas naõ tinhaõ precisado datas certas e positivas, e apenas haviaõ firmado seus depoimentos em simples calculos e conjecturas..." (F65V L13), grifo nosso. Curioso notar aqui que o juiz, diferentemente dos outros relatórios já vistos, faz questão de explicitar que apesar de ter sido o réu vencedor na demanda em primeira instância, mesmo assim foi condenado ao pagamento das custas, especificando a lei, o artigo e o regimento.

Ainda, observamos neste discurso relatorial que, ao final, a confirmar o diálogo que existe do autor do discurso com suas convicções, ideologias, posicionamentos políticos, neste caso, se escravocrata ou a favor da liberdade, o juiz-relator coloca a seguinte observação: "Resta por último observar: - que impugnando o Reo a pretensaõ do Autor, naõ exhibio o titulo de sua propriedade, - escritura de compra, ou formal de partilha."Apesar do réu não ter exibido prova contundente para comprovação de seu direito de propriedade sobre o escravo, ainda assim este escravo não tinha direito à liberdade. Na decisão D3S - da parda Emiliana, a sentença foi clara ao dizer que na falta de prova explícita da escravidão, deve-se decidir em favor da liberdade. Por que aqui, quando também, como foi dito pelo próprio juiz-relator, não fora exibido esta prova explícita, ou seja, a dúvida existia, não se decidiu em favor da liberdade? Porque este juiz-relator já tinha sua convicção formada, seu posicionamento a respeito da escravidão! Onde está então o processo mecânico de mera aplicação da lei, processo este isento de qualquer juízo de valor? Mais uma vez concluimos que as vozes são convocadas de acordo com o sentido que o juiz quer atribuir, confirmando a construção dialógica destes discursos decisórios. 
A peça da DECISÃO se apresenta igualmente a D4A, de forma concisa e direta; confirma os fundamentos da sentença apelada, lançando mão do discurso em modalização segunda: "pelos seos fundamentos (conformes) o direito e às provas dos autos" (F68R L6) trazendo, de forma a validar o todo exposto, o posicionamento assumido, a voz do juiz da sentença, a voz do direito e a voz das provas (testemunhas) dos autos, como argumentos de autoridade a constituir a cadeia dialógica deste discurso. O enunciado performativo assumido pelo verbo confirmaõ, expressa o julgaô, porque o ato de confirmar a sentença recorrida perfaz o ato de julgar o recurso, proferir nova decisão.

O acórdão D8A decide sobre um recurso de apelação advindo de uma decisão desfavorável ao escravo. Aqui temos no polo ativo da ação cinco escravos, Guerino, Antonio, Benedicto, Porcina, Rosa e João. Como perderam a ação em primeira instância são, neste momento, apelantes e parte deles a intenção de reforma da decisão. Desta forma, na peça relatorial, o juiz traz os argumentos destes apelantes por intermédio do discurso indireto, o verbo alegar e a conjunção: “...allegando nas petiçoẽs de folhas...que” (F91R L6). Nesta voz do autor, traz o juiz a voz da senhora dos escravos, a falecida Dona Theodora, acrescentando seus dizeres com o verbo dizer e a conjunção que, narrando, por conseguinte, o que supostamente ela dizia, em vida, sobre a situação destes escravos. Podemos dizer que o verbo utilizado aqui foi o dizer, porque, como também ressaltado pelo juiz, estas palavras foram somente ditas, verbalmente, como uma intenção que "nao pôde ser levar a effeito porque logo depois adoeceu e falleceu" (F91R L18).

Para dar voz aos réus, que aqui também eram mais de um, constituiam-se dos herdeiros da falecida, o juiz também usará o discurso indireto, como verbo introdutor alegar, e colacionará as fundamentações, que se concentram na questão de partilha, de pagamento de credores, que não poderiam ser prejudicados diante de uma mera intenção da falecida, não provada pelas testemunhas, mas mesmo que tivesse sido, ainda se distanciaria da realidade 
fática: "e que admitindo-se mesmo que, aquela finada pretendesse favorecer seos escravos, não serve isto de fundamento para a presente acçaõ, porque da intençaõ a realidade muito dista" (F91V L 16). Todos estes argumentos colocados pelo discurso indireto, ficando o verbo alegar implícito nos demais enunciados. Parte então o relator para dar voz ao juiz da sentença, ao dizer que o mesmo tinha julgado improcedente porque não provada a intenção da liberdade pelos autores. Podemos perceber a constante relação que se estabelece entre os fundamentos da parte que vencerá a demanda com aqueles que o juiz escolhe para compor a sua fundamentação final, ou seja, o juiz aqui enfatizou a mera intenção que teve a falecida, depois separou da alegações dos réus também os enunciados que compartilhavam da questão da intenção, que já nas alegações destes não tinham sido provadas, deu voz também à sentença primeira no tocante justamente a falta de provas da intenção e, por fim, decide, de forma já aguardada, pela confirmação desta primeira sentença. E como em todos os outros documentos, na parte da DECISÃO, serão utilizados os ditames padrões do gênero: "Accordaõ em Relaçaõ, que negam provimento a apellação... por ser ela conforme a direito e as provas dos Autos" (F92R L 10).

\subsubsection{Acórdãos D10A e D12A}

Quando da análise das decisões D9S e D11S, fizemos um comparativo com os acórdãos D10A e D12A. Mas, para retomar, lembramos que o acórdão D10A é aquele que confirma uma sentença que não julga o mérito, mas o processo nulo, por entender que aquela não era a ação competente para o pedido que se havia feito - a liberdade. O Tribunal, então, de forma objetiva na parte da DECISÃO, diz que "confirmaõ a sentença appellada de folhas... que annullou o presente processo, por seos fundamentos e mais ainda, porque a simples justificaçaõ que lhe serviu de base, naõ é o processo da acção da liberdade, que se deveria ter intentado..." (F117V L6). Com um discurso em modalização segunda, 
traz a voz da lei, artigo 80 do Regulamento 13 de Novembro de 1872 dentre outros (mais três regulamentos) para embasar e dar força a decisão, que assim seria proferida "sob o prisma da legalidade". Percorrendo o RELATÓRIO, ainda da D10A, verificamos as mesmas estratégias já correntemente utilizadas pelos outros juízes, dando voz ao apelante e ao apelado, à lei, a outros julgamentos, nos momentos e com as estratégias mais convenientes, a lhes servirem para construção dos discursos dialógicos.

Paremos mais detidamente para verificar o acórdão D12A, que reformou a sentença D11S, aquela que julgou nulo o processo e não se ateve ao pedido principal de liberdade. Compartilhando das nossas observações iniciais, dos nossos primeiros julgados, vemos que neste o juiz-relator também gastou muito mais enunciados com a voz dos autores-apelantes. Ele ficou da linha 5 do F54R a linha 5 do F55R, ou seja, foram três fólios somente para trazer a voz dos autores, narrando, de forma gradativa, todos os seus argumentos. Em seguida, de forma bem resumida, somente se refere à citação do Réu e as páginas em que falou, indo diretamente à voz do Juiz de Direito da sentença que julgou o processo nulo (F55R L7). Esta é a composição surpreendente deste relatório, que, também de forma inusitada, proferirá uma decisão que reformará a sentença e mais, irá para o mérito e dará a liberdade aos autores-apelantes. O "reformaõ a sentença..." (F55V L8) como praxe, por intermédio de um enunciado performativo, em terceira pessoa do plural, para legitimar a voz de um Tribunal e não daqueles julgadores específicos, de forma a se distanciarem do discurso. Porque trata-se de uma decisão que reforma a primeira, ela vem justificada, justificativa esta apoiada nos depoimentos testemunhais, que se apresentavam nos autos, da mesma forma que a outra decisão (que comentamos) também poderia ter feito. Apoiam-se também na lei, a voz de autoridade, inquestionável, a legitimar o veredicto transformador de vidas: outorgador da liberdade. 


\subsubsection{Acórdão D14A}

O recurso julgado por este acórdão advém de uma decisão, ao nosso ver, emocionante, se não uma das mais emocioantes. E, felizmente, ele virá confirmar esta sentença, mantendo o autor em liberdade. O que desperta um interesse maior aqui é a questão do réu ser um padre, e a causa girar em torno da discussão sobre a validade ou não de um assento de batismo, feito por um sacerdote. E mais, em suas alegações este réu (padre) põe em cheque a validade do assento ao dizer que houve erro do sacerdote da paróquia. O réu também parece forjar títulos de compra e venda do escravo, para dizer que o havia comprado e que por isso ele não poderia ser livre. Examinando a estrutura e as estratégias do documento, veremos que, nos parágrafos iniciais o juiz-relator narrará os principais atos do processo, citação, apresentação de defesa, inquisição de testemunhas etc. Depois, já na linha 25 do F97R, ele começa a expor os argumentos das partes, a começar pelo Autorapelado, cedendo voz a ele com o verbo "allegar", na forma de um disccurso indireto, enumerando todos os fundamentos, de 1 a 3 , vindo todos de forma indireta, como verbo apelar implícito. Da mesma maneira, narra os argumentos do Réu, enumerando-os. Outro diferencial, neste relatório, é a citação do pronunciamento do Procurador da Corôa, que em todos os processos deveria se manifestar. Neste caso, sua voz é dada por intermédio do discurso indireto, verbo pedir, e os dizeres são: “...pedio que se fizesse Justiça...”. (F98V L20) Como a DECISÃO será confirmatória da sentença, ela virá com os ditames e recursos de praxe: utilização enunciado performativo e chamamento de tudo o que consta nos autos - “...negaõ provimento a appellaçaõ e confirmaõ a sentença appellada, porque seos fundamentos saõ procedentes e conformes com o que consta dos autos...”. (F99R L5)

Depois desta análise, pudemos constatar que os acórdãos, apesar de sofrerem mais as coerções do gênero, principalmente no que tange a parte das DECISÕES, com dizeres padrões, com o mínimo de justificativa e fundamentações, ainda assim percebemos que, 
dentro destes limites, é possível detectar estratégias linguísticas que denunciam o cruzamento de discursos e a tentativa de validar, em nome da lei e das expressões jurídicas, a decisão que está sendo proferida.

Já a parte do RELATÓRIO, como vimos, muito semelhante aos relatórios das sentenças, deixam emergir diversificadas estratégias, a denunciar o constante diálogo deste juiz enunciador, que neste momento terá também como interlocutor, além das partes, que aguardam a decisão, os outros juízes-desembargadores, que aderirão ou não ao seu relatório. Portanto, para obter este compartilhamento, este juiz construirá enunciados diferentes para cada situação singular, pautado pelo que ele, juiz-relator, acredita e espera como correto, como justo para aquela situação fática, confirmando, mais uma vez, que estes partirão de atos interpretativos da lei ${ }^{18}$ para produzirem discursos integralmente dialógicos.

18"Realmente o juiz decide por intuição e não por uma inferência ou silogismo dos que se estudam na lógica; decide por uma certeza que se forma de modo direto e naõ em virtude de um raciocínio[...]" (SICHES, apud PRADO, 2010: 18). 


\section{Capítulo 6}

\section{Considerações finais}

Neste trabalho, uma grande questão norteou todos os estudos realizados, desde a apreensão linguística dos documentos, com suas transcrições e edições, passando pelo levantamento teórico, reconstituição histórica política, social e econômica e filosófica, chegando até a análise das quatorze decisões: na produção do discurso decisório, os representantes do Estado (juízes e desembargadores), no processo de interpretação da norma abstrata, para solução do caso concreto, produzem discursos imparciais, pautados exclusivamente na lei, refletindo um processo mecânico de mera aplicação ou estes discursos, mesmo constituindo decisões imparciais, poderão refletir discursos influenciados e permeados por outros discursos, discursos estes representativos das outras vozes que comporão conjuntamente estes discursos dialógicos, denunciando assim o comprometimento ideológico do juiz enunciador?

Esta questão partiu da práxis da nossa vivência profissional como advogada, indicando, assim, de antemão, que obrigatoriamente, a teoria a referenciar as análises teria de ser uma teoria filosófica. E a escolha por um teórico da linguagem também se deu em virtude, mais uma vez, da práxis: dos nossos estudos na Academia de Letras. Por conseguinte, a conexão com a filosofia do Direito foi inquestionável, visto a sintonia entre ambas e a intrínseca relação linguagem e Direito. Com isto, estabelecemos então os lugares de onde falararíamos, e para onde apontaríamos. Restava, desse modo, partir para o trabalho. 
Após pesquisas no Arquivo Geral do Estado de São Paulo, estabelecemos o nosso corpus. Ademais, precisamos selecionar o maior número possível de decisões, para que a pesquisa pudesse contribuir para o outro fim a que se destinava: trazer à tona documentos jurídicos do século XIX, transcrevê-los e reproduzi-los, possibilitando diversos estudos futuros, em diversos níveis, ao mesmo tempo que estaríamos contribuindo para sua perpetuação e conservação.

O corpus constituiu-se, então, de sete sentenças judiciais e sete acórdãos, versantes sobre a situação jurídica de negros escravos. Foram decisões manuscritas proferidas na segunda metade do século XIX, anos de 1873-1878, período de pré-vigência da Lei Áurea. Por este motivo, utilizamo-nos da via filológica como meio, em sua função transcendente, para leitura e edição destes documentos, e da teoria/análise dialógica do discurso, a fim de realizar um estudo mais aprofundado da linguagem jurídica e de sua manifestação nas decisões judiciais, contextualizando-se historicamente os discursos abordados, revelando características do Direito daquela época e da situação do escravo na sociedade.

Como segunda etapa, encontramos a leitura destes quatorze documentos, que totalizaram cerca de cinquenta fólios. Todos foram transcritos por intermédio de edições semidiplomáticas, a fim de que conservássemos ao máximo a sua linguagem, desenvolvendo-se somente as abreviaturas. Um estudo da escrita da época, num comparativo com a califrafia dos punhos de cada documento, foi tarefa essencial para a decodificação, em muitos momentos, de números, datas, nomes, citações de leis etc.

Após este trabalho, o corpus estava então pronto para ser destrinchado. Deparamonos, por conseguinte, com um terceiro desafio: o estabelecimento de categorias de análise. Para isto, resolvemos olhar diretamente o corpus, sentença por sentença, acórdão por acórdão. Ele que nos daria, após o estudo dos campos semânticos e sintáticos, as marcas das articulações enunciativas a caracterizar os discursos e a denunciar as vozes aí instaladas. 
A seguir, partindo do estabelecimento destes documentos como gêneros do discurso, a análise fluiu, induzindo-nos a buscar e reconstituir o contexto em que se deram as decisões, estabelecendo um diálogo com estes discursos, buscando em suas esferas de produção, circulação e recepção as relações dialógicas estabelecidas, chegando-se, enfim, ao sentido produzido por estes textos.

Fizemos, no primeiro capítulo, uma retomada da estrutura e do funcionamento do Poder Judiciário Brasileiro no século XIX, ou seja, de toda a organização judiciária dentro da qual as decisões foram produzidas. Constatamos que a estrutura que vigorava havia sido trasladada integralmente da Metrópole. O marco da autonomia jurídica foi a vinda e a instalação da Corte Real, situação que impulsionou, em seguida, a criação de um órgão de alta cúpula no País, representada pela primeira Casa de Suplicação, a terceira instância de julgamento. Nesta esteira, caracterizamos os autores-produtores de nossos discursos, trazendo também aspectos relevantes da dinâmica do estabelecimento destes cargos públicos. No século XIX, os juízes de primeira instância, que proferiam sentenças, eram eleitos pelo povo, dentre aqueles mais bem vistos e quistos na região em que residiam. Os juízes da Relação, que prolatavam os acórdãos, ainda que fossem letrados, mantinham relações de favorecimento com a elite Imperial, visto que eram nomeados pelo Imperador.

Seguimos reconstruindo as relações do escravo na sociedade e os movimentos de resistência, para entendermos o que os motivavam a buscar a tutela jurisdicional, momento em que constatamos que a luta pela liberdade teve início desde os primórdios do cativeiro. A disputa entre senhores de engenho, perda da legitimidade da escravidão e a crescente influência do abolicionismo na sociedade combinaram-se e interagiram, temperando as escolhas e os projetos de liberdade dos escravos. Ainda no capítulo, trouxemos as correntesjurídico filosóficas da época, a fim de entendermos os paradigmas que nortearam a produção 
das decisões analisadas. Observamos que, com a ascensão do positivismo jurídico, o Direito fora equiparado à legislação e completamente afastado da filosofia. Tratava-se de um movimento que reconhecia tão somente a "letra fria da lei". Direito seria o que estaria positivado em texto legal, deixando à margem a ética, a moral e os princípios. A relação entre juiz-sentença era concebida como um exercício lógico, formal, de decodificação da lei, crendo-se na neutralidade ideológica do magistrado. Uma lógica tradicional, sem qualquer tipo de carácter valorativo, o raciocínio jurídico reduzido a uma simples aplicação dedutiva da lei ao fato.

Ao contrário, como restou demonstrado, este exercício lógico formal se ateve à teoria. Na prática, as decisões analisadas demonstraram um alto grau interpretativo, um evidente expressar emocional, mesmo que de forma involuntária, buscando o juiz as intuições direcionadas e as outras vozes, a embasar e concretizar a solução justa, ao seu ver, do litígio.

Definimos os gêneros do discurso sentença e acórdão, nos remontando ao século XIX, trazendo as Ordenações Filipinas, promulgadas em 1603 e vigentes no Brasil para regerem o processo civil, e que somente em 1939 assistiu à aprovação e promulgação do primeiro Código Civil Brasileiro, com inúmeras alterações. Nesta oportunidade, apresentamos a estrutura requerida para a formação dos documentos estudados.

Chegamos, então, às teorias informadoras de nossos estudos: a ciência filológia e as concepções de Bakhtin e o Círculo. Entendemos oportuno agora retomar alguns pontos da análise, a fim de ressaltar as especificidades e responder a nossa questão inicial. Fizemos, primeiramente, uma análise para levantamento das outras presenças, nestes documentos, partindo da afirmação de que estes juízes enunciadores, ao construirem seus discursos, se serviam de outras vozes, a compor, dialogicamente, o intento decisório. Pudemos observar que as estratégias linguísticas do discurso direto, indireto e em modalização segunda, em 
um jogo narrativo, foram evidentes e recorrentes, denotando a cadeia discursiva que se forma nestas discursos. Além disso, destacamos também de que maneira estas vozes emergiam a partir das marcas linguísticas utilizadas para introduzi-las. Os verbos dicendi, os modalizadores e outros verbos considerados dicendi, revelaram, principalmente, nas partes dos documentos que se esperava, pelas coerções do gênero, um discurso objetivo, sem qualquer demonstração de intencionalidade, as marcas da subjetividade, do dialogismo evidente.

Depois das constatações linguísticas, chegamos ao ponto crucial: a construção dos sentidos. Os resultados foram surprendentes. No documento D1S assistimos a um juiz conduzir o seu discurso e as vozes conforme o seu intento final: uma decisão desfavorável ao escravo. Para tanto, operou diversas vozes, de relevância, dentro de seu projeto narrativo - trouxe doutrinas, jurisprudências, a lei, argumentos do autor e réu, dando, ênfase, é claro, para aqueles que melhor contribuiriam para o seu desejo de justiça. Em DS3, no RELATÓRIO, que como vimos tem por objetivo expor um breve resumo do processo, o magistrado, apresenta as partes e então parte para exposição sintética das suas alegações. Entretanto, para a autora, dispendeu muito mais linhas, três períodos, fazendo uma exposição mais longa, narrando três argumentos utilizados pela mesma para fundamentar seu pedido de liberdade. Dentro da exposição dos argumentos da autora, o juiz utilizou-se do discurso direto, ao trazer as palavras do doador, presentes no testamento do Padre Agostinho, na tentativa de reproduzir fielmente a fala deste doador, que ao conceder a liberdade à mãe autora, estaria, consequentemente, a libertando. Como visto, é uma fala escolhida pelo juiz e que sustenta toda a sua fundamentação, que baliza sua decisão.

Em D4A verificamos um juiz relator que inicia apresentando as partes, enfatizando a informação de que as fundamentações da autora serão transcritas baseadas nos "documentos e considerações que expende em suas petições". Anuncia este juiz-criador deste 
documento que será porta voz de outras vozes, naquele momento, da autora. E traz mesmo a voz dela, narrando-a em vários períodos. Ao contrário, e claro, de forma intencional, diz em apenas três períodos, quais foram as alegações do réu. A decisão será de improvimento, ou seja, confirmará a sentença, e favoravelmente votou o juiz relator. Está clara então sua escolha de argumentos em favor da Autora.

Da mesma maneira acontecem em todos os outros discursos analisados, cada um na sua singularidade, mas todos dentro desta cadeia de enunciados a compor os discursos ideológicos. Assim se perfaz o discurso decisório. Os enunciados do autor-juiz são enunciados envolvidos por esta cadeia que dialoga, que forma um todo - o todo da sentença. Consequentemente, o discurso jurídico (gênero sentença e acórdãos) serão produtos das diferentes ideologias sociais que compõem o discurso interno da pessoa do juiz. Os escravocratas, por exemplo, produzirão um discurso com este viés, não concedendo a liberdade buscada pelo escravo, da mesma forma os abolicionistas, que comporão um discurso a fim de conceder a liberdade requerida.

Eles refletirão, desta forma, esses outros discursos sociais (e refratará aqueles dissonantes), que influenciam diretamente este discurso da pessoa do juiz, porque, principalmente, já lhe são inerentes, já fazem parte de seu discurso interno e da situação social que envolve esta produção (contexto).

Este diálogo do eu do juiz e de todos os outros que se inserem neste espetáculo criativo, deixam suas marcas neste discurso, ou seja, as sentenças trazem as marcas expressas ou pistas (vozes tácitas) deste encontro de vozes. É o que se pretendeu aqui com este embate linguagem e direito.

Assim, resta claro que, o ato de aplicação da norma ao caso concreto para produzir sua decisão não se constituirá um ato mecânico, de mera aplicação. Estaremos diante de atos interpretativos, de construção de sentidos e discursos dialógicos, tendenciosos, 
totalmente ideológicos. Cada juiz-autor irá utilizar-se dos mecanismos, dos discursos, das vozes que correspondam ao sentido que objetivará produzir. Dentro do universo de discursos e vozes que compõem o todo do processo, este juiz enunciador, em conformidade com suas convicções pessoais, visões de mundo, discurso interno, irá construir as relações dialógicas suficientes para fundamentar seu discurso decisório.

Pelo exposto, tornou-se comprovada nossa pretensão de, com as análises destes discursos judiciais, encontrar as vozes sociais orquestradas pelo locutor-autor-juiz de direito, e, a medida que estas foram sendo detectadas nestes discursos, constatarmos como elas são imprescindíveis para a construção do sentido desejado pelo magistrado. Estas decisões não cumprem o ritual da mera aplicação da lei (norma abstrata) ao caso concreto. Não é este, de fato, o procedimento ocorrido, nas tramas da linguagem jurídica. Não é tão simples e objetivo assim. Considerando todo o expositório teórico sobre a construção do discurso, enunciados, dialogismo, sentidos, não podemos continuar admitindo este processo como um ato mecânico, realizado pelo condutor destes processos judiciais, na consecução dos objetivos estatais de solucionar litígios, o ato de julgar. Esta "pessoa", representante do Estado, ocupa legitimamente a posição de autor de um discurso, que será construído por intermédio de uma linguagem - palavras que não são neutras, mas dialógicas por nascimento.

No calor destas colocações ou assunção de posicionamentos, como ficará então o sentido nas decisões? Ou melhor, como podemos continuar afirmando que a lei é a mesma para todos e que estas decisões refletirão objetivamente o comando legal, resultando em decisões justas e imparciais? É possível uma decisão imparcial, distante e sem qualquer influência do mundo que a circunda?

O simples ato de aplicá-la será direcionado às singularidades (autor, réu...), o que resultará também diferentes realizações, diferentes discursos, diferentes sentidos. Como o juiz (autor-criador) dará voz aos personagens de seu discurso, ou seja, quais os recursos 
utilizados por este autor para trazer ao discurso estas outras vozes? É o que tentamos responder com as análises. 


\section{Capítulo 7}

\section{Referências bibliográficas}

ABRAHÃO, Fernando Antonio. As Ações de Liberdade de Escravos do Tribunal de Campinas. Campinas, SP: UNICAMP, Centro de Memória, 1992.

ALMEIDA, Manoel M. Santiado. Os manuscritos e impressos antigos: a via filológica. In: Elis Almeida Cardoso Caretta; Beatriz Daruj Gil; Valéria Gil Condé. (Org.). Modelos de Análise Linguística. 1 ed. São Paulo: Contexto, 2009, v. 1, p. 224-234.

ALVIM, Arruda. Manual de Direito Processual Civil. Volume 2: processo de conhecimento. 9 ed. São Paulo: Editora Revista dos Tribunais, 2005.

ARQUIVO GERAL DO ESTADO DE SÃO PAULO. Processos do Tribunal de Justiça do Estado de São Paulo.

ATAÍDE, Joanita Mota de. Lista de Verbo Dicendi. São Luís, 1998. Disponível em http://pt.scribd.com/doc/7728214/lista de verbo dicendi. Acesso em 19 de maio de 2012.

AUTHIER - REVUZ, Jacqueline. PALAVRAS INCERTAS: As não coincidências do dizer. Campinas, SP: Editora da Unicamp, 1998.

BAKHTIN, Mikhail M (Voloshínov). Marxismo e filosofia da linguagem: problemas fundamentais do método sociológico na ciência da linguagem. 14 ed. SP: Hucitec, 2010.

BAKHTIN, Mikhail M (Voloshínov). Problemas da Poética de Dostoiévski. 3.ed. Tradução Paulo Bezerra. Rio/São Paulo. Forense Universitária, 2002.

BAKHTIN, Mikhail M (Voloshínov). Os Gêneros do Discurso in Estética da Criação Verbal. 5.ed. Tradução Paulo Bezerra. São Paulo. Editora Martin, 2010. p. 261-305.

BAKHTIN, Mikhail M (Voloshínov). O Autor e a personagem na Atividade Estética. In: Estética da Criação Verbal. 5.ed. Tradução Paulo Bezerra. São Paulo. Editora Martin, 2010. p. 3-90.

BAKHTIN, Mikhail M (Voloshínov). Questões de Literatura e de Estética. A Teoria do Romance. 3.ed. Tradução Paulo Bezerra. São Paulo. Hucitec.(1998[1975]). 
BAKHTIN, Mikhail M (Voloshínov). (1926) Discurso na Vida, Discurso na Arte. Tradução de Carlos Faraco, para fins acadêmicos.

BITTAR, Eduardo Carlos Bianca. Linguagem Jurídica. São Paulo: Saraiva, 2001.

BITTAR, Eduardo C. B.; ALMEIDA, Guilherme A. de. Curso de Filosofia do Direito. São Paulo: Saraiva, 2011.

BORGES, José Ademir Campos. O processo do conhecimento humano e as correntes do pensamento jurídico. Jus Navigandi, Teresina, ano 10, n. 685, 21 maio 2005 . Disponível em: <http://jus.com.br/revista/texto/6751>. Acesso em: 1 de junho de 2012.

BRAIT, Beth. As vozes bakhtinianas e o diálogo inconcluso. In: BARROS, Diana.Luz.Pessoa e FIORIN, José Luíz. (Orgs.). Dialogismo, polifonia e intertextualidade. São Paulo: Edusp (Ensaios de Cultura, 7), 1994. p. 11-28.

BRAIT, Beth. Org. Bakhtin Conceitos-Chave. São Paulo. Contexto, 2008.

BRAIT, Beth. Org. Bakhtin Outros Conceitos-Chave. São Paulo. Contexto, 2010.

BRAIT, Beth. Org. Bakhtin: dialogismo e construção do sentido. São Paulo. EdUnicamp, 2008.

BRAIT, Beth. MELO, Rosineide. Enunciado/ enunciado concreto/ enunciação. in BRAIT, Beth. Org. Bakhtin Outros Conceitos-Chave. São Paulo. Contexto, 2010.

BRANDÃO, Helena H. Nagamine. Introdução à Análise do Discurso. 2.ed. Campinas: Ed. Da Unicamp, 2004.

BRASIL. Biblioteca Virtual do Governo do Estado de São Paulo. Disponível em http://www.bv.sp.gov.br. Acesso em 04 de maio de 2012)

BRASIL. Código Comercial de 1850. Disponível em http://www6.senado.gov.br/ legislacao/ListaPublicacoes . action?id=80659. Acesso em 13 de novembro de 2011.

BRASIL. Código de Processo Penal de 1832. Disponível em http://www.planalto.gov . br/ccivil\_03/Leis/LIM/LIM-29-11-1832.htm. Acesso em 13 de novembro de 2011.

BRASIL. Constituição Federal.Código Civil.Código de Processo Civil. 7 ed. Cahali, Y.S.(org)São Paulo: Revista dos Tribunais, 2005.

BRASIL. Decreto $n^{0} 763$ de 19 de setembro de 1890. Disponível em http://www. jusbrasil.com.br/legislacao/116752/decreto-763-90. Acesso em $1^{\mathrm{O}}$ de junho de 2012.

BRASIL. Decreto $n^{0} 737$ de 25 de novembro de 1850. Disponível em http://www6. senado.gov.br/legislacao/ListaPublicacoes . action?id=80659. Acesso em 13 de novembro de 2011. 
BRASIL. Supremo Tribunal Federal. Glossário Jurídico. Disponível em <http: //www.stf.jus.br/portal/glossario/verVerbete.asp?letra=I \&id=161> Acesso em 3 de maio de 2012 .

BRASIL. Ordenações Filipinas. Disponível em http://www1.ci.uc.pt/ihti/proj八_ lipinas/13p667.htm. Acesso em 13 de novembro de 2011.

BRASIL. Senado Federal. Arquivo. Disponível em http://www.senado.gov.br/ senadores/senadores $\backslash$ biografia . asp? codparl=1976 $\backslash \& l i=3 \backslash \& l \mathrm{cab}=1834-1837 \backslash \& l f=$ 3. Acesso em 21 de maio de 2012.

CAMBRAIA, César Nardelli. Introdução à Crítica Textual. São Paulo: Martins Fontes, 2005.

CAMPOS, Adriana Pereira. Heranças Lusitanas: Direito e Escravidão na América Portuguesa. Revista Justiça \& História, on line. Rio Grande do Sul, 2004, volume 4. Acesso em 12 de junho de 2011.

CERVONI, Jean.A Enunciação.São Paulo, Editora Ática, 1989.

CEZÁRIO, 2010. Disponível em Disponível em http://www.ambito-juridico.com.br/ site/index .php?n\_link=revista \_artigos \_leitura\\&artigo \_id=7088. Acesso em 3 de maio de 2012 .

CUNHA, Dóris de Arruda Carneiro da. Dialogismo em Bakhtin e Lakubinskii. In: Investigações - Lingüistica e Teoria Literária. Recife: UFPE, v. 18, n. 2, p. 103-114, jul. 2005.

FERREIRA, Waldemar Martins. História do Direito Brasileiro, Tomo II. São Paulo: Livraria Freitas Bastos S.A, 1952.

FRAGA FILHO, Walter. Encruzilhadas da Liberdade: histórias de escravos e libertos na Bahia (1870/1910). Campinas, SP: Editora da UNICAMP, 2006.

FREITAS, Ariádne Castilho. A intersubjetividade em sentenças judiciais. Tese de Doutorado em Linguística Aplicada e Estudo da Linguagem. Pontifícia Universidade Católica de São Paulo- PUC-SP, 2008.

GOMES, Sérgio Alves. Os poderes do juiz na direção e na instrução do processo civil. Rio de Janeiro: Forense, 1995.

GRILLO, S. V. C. ; FERRAZ, F. S. M. . A divulgação científica: uma abordagem dialógica do enunciado. In: Elis Almeida Cardoso Caretta; Beatriz Daruj Gil; Valéria Gil Colnde. (Org.). Modelos de análise linguística. 1 ed. São Paulo: Contexto, 2009, v. 1, p. 135-152.

HOUAISS, A. \& VILlAR, M. de S. Dicionário Houaiss da Língua Portuguesa. Disponível em http://houaiss.uol.com.br/busca.jhtm. Acesso em 19 de maio de 2012.

KOCH, Ingedore.Argumentação e linguagem. 8.ed. São Paulo: Cortez, 2002. 
LOPES, José Reinaldo de Lima. O direito na História. Lições Introdutórias. São Paulo: Editora Max Limonad, 2002.

LOPES, P.G.M; RIOS, P. Justiça no Brasil : 200 anos de história. São Paulo: Conjur Editorial, 2009.

MARQUESE, Rafael de Bivar. A dinâmica da escravidão no Brasil. Resistência, tráfico negreiro, alforrias, séculos XVII a XIX. Novos Estudos - CEBRAP $\mathrm{n}^{0}$ 74. São Paulo, Março de 2006.

MARINHO, Maria Celina Novaes. Transmissão do Discurso Alheio e Formas de Dialogismo em Vidas Secas, de Graciliano Ramos in BRAIT, Beth. Org. Bakhtin: dialogismo e construção do sentido. São Paulo: Ed. Unicamp, 2008.

MAUZAISSE, Jean Baptiste. Napoleon Crowned by time, il. Disponível em http: //www.emersonkent.com/historic \_documents/napoleonic \_code \_1804.htm. Acesso em 4 de outubro de 2011.

MEGALE, Heitor. CAMBRAIA, César Nardelli. Filologia Portuguesa no Brasil. DELTA: Documentação de Estudos em Lingüistica Teórica e Aplicada., vol.15. São Paulo, 1999. Disponível em http://www.scielo.br/scielo.php?pid=S0102-44501999000300001\ \&script=sci \_arttext. Acesso em 15 de maio de 2012.

MELO, Gladstone Chaves de Melo. Iniciação à filologia e à linguística portuguesa. 6.ed.rev e melhorada.- Rio de Janeiro: Ao Livro Técnico, 1981.

MELO, Rosineide. Delegacia de Polícia: Defesa da mulher? Um enfoque dialógico. Dissertação de Mestrado Linguística Aplicada e Estudo da Linguagem - Pontifícia Universidade Católica de São Paulo- PUC-SP, 2001.

MELO, Rosineide. Atas: Registro de lutas discursivas da Escola Peixoto Gomide de Itapetininga. Tese de Doutorado em Linguística Aplicada e Estudo da Linguagem - Pontifícia Universidade Católica de São Paulo- PUC-SP, 2006.

MENEZES, Jaci Maria Ferraz. Abolição no Brasil. A construção da liberdade. Revista HISTEDBR on line. Campinas, n.36, p. 83-104, dez.2009. Acesso em 12 de junho de 2011.

MIOTELLO, Vladimir. Ideologia in BRAIT, Beth. Bakhtin: conceitos-Chave. $4^{\mathrm{a}}$ ed. São Paulo: Contexto, 2008.

MOREIRA, Júlio da Silveira. Legalidade e legitimidade. A busca do direito justo. Jus Navigandi, Teresina, ano 13, n. 1887, 31 ago. 2008 . Disponível em: $<$ http://jus.com.br/revista/texto/11651>. Acesso em: 6 de outubro de 2012.

Perguntas e Respostas. Disponível em http://www. jurisway.org.br/v2/pergunta.asp? idmodelo=5978. Acesso em 20 de maio de 2012.

PRADO, Lídia Reis de Almeida.O juiz e a emoção: aspectos da lógica da decisão judicial. $5^{\mathrm{a}}$ ed. Campinas, SP: Millennium Editora, 2010. 
RIBAS, Antonio Joaquim. Consolidação das Leis do Processo Civil. Rio de Janeiro: Jacintho Ribeiro dos Santos Livraria Editora, 1915.

ROMANHOLI, Cintia Patrícia. A heterogeneidade no discurso judicial: procedimentos discursivos. Dissertação(Mestrado em Letras) - Universidade Estadual de Londrina, Londrina, 2008.

SANTIAGO, Emerson. Economia Brasileira no século XIX. Disponível em http: //www.infoescola.com/historia/economia-brasileira-no-seculo-xix/. Acesso em 15 de abril de 2012.

SANTOS, Washington. Dicionário Jurídico Brasileiro. Belo Horizonte, Del Rey, 2001.

SIQUEIRA JUNIOR, Paulo Hamilton. Lições de Introdução ao Direito. São Paulo: Editora Juarez de Oliveira, 2002.

SILVA, Nady Moreira Domingues da. O positivismo no Brasil. In Filosofia em Revista. São Luis, Maranhão: Palestra proferida na Sociedade de Estudos e Atividades Filosóficas, SEAF, 1982.

SOARES, F. S.M. GOMES, H.F. PASSOS, J.R. Documentação Jurídica sobre o negro no Brasil, 1800 a 1888: indice analítico. Salvador, Secretaria da Cultura, DEPAB, 1988.

SUDATTI, Ariani Bueno. Dogmática Jurídica e Ideologia: o Discurso Ambiental sob as vozes de Mikhail Bakhtin. São Paulo: Quartier Latin, 2007.

THEODORO JÚnIOR, Humberto. Curso de Direito Processual Civil - Teoria Geral do direito processual civil e processo de conhecimento. Rio de Janeiro: Forense, 2009.

TEZZA, Cristovão. A construção das vozes no romance. In BRAIT, B. Org. Bakhtin, dialogismo e construção do sentido. Campinas, SP: Editora da Unicamp, 2008.

TOMÁS, Renata Nobre. Efeito Argumentativo dos Verbos Dicendi no Discurso Relatado do Twitter.. Anais do SILEL. Volume 2, Número 2: EDUFU, 2011.

TOMASZEWSKI, Adauto de Almeilda.A lógica do razoável e o negócio jurídico: reflexôes sobre a difícil arte de julgar. Publicado em 16 de agosto de 2005. Disponível em www.mundojuridico.adv.br. Acesso em 17 de maio de 2012.

VOLSHINOV, V.N. La construcción de la enunciación in SILVESTRI, A. e BRANCK, G. (orgs.). Bajtín y Vigotski: La organización semiótica de la consciencia. Barcelona: Anthropos, pp.245-276 (1993[1929]).

VOLSHINOV, V. N. Que és la lenguaje? in SILVESTRI, A. e BRANCK, G.(orgs.). Bajtín y Vigotski: La organización semiótica de la consciencia. Barcelona: Anthropos, pp.217-243. (1993 [1929]).

WOLKMER, Antônio Carlos. Legitimidade e legalidade: uma distinção necessária. In: Revista de Informação Legislativa, n. 124. Brasília, 1994, p. 180. 